BENOMYL RESISTANT MUTANTS OF

\title{
SCHIZOSACCHAROMYCES POMBE
}

COLD SENSITIVE FOR MITOSIS

by

Douglas J. Roy

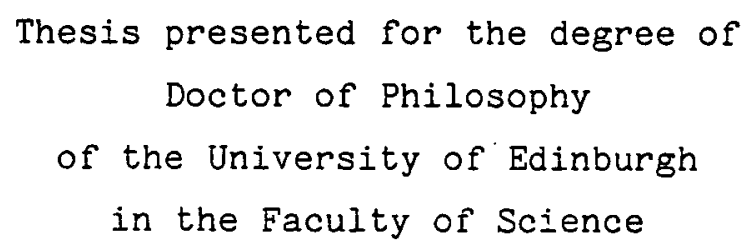

1985

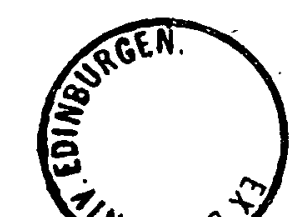


I declare that this thesis was composed by myself, and that the research presented is my own work. Due acknowledgement is made within the text for contributions from other sources. 
For Lorraine. 


\section{Contents}

Page

Summary

List of Abbreviations

Chapter 1 - INTRODUCTION

1.1 The eukaryotic cell cycle

1.2 Properties of microtubules : 4

1.3 Benzimidazole carbamate inhibitors and the 7 selection of tubulin mutations

1.4 Cell cycle mutants

1.5 Project outiine

Chapter 2 - MATERIALS AND METHODS

2.1 Organisms 18

2.2 Media and growth conditions 18

$\begin{array}{lll}2.3 \text { Genetical techniques } & 21\end{array}$

2.4 Physiological techniques 26

2.5 Microscopy 32

2.6 Molecular genetic techniques 38

Chapter 3 - ISOLATION OF BENOMYL RESISTANT COLD SENSITIVE MUTANTS

3.1 Sensitivity of the wild type strain to benomyl 49

3.2 Isolation of benomyl resistant cold sensitive 52 cde mutants

3.3 Identification and classification of cs cde mutants 53 Chapter 4 - GENETICAL CHARACTERISATION

4.1 Introduction 58

4.2 Meiotic segregation analysis of D2, D3 and C10 58

4.3 Reversion analysis of mutant D3 60

$4.4 \mathrm{U} . \mathrm{V}$. induced reversion of mutants D3 and C10 60

4.5 Meiotic segregation analysis of A4, A22, B18, C29, 63 D12, D19, D23 and E14 
Chapter 4 (continued)

$\begin{array}{lll}4.6 & \text { Genetical analysis } & 67\end{array}$

4.7 Meiotic segregation analysis of D1 69

$\begin{array}{lll}4.8 & \text { Mutants C23 and D15 } & 72\end{array}$

4.9 Intercrossing of mutants 73

4.10 Intragenic recombination $\quad 75$

4.11 Linkage analysis of ben 4 to other loci $i 6$

4.12 Dominance relationships 92

4.13 Chromosome allocation of the ben4 locus 95

4.14 Further analysis of benomyl resistant mutants 98

Chapter 5 - PHYSIOLOGICAL CHARACTERISATION

$\begin{array}{lll}5.1 & \text { Introduction } & 108\end{array}$

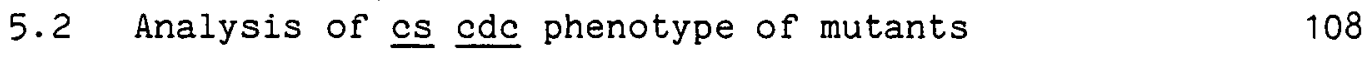

$\begin{array}{lll}5.3 & \text { Analysis of drug resistance spectrum } & 124\end{array}$

5.4 Physiological response of hsR5 and hsR10 to 132 temperature shift

Chapter 6 - CYTOLOGICAL CHARACTERISATION

$\begin{array}{llr}6.1 & \text { Introduction } & 139\end{array}$

6.2 Cytological analysis of ben 4 mutants 140

$\begin{array}{ll}6.3 \text { Giemsa staining } & 141\end{array}$

$\begin{array}{lll}6.4 \text { Acid fuschin staining } & 146\end{array}$

$\begin{array}{lll}6.5 & \text { DAPI and ethidium bromide staining } & 148\end{array}$

6.6 Transmission electron microscopy 152

6.7 Attempted identification of microtubules in $\underline{S}$. pombe 159 with immunofluorescence microscopy

6.8 Cytological analysis of hsR5 cells 162

6.9 Cytological analysis of ben 4 cde double mutants 168 
Chapter 7 - AN APPROACH TOWARDS THE IDENTIFICATION OF THE ben $4^{+}$ GENE PRODUCT

7.1 Introduction

7.2 Attempted complementation of the ben 4 mutant phenotype with plasmid pRB129

7.3 Strategy for subcloning TUB2 into pDB248

7.4 Attempted detection of $\beta$ - tubulin sequences in $\underline{\text { S. pombe }}$

Chapter 8 - DISCUSSION

8. 1 The nature of the mutant phenotype of ben 4 and hsR5 mutants

8. 1a Genetical implications

8.1b Physiological implications

8.1c Cytological implications

8.2 Genetics of tubulin in S. pombe 205

8.3 Tubulin mutations in other organisms 209

8.4 Organisation of tubulin genes and the regulation of 212 tubulin synthesis

8.5 Nature of the ben $4^{+}$product

8.6 Conclusions

Acknowledgements

Bibliography 


\section{ABSTRACT/SUMMARY}

As a means of analysing structural aspects of mitosis, benomyl resistant cold sensitive cde mutants of Schizosaccharomyces pombe have been isolated with the intention of identifying $\beta$ - tubulin mutations. Selection for mutants with this phenotype enriched strongly for mutations at a previously unidentified locus, designated ben 4 . Several ben 4 mutants were the subject of a detailed genetical, physiological and cytological characterisation. By analogy with other systems, the following salient features of these mutants suggested that ben 4 coded for a B-tubulin protein:

(1) The benomyl resistance and cold sensitivity phenotypes were conferred by a mutation in a single nuclear gene.

(2) Physiological analysis indicated that the mutants analysed were specifically defective in mitosis at the restrictive temperature. It was found from cytological analysis that ben 4 mutants arrest with a single aberrant nucleus. This information pointed to the involvement of the ben $4^{+}$product in the mitotic machinery.

(3) Six of the seven ben 4 mutants tested showed increased sensitivity to the antimitotic agent CIPC.

Subsequent studies by other workers have shown that $\underline{s}$. pombe contains two $\alpha$ - and one $\beta$ - tubulin genes, neither of which are allelic to ben4. From this work the possibility that ben 4 represents an undetected tubulin gene seems remote. Attempts to functionally complement the ben 4 mutant phenotype by transformation with a plasmid carrying the $\underline{S}$ cerevisiae $B$ - tubulin gene (TUB2) were unsuccessful. However, by using the TUB2 gene as a hybridization probe, a tentative identification of $\beta$ - tubulin sequences in $\underline{S}$. pombe genomic DNA has been made. 
If not a tubulin, the ben $4^{+}$product would appear to code for a protein which interacts with benomyl and is intimately involved in the mechanism of mitosis. For these and other reasons it is postulated that ben 4 codes for a microtubule associated protein.

A benomyl resistant heat sensitive cdc mutant, designated hs $R 5$, has been isolated and analysed. The phenotypic properties of this mutant, which include mitotic arrest and chromosome condensation, are consistent with a defect in microtubules. 


\section{Abbreviations}

ATP adenosine triphosphate

CAMP cyclic adenosine monophosphate

A $_{595}$ Turbidity (Absorbance) at 595nm

DTT dithiothreitol

DNA deoxyribonucleic acid

RNA ribonucleic acid

mRNA messenger ribonucleic acid

EDTA ethylene diaminotetra acetic acid

Tris tris (hydroxyl) methylamine

MBC

TBZ

See Table 2.1

APM

CIPC

EMM Edinburgh Minimal Medium

YE Yeast extract medium

ME Malt extract medium

YPD Yeast extract/peptone medium

MAP microtubule associated protein

DAPI 4, 6-diamidine-2-phenylindole dihydrochloride. 


\section{Chapter 1}

\section{INTRODUCTION}

\subsection{The eukaryotic cell cycle}

It was Virchow who, in 1855, first recognised that cells proliferate by growth and subsequent division (see Ambrose \& Easty, 1970). From this observation has emerged the concept of the cell cycle. That is, the growth and subsequent division of a single cell into two daughters is accomplished in an ordered series of well defined biochemical and morphological stages, otherwise known as landmark events (Pringle, 1978). The cell cycle of eukaryotes is typically described as a four stage process. A period of time, G1, separates the start of the cycle from DNA synthesis which occurs during $S$ phase. A second period of time, G2, then separates $S$ phase from mitosis, during which chromosome segregation takes place. Cytokinesis, the final separation of daughter cells, is completed shortly after mitosis. It is clear, however, that the duration of each of the stages varies considerably between different cell types (for examples see Mitchison, 1971).

Numerous studies in which the normal cell cycle is perturbed either by inhibitors or by mutants conditionally defective in the process have shown that events required specifically for division (e.g. DNA synthesis, mitosis and cytokinesis) can be uncoupled from general processes of cellular growth. In view of this, cell proliferation has been considered to represent, in simple terms, the product of two sub-cycles: the 'DNA-division cycle' and the 'growth cycle' (Mitchison, 1977).

The major events of the cell cycle, DNA synthesis, mitosis and cytokinesis have each received considerable experimental attention. 
For instance, the biochemical events associated with DNA synthesis are now well understood (see Kornberg, 1980). By contrast, although mitosis has been well described morphologically, little is known of the event biochemically. Crucial to the successful completion of mitosis in all eukaryotic cells is the appearance and functioning of the mitotic spindle, a complex morphological structure which mediates the organisation and separation of daughter chromosomes.

Three aspects of mitosis are currently under intensive investigation. The first of these involves identification and detailed examination of components of the mitotic apparatus. The second is concerned with describing how the various components of the mitotic spindle interact mechanistically with each other to mediate chromosome separation. The third aspect is more broadly based and is concerned with analysing how mitosis is integrated spatially and temporally within the cell cycle. This thesis is concerned primarily with the first of these problems: that is, the identification of structural components of the mitotic apparatus. Our current understanding of the latter two aspects has been reviewed elsewhere: Pickett-Heaps et al. (1982) and Heath (1981) discuss critically various models which have been proposed to account for the mechanism of mitosis; the cell cycle regulation of mitosis is discussed in the volumes of John (1981) and Streiblová and Nurse (1984).

The observations of Inoué and colleagues, which described mitosis in marine oocytes visualised by polarised-light microscopy, provided early experimental evidence that the mitotic spindle was composed of bundles of longitudinally arranged fibres (Inoué, 1953). Changes in the birefringent image of the spindle obtained with this technique strongly suggested that spindle fibres were self-assembled from a 'pool' of subunits, and that the proposed subunits and fibres 
existed in dynamic equilibrium (Inoué \& Sato, 1967).

The introduction of electron microscopy, some years after Inoués initial observations, confirmed that the predominant structural feature of the spindle was a system of long tubular elements, since designated microtubules. Nuclear microtubules are seen to emanate from distinct foci located at each end of the fully formed spindle (for examples see Inoué, 1964; Fuge, 1977). Microtubules have since been identified as ubiquitous components of eukaryotic cells, where they mediate a variety of other functions including cell motility, structural organisation of the cytoplasm, nuclear movement and transport of cytoplasmic organelles (Stebbings \& Hyams, 1979).

It is well established that the mitotic apparatus is a highly labile structure. The treatment of mitotic cells with inhibitors such as colchicine, low temperatures (typically $0-4^{\circ} \mathrm{C}$ ) or hydrostatic pressure, cause disassembly of the structure (Fuge, 1977; Inoué, 1964; Roth, 1967). It is now clear that such treatments disrupt the normal equilibrium existing between subunits and microtubules, favouring the disassembly of microtubules into subunits (Stebbings \& Hyams, 1979). A number of studies have shown that disruption of the spindle during anaphase or telophase stages of mitosis causes a cessation in the poleward movement of chromosomes (Fuge, 1977). These findings clearly demonstrated the crucial importance of microtubules in mitosis, whether simply as organising elements and/or as direct generators or mediators of force required for the process. For this reason, and in preparation for the outline description of the experimental approach adopted in this project, the following sections consider in some detail the structure, function and biochemistry of the major components of the mitotic spindle: microtubules: 


\subsection{Properties of microtubules}

Ultrastructural analysis reveals that microtubules have a diameter of $25 \mathrm{~nm}$ and are constructed from a helical arrangement of 4-5 nm diameter subunits, designated tubulin (see Figure 1.1). The mitotic inhibitor colchicine has played a key role in the structural and functional analysis of microtubules. The antimitotic effect of colchicine (see above) suggested that the drug exerted its action by binding directly to the tubulin subunits of microtubules. Direct evidence for this was provided by Borisy and Taylor (1967a) who showed that radio labelled colchicine bound specifically to a protein of $110,000 \mathrm{M}$ and $6 \mathrm{~S}$ sedimentation coefficient which could be obtained from a wide variety of eukaryotic cells, especially those rich in microtubules. Borisy and Taylor (1967b) also demonstrated that disassembly of mitotic spindles resulted in the accumulation of the 110,00 Mrinding protein. The structural and biochemical evidence presented above suggested strongly that the colchicine binding protein was indeed tubulin.

A detailed description of the biochemistry of microtubule protein has been largely derived from the analysis of microtubules obtained from mammalian neural tissue, a rich source of these elements. Weisenberg (1972) discovered that microtubules could form spontaneously in brain homogenates under certain experimental conditions. The temperature lability of microtubules has been of value in their purification from cell extracts. Microtubules may be purified from other cellular components by passage through cycles of temperaturedependent assembly and disassembly (e.g. Roobol et al, 1980a). A class of microtubule associated proteins (MAPs), are found to copurify with microtubules isolated in this way. It is clear that MAP proteins are important integral components in many, if not all, microtubule 
systems. The structure and function of MAPs and their relevance to the mitotic spindle is discussed further in Chapter 8. The morphological complexity of the mitotic spindle necessitates that the structure must contain, in addition to tubulin and MAPs, many other components; direct evidence for such components is however limited. A series of reports describe the immunological detection of actin (Sanger, 1975; Herman \& Pollard, 1978), dynein-like ATPase (Pratt et al., 1980) and the $\mathrm{Ca}^{2+}$ binding protein calmodulin (Welsh et al., 1978; Tash et al., 1980) within the mitotic apparatus. Whether or not the techniques employed in these studies allow for the unambiguous detection of these components is a question which has been raised by some authors (for example,Petzelt, 1979). There is also evidence for the association of a $\mathrm{Ca}^{2+}$ activated ATPase with the mitotic spindle (Petzelt, 1979).

The 110,000 $N_{r}$ tubulin subunit is a heterodimer composed of two non-identical polypeptide chains, each one of approximately 55,000 M, and designated $\alpha$ - and $\beta$-tubulin (Luduena, 1979). Both tubulins are acidic, being particularly rich in glutamate and aspartate residues towards the C terminal end of the chain (Ponstingl et al., 1979, 1981). It is considered that this region may well constitute the binding site for cationic components of the spindle such as MAPs (Ponstingl et al., 1981). The tubulin dimer contains a single colchicine binding site as well as bindilung sites for several other antimicrotubule agents including vinblastine and podophyllotoxin (Luduena, 1979). The two vinblastinebinding sites are distinct from the colchicine site, whereas the podophyllotoxin binding site partially overlaps the colchicine site (Luduena, 1979). Also located on the tubulin dimer are two binding sites for guanosine triphosphate (GTP): the exchangeable (E) site and the non-exchangeable (N) site (Jacobs, 1979). GTP 


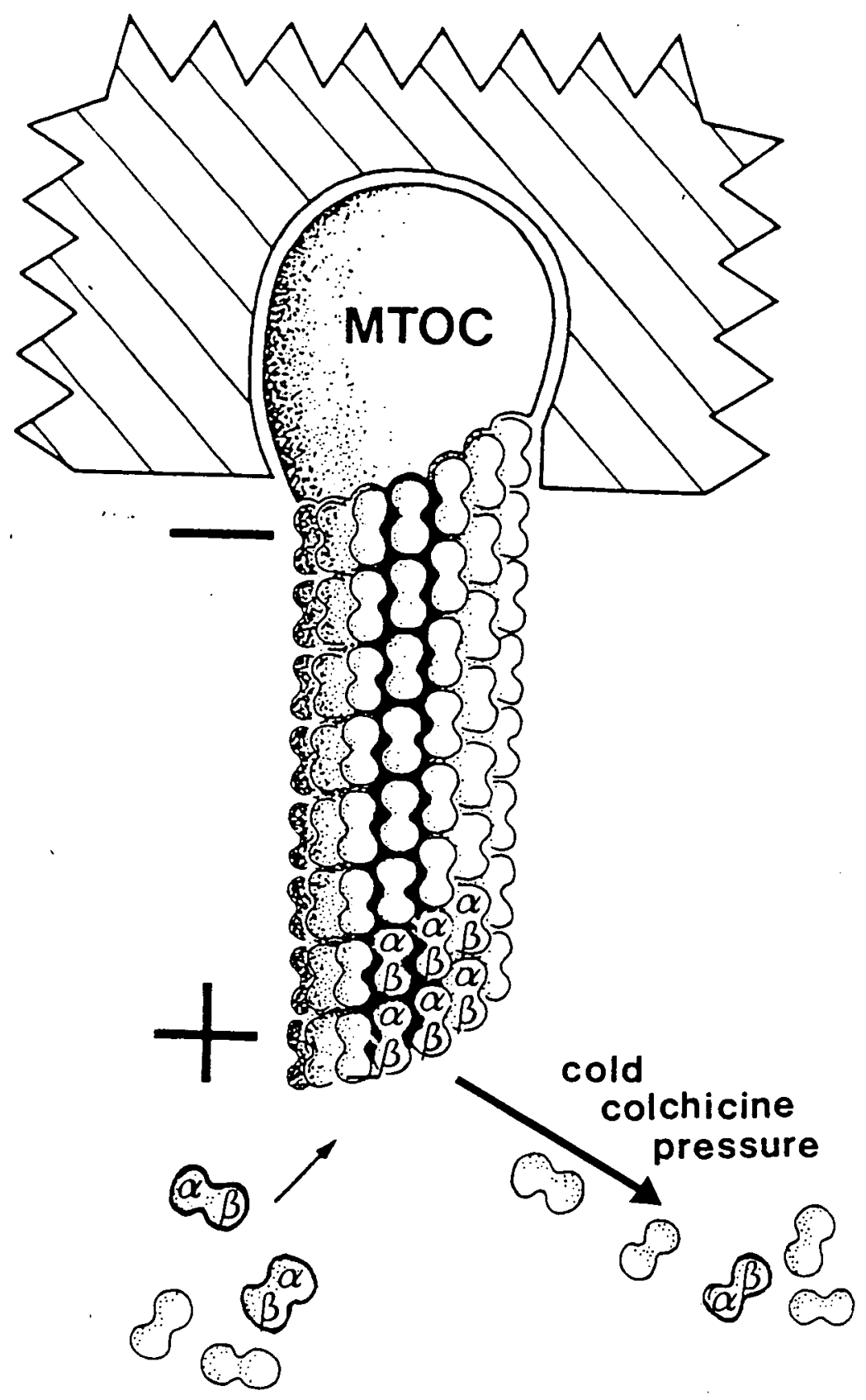

Figure 1.1 Schematic diagram representing the dynamic equilibrium between microtubules and tubulin subunits. Note headto-tail helical arrangement of subunits. MTOC represents the microtubule organising centre, the in viro microtubule nucleating element. 
binds tightly to the $\mathrm{N}$ site but only loosely to the $\mathrm{E}$ site. Spontaneous self-assembly of microtubules occurs at $37^{\circ} \mathrm{C}$ in the presence of GTP and magnesium ions. A high concentration of tubulin is required to initiate assembly, and the concentration of free calcium ions must be reduced since these ions are inhibitory to the process (Weisenberg, 1972). During assembly the GTP bound at the $\mathrm{E}$ site becomes hydrolysed; this is thought to allow conformational changes in the dimer to take place on addition to the microtubule (Jacobs, 1979). The physical properties of the self-assembiy process indicate that hydrophobic interactions play a major role in microtubule formation (Inoué, 1982; Takahashi \& Sato, 1982). As is the case in vivo, microtubules and tubulin subunits exist in vitro in a dynamic equilibrium with each other, in which microtubule disassembly is favoured by treatment with either cold, colchicine or hydrostatic pressure (Inoué, 1982, see also Figure 1.1). It is widely accepted that binding of colchicine to the tubulin dimer in effect reduces the pool of tubulin subunits available for self-assembly, thereby shifting the equilibrium towards net disassembly of microtubules (Figure 1.1).

Direct analysis at the amino acid and nucleotide sequence level has shown the primary structure of $\alpha$ - and $\beta$ - tubulin to be highly conserved throughout evolution (Ponstingl et al., 1979; Ponstingl et al., 1981; Valenzuela et al., 1981; Luduena \& Woodward, 1973). A reasonable assumption is that functionally important domains on the tubulin proteins have been most highly conserved. In support of this is the ability of tubulins from Aspergillus nidulans (Sheir-Neiss et al., 1976); Saccharomyces cerevisiae (Clayton et al., 1979; Baum et al., 1978; Water \& Kleinsmith, 1976) and Physarum polycephalum (Roobol et al., 1980b) to copolymerise with chick or porcine brain tubulin through cyles of assembly and disassembly. Slight differences are, however, apparent 
between tubulins of distantly related organisms. This is exemplified by the differential affinity of tubulins from higher and lower eukaryotes towards various antimicrotubule agents, a topic which is covered further in the following sections.

Utilising probes of cDNA copies of tubulin mRNAs it has been shown that several genes exist for both $\alpha$ - and $\beta$ - tubulins in the majority of eukaryotic organisms examined thus far (Cleveland et al., 1980; Kalfayan \& Wensink, 1981; Silflow \& Rosenbaum, 1981). Biochemical evidence suggests that tubulin microheterogeneity within cells may be widespread taxonomically (Morris, 1980; Bibring et al., 1976; Kemphues et al., 1980). The organisation of tubulin genes and the regulation of tubulin synthesis are discussed further in Chapter 8.

Although colchicine has been of great value in the study of tubulins from higher eukaryotics and flagellated protistans, it has been less useful for the analysis of tubulins from a range of non-flagellated microbial eukaryotes. Physarum polycephalum, Schizosaccharomyces pombe and $\underline{\mathrm{S}}$. cerevisiae are relatively insensitive to colchicine, although the latter two organisms are inhibited by colcemid, a derivative of colchicine (Haber et al, 1972; Lederberg \& Stetten, 1970; Roobol et al., 1980a). The relative insensitivity of these organisms to colchicine has been correlated directly with lowered affinity of the tubulin subunit for the drug, rather than differences in drug permeability or detoxification mechanisms (Haber et al., 1972; Roobol et al., 1980a; Burns, 1973). The relatively small amount of tubulin present in non-flagellated microbial eukaryotes has, until recently, precluded the purification of the protein by self-assembly techniques. However, tubulins from $\underline{S}$. cerevisiae, $\underline{A} \cdot \underline{\text { nidulans }}$ and $\underline{P}$. polycephalum have been identified by co-polymerisation with neural tubulin (Clayton et al., 1979; Sheir-Neiss et al., 1976; Roobol et al., 1980b; Water \& 
Kleinsmith, 1976; Baum et al., 1978). In a significant breakthrough, Roobol et al. (1980a) have recently reported the purification of tubulin from $\underline{P}$. polycephalum by $\underline{\text { in }}$ vitro self-assembly techniques.

\subsection{Benzimidazole carbamate inhibitors and the selection of tubulin mutations}

A group of benzimidazole derivatives have emerged as powerful tools for the analysis of microtubules in lower eukaryotes. Three of the compounds, benomyl, MBC and TBZ (see Figure 2.1 for structure and nomenclature) were originally introduced as systemic fungicides in the late 1960 's and have since become of immense economic importance. Benomyl is effective against most, but not all, fungal genera, but has little effect against higher plant or mammalian cells (Bollen \& Fuchs, 1970). Clemons and Sisler (1969) demonstrated that benomyl breaks down rapidly in aqueous environments to yield the active component $\mathrm{MBC}$. It was originally thought that benomyl and MBC exerted their action through inhibition of DNA and RNA synthesis (Clemons \& Sisler, 1971). Subsequent studies showed that this inhibition was due to a secondary effect resulting from the failure of cells to complete nuclear division (Hammerschlag \& Sisler, 1973). Benomyl, MBC and TBZ have since been shown to act as potent inhibitors of mitosis and other microtubule mediated events in lower eukaryotes (Quinlan et al., 1980; Orr \& Rosenberger, 1976; Oakley \& Morris, 1980; Howard \& Aist, 1980; Hastie, 1970; see also Table 5.2). These studies indicated that the mode of action of benomyl, $M B C$ and $T B Z$ was likely to be very similar to that of colchicine.

A biochemical basis for the action of MBC has been established. Davidse (1975) showed that ${ }^{14} \mathrm{C}$ labelled MBC bound selectively to a protein component of $110,000 \mathrm{mw}$ in cell-free extracts of $\underline{A}$. nidulans 
and certain Penicillium species. In subsequent studies the MBC binding protein was identified as tubulin (Davidse \& Flach, 1977). TBZ has also been shown to bind to fungal tubulin (Davidse \& Flach, 1978). These findings have recently been confirmed: Roobol et al. (1980a) have demonstrated that $M B C$ binds to tubulin of $\underline{P}$. polycephalum and thereby prevents the self-assembly of these subunits in vitro.

Shortly after its commercial introduction, reports appeared of benomyl resistance amongst wild populations of plant pathogenic fungi (Bollen, 1971; Rucklidge, 1977). As a result, studies were conducted to analyse the genetic basis of resistance to these compounds in fungi. Van Tuyl (1974) identified three loci, benA, B and C, which control resistance to benomyl in $\underline{A}$. nidulans. Mutants defective in benA exhibited a high level of resistance to benomyl and most showed cross resistance to TBZ. A proportion of benA mutants, however, exhibited supersensitivity to these compounds (Van Tuyl, 1974).

Davidse (1975) and Davidse and Flach (1977) demonstrated that cell free extracts of certain benA mutants with high level resistance showed little affinity for ${ }^{14} \mathrm{C} M B C$, whereas the affinity for ${ }^{14} \mathrm{C} \mathrm{MBC}$ to a benA mutant with increased sensitivity was much greater than that of the wild type. From these observations, Davidse and Flach (1977) concluded that differential sensitivity of benA mutants to MBC was most probably conferred by different amino acid alterations in the drug binding site of the tubulin dimer.

Morris and his colleagues have tested this hypothesis directly by examination of tubulins from wild type and benA mutants of A. nidulans (Sheir-Neiss et al., 1978). The majority of benA mutants screened exhibited abnormalities in $\beta$ - tubulin protein when analysed by two dimensional gel electrophoresis (Sheir-Neiss et al., 1978; Morris, 1980). The co-expression of normal and abnormal $\beta$ - tubulins in benA/ 
ben $^{+}$heterozygotes ruled out the possibility that the tubulin alterations were the result of post-translational modification (Sheir-Neiss et al., 1978). BenA was therefore identified as a structural gene for B- tubulin in $\underline{A}$. nidulans. Some benA mutants exhibit a heat sensitive phenotype (Morris, 1980). Heat resistant revertants of these benA mutants were sought in the hope that suppression in some cases would be due to conformational alterations in proteins interacting with $B-$ tubulin. A mutation in tubA, a locus distant from benA, was found to suppress the heat sensitive phenotype of strain benA11. Strains carrying the former mutation expressed an electrophoretically altered $\alpha$ tubulin. Further experiments confirmed that tuba represented a structural gene for a $\alpha$-tubulin in this organism (Morris et al., 1979). In support of these studies, a colchicine resistant mutant from a Chinese hamster ovary cell line has recently been shown to harbour electrophoretically abnormal $\beta$ - tubulin (Cabral, 1980 ).

This work elegantly confirmed the hypothesis that resistance to antimicrotubule agents such as MBC or colchicine may be conferred by structural alterations in the molecular target of the drug, namely $\beta-$ tubulin. Tubulin mutations may be selected in other ways: Raff and colleagues have identified a mutation in a testis-specific $\beta$ - tubulin in Drosophila melanogaster through the isolation of sterile-male mutants (Kemphues et al., 1979).

The study of ribosome assembly, the final stages of which are accomplished via the temperature dependent self-assembly of subunits (Dyson, 1974), provides an analogous system to the self-assembly of microtubules. Mutations affecting ribosome assembly in prokaryotes or eukaryotes may be significantly enriched for through the isolation of cold sensitive (S) mutants (Waldron \& Roberts, 1974; Guthrie et al., 1969; Falke \& Wright, 1975). Ribosomes are also target sites for a 
number of metabolic inhibitors such as streptomycin, sparsomycin and linfemycin (Watson, 1977). Resistance to such inhibitors may be conferred by alterations in the structural integrity of the ribosomes. Such alterations may in turn lead to cold sensitive defects in ribosome assembly due to an increased kinetic energy barrier to the self-assembly of subunits (Crouzet \& Begueret, 1978; Singh et al., 1978). It seemed likely that these genetic approaches to the study of ribosome assembly might equally well be adapted to the analysis of microtubule structure and function.

Indeed, this general approach has been utilised by other workers to obtain mutants whose phenotype may be attributed to defects in microtubule related functions. Sato (1976) has described a colchicine resistant mutant of Chlamydomonas reinhardii which also shows a cold sensitive cell division defect. A colchicine resistant Chinese hamster ovary cell mutant which exhibits a cold sensitive $G 1$ arrest has been reported (Ling, 1977). However, the pleitropic phenotype of this mutant has been attributed primarily to an alteration in plasma membrane function. Lederberg and Stetten (1970) have isolated colcemid resistant strains of $\underline{\mathrm{S}}$. pombe, some of which are also pleiotropically inhibited in cell division. The genetic basis of the defects in these mutants has not however been established. Some time after the commencement of this present study, a report appeared which described the genetic basis of resistance to $\mathrm{MBC}$ and $\mathrm{TBZ}$ in $\underline{\mathrm{S}}$. pombe (Yamamoto, 1980). This latter work was also initiated with the intention of isolating tubulin mutations in this organism. In this report it was shown that at least three loci in $\underline{S}$. pombe, ben 1,2 and 3 , control resistance to these compounds (Yamamoto, 1980). However, none of the mutants defective in ben 1,2 or 3 obtained expressed a temperature conditional cde defect (Yamamoto, 1980). This class of mutants is discussed further during the course of this thesis. 


\subsection{Cell cycle mutants}

In recent years a genetical approach has been successfully applied to examine the control and ordering of events within the cell cycle. The DNA-division cycle may be thought of in terms of a regulated process dependent upon the consecutive and/or simultaneous action of a series of genes (Simchen, 1978). It has been possible to identify mutations in genes whose products are required specifically for cell cycle progress by the isolation of mutants specifically defective in the process. Such cell division cycle (cdc) mutants have been isolated almost exclusively as temperature conditional lethals, in which the cell cycle phenotype is expressed at the restrictive (usually higher) temperature. Most cdc mutants have been isolated on the basis of a homogeneous cell cycle arrest phenotype (e.g. Hartwell, 1978) and/or continued growth during the absence of division (e.g. Nurse et al., 1976). It is considered that the majority of cdc lesions represent point mutations, and that transfer to the restrictive temperature results in a conformational alteration and subsequent malfunction of the thermosensitive cdc product (Nurse, $\stackrel{\text { ct }}{\text {, }}$ 1976; Pringle, 1978). Collections of $\underline{c d c}$ mutants defective in various events of the cell cycle have been isolated in a number of cell systems (for review: Simchen, 1978).

This methodology has been particularly useful for the analysis of cell cycle events in microbial eukaryotes, most notably in $\underline{A}$. nidulans (Orr \& Rosenberger, 1976; Morris, 1980) and the yeasts $\underline{\mathrm{S}}$. cerevisiae (Hartwell, 1978) and $\underline{S}$. pombe (Nurse et al., 1976; Nasmyth \& Nurse, 1981).

The behaviour of cdc mutants at the restrictive temperature may yield information as to the nature of the defective gene product. For instance, the transition point exhibited by a particular cde mutant is 
considered to represent the stage in the cell cycle during which the cdc gene product normally completes its function (Nurse et al., 1976; Pringle, 1978).

The terminal phenotype of a cdc mutant is expressed after prolonged incubation at the restrictive temperature and contains morphological, physiological and biochemical characteristics of a cell blocked in division at a particular point in the cycle. This information may be of value in determining the nature of the defective cdc gene product. In addition, information regarding the interdependence of events in the cycle can be obtained by observing which events in the cycle following temperature shift do or do not occur after the initial cdc arrest, (see Pringle \& Hartwell, 1981).

A detailed study of the dependency relationships of events in any one cycle is therefore possible. For instance, in $\underline{s}$. pombe examination of the terminal phenotypes of various cdc mutants has established that cytokinesis is dependent upon the completion of DNA synthesis and mitosis. On the other hand, rounds of mitosis and DNA synthesis may continue in the absence of cytokinesis (Nurse et al., 1976). In addition, analysis of $\mathrm{cdc}^{-}$phenotypes at the ultrastructural level may provide further information about the dependency relationship of various organelles and subcellular structures within the cycle. Indeed, much attention has been focussed on the role of nuclear and cytoplasmic microtubules and their nucleating elements the spindle pole bodies as important controlling elements in the yeast cell cycle (Byers \& Goetsch, 1975; Zickler, 1981). In this respect, cdc mutants are particularly useful since they provide a large number of block points within the cycle. However, little as yet is known of the biochemical identity of $\underline{c d c}$ gene products. Extensive collections of $\underline{c d c}$ mutants defective in mitosis are available, most notably, A. nidulans 
(Morris, 1980), $\underline{\mathrm{S}}$. cerevisiae (Hartwell, 1978) and $\underline{\mathrm{s}}$. pombe (Nurse et al., 1976; Nasmyth \& Nurse, 1981). Although these mutants have been of value in examining morphological aspects of mitosis, they have been of limited value for the identification of structural components of the process. In view of this, the work described in this thesis was undertaken in an attempt to obtain cdc mitotic mutants whose biochemical basis could be unambiguously. established.

\subsection{Project outline}

The preceeding sections described how mutations in $\beta$-tubulin may be obtained by selecting for resistance to antimicrotubule agents. The versatility of cdc mutants for studying processes of the cell cycle was also stressed. These two approaches have been combined in the present study in an attempt to obtain mitotic mutants defective in $\beta$-tubulin.

The fission yeast $\underline{\underline{S}}$. pombe is attractive experimental material for such a study. The organism has been used extensively as a model eukaryote in cell cycle studies (Mitchison, 1977), and has been well characterised genetically (Gutz et al., 1974), physiologically (Mitchison, 1970) and cytologically (McCully \& Robinow, 1971). An extensive collection of cdc mutants blocked in various stages of the cell cycle is available in this organism (Nurse et al., 1976; Nasmyth \& Nurse, 1981). S. pombe, a unicellular organism, has a shortcylindrical morphology in which growth occurs by means of lengthwise extension from the tips of the cell. S phase occurs at the very beginning of the cell cycle, and the majority of the remaining cycle is occupied by the G2 phase (Mitchison, 1977). Mitosis in $\underline{\mathrm{S}}$. pombe, though structurally less complex, is broadly similar to that of higher eukaryotes (McCully \& Robinow, 1971; see also Fig. 8.1): a mitotic 
spindle is a prominant feature of the process, although breakdown of the nuclear membrane, as in other Ascomycetes, does not occur. Benomyl and MBC have been shown to effectively and specifically inhibit mitosis in this organism (Fantes, 1982; Walker, 1982). Cell division is accomplished by the deposition of a centrally located transverse septum (Johnson et al., 19영); the final separation of daughtercells arising from cleavage through this structure.

An outline of the experimental strategy adopted in this project is described in Figure 1.2. The first step involves isolation of benomyl resistant mutants of $\underline{\mathrm{S}}$. pombe. By analogy with the benA mutants of $A$. nidulans it was likely that a proportion of resistant mutants would harbour an altered $\beta$-tubulin.

As described above, microtubule assembly is a cold sensitive process both in vitro and in vivo. With this in mind, it was considered that mutants with an altered $\beta$-tubulin might also exhibit a cold sensitive defect in mitosis due to an increased kinetic energy barrier to microtubule assembly at the low temperature.

Support for this hypothesis is provided by the observations, described above, that mutations affecting ribosome assembly may be enriched through the isolation of drug resistant cold sensitive mutants. Screening of resistant mutants was therefore carried out in order to identify, in the first instance, resistant mutants with a cs cdc defect. Any benomyl resistant cold sensitive cdc mutants obtained would then be subjected to further characterisation to determine more precisely the nature of the cdc defect. 
Wild type $\underline{S}$. pombe cells

$\downarrow$ Mutagenesis (U.V.)

Selection for benomy 1

resistant mutants at $35^{\circ} \mathrm{C}$

Benomyl resis

Replicate to EMM agar at $20^{\circ} \mathrm{C}$

$\downarrow$

Incubation at $20^{\circ} \mathrm{C}$ : identification

of mutants with a cold sensitive (cs)

defect

$\downarrow$

Incubation at $20^{\circ} \mathrm{C}$ : identification

of cs mutants with a cde

phenotype

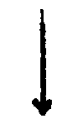

Benomyl resistant cold sensitive

cdc mutants

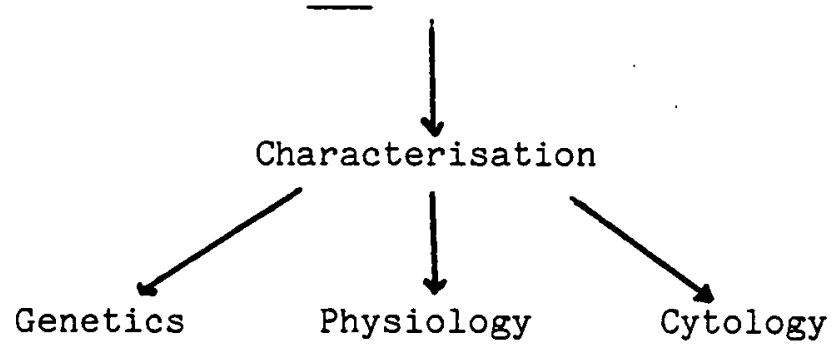

Figure 1.2 Experimental strategy used in the project. 


\section{Chapter 2}

\section{MATERIALS AND METHODS}

\subsection{Organisms \\ 2.1a Yeasts}

The fission yeast Schizosaccharomyces pombe Lindner was used throughout the project. The strains used were the original wild type isolates described by Leupold (1950). The wild type haploid strain 972 with $\underline{h}^{-}$mating type was used for mutant isolation as well as for genetical, physiological and cytological studies. The use of the wild type haploid strain 975 with $\underline{h}^{+}$mating type was reserved for genetical analyses only.

The homothallic diploid strain ( 541 ) of Saccharomyces cerevisiae, used in immunofluorescence studies (Section 6. was obtained from the culture collection of Dr. I. W. Dawes (Microbiology Department, Edinburgh University). The genotype of this strain is given below.

S41: $\frac{\text { MATa }}{\text { MAT } \alpha} \frac{\text { HO }}{\text { HO }} \frac{\text { HML } \alpha}{\text { HML } \alpha} \frac{\text { HMR a }}{\text { HMR a }} \frac{\arg 4.1}{\arg 4.1} \frac{\operatorname{cyhl}}{\operatorname{cyh} 1}$

\section{1b Bacteria}

Bacterial transformations were carried out using Escherichia coli strain JA221 ( $\underline{\text { recA } 1 ~}$ leuB6 trp E5 $^{\text {hsdR }}{ }^{-}$hsdM $^{+}$lacYC600). This strain was also used for the propagation of shuttle vectors.

\subsection{Media and growth conditions}

The procedures described by Gutz et al. (1974) and Mitchison (1970) for the culture and storage of $\underline{\underline{S}}$. pombe strains were followed.

All medium was sterilized before use by autoclaving $\left(120^{\circ} \mathrm{C}\right.$ at $151 \mathrm{bfin}^{-2}$ for 15 minutes). 


\section{2a Yeast growth media}

Strains of $\underline{S}$. pombe were routinely cultured on YEA complex medium (Gutz et al., 1974).

\section{YEA}

$\begin{array}{lc}\text { D-glucose } & 30 \mathrm{gg} \\ \text { Yeast extract (Difco) } & 5 \mathrm{~g} \\ \text { Agar } & 20 . \mathrm{g} \\ \text { Distilled } \mathrm{H}_{2} \mathrm{O} & 1000 \mathrm{ml} .\end{array}$

Agar was omitted in the preparation of liquid YEA. YEA was supplemented with adenine at $75 \mathrm{mg} / 1$ in order to culture cells carrying the ade 6.704 mutation.

For the characterisation of certain strains the YPD complex medium described by Yamamoto (1980) was used.

$\underline{\text { YPD }}$

$\begin{array}{ll}\text { D-glucose } & 20 . \mathrm{g} \\ \text { Yeast extract (Difco) } & 10 \cdot \mathrm{g} \\ \text { Peptone (Difco) } & 20 \cdot \mathrm{g} \\ \text { Agar } & 10 \cdot \mathrm{g} \\ \text { Distilled } \mathrm{H}_{2} \mathrm{O} & 1000 \mathrm{ml} .\end{array}$

The defined medium $\operatorname{EM}(2)$ (Mitchison, 1970), as modified by Nurse (1975), was used for mutant isolation as well as in genetical and physiological analyses. This medium is referred to simply as EMM in this thesis.

\section{$\operatorname{EMM(2)}$}

$\begin{array}{lc}\text { Potassium phthalate } & 3.0 \mathrm{~g} \\ \mathrm{Na}_{2} \mathrm{HPO}_{4} \text { (anh.) } & 1.8 \mathrm{~g} \\ \mathrm{NH}_{4} \mathrm{Cl} & 5.0 \mathrm{~g} \\ \text { D-glucose } & 20.0 \mathrm{~g} \\ \text { Salts } & 20.0 \mathrm{ml} . \\ \text { Vitamins } & 1.0 \mathrm{ml} . \\ \text { Trace minerals } & 0.1 \mathrm{ml} . \\ \text { Distilled } \mathrm{H}_{2} \mathrm{O} & 1000 \mathrm{ml} . \\ \text { 1N KOH } & 1.0 \mathrm{ml} . \\ \text { Agar (Difco) } & 20.0 \mathrm{~g} .\end{array}$


Agar and $\mathrm{KOH}$ were omitted in the preparation of liquid EMM. The composition of the salts, vitamins, and trace element solutions were as described by Mitchison (1970). All growth supplements (amino acids, adenine and uracil) were added to EMM, as required, at a final concentration of $75 \mathrm{mg} / 1$. The dye magdala red (Phloxin $B$, Sigma) when added to YEA or EMM agar aids the detection of colonies containing a high proportion of dead cells (Kohli et al., 1977). Magdala red was added to $\operatorname{cool}\left(60^{\circ} \mathrm{C}\right)$, autoclaved agar at a final concentration of $20 \mu \mathrm{g} / \mathrm{ml}$.

MEA, a nitrogen limiting medium, was used for the mating and sporulation of strains in genetical analyses.

$\underline{\text { MEA }}$

$\begin{array}{ll}\text { Malt extract (Difco) } & 30 \mathrm{~g} \\ \text { Agar } & 20 \mathrm{gg} \\ \text { Distilled } \mathrm{H}_{2} \mathrm{O} & 1000 \mathrm{ml} .\end{array}$

\section{$2.2 b$ Bacterial growth media}

Luria-Bertani (LB) medium was used for the culture of $\underline{E}$. coli .

$\underline{L B}$

$\begin{array}{lc}\text { Tryptone (Oxoid) } & 10 . \mathrm{g} \\ \mathrm{NaCl} & 10 . \mathrm{g} \\ \text { Yeast extract (Difco) } & 5 \cdot \mathrm{g} \\ \text { D-glucose } & 1 \mathrm{~g} \\ \text { Agar } & 15 \mathrm{~g} \\ \text { Distilled } \mathrm{H}_{2} \mathrm{O} & 1000 \mathrm{ml} .\end{array}$

Agar was omitted in the preparation of liquid LB medium. Bacterial transformants were selected on LB agar containing either ampicillin or tetracycline at 100 or $15 \mu \mathrm{g} / \mathrm{ml}$ respectively. The antibiotics were added asceptically, and in powder form, to cool autoclaved agar.

\section{$2.2 \mathrm{c}$ Culture and storage of yeast strains}

Strains of $\underline{\underline{S}}$. pombe were reisolated (most usually from long term silica gel storage) and several clones checked for ploidy and phenotype. 
Suitable clones were maintained on YEA slants at $4^{\circ} \mathrm{C}$ in screw capped bottles. Strains were reisolated periodically (every 4-6 weeks) from the YEA slants and checked as before. Clones were maintained on YEA or EMM agar (supplemented where necessary) and used for day to day use. Fresh YEA slants were prepared from silica gel stocks after several months. Many of the mutants isolated in this project were stored in skimmed milk/silica gel at $4^{\circ} \mathrm{C}$ using the procedure of Gutz et al. (1974).

2.2d Culture and storage of $\underline{E} \cdot \underline{c o l i}$

Stock strains of E. coli were stored at $-70^{\circ} \mathrm{C}$ in a $20: 80$

glycerol:LB broth mixture contained in screw capped vials. Bacterial stocks for routine work were maintained as single clones on solid LB agar (supplemented, where necessary, with ampicillin).

\subsection{Genetical analysis}

Techniques used in genetical analysis followed closely those described by Gutz et al. (1974).

\section{3a Yeast strains}

All mutant strains of $\underline{\mathrm{S}}$. pombe used were derived from the original isogenic wild type isolates $972 \underline{h}^{-}$and $975 \underline{h}^{+}$(Leupold, 1950). The majority of mutant strains used were obtained from the stock collection of Dr. P. A. Fantes (Zoology Department, Edinburgh University). The origin of strains obtained from elsewhere is indicated overleaf. 
Mutant

cyh1.C7

cyh2.A2

cyh4.U96

ben1.JY16

ben2.JY3O

ben $3 . J Y 25$

nda2.KM52

nda3.KM311

nda3.TB1005

$\overline{\mathrm{KM} 4}$

KM48

KM108

KM465

KM476

KM525

nda2.KM52

\section{Source}

Dr. A . Coddington

School of Biological

Sciences

University of East

Anglia, U.K.

Dr. M. Yamamoto

Laboratory of Molecular

Genetics

University of Tokyo

Japan.

Dr. M. Yanagida

Department of Biophysics

Faculty of Science

Kyoto University

Kyoto 606

Japan.

Dr. P. Nurse

ICRF Laboratories

London

UK.

\section{Reference}

(Ibrahim and Coddington, 1976)

(Yamamoto, 1980)
(Toda et al., 1983)

Umesono et al., 1983a)

(Toda et al., 1983) 
was carried out by exposing cells to U.V. illumination (Phillips P40/OG bulb - vertical distance $60 \mathrm{cms}$ from the surface of the agar) for 15 to 20 seconds; this dosage is sufficient to induce about $60 \%$ mortality of cells (P. A. Fantes, personal communication). Mutagenised plates were then incubated at the appropriate temperature to allow formation of colonies.

\section{3c Mating and sporulation}

In crosses involving the benomyl resistant cold sensitive mutants isolated in this project, the following modified procedure of Gutz et al. (1974) was adopted. Cells to be crossed were thinly spread on YEA agar and incubated overnight at either 30 or $35^{\circ} \mathrm{C}$. The following day equal quantities of the two cultures were mixed together, with a little water, on the surface of MEA agar. The plates were incubated for $2-3$ days at either 27 or $30^{\circ} \mathrm{C}$ to induce conjugation and sporulation. The presence of zygotic asci was determined by microscopical examination. In some crosses the presence of asci in mating cultures was determined by brief exposure to iodine vapour, as described by Gutz et al. (1974).

\section{3d Tetrad analysis}

Tetrad analysis was performed on YEA agar essentially as described by Gutz et al. (1974). Mature asci containing four spores were isolated (10-12 per plate) by micromanipulation using a fine glass needle linked to a Leitz micromanipulator. Ascospores were liberated from the isolated asci following prolonged incubation at either 27, 30 or $35^{\circ} \mathrm{C}$. The ascospores from each tetrad were separated in order across the plate by micromanipulation. The dissection plates were then incubated at a suitable temperature to allow outgrowth of ascospores. A master plate was prepared on YEA agar and used for phenotypic characterisation of progeny. The mating type of 
progeny was determined after matings with $\underline{h}^{-}$or $\underline{h}^{+}$tester strains, using the iodine staining reaction to identify sporulated cultures.

\section{3e Random spore analysis}

A loopful of mating culture containing asci was resuspended in $10 \mathrm{ml}$ of a 500-fold dilution (in $\mathrm{H}_{2} \mathrm{O}$ ) of stock helicase ('Suc d'helix pomatia'; Industria Biologique, France) and incubated overnight at either 30 or $35^{\circ} \mathrm{C}$. Helicase digests away wall material from the ascus and from vegetative cells. Ascospores are resistant to this treatment and a random population of 'free' spores is therefore generated. The ascospores were harvested after treatment, washed once in water, and the spore number/ml determined from haemocytometer counts. Spores were plated non-selectively onto YEA agar, at approximately 300 spores/plate, and were incubated at a suitable temperature to allow formation of colonies. These plates were generally used directly as masters for replication onto selective medium. In some cases, secondary master plates were prepared on YEA agar and used for the phenotypic characterisation of progeny.

\section{3f Dominance testing}

Diploids used in dominance testing were constructed using the properties of the mat2.102 marker essentially as described by Kohli et al. (1977). Zygotes of the form mat2.102/ $\underline{h}^{-}$fail to undergo meiosis, and stable prototrophic diploids may be selected on EMM agar when complementary markers are introduced via the parental strains. Confirmation of ploidy is made on the basis of cell size and staining intensity with magdala red (Kohli et al., 1977). A diploid of the form ade6.704 ben $4^{+} \underline{\mathrm{h}}^{-} /$mat2 2.102 ura 5.294 ben $^{+}{ }^{+}$was constructed and used as a wild type diploid in dominance tests. Ben4 mutations were crossed, as required, into the ade6.704h $\underline{\mathrm{h}}^{-}$and mat2.102 ura5.294 haploid parental strains. These strains were used in the 
construction of diploids heterozygous (e.g. ade 6.704 ben $4 . \mathrm{C} 10 \mathrm{~h}^{-} / \mathrm{mat}$ 2.102 ura5 5.294 ben $^{+}$), homozygous (e.g. ade6.704 ben $4.010 \underline{\mathrm{h}}^{-} /$mat 2.102 ura5.294 ben4.C10) or heteroallelic (e.g. ade6.704 ben4.D19(I) $\mathrm{h}^{-} /$mat 2.102 ura 5.294 ben4.D23(I)) for the ben 4 mutation. Four independent diploid clones from each construction were selected, and each clone was streaked out for single cells onto the test media and scored for benomyl sensitivity and cold sensitivity as described in Table 4.13 .

\section{3g Haploidization}

Haploidization experiments were carried out according to the method of Kohli et al. (1977) Stable diploid strains were constructed essentially as described above (2.3f). However, in these experiments it was necessary to introduce at least one auxotrophic marker per chromosome pair into the diploid strain. Diploids used for haploidization were of the following construction:

Chromosome I

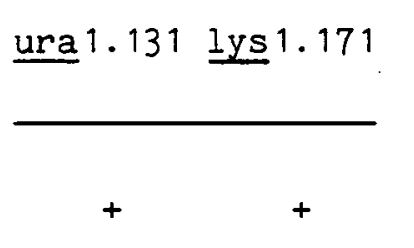

II

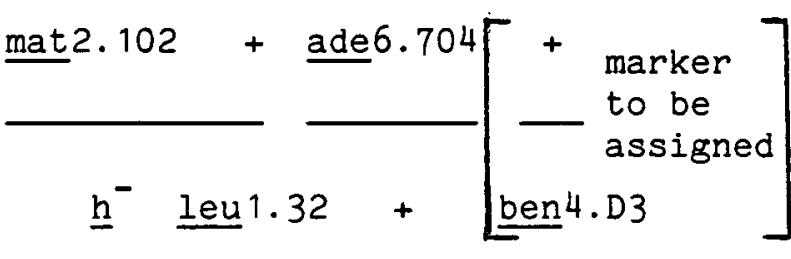

Three stable prototrophic diploid clones (each one from an independent mating) were isolated on EMM agar containing magdala red. Haploidization of diploids was induced by growing cells overnight on EMM agar containing $0.05 \% \mathrm{~m}$-fluorophenylalanine. After drug treatment the cells were plated onto fully supplemented EMM agar containing magdala red. Haploid clones (at least 100 colonies from each independent haploidịation experiment) were identified and picked onto fully supplemented agar. These master plates were replicated to the appropriate selective media and the phenotypes of the progeny scored. The segregation pattern of ben 4 with each of the auxotrophic markers 
was analysed using a $2 \times 2 x^{2}$ contingency test. A significant excess of parental phenotypes in any of the gene pair combinations tested was indicative of linkage. This criterion was used for subsequent chromosome allocation of the ben 4 locus.

\subsection{Physiological techniques}

\section{$2.4 a$ Temperature shift experiments}

Cells for temperature shift experiments were first checked for ploidy and phenotype. A loopful of cells was used to inoculate $5 \mathrm{ml}$ of EMM contained in a $25 \mathrm{ml}$ screw capped universal container. The culture was incubated at a suitable temperature until cells had reached stationary phase. Cultures grown up in this way at 25 or $30^{\circ} \mathrm{C}$ were retained for several days and used as stocks for physiological experiments. Cultures maintained at $35^{\circ} \mathrm{C}$ were discarded not longer than two days after cells had reached stationary phase. An aliquot of stationary phase cells was used to inoculate 100 or $200 \mathrm{ml}$ of EMM contained in Erlenmeyer flasks. The culture was incubated at the permissive temperature, with agitation, in a thermostatically controlled water bath. The temperature shift commenced when cells had reached an early exponential phase of growth $\left(A_{595}\right.$ 0.1-0.2). Approximately $60 \%$ of the culture volume was transferred to a fresh flask and then incubated in a separate water bath equilibrated to the desired temperature. The remainder of the culture was retained at the permissive temperature to serve as a control. When the ambient temperature rose above $20^{\circ} \mathrm{C}$, a cooling coil was placed in the water bath to obtain a restrictive temperature of $20^{\circ} \mathrm{C}$. Temperature shift experiments were repeated at least twice to ensure reproducibility. Transition points were estimated as described by Nurse et al. (1976). 


\section{$2.4 \mathrm{~b}$ Determination of cell number}

Cell number was determined from a $500 \mu l$ sample taken with a constriction pipette. Samples for counting were fixed in $2 \mathrm{ml}$ of a prefiltered ice cold $0.1 \%$ formaldehyde $/ 0.1 \% \mathrm{NaCl}$ solution. Cells were counted electronically in a Coulter (model B) particle counter as described by Mitchison (1970).

\section{4c Determination of cell length}

Cell length determinations were made from Giemsa stained preparations. Cell length was measured using a graticule eyepiece in combination with the $63 \mathrm{x}$ planapochromatic oil immersion objective on a Zeiss photomicroscope. The graticule was first calibrated against a slide micrometer for use with this objective. At least 30-50 cells per sample were measured using the criterion of Mitchison (1970).

\section{$2.4 d$ Culture turbidity}

Culture turbidity, related to culture dry mass (Mitchison, 1970), was measured in a Pye Unicam SP 600 spectrophotometer from the $A_{595 \mathrm{~nm}}$ of a $3 \mathrm{ml}$ culture sample held in a quartz cuvette ( $1 \mathrm{~cm}$ path length). Distilled water was used in the reference cuvette.

\section{4 e Septated cells}

The percentage of septated cells was determined as described by Mitchison (1970). Dark field optics were used and at least 300 cells per sample were scored.

\section{$2.4 \mathrm{f}$ Binucleated cells}

The percentage of binucleated cells was determined from Giemsa stained preparations. Cells were examined using the $63 \mathrm{x}$ planapochromatic oil immersion objective on a Zeiss photomicroscope with bright field illumination. Single, non-septated cells containing two clearly defined nuclei were scored as binucleated. At least 300 cells per sample were examined. 


\section{$2.4 \mathrm{~g} \quad$ Drug sensitivity testing}

A replica plating technique was used to perform all drug sensitivity tests. Cells to be tested were picked onto YEA or EMM agar (supplemented where necessary) and incubated overnight at $35^{\circ} \mathrm{C}$. A wild type strain was included in each test. These master plates were used for replicating the cells onto drug containing media. Replicates were scored for growth after 2-3 days incubation at $35^{\circ} \mathrm{C}$. Growth was scored relative to the wild type growing under the same conditions, but in the absence of the drug. Drugs were obtained from the sources listed in Tables 2.1 and 2.2 , and were stored as concentrated stock solutions in either ethanol or water. Aliquots of the stock solutions were added to the media either before or after autoclaving. Aliquots of the stock solutions of the antimicrotubule agents used (Table 2.1) were added to the media prior to autoclaving. The remaining drugs used (Table 2.2) were added to autoclaved media when cool.

Growth of the wild type and other strains tested was also monitored on a control plate containing an amount of ethanol equivalent to that used in the preparation of the highest drug concentration tested. Cells were exposed to a maximum concentration of ethanol of $2 \%$ in these tests. The growth of neither the wild type nor of the other strains tested was significantly inhibited at this level. 
Table 2.1 Details of antimicrotubule agents ${ }^{1}$ used in drug sensitivity tests.

Name

Benomy ${ }^{2}$

(recrystallised)

$\mathrm{MBC}^{2}$

( $98 \%$ purity)

$\mathrm{TBZ}^{2}$

( $90 \%$ purity)

$\mathrm{APM}^{2}$

Fenbendazole

CIPC $^{2}$

m-fluorophenylalanine

p-fluorophenylalanine

Nocodazole ${ }^{2}$

Griseofulvin

\section{Source}

Dr. R. J. Howard

E.I. Du Pont de Nemours

Experimental station

Wilmington Delaware 19898

II

II

Dr. P. A. Round

MSD/AGVET

Hertford Road

Hoddesdon

Herts., England

Bayer AG

KOIn 5-500, FDR

Drs. Schorr \& Bartmann

Hoechst

6230 Frankfurt (M) 80

FDR

Sigma

Sigma

Sigma

Sigma

Sigma
$\mathrm{H}_{2} \mathrm{O}$

$\mathrm{H}_{2} \mathrm{O}$

$\mathrm{H}_{2} \mathrm{O}$

ethanol

Solvent used in preparation of stock solution ( $5 \mathrm{mg} / \mathrm{ml}$ )

ethanol

ethanol

ethanol

$\mathrm{H}_{2} \mathrm{O}$

ethanol

ethanol

\section{Notes}

1. A description of the mode of action of each of these compounds is presented in Table 5.2 .

2. The nomenclature of these compounds is given in Figure 2.1. The chemical structure of benomyl, MBC, TBZ, nocodazole and fenbendazole is also given in this Figure. 
<smiles>CCCCNC(=O)n1c(NC(=O)OC)nc2ccccc21</smiles>

benomyl<smiles>c1ccc2[nH]c(-c3cscn3)nc2c1</smiles>

thiabendazole<smiles>[R]=Cc1ccc2nc(NC(=O)OC)[nH]c2c1</smiles><smiles>O=CC(=O)c1cccs1</smiles>

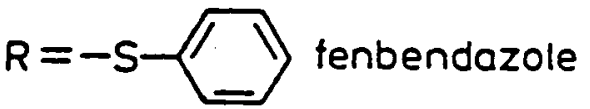

Figure 2.1 Nomenclature and structural formula of some antimicrotubule agents used in drug sensitivity tests (see also Table 2.1).

Benomyl - (methyl-1-(butylcarbamoyl)-benzimidazol-2-ylcarbamate). $M B C$ - methyl benzimidazol-2-yl-carbamate.

TBZ - 2-(thiazol-4-yl) benzimidazole.

Nocodazole - methyl (5-(2-thienylcarbonyl)-1H-benzimidazol-2-yl)carbamate.

CIPC - 1s.opropylN-(3-chlorophenyl)-carbamate.

APM - O-methyl-O(4-methyl-6-nitrophenyl)-N-isopropylphosphoroiomidate. 
Table 2.2 Details of other inhibitors used in drug sensitivity tests.

Name ${ }^{1}$

Cycloheximide

8-hydroxyquinoline

Hydroxyurea

Iodoacetate
Source

Sigma

Sigma

Sigma

$\mathrm{BDH}$
Solvent used in preparation of stock solution

( $5 \mathrm{mg} / \mathrm{ml}$ )

$70 \%$ ethanol

$70 \%$ ethanol

$\mathrm{H}_{2} \mathrm{O}$

$\mathrm{H}_{2} \mathrm{O}$

\section{Note}

1. A brief description outlining the mode of action of each drug is included in the text (Section 5.3b). Each of these compounds was added to the media after autoclaving. 


\subsection{Microscopy \\ 2.5a Giemsa staining}

Giemsa staining followed the procedure of Nurse et al. (1976). Cells from a $1 \mathrm{ml}$ culture sample were filtered as described by Mitchison (1970), smeared onto a slide and then heat fixed at $80^{\circ} \mathrm{C}$ for 10 minutes. The fixed cells were water rinsed and then post fixed for 15 minutes in freshly prepared Carnoy's solution.

Carnoy's solution:

$\begin{array}{lr}\text { Ethanol } & 180 \mathrm{ml} \\ \text { Chloroform } & 90 \mathrm{ml} \\ \text { Glacial acetic acid } & 30 \mathrm{ml} .\end{array}$

The fixative was removed by water washing for 10 minutes. RNA was extracted from cells by hydrolysis in $1 \mathrm{~N} \mathrm{HCL}$ at $60^{\circ} \mathrm{C}$ for 30 minutes. Excess acid was removed with a 10 minute water wash. Staining of cells was carried out in $0.1 \mathrm{M}$ phosphate buffer $\mathrm{pH} 6.8$, containing $4 \%$ freshly added Giemsa stain (Lamb). Staining times were generally between 30 and 60 minutes. The progress of staining was monitored using low power $(20 \mathrm{x})$ bright field microscopy. When fully dry, cells were examined using the $63 \mathrm{x}$ planapochromatic oil immersion objective on a Zeiss photomicroscope.

\section{5b Acid fuschin staining}

The method of McCully and Robinow (1971) was used. Cells were recovered from a $3 \mathrm{ml}$ culture sample by filtration and smeared onto a microscope slide. The cells were briefly air dried then plunged immediately into Helly's fixative (see below) containing $0.6 \%$ ( $/ v$ ) of freshly added formaldehyde (37\%).

Helly's fixative, per $100 \mathrm{ml} \mathrm{H}_{2} \mathrm{O}$ :

$$
\begin{array}{ll}
\text { Mercuric chloride } & 5.0 \mathrm{~g} \\
\text { Potassium dichromate } & 3.0 \mathrm{~g}
\end{array}
$$

Fixation was for 5 minutes, after which the cells were water washed. Cells were stained for 5-10 minutes in a $25 \mu \mathrm{g} / \mathrm{ml}$ aqueous 
solution of acid fuschin (Geo. Gurr Ltd.). Vaseline ringed wet mounts were prepared and cells examined using the optical system described above (2.5a). Photomicrographs of Giemsa or acid fuschin stainẹd cells were taken by automatic exposure onto Pan F film (ASA 50) with a Zeiss photomicroscope.

\section{5c Immunofluorescent staining}

A modified version of the procedure described by Kilmartin and Adams (1984) was used in attempts to detect microtubules in $\underline{\text { S. }}$ cerevisiae and $\underline{\mathrm{S}}$. pombe.

\section{Fixation of cells}

Cells were harvested from a $100 \mathrm{ml}$ culture sample $\left(10^{6}-10^{7}\right.$ cells $/$ ml) by centrifugation and washed once in water. The cells were fixed for 2 hours at room temperature in $5 \mathrm{ml}$ of phosphate buffer (40mM K $\mathrm{KPO}_{4}, 40 \mathrm{mM} \mathrm{KH} \mathrm{PO}_{4}, 0.5 \mathrm{mM} \mathrm{MgCl} 2, \mathrm{pH} 6.5$ [buffer A]) containing $0.6 \mathrm{ml}$ of $37 \%$ formaldehyde (freshly added). Fixed cells were washed three times in $5 \mathrm{ml}$ sorbitol/phosphate buffer $(1.2 \mathrm{M}$ sorbitol in buffer A). The cell walls of $\underline{S}$. cerevisiae were removed by incubation in $2 \mathrm{ml}$ of sorbitol/phosphate buffer containing $55 \mu \mathrm{l}$ of glusulase (Sigma) for 2 hours at $35^{\circ} \mathrm{C}$. The sample was washed once in $10 \mathrm{ml}$ of sorbitol/phosphate buffer and resuspended in $10 \mathrm{ml}$ of the same buffer. For the removal of the $\underline{S}$. pombe cell wall the enzyme preparation Novozyme 234 (Novo) was substituted for glusulase. In this case, the original fixative was removed from cells by two washes in $5 \mathrm{ml}$ of $0.6 \mathrm{MKCl}, 0.01 \mathrm{M}$ phosphate/citrate, $5 \mathrm{mM}$ dithiothreitol, $\mathrm{pH} 6.0$ (buffer B). The cells were resuspended in $5 \mathrm{ml}$ of buffer $\mathrm{B}$ containing $30 \mathrm{mg} / \mathrm{ml}$ of Novozyme 234. Digestion was carried out for 20-30 minutes at $30^{\circ} \mathrm{C}$. The extent of wall digestion was monitored by bright field microscopy. Cells were washed once in buffer $B$ and then twice in $5 \mathrm{ml}$ of sorbitol/phosphate before continuing with the protocol as 
below. In some experiments (see text) the cell wall of yeast was removed prior to fixation.

\section{Preparation of slides}

$5 \mathrm{Hl}$ of a $0.1 \%$ aqueous solution of polylysine $(400,000$ - M Sigma) was added, as required, to the wells of an eight well multitest slide (Miles Labs.). After 30 seconds, excess fluid was removed by aspiration, and the wells washed three times in a drop of water. A $10 \mu l$ aliquot of the cell suspension (see above) was then placed in a coated well. Cells were found to adhere strongly to the polylysine layer; excess fluid being removed by aspiration. When dry, the slide was immersed in methanol $\left(-20^{\circ} \mathrm{C}\right)$ for 6 minutes followed by immersion in acetone $\left(-20^{\circ} \mathrm{C}\right)$ for 30 seconds. The slide was dried in air before continuation of the staining protocol.

\section{Staining of cells}

A $5 \mu l$ aliquot of $0.05 \mathrm{M} \mathrm{KH}_{2} \mathrm{PO}_{4}, 0.15 \mathrm{M} \mathrm{NaCl}, 0.1 \% \mathrm{NaN}_{3}, 1.0 \% \mathrm{BSA}$, pH 7.4 (buffer C) containing $4.16 \mu g$ of the first antibody (antiyeast tublin monoclonal antibody YOL 1/34 (Kilmartin et al., 1982); a kind gift from Dr. J. V. Kilmartin, MRC molecular biology unit, Cambridge University) was added to each well containing prepared cells. The slide was incubated in a moist environment (an enclosed petri dish containing wet tissues) for 1.5 hours. The primary antiserum was removed by aspiration and the well washed at least 5 times with buffer $C$. The second antibody used was FITC conjugated antirat IgG antibody (Miles Labs.). $5 \mathrm{\mu l}$ of a 1:16 (antibody: $\mathrm{H}_{2} 0$ ) dilution of the stock second antibody was added to each well and the slide placed in a moist environment at room temperature for 2 hours. The second antibody was then removed and the well washed 5 times with buffer C. A drop of $90 \%$ glycerol was placed in the well and permanent 'cutex' ringed mounts prepared. Stained cells 
were examined using either the $40 \mathrm{x}$ (Neofluar) or the 100x (Planochromatic) objective on a Zeiss photomicroscope. Epifluorescent illumination (Wotan Mercury Lamp HBO-50W) was used in combination with Zeiss filter set 487709 for FITC excitation. Photomicrographs were taken by manual exposure onto Kodak Tri-X (ASA 400) film. Stained preparations were stored in the dark at $-20^{\circ} \mathrm{C}$.

\section{5d DAPI and ethidium bromide staining}

Cells were stained, either singly or in combination, with 4 , 6-Diamidine-2-phenylindoledihydrochloride (DAPI) and ethidium bromide (3.8-diamino-6-ethyl-5-phenylphenanthridium bromide) as described by Toda et al. (1981).

\section{DAPI staining}

Cells from a 1-5 ml culture sample were pelleted in a microcentrifuge. The cells were washed twice in ice cold water and then resuspended in $100 \mu l$ of the same. A $5 \mu 1$ aliquot of a stock DAPI (Sigma) solution $\left(100 \mu g / m I\right.$ in $\left.\mathrm{H}_{2} \mathrm{O}\right)$ was added to the cell suspension and mixed in by inversion. Staining was carried out, on ice, for 510 minutes. A drop of the stained culture was transferred to a polylysine coated slide (see Section $2.5 \mathrm{c}$ and below) and semipermanent vaseline or 'cutex' ringed wet mounts were prepared. Epifluorescent illumination (see above) was used in combination with filter set 487702 for DAPI excitation. Stained cells were examined using either a 40x (Neofluar) or a 100x (Planochromatic) objective on a Zeiss photomicroscope.

\section{Ethidium bromide staining}

Cells were harvested and washed as for DAPI staining. A $5 \mu l$ aliquot from a stock ethidium bromide (Sigma) solution ( $200 \mu \mathrm{g} / \mathrm{ml}$ in $\mathrm{H}_{2} \mathrm{O}$ ) was added to the $100 \mathrm{\mu l}$ cell suspension and staining carried out at room temperature for 30 minutes. Stained cells were examined 
using either the 40x (Neofluar) or the 100x (Planochromatic) objective on a Zeiss photomicroscope. Epifluorescent illumination was used in combination with Zeiss filter set 487715 for excitation of ethidium bromide.

For DAPI/ethidium bromide double staining, the cells were first stained with DAPI as described above. Ethidium bromide was then added and staining carried out for a further 30 minutes at room temperature. Cells were examined as above using the appropriate filter combination.

Photomicrographs of DAPI and ethidium bromide stained cells were taken by manual exposure (10-30 seconds) onto Kodak Tri-X (ASA 400) film. It was found helpful to immobilise cells on the slide to obtain good photographic results. This was achieved by coating slides in a $0.1 \%$ polylysine solution, as described by Mazia et al. (1975).

\section{5e Electron microscopy}

The method of Byers and Goetsch (1975), as modified by King and Hyams (1982), was followed. Cells were harvested from a $100 \mathrm{ml}$ culture sample and resuspended in $5 \mathrm{ml}$ of $0.1 \mathrm{M}$ sodium cacodylate, $5 \mathrm{mM} \mathrm{CaCl} 2$, pH 6.8 (buffer D) containing $2.5 \%(\mathrm{v} / \mathrm{v})$ glutaraldhyde (EM grade) and incubated for 30 minutes at room temperature. The cells were pelleted and resuspended in fresh fixative in buffer D for 16 hours at $4^{\circ} \mathrm{C}$. The fixative was removed by washing cells twice in $10 \mathrm{ml}$ of buffer D. This was followed by two further washes in $10 \mathrm{ml}$ of $0.6 \mathrm{M} \mathrm{KCL}, 0.1 \mathrm{M}$ phosphate/citrate, $\mathrm{pH} 5.8$ (buffer $\mathrm{E}$ ). Cell walls were removed enzymatically in $5 \mathrm{ml}$ of buffer $\mathrm{E}$ containing $5 \mathrm{mM}$ dithiothreitol and $30 \mathrm{mg} / \mathrm{ml}$ Novozyme 234 (Novo). Wall digestion was carried out at $35^{\circ} \mathrm{C}$ for at least 30 minutes. The extent of wall removal was monitored by bright field microscopy. The reaction 
was terminated by washing cells twice in buffer $E$ containing $2.0 \%$ osmium tetroxide (EM grade). The cells were stained by making the sample $2.0 \%(\mathrm{v} / \mathrm{v})$ with a saturated solution of uranyl acetate. Staining was for 60 minutes at room temperature. The sample was then pelleted by centrifugation and dehydrated in a graded series of acetones as follows:

$\begin{array}{llcl}30 \% & \text { acetone } & 30 \text { minutes } & \text { room temperature } \\ 60 \% & \text { acetone } & " & " \\ 80 \% & \text { acetone } & n & " \\ 100 \% \text { dry acetone } & " & " \\ 100 \% \text { dry acetone } & \text { overnight }\end{array}$

The dehydrated sample, by now a solid pellet, was impregnated with Spurr resin (Spurr, 1969) in the following steps at room temperature:
3:1 acetone (100\%) : Spurr resin / 7 hours
$1: 3$ acetone $(100 \%)$ : Spurr resin / overnight
Spurr resin
$/ 7$ hours

Spurr resin was purchased in kit form (EM Scope) and prepared according to the manufacturer's instructions. The sample was transferred to a mould (Kartell type Eppendorf tube) and 2-3 $\mathrm{ml}$ of fresh Spurr resin was added. Resin was polymerised by baking at $60^{\circ} \mathrm{C}$ for 16 hours.

\section{Preparation and examination of sections}

Ultrathin sections were cut using a diamond or glass knife on an ultramicrotome (LKB Ultrotome model 4801A). Gold or silver sections were picked onto formvar coated copper grids and then post stained with lead citrate according to the method of Reynolds (1963). Sections were examined and photographed in a Joel 200 TEM operating at either 80 or $100 \mathrm{kV}$. The magnification of the microscope was previously calibrated against a diffraction grating. 


\subsection{Molecular genetic techniques}

All chemicals used in experimental work were analytical grade unless otherwise stated.

\section{6a Bacterial transformations}

Strain JA221 of E. coli was transformed with plasmid DNA according to the method of Dagert and Ehrlich (1979). Cells were grown in $50 \mathrm{ml}$ of $L B$ medium at $37^{\circ} \mathrm{C}$ to an $\mathrm{A}_{650}$ value of 0.2 . The culture was chilled on ice and the cells harvested by centrifugation at $4^{\circ} \mathrm{C}$. The cell pellet was resuspended in $20 \mathrm{ml}$ of ice cold $0.1 \mathrm{M}$ $\mathrm{CaCl}_{2}$ and held on ice for 20 minutes. The cells, now considered competent for transformation, were harvested and resuspended in $0.5 \mathrm{ml}$ of cold $0.1 \mathrm{M} \mathrm{CaCl}_{2}$. To $100 \mathrm{\mu l}$ aliquots of the cell suspension was added $10 \mathrm{Hl}$ of TE (10mM Tris.HCl, 1mM EDTA pH 7.6) buffer containing between 0.1 and $0.5 \mu g$ of plasmid DNA. The sample was mixed and placed on ice for 20 minutes, after which the cells were heat shocked for 5 minutes at $37^{\circ} \mathrm{C}$. Fresh $\mathrm{LB}$ medium $(2 \mathrm{ml}$ ) was added to each sample and incubation, with shaking, was carried out at $37^{\circ} \mathrm{C}$ for 60 minutes. The cells were harvested and then resuspended in $0.5 \mathrm{ml}$ of LB medium. To select for transformants, cells were spread onto LB agar containing $100 \mu \mathrm{g} / \mathrm{ml}$ ampicillin and incubated overnight at $37^{\circ} \mathrm{C}$.

\section{$2.6 \mathrm{~b}$ Yeast transformation}

The method of Beach and Nurse (1981), with slight modifications, was used. Cells of ben4.D3 ura 4.294 or ben $4^{+}$ura 4.294 were grown at $35^{\circ} \mathrm{C}$ in $100 \mathrm{ml}$ of $\mathrm{YE}$ supplemented with $75 \mu \mathrm{g} / \mathrm{ml}$ of uracil to an $A_{595 n m}$ of $0.3-0.5$. The cells were harvested by centrifugation and protoplasts prepared, as described in the above reference, using Novozyme 234 (Novo). Protoplasts were washed three times in $5 \mathrm{ml}$ of $10 \mathrm{mM}$ Tris.HCl pH 7.6, 1.2M sorbitol (Tris/sorbitol). Washed protoplasts $\left(10^{7}-10^{8}\right)$ were resuspended in $0.1 \mathrm{ml}$ of Tris/sorbitol buffer 
made $10 \mathrm{mM}$ with $\mathrm{CaCl}_{2}$, to which was added 10-20 $\mathrm{\mu l}$ of Tris/sorbitol containing plasmid DNA. The sample was incubated at $25^{\circ} \mathrm{C}$ for 15 minutes. After this, $1 \mathrm{ml}$ of Tris/sorbitol buffer, made $10 \mathrm{mM}$ with $\mathrm{CaCl}_{2}$ and containing 20\% (w/v) polyethylene glycol 4000 (BDH), was added to the sample. Following 15 minutes incubation at $25^{\circ} \mathrm{C}$, the protoplasts were pelleted and resuspended in $0.5 \mathrm{ml}$ of Tris/sorbitol containing $10 \mathrm{mM} \mathrm{CaCl}{ }_{2}, 10 \mu \mathrm{g} / \mathrm{ml}$ uracil and $0.5 \mathrm{mg} / \mathrm{ml}$ yeast extract. The sample was incubated at $35^{\circ} \mathrm{C}$ for 30 minutes. The protoplasts were then pelleted and plated out onto regeneration agar. (EMM agar containing $0.6 \mathrm{M} \mathrm{KCL}$ and $1.2 \mathrm{M}$ sorbitol) in $0.2 \mathrm{ml}$ aliquots of Tris/ sorbitol buffer. Plates were incubated for up to seven days at $35^{\circ} \mathrm{C}$ to select for transformant colonies. Samples of protoplasts were also plated, non-selectively, onto regeneration control agar (EMM regeneration agar containing $75 \mu g / m \mathrm{l}$ uracil) and incubated under the same conditions.

\section{$2.6 \mathrm{c}$ Small scale purification of plasmids}

Isolation of plasmid DNA from transformed JA221 cells was performed using a modified version of the alkaline SDS lysis procedure of Birnboim and Doly (1969). Cells were grown overnight at $37^{\circ} \mathrm{C}$ in $5 \mathrm{ml}$ of $\mathrm{LB}$ medium containing $100 \mu \mathrm{g} / \mathrm{ml}$ ampicillin. The cells were pelleted and resuspended in $100 \mu \mathrm{l}$ of $50 \mathrm{mM}$ glucose, 10mM EDTA, 25mM Tris.base, $\mathrm{pH} 8.0$ (buffer F) containing $2 \mathrm{mg} / \mathrm{ml}$ of freshly added lysozyme, and the sample incubated at room temperature for 5 minutes. Cells were lysed by the addition of $200 \mu \mathrm{l}$ of a freshly prepared $0.2 \mathrm{M}$ $\mathrm{NaOH} / 1 \%$ SDS solution. The sample was mixed gently and then placed on ice for 5 minutes. $150 \mu$ of $3 M$ sodium acetate ( $\mathrm{pH} 4.8$ ) was then added, and the sample mixed by inversion. After 10 minutes on ice, the sample was spun in a microcentrifuge for 10 minutes at $4^{\circ} \mathrm{C}$ to pellet the denatured protein/chromosomal DNA complex. The supernatant 
(containing plasmid DNA) was removed and extracted once against an equal volume of TE saturated phenol. The aqueous supernatant was removed and extracted twice against an equal volume of $24: 1$ chloroform: isoamyl alcohol. Plasmid DNA was precipitated from the aqueous supernatant by the addition of two volumes of absolute ethanol. After 5 minutes incubation at room temperature plasmid DNA was recovered by centrifugation for 5 minutes at $4^{\circ} \mathrm{C}$ in a microcentrifuge. The ethanol was discarded and the sample dried under vacuum. The sample was finally resuspended in a suitable volume of $\mathrm{H}_{2} \mathrm{O}$ or $\mathrm{TE}$ buffer.

\section{6d Large scale isolation of plasmids}

Larger amounts of plasmid DNA (100-200 $\mu \mathrm{g})$ were prepared using a scaled up version of the above technique. Transformed cells were grown overnight, with shaking, at $37^{\circ} \mathrm{C}$ in two $500 \mathrm{ml}$ batches of LB medium containing ampicillin. Cells were harvested (7,000 r.p.m. Sorvall GSA rotor, 10 minutes at $4^{\circ} \mathrm{C}$ ) and resuspended in $40 \mathrm{ml}$ of buffer $\mathrm{F}$ (see above) containing $160 \mathrm{mg}$ of freshly added lysozyme. After 10 minutes incubation at room temperature $80 \mathrm{ml}$ of a freshly prepared $0.2 \mathrm{M} \mathrm{NaOH} / 1 \%$ SDS solution was added and the sample mixed by gentle inversion. The sample was chilled on ice for 10 minutes followed by the addition of $40 \mathrm{ml}$ of cold $5 \mathrm{M}$ potassium acetate, $\mathrm{pH}$ 4.8. The sample was mixed and allowed to stand on ice for at least 60 minutes. The denatured protein/chromosomal DNA complex was removed by centrifugation $(11,000$ r.p.m. Sorvall GSA rotor, 15 minutes at $\left.4^{\circ} \mathrm{C}\right)$. The clear supernate was transferred to a clean centrifuge bottle and the nucleic acid was precipitated by the addition of $0.6 \mathrm{x}$ supernate volume of $\operatorname{cold}\left(-20^{\circ} \mathrm{C}\right)$ isopropanol. The precipitate was pelleted $(11,000$ r.p.m. Sorvall GSA rotor for 15 minutes at $4^{\circ} \mathrm{C}$ ) and taken up in $11 \mathrm{ml}$ of $\mathrm{TE}$ buffer. The sample was 
neutralised ( $\mathrm{pH} 7.0-8.0$ ) by the addition of $2 \mathrm{M}$ Tris.base and made $50 \mathrm{mM}$ with EDTA.

\section{6e Purification of plasmid DNA in caesium chloride/ethidium bromide}

gradients

Plasmid DNA was purified by dye-buoyant centrifugation in caesium chloride gradients. To $13.4 \mathrm{ml}$ of the sample was added $14.8 \mathrm{gm}$ of $\mathrm{CsCl}$. After dissolution of the $\mathrm{CsCl}, 1.4 \mathrm{ml}$ of a $10 \mathrm{mg} / \mathrm{ml}$ ethidium bromide solution was added and the sample divided between two $10 \mathrm{ml}$ polyallomer centrifuge tubes (MSE). The tubes were capped and paraffin added as an overlay to exclude air spaces. The samples were centrifuged in a $10 \times 10 \mathrm{ml} \mathrm{Ti}$ rotor (MSE) at $35,000 \mathrm{r} . \mathrm{p} . \mathrm{m}$. for 60 hours at $18^{\circ} \mathrm{C}$. The plasmid band was visualised by U.V. illumination and removed by syringe. Ethidium bromide was removed from the sample by repeated extractions in TE saturated butanol. DNA was precipitated at $4^{\circ} \mathrm{C}$ for 16 hours by the addition of 3 volumes $70 \%$ ethanol. The DNA was recovered by centrifugation $(5,000 \mathrm{r} . \mathrm{p} . \mathrm{m}$. Sorvall HB-4 rotor, 10 minutes at $4^{\circ} \mathrm{C}$ ) and dried under vacuum. The sample was resuspended in $1 \mathrm{ml}$ of $\mathrm{TE}$ buffer (made $0.15 \mathrm{M}$ with $\mathrm{NaCl}$ ) and the DNA precipitated with two volumes of ethanol.at $-20^{\circ} \mathrm{C}$ for four hours. The ethanol precipitation step was repeated and the DNA finally taken up in a suitable volume of TE buffer.

\section{6f Quantitation of DNA}

A 10-50 $\mu 1$ sample of purified plasmid DNA was added to $1 \mathrm{ml}$ of TE buffer and the $A_{260}$ measured in a Pye Unicam (SP 800) U.V. spectrophotometer. TE buffer was used in the reference cuvette. A conversion factor of $50 \mu g / m l$ per $A_{260}$ unit was used.

\section{$2.6 \mathrm{~g}$ Storage of DNA}

For short term storage, plasmid DNA was maintained as a $200 \mu \mathrm{g} / \mathrm{ml}$ stock in TE buffer at $4^{\circ} \mathrm{C}$. A drop of chloroform was added to the tube 
to prevent microbial contamination. For long term storage plasmid

DNA was kept as an ethanol precipitate at $-20^{\circ} \mathrm{C}$.

2.6h Restriction digests of DNA

Commercially available (BRL) restriction endonucleases were used. The reaction conditions used were those suggested by the manufacturer for each specific enzyme. Digestion reactions were terminated by the addition of $0.2 x$ reaction volume of $0.2 \mathrm{M}$ EDTA $\mathrm{pH} 8.0$, followed by heat inactivation at $65^{\circ} \mathrm{C}$ for 10 minutes.

$2.6 i$ Ligation of DNA

Attempted cohesive end ligation of DNA was carried out essentially as described by Maniatis et al. (1982). Approximately 0.1-0.3 $\mu g$ of each species of DNA to be ligated was recovered by ethanol precipitation, dried and pooled by resuspension in $7 \mu \mathrm{l}$ of $\mathrm{H}_{2} \mathrm{O}$. To the sample was added $1 \mu \mathrm{I}$ of $10 \mathrm{x}$ ligation reaction buffer (10x: $0.6 \mathrm{M}$ Tris. $\mathrm{HCl}, 50 \mathrm{mM} \mathrm{MgCl}_{2}$, 50mM dithiothreitol, $\mathrm{pH} 7.5$ ), as well as $1 \mu \mathrm{l}$ of a stock ATP solution (10mM). Approximately 1 unit of T4 DNA ligase (BRL) was added and the reaction allowed to proceed at $12^{\circ} \mathrm{C}$ for at least 16 hours. The reaction was terminated by the addition of $0.2 \mathrm{x}$ volume $0.2 \mathrm{M}$ EDTA $(\mathrm{pH} 8.0)$. Aliquots of the reaction mixture were used directly in bacterial transformations (Section 2.6a).

\section{$2.6 \mathrm{j}$ Agarose gel electrophoresis}

Agarose gel electrophoresis was performed essentially as described by Maniatis et al. (1982). The electrophoresis buffer used was $30 \mathrm{mM} \mathrm{NaH}{ }_{2} \mathrm{PO}_{4} \cdot 2 \mathrm{H}_{2} \mathrm{O}, 1 \mathrm{mM}$ EDTA, 36mM Tris.HCl, pH 7.7. Electrophoresis was through $0.7 \%$ agarose (Type. II, low E.E.O. [Sigma]) gels cast between the plates of a vertical electrophoresis apparatus (dimensions either $11 \mathrm{~cm} \times 14 \mathrm{~cm}$ or $11 \mathrm{~cm} \times 22 \mathrm{~cm})$. Sample DNA was generally taken up in $20 \mu 1$ of TE buffer. Prior to loading, $0.2 x$ sample volume of loading/marker buffer ( $40 \%(\mathrm{v} / \mathrm{v})$ glycerol in $\mathrm{H}_{2} \mathrm{O}$ containing $0.25 \%$ 
bromophenol blue) was added to each sample. Electrophoresis was usually carried out for $2-4$ hours $(60 \mathrm{~V} / 60 \mathrm{~mA})$. Following electrophoresis, the gel was stained in a $0.5 \mu \mathrm{g} / \mathrm{ml}$ aqueous solution of ethidium bromide. The pattern of DNA fragments was visualised by U.V. illumination (transilluminator - Ultra Violet Products Ltd.) and photographs taken using a Polaroid MP4 camera onto Polaroid Type 667 film.

\section{$2.6 \mathrm{k}$ Recovery of DNA fragments from agarose gels}

Recovery using low melting point agarose

The procedure of Maniatis et al. (1982) was followed with slight modifications. Fragments of DNA were separated by electrophoresis through $0.7 \%$ low melting point agarose (BRL) gels as described in Section 2.6j. Electrophoresis was carried out at $4^{\circ} \mathrm{C}$. DNA fragments were identified by ethidium bromide staining and visualised with U.V. illumination. The required band was excised from the gel in a minimum volume of agarose, to which was added 2 volumes of TE buffer. The agarose was disrupted by vortex mixing and then melted at $65^{\circ} \mathrm{C}$ for 20 minutes. The sample was then extracted three times against an equal volume of $T E$ saturated phenol at $65^{\circ} \mathrm{C}$. The aqueous phase was removed carefully, so as to avoid contaminating agarose at the interface, and transferred to a clean Eppendorf tube. The sample was then extracted twice against equal volumes of chloroform. The aqueous phase was removed and made $0.15 \mathrm{M}$ with $\mathrm{NaCl}$. The $\mathrm{DNA}$ was recovered by ethanol precipitation at $-20^{\circ} \mathrm{C}$.

Recovery using the freeze-squeeze technique

The recovery procedure of Thuring et al. (1978) was used. The desired fragment was identified and excised from the gel as described above. The agarose block was placed in an envelope of parafilm and solidified at $-20^{\circ} \mathrm{C}$. Fluid was exuded from the frozen 
block by gentle pressure between thumb and forefinger (fingers gloved, and previously cooled on ice). The few drops of exudate were collected in an Eppendorf tube, and then spun in a microcentrifuge for two minutes to remove any contaminating agarose fragments. The supernatant was removed and made $0.15 \mathrm{M}$ with $\mathrm{NaCl}$. The DNA was recovered by precipitation in two volumes of ethanol at $-20^{\circ} \mathrm{C}$ for two hours.

\section{Recovery by electroelution}

A modification (D. M. McSorley, personal communication) of the general procedure described by Smith (1980) was used. A schematic diagram of the electrophoresis apparatus used for the electroelution of DNA is given below. The agarose block containing the DNA to be recovered was placed on top of the grid (1), so as to be positioned above the reservoir (2). The apparatus was then filled with electrophoresis buffer, making sure to exclude air bubbles from the system especially from around the grid (1). Electrophoresis was carried out

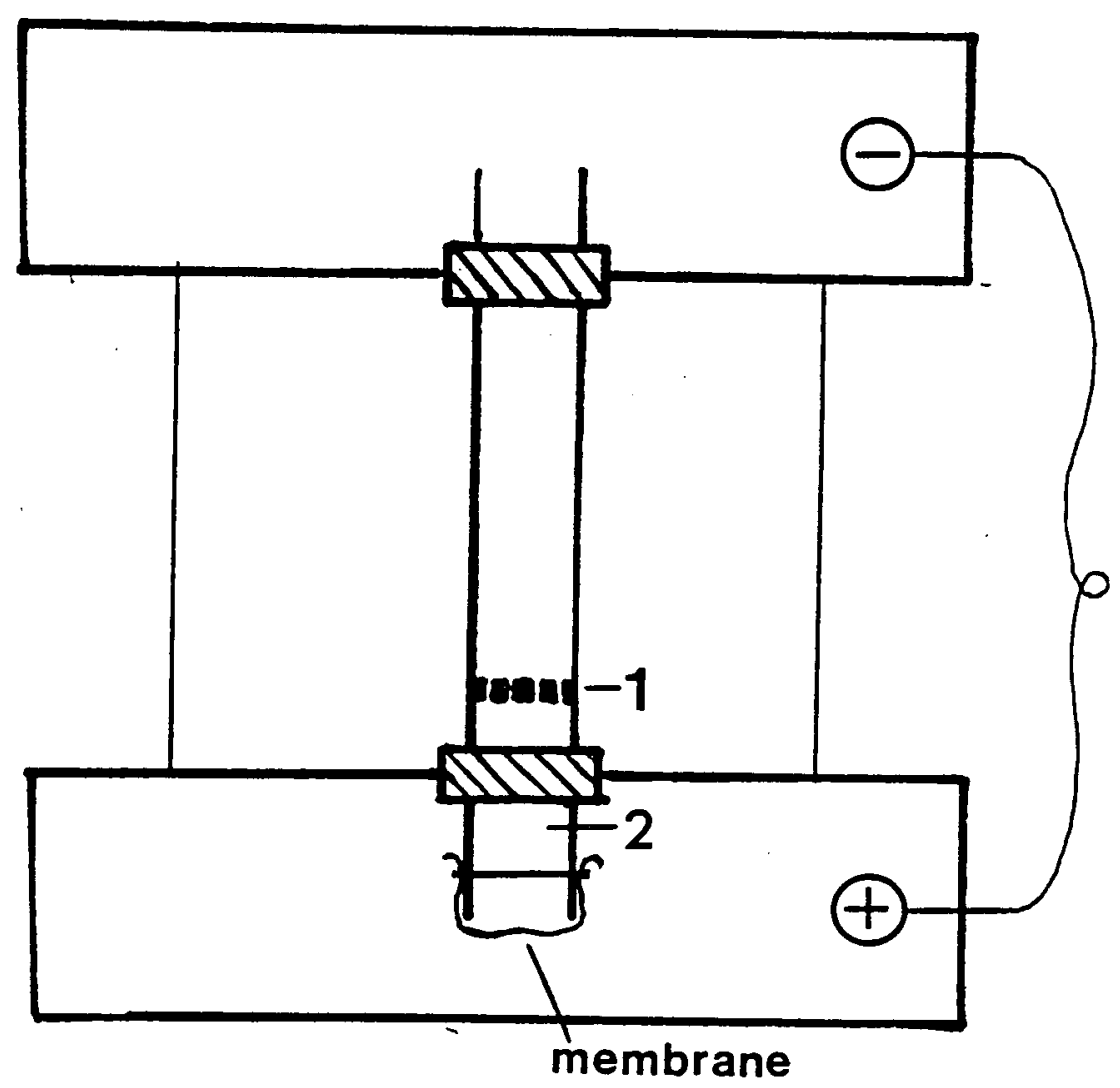


at $100 \mathrm{~V}$ for $2.5-3.0$ hours; a time sufficient to allow DNA to migrate from the agarose block and onto the dialysis membrane (D. M. McSorley, personal communmication). A brief period (2 minutes) of electrophoresis with reversed polarity was used to lift the DNA from the surface of the dialysis membrane. The DNA containing solution was removed from the reservoir (2) by syringe. The DNA was recovered by ethanol precipitation at $-20^{\circ} \mathrm{C}$ (see above).

2.61 Preparation of ${ }^{32} \mathrm{p}$ labelled DNA probes by nick translation The basic procedure of Rigby et al. (1977) was used. Approximately $1 \mu \mathrm{g}$ of the DNA to be labelled was recovered by ethanol precipitation, dried, and resuspended in 5 ul of $10 \mathrm{x}$ reaction buffer (10x: $0.5 \mathrm{M} \mathrm{Tris.} \mathrm{HCl}, 0.1 \mathrm{M} \mathrm{MgSO}_{4}$, $1 \mathrm{mM}$ dithiothreitol, $500 \mu \mathrm{g} / \mathrm{ml}$ bovine serum albumin), to which was. also added $5 \mu \mathrm{l}$ of each of the unlabelled nucleotides (from $200 \mu \mathrm{M}$ aqueous stock solutions): dCTP; dGTP and dATP (Sigma). An aliquot (2-6 $\mu$ l depending on activity) of $\left(\alpha-{ }^{32} P\right)$ dTTP (Amersham) was added to the reaction mixture and the volume adjusted to $50 \mathrm{\mu l}$ with $\mathrm{H}_{2} \mathrm{O}$. The reaction mixture was chilled, on ice, for 5 minutes before addition of $1 \mathrm{Hl}$ of a $10^{4}$ fold dilution (in $\mathrm{H}_{2} \mathrm{O}$ ) of the stock DNAase (Boehringer) preparation ( $1 \mathrm{mg} / \mathrm{ml}$ in $1 \mathrm{x}$ nick translation buffer containing $50 \%$ glycerol). This was followed by the immediate addition of $2 \mu l$ of $\underline{E}$. coli DNA polymerase I (Boehringer). The reaction was allowed to proceed at $15^{\circ} \mathrm{C}$.

The incorporation of ${ }^{32} \mathrm{p}$ into DNA was determined from $1 \mu \mathrm{I}$ samples taken at 20 minute intervals after the start of the reaction. Samples were spotted onto $\mathrm{GF} / \mathrm{C}$ filters and the radioactivity measured by the Cherenkov method in a Packiard 2425 liquid scintillation spectrometer. The filter was then washed in three changes of $200 \mathrm{ml}$ of $5 \%$ trichloroacetic acid. The washed filter was dried on a hot plate and the radioactivity measured as above. The percentage of ${ }^{32} \mathrm{P}$ 
incorporation into DNA was determined from the two values. Correction was also made for the background count (non-specific binding of $32 \mathrm{P}$ to the filter), which was measured for the reaction at time zero (before addition of DNAase or polymerase $I$ ). The reaction was terminated by the addition of $5 \mu \mathrm{l}$ of $0.2 \mathrm{M}$ EDTA. The labelled probe wa's stored (in the reaction mixture) at $-20^{\circ} \mathrm{C}$, and denatured by boiling for 5 minutes immediately before use.

$2.6 \mathrm{~m}$ Southern transfer, 'dot' blotting and filter hybridization

Southern transfer

The technique of Southern (1975) was used for the transfer and immobilization of DNA onto nitrocellulose filters for subsequent use in hybridization experiments. Fragments of DNA were separated by electrophoresis through $0.7 \%$ agarose gels (Section $2.6 j$ ). The gel was stained with ethidium bromide and photographed with a linear scale for later reference. The DNA was denatured by soaking the gel in $500 \mathrm{ml}$ of $0.5 \mathrm{M} \mathrm{NaOH} / 1.5 \mathrm{M} \mathrm{NaCl}$ for 1 hour at room temperature. The gel was rinsed in several volumes of $\mathrm{H}_{2} \mathrm{O}$ and then neutralized by soaking for 1 hour at room temperature in $500 \mathrm{ml}$ of $1 \mathrm{M} \mathrm{Tris.HCl}(\mathrm{pH} 8.0)$ and $1.5 \mathrm{M}$ $\mathrm{NaCl}$. The gel was rinsed in $200 \mathrm{ml}$ of $20 \mathrm{x}$ SSC ( $1 \mathrm{x}$ SSC: $0.15 \mathrm{M} \mathrm{NaCl}$, $0.015 \mathrm{M}$ sodium citrate) and then placed on a standard unidirectional blotting apparatus, presoaked in 20x SSC (e.g. Maniatis et al., 1982; Fig. 11.1). A piece of nitrocellulose filter (Schleicher and Schuell BA 85) was cut to size, pre-soaked in $20 x$ SSC, and positioned on top of the gel. The filter was covered by two pieces of pre-soaked (20x SSC) Whatman 3MM paper. A stack of dry paper towels was placed over the 3MM paper and weighted with approximately $1 \mathrm{~kg}$. The transfer buffer used was $20 \mathrm{x}$ SSC and the blotting process was allowed to proceed for at least 16 hours. At the end of this period the filter was rinsed by immersion in $6 \mathrm{x}$ SSC for 10 minutes at room temperature. 
The filter was then dried under vacuum for 2 hours at $80^{\circ} \mathrm{C}$, and stored under dessication at room temperature.

'Dot' blotting

The method of Kafatos et al. (1979) was used, as modified by D. M. McSorley (personal communication). All operations were carried out at room temperature. Different amounts of either $\underline{S}$. pombe total DNA or plasmid DNA were resuspended separately in a small volume of TE buffer. Samples, as required, were spotted and then dried onto the surface of a polythene sheet. The DNA was denatured by the addition of $10 \mu l$ of $0.3 \mathrm{NaOH}$, and then neutralised by the addition of $2 \mu l$ of 2M Tris.base $(\mathrm{pH} 8.0)$. The DNA samples were then spotted onto the surface of a presoaked (20x SSC) nitrocellulose filter. The DNA was immobilised onto the filter by vacuum drying at $80^{\circ} \mathrm{C}$ for 2 hours. The prepared filter was then hybridized using the same procedure as described below.

\section{Filter hybridization and autoradiography}

The baked filter was immersed carefully (so as to wet from beneath) in $40 \mathrm{ml}$ of prehybridization solution (2x SSC, $5 x$ Denhart's solution (see below), $50 \mu \mathrm{g} / \mathrm{ml}$ of denatured salmon sperm DNA, $0.5 \%$ SDS), contained in a glass staining dish. Prehybridization was carried out at $68^{\circ} \mathrm{C}$ for $3-4$ hours.

$$
\begin{gathered}
\text { Denhart's solution (50x) per } 500 \mathrm{ml} \mathrm{H}_{2} \mathrm{O} \text {; } \\
\text { Ficoll } 5.0 \mathrm{~g} \\
\text { polyvinylpyrollidone } 5.0 \mathrm{~g} \\
\text { BSA (Pentax Fraction V) } 5.0 \mathrm{~g}
\end{gathered}
$$

The filter was then placed in $40 \mathrm{ml}$ of fresh prehybridization buffer and the denatured probe (see above) was added; an overlay of paraffin was given to prevent evaporation. The container was sealed and hybridization was carried out under the conditions indicated in the 
text (section 7.4). After hybridization the filter was washed four times in $1 \mathrm{x} \mathrm{SSC}$ at $60^{\circ} \mathrm{C}$. The filter was then air dried between sheets of Whatman 3MM paper before autoradiography.

\section{Autoradiography}

The dried filter was taped to a sheet of Whatman 3MM paper and fitted into a standard autoradiography cassette. A sheet of X-ray film (Kodak X-Omat AR) was pre-flashed and placed against the filter. An intensifier screen (Du Pont Cronex-Lighting Plus) was placed in contact with the film. The cassette was sealed and the film exposed at $-70^{\circ} \mathrm{C}$ for $24-96$ hours. The film was developed for 5 minutes in Kodak LX-24 and fixed for 10 minutes in Kodak FX-40. 


\section{Chapter 3}

\section{ISOLATION OF BENOMYL RESISTANT COLD SENSITIVE MUTANTS}

\subsection{Sensitivity of the wild type strain to benomy}

The sensitivity of the wild type strain towards benomyl was investigated in order to determine a suitable concentration of the drug at which to select for resistant mutants. This assay was to be carried out at 35 and $20^{\circ} \mathrm{C}$ for the following reasons: firstly, selection for benomyl resistant mutants would be carried out at $35^{\circ} \mathrm{C}$ (Fig. 1.2); secondly, $20^{\circ} \mathrm{C}$ would serve as the restrictive temperature at which to screen the mutants for a cold sensitive (cs) cell division cycle ( $\underline{\mathrm{cdc}}$ ) defect, using $35^{\circ} \mathrm{C}$ as the permissive temperature.

A loopful of wild type $\left(972 \underline{h}^{-}\right)$cells from a freshly reisolated culture was streaked on to the surface of EMM agar containing one of the following concentrations of benomyl: $0,5,10,20,30,40,60$ or $80 \mu \mathrm{g} / \mathrm{ml}$. Two plates with each concentration of benomyl were inoculated. One from each pair was incubated at $35^{\circ} \mathrm{C}$, the other at $20^{\circ} \mathrm{C}$. Separate control plates consisting of EMM alone and EMM containing an amount of ethanol equivalent to that used for preparation of the highest benomyl concentration were similarly inoculated and incubated at both temperatures. Benomyl sensitivity was scored on the basis of: (1) bulk growth; (2) the ability of isolated cells to form colonies; and (3) the morphology of isolated cells. The results of this experiment are presented in Table 3.1 .

At both temperatures, bulk growth became progressively poorer with increasing benomyl concentration. Bulk growth was fully inhibited at $35^{\circ} \mathrm{C}$ in the presence of $30 \mu \mathrm{g} / \mathrm{ml}$ of benomyl. However, a slight inhibition of bulk growth was evident at $35^{\circ} \mathrm{C}$ even with $10 \mu \mathrm{g} / \mathrm{ml}$ 
Table 3.1 Effect of benomyl on the growth and morphology of the wild type strain (972h-) following three days incubation at 35 and $20^{\circ} \mathrm{C}$.

\begin{tabular}{|c|c|c|c|c|c|c|}
\hline \multirow[b]{2}{*}{$\begin{array}{c}\text { Concentration } \\
\text { of benomyl } \\
\mu \mathrm{g} / \mathrm{ml}\end{array}$} & \multicolumn{3}{|l|}{$35^{\circ} \mathrm{C}$} & \multicolumn{3}{|l|}{$20^{\circ} \mathrm{C}$} \\
\hline & Colony size & $\begin{array}{l}\text { Bulk }{ }^{2} \\
\text { growth }\end{array}$ & $\begin{array}{c}\mathrm{Cell}^{3} \\
\text { morphology }\end{array}$ & Colony size & $\begin{array}{l}\text { Bulk } \\
\text { growth }\end{array}$ & $\begin{array}{c}\text { Cell } \\
\text { morphology }\end{array}$ \\
\hline 0 & $2-3 \mathrm{~mm}$ & +++ & $\mathbf{N}$ & $0.5-1 \mathrm{~mm}$ & +++ & $\mathrm{N}$ \\
\hline 5 & $2-3 \mathrm{~mm}$ & +++ & N/A & N.P. & + & A \\
\hline 10 & $0.5-1 \mathrm{~mm}$ & ++ & $\mathrm{N} / \mathrm{A}$ & -N.P. & + & A \\
\hline 20 & N.P. & ++ & A & N.P. & 0 & A \\
\hline 30 & N.P. & 0 & A & N.P. & 0 & A \\
\hline 40 & N.P. & 0 & A & N.P. & 0 & A \\
\hline 60 & N.P. & 0 & A & N.P. & 0 & $A$ \\
\hline 80 & N.P. & 0 & A & N.P. & 0 & A \\
\hline +ethanol $(1.6 \%)$ & $2-3 \mathrm{~mm}$ & +++ & $\mathrm{N}$ & $0.5-1 \mathrm{~mm}$ & +++ & $\mathrm{N}$ \\
\hline
\end{tabular}

${ }^{1}$ Estimated diameter of isolated colonies; N.P. - none present.

${ }^{2}$ Bulk growth : scored in relation to growth of the wild type on EMM alone (+++ = maximal; $0=$ zero growth) at each respective temperature.

${ }^{3}$ Cellular morphology: $N=$ normal; $A=$ aberrant morphology (heterogeneous population containing swollen, branched and bent forms); $/ A=$ normal but some cells present with aberrant morphology. 
of the drug. In contrast, bulk growth in the presence of this concentration of benomyl at $20^{\circ} \mathrm{C}$ was very poor. Throughout the experiment and at both temperatures, bulk growth and colony formation on the EMM + ethanol plate was similar to that of the EMM control. Where observed, the inhibition of cell growth was therefore attributed solely to the toxic effect of benomyl.

Even with prolonged incubation (three days) at $35^{\circ} \mathrm{C}$, isolated colonies formed only in the presence of the two lowest benomyl concentrations tested. It was noticeable that, at $20^{\circ} \mathrm{C}$, isolated cells did not form even microscopic colonies in the presence of $5 \mu g / \mathrm{ml}$ of benomyl.

Microscopical examination revealed that isolated cells, when incubated with $30 \mu g / \mathrm{ml}$ of benomyl at $35^{\circ} \mathrm{C}$, were able to complete, at most, two cell divisions (data not shown). When incubated for several hours in the presence of 10 or $20 \mu \mathrm{g} / \mathrm{ml}$ of benomyl at 20 and $35^{\circ} \mathrm{C}$ respectively, cells became noticeably elongated. This phenomenon has also been documented by other workers to occur in cells of h

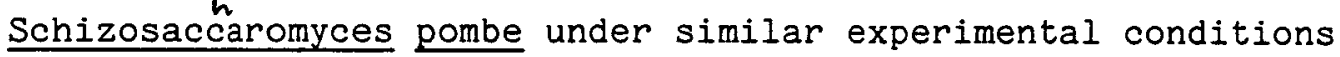
(Fantes, 1982; Walker, 1982). The elongation of cells in the presence of benomyl is consistent with the drug inducing a specific inhibition of division which, nevertheless, allows the continuation of cellular growth. Prolonged (2-3 days) incubation of cells at both temperatures in the presence of inhibitory concentrations of benomyl induced a variety of aberrant cellular morphologies (Table 3.1). Many cells assumed a T-shaped configuration, with the stem of the $T$ most often seen arising near the centre of the cell. Cells incubated in the presence of $5 \mu \mathrm{g} / \mathrm{ml}$ of benomyl at $35^{\circ} \mathrm{C}$ exhibited a normal morphology, although aberrant forms were occasionally observed (Table 3.1). In marked contrast, cells incubated with

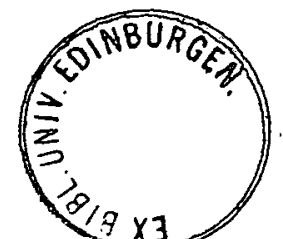


$5 \mathrm{\mu g} / \mathrm{ml}$ of benomyl at $20^{\circ} \mathrm{C}$ rapidly assumed a variety of aberrant morphologies. These observations indicate that $\underline{\underline{s}}$. pombe exhibits a temperature dependent sensitivity towards benomyl. Although this differential sensitivity was best seen at the lower drug concentrations tested, it is clear that cells are considerably more resistant (as judged by cellular morphology) to a given benomyl concentration at $35^{\circ} \mathrm{C}$ than at $20^{\circ} \mathrm{C}$.

3.2 Isolation of benomyl resistant cold sensitive cdc mutants

The rationale and experimental strategy behind the isolation of mutants with this dual phenotype is described in Chapter 1. Briefly (see also Fig. 1.2), benomyl resistant mutants isolated at the permissive temperature of $35^{\circ} \mathrm{C}$ were to be screened for a cold sensitive ( $\underline{c s}$ ) cell division cycle ( $\underline{c d c}$ ) defect on benomyl free medium at $20^{\circ} \mathrm{C}$. Consideration was given, with due reference to the results of the previous experiment, to the choice of a suitable benomyl concentration at which to select for resistant mutants. For instance, the frequency of mutants resistant to the higher concentrations of benomyl tested (Table 3.1) might be prohibitively low to allow adequate detection of $\underline{c s} \underline{c d c}$ mutants. Another possibility was that selection for mutants with a high level of benomyl resistance might select strongly for uptake mutants (Nachmias and Barash, 1976). On the other hand, the excessive background growth of cells present with the lower concentrations of benomyl tested (Table 3.1) would have made the unambiguous selection of resistant mutants difficult. In view of these reservations, it was decided to select for mutants resistant to $30 \mu \mathrm{g} / \mathrm{ml}$ of benomyl at $35^{\circ} \mathrm{C}$. At this drug concentration both colony formation and bulk growth are severely inhibited (Table 3.1). 
Five colonies of the wild type $\left(972 \underline{h}^{-}\right)$haploid strain were selected for mutagenesis. The colonies (designated A-E) were divided and each half (containing $2-3 \times 10^{6}$ cells) spread on to a separate EMM plate containing $30 \mu \mathrm{g} / \mathrm{ml}$ of benomyl. Nine of the ten plates were U.V. irradiated as described (Section 2.3b), the remaining plate was left unirradiated to act as a control. All of the plates were then incubated at $35^{\circ} \mathrm{C}$ for three days. After this time, resistant colonies were observed on all nine of the irradiated plates. No colonies were present on the control plate, thereby establishing that the mutants had arisen independently following U.V. irradiation. In total, 146 benomyl resistant colonies were obtained. These were picked and retested for growth at $35^{\circ} \mathrm{C}$ on EMM agar containing $30 \mu \mathrm{g} / \mathrm{ml}$ of benomyl; this step also served to purify the resistant isolates from any residual background growth. Replicates of the drug resistant isolates were made onto EMM agar containing the dye magdala red. A wild type control strain was included on each plate, and the replicates were then incubated at $20^{\circ} \mathrm{C}$ for three days. After this time, each isolate was scored, with reference to the wild type control, for bulk growth and the presence of elongated cells. Cells which became markedly elongated when transferred from 35 to $20^{\circ} \mathrm{C}$ were presumed, using the critélion discussed in the previous Chapter, to harbour a cs cdc defect.

\subsection{Identification and classification of cs cdc mutants}

The inclusion of the dye magdala red in the medium aided the identification of cold sensitive isolates, due to the high proportion of dead and dying cells within such isolates. In this respect, $\underline{c s} \underline{c d c}$ isolates were expected to stain deep red with the dye, contrasting with the whitish-pink colouration exhibited by 
Table 3.2 Phenotypic classification of benomyl resistant mutants following three days incubation at $20^{\circ} \mathrm{C}$.

$\begin{array}{ccccc}\begin{array}{c}\text { Number of } \\ \text { mutants }\end{array} & \begin{array}{c}\text { Bulk } \\ \text { growth } \\ 20^{\circ} \mathrm{C}\end{array} & \begin{array}{c}\mathrm{Cell}^{2} \\ \text { morphology }\end{array} & \begin{array}{c}\mathrm{MR}^{3} \\ \text { staining }\end{array} & \text { Class } \\ 38 & + & \begin{array}{l}2-3 \mathrm{x} \\ \text { wild type length }\end{array} & \text { dark red } & \mathrm{X} \\ 70 & ++ & \begin{array}{c}1.5 \mathrm{x} \\ \text { wild type length }\end{array} & \text { red } & \mathrm{Y} \\ 38 & +++ & \text { wild type length } & \begin{array}{c}\text { pink } \\ \text { (normal) }\end{array} & \mathrm{Z}\end{array}$

Total 146

${ }^{1}$ Bulk growth on EMM agar scored in relation to the growth of the wild type stain under the same conditions;

(+++ $=$ maximal $; 0=$ zero growth).

${ }^{2} \mathrm{Cell}$ morphology : degree of cellular elongation at $20^{\circ} \mathrm{C}$.

${ }^{3}$ MR staining : staining intensity of cells with magdala red. 
similarly stained colonies of wild type cells. On examination (Table 3.2 ), 26\% of the benomyl resistant mutants (designated Class $\mathrm{X}$ ) grew poorly at $20^{\circ} \mathrm{C}$ and stained intensely with magdala red, $48 \%$ of the isolates (Class $Y$ ) showed a substantial amount of growth (compared to the Class $X$ isolates) and stained less intensely with the dye. The remaining $26 \%$ of isolates (Class $Z$ ) were indistinguishable from the wild type on the basis of either bulk growth or magdala red staining. The majority of Class $X$ isolates were composed of strikingly elongated cells (Table 3.2). This phenotype is characteristic of the continuation of growth during a division block. Some Class X isolates appeared to exhibit a slightly less pronounced cde phenotype at $20^{\circ} \mathrm{C}$ (see Table 3.3). Nevertheless, the $38 \mathrm{Class} \mathrm{X}$ isolates examined were considered to show considerable phenotypic homogeneity. One Class X isolate proved to be an exception. Cells of isolate E12, although severely inhibited in growth at $20^{\circ} \mathrm{C}$, arrested with a short, club-shaped morphology. This phenotype is more consistent with a heat sensitive defect in cellular growth. Each Class Y isolate was also found to consist of elongated cells. However, elongation was only slight, and in all isolates of this class there appeared to be a continuation of cell division following prolonged incubation at $20^{\circ} \mathrm{C}$. The cells of Class $\mathrm{Z}$ isolates were indistinguishable in cell morphology at the restrictive temperature from cells of the wild type control strain.

It was considered that Class $X$ mutants would be of most value for subsequent characterisation. Consequently, a sample of fourteen mutants, broadly representative of the overall range of phenotypes observed in this class, were selected for further analysis (Table 3.3). Isolates were selected so as to include at least one representative from each of the five original colonies (A-E; Table 3.3) taken 
Table 3.3 Phenotypic characterisation of the fourteen Class $X$ benomyl resistant mutants selected for further analysis.

Strain ${ }^{1}$

isolation

number

\begin{tabular}{|c|c|c|c|}
\hline A4 & $\mathrm{R}$ & ++ & $\begin{array}{l}\text { partially } \\
\text { elongated }\end{array}$ \\
\hline A22 & $\mathrm{R}$ & + & $E$ \\
\hline B 18 & $\mathrm{R}$ & $+/++$ & $\begin{array}{l}\text { partially } \\
\text { elongated }\end{array}$ \\
\hline C 10 & $\mathrm{R}$ & $+/++$ & $\begin{array}{l}\text { partially } \\
\text { elongated }\end{array}$ \\
\hline $\mathrm{C} 23$ & $\mathrm{R}$ & + & $\mathrm{E}$ \\
\hline C29 & $\mathrm{R}$ & + & $E$ \\
\hline D1 & $R$ & + & $\begin{array}{l}\text { elongate } \\
\text { and branched }\end{array}$ \\
\hline D2 & $\mathrm{R}$ & + & $E$ \\
\hline D3 & $\mathrm{R}$ & + & $E$ \\
\hline D12 & $\mathrm{R}$ & $+/++$ & $\begin{array}{l}\text { partially } \\
\text { elongated }\end{array}$ \\
\hline D 15 & $\mathrm{R}$ & + & $E$ \\
\hline D 19 & $\mathrm{R}$ & + & $E$ \\
\hline D23 & $\mathrm{R}$ & + & $E$ \\
\hline E14 & $\mathrm{R}$ & + & $E$ \\
\hline 972 & $S$ & +++ & normal \\
\hline
\end{tabular}

Growth phenotype ${ }^{2}$

BEN30 $35^{\circ} \mathrm{C} \quad$ EMM $20^{\circ} \mathrm{C}$

$\mathrm{CeIl}^{3}$
morphology

partially

$E$

partially

partially

gated

${ }^{1}$ Strain isolation number : letter refers to original parental colony (see text).

${ }^{2}$ Growth phenotype : BEN $30=$ sensitivity towards $30 \mu \mathrm{g} / \mathrm{mI}$ of benomyl following two days incubation at $35^{\circ} \mathrm{C} ; \mathrm{R}=$ resistant; $\mathrm{S}=$ sensitive. EMM $20^{\circ} \mathrm{C}=$ bulk growth on EMM agar following three days incubation at $20^{\circ} \mathrm{C}$, scored in relation to growth of the wild type strain under the same conditions ( $+++=$ maximal; $0=$ zero growth).

${ }^{3}$ Cell morphology : $E=$ elongated (2-3x wild type length). 
for mutagenesis. This precaution was taken to ensure that the mutants arose independently following U.V. irradiation, and were not clonally derived from a mutation present prior to mutagenesis in one or more of the original colonies. Each of the selected Class X mutants was reisolated and four colonies from each isolate were tested for benomyl resistance and cold sensitivity as described above. With the exception of isolate D1 (Table 3.3), all of the mutants tested arrested at $20^{\circ} \mathrm{C}$ with an elongated cylindrical morphology. Cells of mutant $\mathrm{D} 1$ became elongated at $20^{\circ} \mathrm{C}$ but also showed extensive lateral branching. All fourteen mutants exhibited good growth and essentially normal morphology in the presence of $30 \mu \mathrm{g} / \mathrm{ml}$ of benomyl at $35^{\circ} \mathrm{C}$.

In summary, the results presented here confirm benomyl to be a rapid and potent inhibitor of cell division and colony formation in S. pombe (Fantes, 1982). Selection for benomyl resistance gave considerable enrichment for cells with a $\underline{c s} \underline{\text { cdc }}$ phenotype. For example, $74 \%$ of the benomyl resistant mutants tested (Class $\mathrm{X}+$ Class Y, Table 3.2) formed cells that showed restricted growth and increased elongation when incubated at $20^{\circ} \mathrm{C}$. Since the Class $\mathrm{X}$ mutants were found to exhibit the most pronounced cs cdc phenotype at the restrictive temperature, a collection of these mutants was chosen for further study. The following sections describe the genetical characterisation of these mutants. 


\section{Chapter 4}

\section{GENETICAL CHARACTERISATION}

\subsection{Introduction}

The benomyl resistant cold sensitive phenotype exhibited by the mutants described in the previous chapter may have been due to a single gene mutation. Alternatively, two or more mutations may have been responsible for the dual phenotype. In order to differentiate between these possibilities, each one of the fourteen Class $\mathrm{X}$ mutants (Table 3.3) selected for analysis was backorossed to the wild type strain of opposite mating type, and the meiotic segregation pattern of the mutant phenotypes monitored by tetrad analysis. However, initial difficulties were encountered in crossing these mutants to the wild type strain using the standard procedure (Gutz et al., 1974): microscopical examination of the mating mixture indicated that mutant and wild type strains were unable to conjugate. Successful mating and subsequent sporulation in these crosses was eventually achieved using a modified version of the standard procedure (see section $2.3 \mathrm{c}$ ). Application of this technique allowed the genetical characterisation of these mutants to proceed. The results obtained from this study are presented in the following sections.

\subsection{Meiotic segregation analysis of D2, D3 and C10}

Tetrad analysis of backcrosses to the wild type strain involving isolates D2, D3 and C10 (Table 3.3) showed that, in every case, cosegregation of benomyl resistance and cold sensitivity occurred in a regular 2:2 mutant:wild type fashion (Table 4.1). This segregation pattern established that both mutant phenotypes were conferred by a mutation in a single nuclear gene. 
Table 4.1 Genetical Analysis of Backcrosses involving C10, D2 and D3.

\begin{tabular}{|c|c|c|c|c|}
\hline \multirow[t]{2}{*}{ Strain } & \multirow[t]{2}{*}{ Phenotype ${ }^{1}$} & \multicolumn{3}{|c|}{$\begin{array}{l}\text { Cross } \\
\left.\times 975 \underline{h}^{+}\left(\underline{b e n}^{s}{ }^{c s}\right)^{+}\right)^{1}\end{array}$} \\
\hline & & $\begin{array}{l}\text { Number of asci } \\
\text { analysed }\end{array}$ & $\begin{array}{l}\text { Composition } \\
\text { of tetrad }\end{array}$ & Frequency \\
\hline $\mathrm{C} 10$ & $\underline{\text { ben }}^{r} \underline{\mathrm{cs}}^{-}$ & 108 & 2 ben $^{r} \underline{c s}^{-}: 2 \underline{b e n}^{s} \underline{c s}^{+}$ & 108 \\
\hline D2 & $\underline{\text { ben }}^{r} \underline{c s}^{-}$ & 10 & $2 \underline{\text { ben }}^{r} \underline{\mathrm{cs}}^{-}: 2 \underline{\mathrm{ben}}^{\mathrm{s}} \underline{\mathrm{cs}}^{+}$ & 10 \\
\hline D3 & $\underline{\text { ben }}^{r} \underline{c s}^{-}$ & 100 & $2 \underline{\text { ben }}^{r} \underline{c s}^{-}: 2 \underline{\text { ben }}^{s} \underline{c s}^{+}$ & 100 \\
\hline
\end{tabular}

(1) Phenotype: ben $^{r}$ resistant to $30 \mu \mathrm{g} / \mathrm{ml}$ of benomyl.

ben $^{\text {s }}$ sensitive to $30 \mu \mathrm{g} / \mathrm{ml}$ of benomyl.

cs $^{-}$cdc phenotype at $20^{\circ} \mathrm{C}$.

cs $^{+}$wild type cell morphology at $20^{\circ} \mathrm{C}$. 


\subsection{Reversion analysi:us of mutant D3}

Spontaneous revertants of mutant D3 which formed colonies on EMM agar following six days incubation at $20^{\circ} \mathrm{C}$, were recovered at a frequency of $2 \times 10^{-5}$. Forty three cold resistant ( $\underline{\mathrm{cS}}^{+}$) revertants of D3 were picked and tested for benomyl sensitivity at $35^{\circ} \mathrm{C}$, as well as for growth and cell morphology at $20^{\circ} \mathrm{C}$. All of the $\mathrm{cs}^{+}$revertants tested were clearly more sensitive to benomyl than the original D3 parent (Table 4.2). Five revertants were indistinguishable from the wild type strain on the basis of growth and cell morphology at $20^{\circ} \mathrm{C}$ and sensitivity to benomyl at $35^{\circ} \mathrm{C}$. One revertant exhibited, in addition to considerable benomyl sensitivity at $35^{\circ} \mathrm{C}$, a curious 'pseudohyphal' morphology when grown on EMM agar at either 35 or $20^{\circ} \mathrm{C}$ (Table 4.2). However, the poor growth of this revertant, even in the absence of benomyl, precluded a direct comparison of benomyl sensitivity between this revertant, mutant $D 3$ and the wild type strain. The remaining 37 revertants showed an intermediate level of benomyl resistance and cold sensitivity compared to the wild type and mutant D3. This latter group of revertants was phenotypically similar and may constitute a specific class of revertants. An important point to emerge from the analysis was that co-reversion of both mutant phenotypes was observed in each revertant examined. This observation supported the conclusion drawn from tetrad analysis that the benomyl resistant cold.sensitive phenotype expressed by mutant D3 was conferred by a single gene mutation.

\subsection{U.V. induced reversion of mutants D3 and C10}

U.V. mutagenesis was used to generate additional $\underline{\mathrm{cs}}^{+}$revertants from these two strains. One possibility was that the mutagenesis step might induce a different spectrum of revertants to those observed above. 
Table 4.2 Phenotypic characterisation of cold resistant revertants of mutant D3.

\begin{tabular}{|c|c|c|c|c|c|c|}
\hline \multirow{3}{*}{$\begin{array}{l}\text { Number of } \\
\text { revertants }\end{array}$} & \multicolumn{4}{|c|}{ EMM + benomyl ${ }^{1}(\mu g / m l)$} & \multicolumn{2}{|c|}{ EMM $20^{\circ} C^{2}$} \\
\hline & & & & & Bulk & Cell \\
\hline & 0 & 10 & 20 & 30 & growth & morphology \\
\hline 1 & + & + & 0 & 0 & + & Pseudohyphal \\
\hline 37 & +++ & ++ & ++ & 0 & ++ & $\begin{array}{l}1.5 \times \text { wild } \\
\text { type length }\end{array}$ \\
\hline 5 & +++ & ++ & + & 0 & +++ & Normal \\
\hline $\begin{array}{l}\text { Control } \\
\text { strains }\end{array}$ & & & & & & \\
\hline D3 & +++ & +++ & +++ & ++ & + & $\begin{array}{l}2-3 \times \text { wild } \\
\text { type length }\end{array}$ \\
\hline $972 \underline{h}^{-}$ & +++ & ++ & + & 0 & +++ & Normal \\
\hline
\end{tabular}

(1) EMM + benomyl: Bulk growth following two days incubation at $35^{\circ} \mathrm{C}$ on EMM containing the concentration of benomyl indicated. Bulk growth scored in relation to growth of wild type on EMM alone. (+++ maximal; 0 zero growth).

(2) EMM $20^{\circ} \mathrm{C}$ : Bulk growth and cell morphology following three days incubation on EMM agar at $20^{\circ} \mathrm{C}$. Bulk growth scored in relation to growth of wild type under same conditions. (+++ maximal; 0 zero growth). 
Cells of mutants $\mathrm{C} 10$ and D3 were spread thinly on EMM agar and irradiated with U.V. as previously described (section 2.3b). The mutagenesis plates were incubated at $20^{\circ} \mathrm{C}$ for six days to select for $\mathrm{cs}^{+}$revertants. The strong cold sensitive phenotype of mutant D3 (Table 4.2) made identification of $\mathrm{cs}^{+}$revertants relatively straightforward. Thirteen revertant colonies of D3 were picked and retested for growth at $20^{\circ} \mathrm{C}$ and sensitivity to benomyl at $35^{\circ} \mathrm{C}$. Ten of the D3 revertants examined were phenotypically indistinguishable from the wild type. The remaining three revertants grew well at $20^{\circ} \mathrm{C}$ but were as resistant to benomyl at $35^{\circ} \mathrm{C}$ as the parental $\mathrm{D} 3$ mutant.

The identification of $\mathrm{cs}^{+}$revertants from $\mathrm{C} 10$ was less clearcut due to the weaker cold sensitive phenotype exhibited by this mutant. After six days incubation at $20^{\circ} \mathrm{C}$ the $\mathrm{C} 10$ control (non-irradiated) plate contained a background of poorly growing micro-colonies (each colony $0.5-1.0 \mathrm{~mm}$ in diameter). Nonetheless, on each irradiated plate a number of large and vigorously growing colonies were seen against the poorly growing background of cells. Sixty one of these large $\mathrm{cs}^{+}$ colonies were picked and analysed phenotypically. Fifty four of the C10 revertants were as sensitive to benomyl at $35^{\circ} \mathrm{C}$ as the wild type. Two revertants from this group exhibited a heat sensitive (hs) phenotype when grown on EMM agar at $35^{\circ} \mathrm{C}$ in the absence of benomyl. Neither of these heat sensitive revertants expressed an elongated cylindrical cdc phenotype at the high temperature $\left(35^{\circ} \mathrm{C}\right)$. Rather, both revertants exhibited a short, slightly swollen morphology, a phenotype more consistent with a hs defect in cellular mass accumulation. The remaining seven $\mathrm{cs}^{+}$revertants of mutant $\mathrm{c} 10$, although showing normal growth at $20^{\circ} \mathrm{C}$, were as resistant to benomyl at $35^{\circ} \mathrm{C}$ as the parental C10 mutant. This provided another instance, along with the three U.V. induced revertants of $D 3$ examined, of the selective 
reversion of the $\underline{\mathrm{cdc}}^{-}$phenotype. This pattern was interesting since it represented a departure from the observation that the majority of the $\mathrm{CS}^{+}$revertants of $\mathrm{C} 10$ and $\mathrm{D} 3$ examined showed co-reversion of both mutant phenotypes.

The genetic basis of the D3 and C10 revertant strains was not examined further. It is likely however, that a proportion of the revertants observed represented either true back mutations or intragenic suppressor mutations of the original lesion. In addition, some of the revertants very probably carried an extragenic suppressor mutation. Indeed, an opportunity to analyse this latter class of suppressor mutation was provided by the genetical analysis of the remaining benomyl resistant cold sensitive mutants selected for study.

\subsection{Meiotic segregation analysis of A4, A22, B18, C29, D12, D19,}

\section{D23 and E14}

The data presented in the previous section established that the mutant phenotypes exhibited by strains C10, D2 and D3 were, in each case, conferred by a lesion in a single nuclear gene. A more complex segregation pattern was observed when tetrad analysis was performed on backcrosses involving isolates A4, A22, B18, C29, D12, D19, D23 and E14. In backcrosses to the wild type strain, each of these strains exhibited a similar segregation pattern; a detailed description of the results obtained for mutant D23 (Table 4.3) will serve as an example of the overall situation. observed in the other mutants. Mutant D23 was crossed to the wild type strain of opposite mating type, and several asci were dissected and analysed as before. Three phenotypic classes of tetrads, designated class A, B and C (Table 4.3), were recovered from this cross. Class A asci contained two wild type progeny and two progeny phenotypically indistinguishable from the original mutant isolates. Progeny recovered in these crosses which were 
Table 4.3 Genetical analysis of mutant D23.

Original backcross $\mathrm{D} 23 \underline{h}^{-}\left(\underline{\mathrm{ben}}^{\mathrm{r}} \underline{\mathrm{cs}}^{-}\right)^{\mathbf{a}} \times 975 \underline{h}^{+}\left(\underline{\mathrm{ben}}^{\mathrm{s}} \underline{\mathrm{cs}}{ }^{+}\right)^{\mathrm{a}}$

$t$

Phenotypic classification of tetrads

2 ben $^{s} \underline{c s}^{+}: 2$ ben ${ }^{r} \underline{c s}^{-}$(type II ${ }^{b}$ segregants)

Frequency Class

$2 \underline{\text { ben }}^{\mathrm{css}^{+}} \underline{\mathrm{c}}^{+} 2 \underline{\text { ben }}^{\mathrm{r}} \underline{\mathrm{cs}}^{-}$(type $I^{\mathrm{c}}$ segregants

2

A

2 ben $^{s} \underline{c s}^{+}: 1 \underline{b e n}^{r} \underline{c s}^{-}$(type I) : 1 ben $^{r} \underline{c s^{-}}$(type II) 11

B

C

Backcrossing of type I and type II segregants

Type II

$\begin{array}{cc}\text { Type II }\left(\underline{h}^{-}\right) \times & 975 \underline{h}^{+} \\ \text {Frequency } & \text { Class } \\ 2 & \text { A } \\ 2 & \text { B } \\ 2 & \text { C }\end{array}$

(a) Phenotypes as designated in Table 4.1

(b) Segregants phenotypically indistinguishable from the original
Type I

Type $I\left(\underline{h}^{-}\right) \times 975 \underline{h}^{+}$

Frequency Class

$0 \quad$ A

$4 \quad$ B

O C

Type I $\left(\underline{\underline{h}}^{+}\right) \times 972 \underline{\underline{h}}^{-}$

Frequency Class

$0 \quad \mathrm{~A}$

44 B

$0 \quad \mathrm{C}$

\footnotetext{
D23 isolate

(c) Segregants exhibiting an increased level of cold sensitivity

(c) Segregants exhibiting an increased
and benomyl resistance (see text).
} 
phenotypically indistinguishable from the original mutant parent were, in each case, designated Type II segregants (Table 4.3).

The second class of tetrads observed, Class B, also contained two wild type progeny and two phenotypically indistinguishable benomyl resistant cold sensitive progeny. However, the mutant progeny from Class B tetrads, designated Type I, exhibited increased cellular elongation and reduced bulk growth at $20^{\circ} \mathrm{C}$ compared to the Type II segregants. In addition, Type I segregants were slightly more resistant to benomyl at $35^{\circ} \mathrm{C}$ than Type II progeny.

The third and most frequent class of tetrads observed, Class $C$, contained two progeny indistinguishable from the wild type, and one each of the Type I and Type II progeny. Tetrad data obtained from backcrosses involving mutants A4, A22, B18, C29, D12, D19, D23 and E14 is presented in condensed form in Table 4.4 .

In order to differentiate in the text between the original mutant isolate and the Type I and Type II mutant progeny, the following nomenclature will be adopted:

a) Type I segregants identified with suffix (I) [e.g.A22(I); C29(I); D19(I); etc.].

b) Type II segregants identified with suffix (II) [e.g. A22(II); C29(II); D19(II); etc.]

c) Original parental mutant strains retain original nomenclature (e.g. A22; C29; D19; etc.).

The segregation pattern observed in these backcrosses raised the possibility that the dual mutant phenotype expressed by the original isolates was, in each case, conferred by more than one mutation. The genetic basis of this complex segregation pattern was investigated further in backcrosses involving Type I and Type II segregants of mutants A22, C29, D19 and D23 to the wild type strain. These mutants 
Table 4.4 Genetical analysis of benomyl resistant cold sensitive mutants.

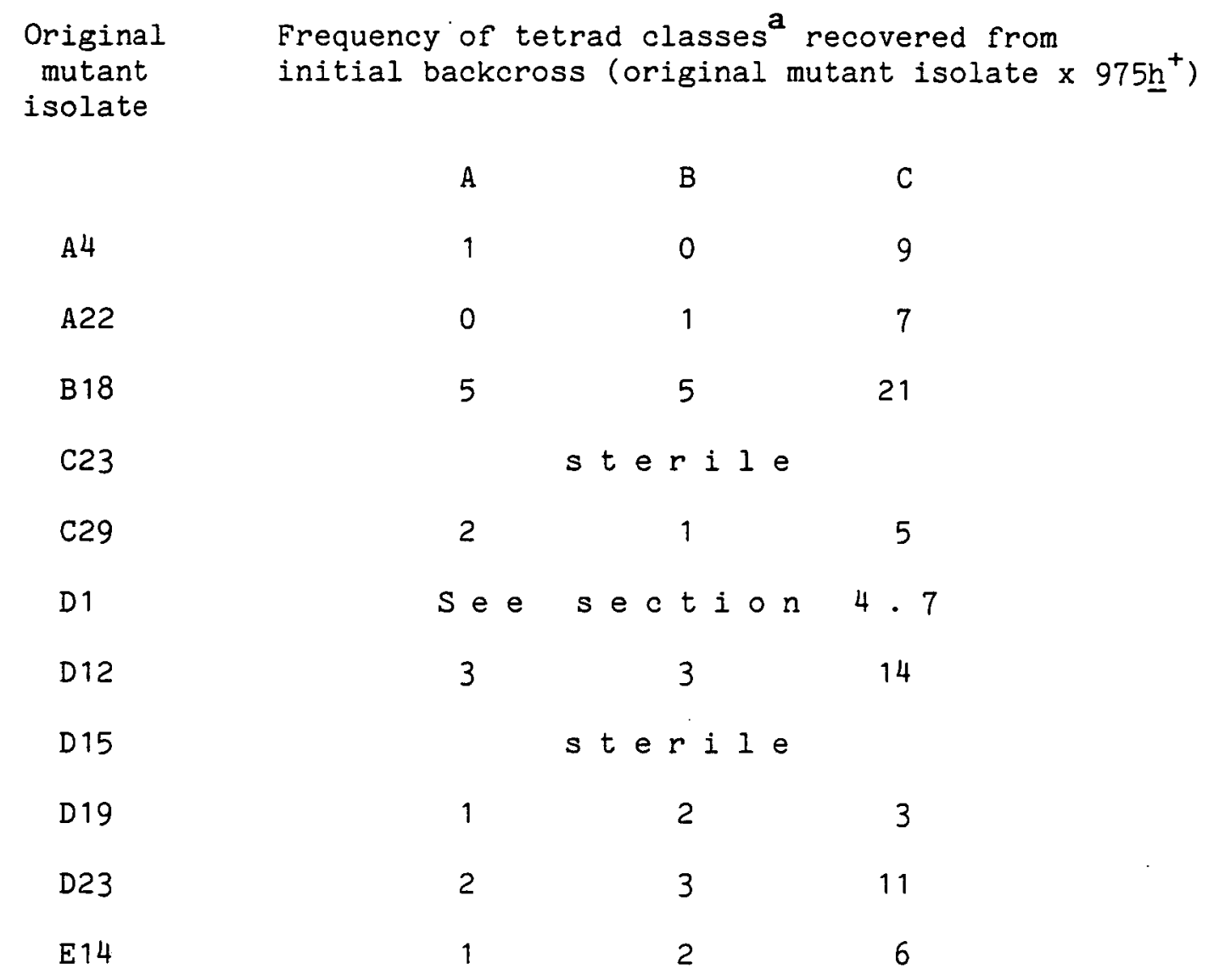

(a) Designation of tetrad classes given in Table 4.3 and text. 
were chosen for analysis since they were found to cross more readily than the other strains.

\subsection{Genetical analysis of Type I and Type II segregants of A22, C29,} D19 and D23

Type I and Type II segregants derived from each of these four isolates were crossed to the wild type strain of opposite mating type. Several asci were dissected from each cross, and the progeny analysed as before. Within each strain, Type I and Type II segregants showed different segregation patterns. Between strains, however, the overall segregation pattern exhibited by these segregants was similar for each isolate. The segregation pattern exhibited by Type I and Type II progeny of D23 will be used as a representative example of the situation observed in the other mutants. For ease of description, this information is given in the lower part of Table 4.3 as a continuation of the pedigree analysis of mutant D23. Pooled tetrad data describing the segregation pattern observed in backcrosses involving Type I and Type II segregants of the remaining mutants is given in Table 4.5 .

The cross between the D23 Type I segregants (D23(I)) and the wild type strain generated only Class B tetrads (Table 4.3): that is, tetrads containing two wild type and two Type I progeny. This segregation pattern was observed irrespective of the mating type combination used in the cross (Table 4.3). Similarly, only Class B tetrads were recovered from backcrosses involving the other Type I segregants tested (A22(I), C29(I) and D19(I), Table 4.5). Again, this pattern was observed irrespective of the mating type combination used (Table 4.5). In contrast, tetrads of Class A, B and C were recovered (Table 4.3) from backcrosses involving D23 Type II segregants (D23(II)). 
Table 4.5 Genetical analysis of backcrosses involving type $I$ and type II segregants of mutants A22, C29, D19, and D23.

Strain

A22
Type $I^{b}$ segregant

Type $I I^{\mathbf{b}}$ segregant
Frequency of tetrad class ${ }^{\mathbf{a}}$

B $A$ C

$\underline{\mathrm{h}}^{+} \times 972 \underline{\mathrm{h}}^{-}$

360

$17 \quad 0 \quad 0$
$\underline{h}^{-} \times 975 \underline{h}^{+}$
$2 \quad 1$
6

C29

Type I segregant

$\begin{array}{lrrr}\underline{\mathrm{h}}^{+} \times 972 \underline{\mathrm{h}}^{-} & 7 & 0 & 0 \\ \underline{\mathrm{h}}^{-} \times 975 \underline{\mathrm{h}}^{+} & 16 & 0 & 0\end{array}$

Type II segregant

$$
\underline{h}^{-} \times 975 \underline{h}^{+}
$$

0

21

D19

Type I segregant

$$
\begin{aligned}
& \underline{\mathrm{h}}^{+} \times 972 \underline{\mathrm{h}}^{-} \\
& \underline{\mathrm{h}}^{-} \times 975 \underline{\mathrm{h}}^{+}
\end{aligned}
$$

$0 \quad 0$

Type II segregant

$$
\underline{h}^{-} \times 975 \underline{h}^{+}
$$

1

D23

Type I segregant

$$
\begin{aligned}
& \underline{h}^{+} \times 972 \underline{h}^{-} \\
& \underline{h}^{-} \times 975 \underline{h}^{+}
\end{aligned}
$$

$\begin{array}{rll}44 & 0 & 0 \\ 4 & 0 & 0\end{array}$

Type II segregant

$$
\underline{\mathrm{h}}^{-} \times 975 \underline{\mathrm{h}}^{+}
$$

2 2

(a) Designation of tetrad classes given in Table 4.3 (see also text).

(b) Designation of Type I and Type II segregants given in the text (see also Table 4.3). 
The remaining Type II segregants analysed exhibited a similar segregation pattern to this in backcrosses (Table 4.5). This analysis established that the mutant phenotypes expressed by the Type I segregants $A 22(I), C 29(I), D 19(I)$ and $D 23(I)$ were, in each case, conferred by a mutation in a single nuclear gene. In addition, it was established from thosedata that each of the original parental mutants tested, as well as each of the respective Type II segregants, carried (in the simplest case) a secondary extragenic modifier mutation which partially suppressed both mutant phenotypes exhibited by the respective Type I segregants. The genetic basis of the modifier mutation in these strains was not examined further. The possibility therefore remains that the modifier mutation present in the various isolates might represent an independent and unlinked genetic lesion in each case. From the backcross data it was concluded that the modifier mutation present in isolates A22, C29, D19 and D23 was induced during mutagenesis and was not harboured in an unexpressed form in either of the wild type stocks $\left(972 \underline{h}^{-}\right.$and $\left.975 \underline{h}^{-}\right)$. Of interest was that progeny inferred to be carrying only the modifier mutation did not exhibit an observable mutant phenotype. The modifier was therefore considered to be a cryptic mutation since the presence of this element could only be determined through a modification of the Type I mutant phenotype. One possibility, not tested here, was that the complex segregation pattern exhibited by the remaining isolates (A4, B18, D12, E14) had a similar genetic basis to that described above.

\subsection{Meiotic segregation analysis of D1}

Mutant D1 exhibited a cold sensitive cdc phenotype very different from that of the other Class X mutants tested (Table 3.3): when 
incubated at $20^{\circ} \mathrm{C}$, this mutant attained an elongated and extensively branched morphology. Analysis of the backcross between D1 and the wild type strain (Table 4.6) revealed a segregation pattern reminiscent of that described for D23. Three phenotypic classes of tetrads, classes $D, E$ and $F$, were recovered from this backcross. Class $D$ tetrads (Table 4.6) contained two wild type progeny and two progeny (designated D1(II) segregants) phenotypically indistinguishable from the parental mutant. The second class of tetrads (Class E) also contained two wild type and two benomyl resistant cold sensitive progeny. The two mutant progeny in Class $E$ tetrads (designated D1(I) segregants) were phenotypically indistinguishable from each other, but were very different in morphology at $20^{\circ} \mathrm{C}$ compared to the $\mathrm{D} 1$ (II) segregants. Surprisingly, the $D 1(I)$ segregants exhibited an elongated cylindrical morphology at $20^{\circ} \mathrm{C}$ : a phenotype similar to that expressed by the Type I progeny described in Table 4.5. The D1(I) and D1(II) segregants, however, were indistinguishable from each other on the basis of benomyl sensitivity at $35^{\circ} \mathrm{C}$. The third class of tetrads observed (Class F) contained two wild type progeny and one each of the D1(I) and D1(II) type progeny.

The backcrosses between $D 1(I)$ segregants and the wild type strain generated only Class E tetrads (Table 4.6), irrespective of the mating type combination involved. In contrast, the cross between D1(II) segregants and the wild type strain generated tetrads of Class D, E and $F$ (Table 4.6). This data indicated that the mutant phenotypes of the $D 1(I)$ segregant were conferred by a mutation in a single nuclear gene. In addition, the original D1 mutant, as well as the D1(II) segregants, harboured an additional modifier mutation which altered specifically the $\underline{c d c}$ phenotype expressed by $D 1(I)$ segregants. Overall, the complex segregation pattern exhibited by isolate D1 was 
Table 4.6 Genetical analysis of mutant D1

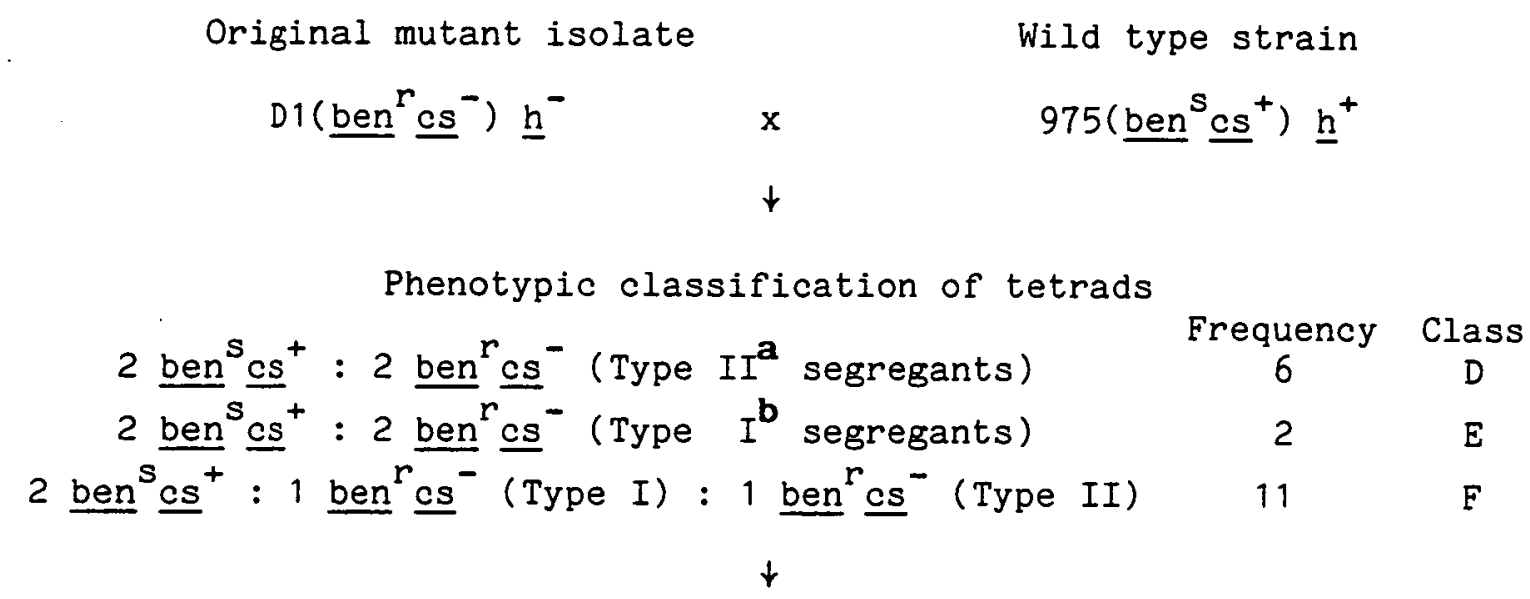

Backcrossing of Type I and Type II segregants

Type II

Type II $\left(\underline{h}^{-}\right) \times 975 \underline{h}^{+}$

Frequency Class

$\begin{aligned} 7 & \text { D } \\ 2 & \text { E } \\ 14 & \text { F }\end{aligned}$

Type II $\left(\underline{h}^{+}\right) \times 972 \underline{h}^{-}$

Frequency Class

$\begin{array}{ll}4 & D \\ 2 & \text { E } \\ 5 & \text { F }\end{array}$

Type I

Type $I\left(\underline{h}^{-}\right) \times 975 \underline{h}^{+}$

Frequency Class

O D

$5 \quad E$

O F

Type II $\left(\underline{h}^{+}\right) \times 972 \underline{h}^{-}$

Frequency Class

O D

$13 \quad E$

O F

(a) Segregants phenotypically indistinguishable from the original D1 isolate.

(b) Segregants phenotypically indistinguishable from the Type I segregants described in Table 4.3 (see also appropriate text). 
analogous to that described for D23. However, the presence of the modifier in mutant D1 induced, specifically, a branching in cellular morphology at $20^{\circ} \mathrm{C}$. The presence or absence of the modifier mutation did not visibly affect the level of benomyl resistance exhibited by this mutant. In view of this, it was not possible to discriminate between populations of $D 1(I)$ and $D 1(I I)$ cells either on the basis of bulk growth at $20^{\circ} \mathrm{C}$ or resistance to benomyl at $35^{\circ} \mathrm{C}$. Discrimination between these segregants was possible only from a microscopical examination of cellular morphology at $20^{\circ} \mathrm{C}$. This study highlights the importance of including a morphological examination of progeny in crosses involving temperature conditional cdc mutants. Observations made simply on the bulk growth of cdc progeny held at the restrictive temperature may overlook the presence of additional genetic elements which may confer subtle alterations in cellular morphology.

\subsection{Mutants C23 and D15}

These two mutants were considered to be sterile after repeated backcrossing to the wild type strain failed to produce zygotic asci or later stages of sporulation. Microscopical examination of the mating culture indicated that the primary cause of sterility in these mutants was most probably due to a defect in conjugation.

The genetical evidence gathered thus far demonstrated that in mutants D2, D3 and $\mathrm{C} 10$ and the modifier free (Type I) strains $A 22(I)$, C29(I), D1(I), D19(I) and D23(I) a single nuclear gene mutation was capable of conferring a benomyl resistant cold sensitive cdc phenotype. The majority of the subsequent genetical, physiological and cytological characterisation utilised these genetically well characterised strains. 
4.9 Intercrossing of mutants C10, D2, D3, A22(I), C29(I), D19(I)

and $\mathrm{D} 23(\mathrm{I})$

Intercrossing of the above strains was undertaken to test for possible allelism. Pairwise combinations of crosses were initially made between the mutants which exhibited a pronounced cold sensitive cde phenotype (D2, D3, A22(I), C29(I), D19(I) and D23(I)). No wild type segregants were recovered from any of the tetrads analysed (Table 4.7). Rather, each tetrad examined from the various intercross combinations was found to contain four phenotypically indistinguishable benomyl resistant cold sensitive progeny. These tetrads were therefore provisionally classified as parental ditypes. However, due to the similarity of mutant phenotypes exhibited by these strains, such a segregation pattern might have resulted from an ascus of homothallic origin. This condition arises, most usually, following a spontaneous switch of the $\underline{h}^{+}$mating type allele to the homothallic $\left(\underline{h}^{90}\right.$ ) form (Gutz et al., 1974). The population of $\underline{\mathrm{h}}^{90}$ benomyl resistant cold sensitive cells would then be competent to mate with surrounding cells of $\underline{h}^{90}, \underline{h}^{+}$or $\underline{h}^{-}$mating type. Typically, the following segregation pattern of mating types would be observed following these events.

cross heterothall
$\frac{\mathrm{h}^{+}}{\text {Homothallic }}{ }^{\frac{h^{9}}{1}}$

$$
\begin{array}{lll}
\underline{\mathrm{h}}^{90} \times \underline{\mathrm{h}}^{-} & \rightarrow & 2 \underline{\mathrm{h}}^{90}: 2 \underline{\mathrm{h}}^{+} \\
\underline{\mathrm{h}}^{90} \times \underline{\mathrm{h}}^{90} & \rightarrow & 4 \underline{h}^{90} \\
\underline{\mathrm{h}}^{90} \times \underline{\mathrm{h}}^{-} & \rightarrow & 2 \underline{h}^{90}: 2 \underline{h}^{-}
\end{array}
$$

In these intercrosses, tetrads considered to be of homothallic origin were identified using iodine vapours (section 2.3c). Progeny were replicated from the YEA master plate and onto MEA plates. The MEA 
Table 4.7 Analysis of intercrosses between benomyl resistant cold sensitive mutants

$\begin{array}{cccc}\begin{array}{c}\text { Mutant } \\ \text { strain }\end{array} & \text { C10 } & \text { D2 } & \text { D3 } \\ \text { C10 } & - & - & - \\ \text { D2 } & 10 & - & - \\ \text { D3 } & 32 & - & 2^{*} \\ \text { A22(I) } & 11 & 14 * & - \\ \text { C29(I) } & 10 & 5^{*} & 6^{*} \\ \text { D19(I) } & 30 & 11 * & 6^{*} \\ \text { D23(I) } & 11 & - & \end{array}$

Table indicates number of tetrads examined from each cross; all tetrads were parental ditypes. Insertions marked (*) have been corrected for asci of homothallic origin (see text). 
plates were then incubated at $30^{\circ} \mathrm{C}$ for three days. Progeny with an $\underline{h}^{90}$ mating type were readily identified by their spontaneous mating and sporulation characteristics under these conditions, thereby giving a strong positive staining reaction with iodine vapour. Using this procedure, only a low proportion (approximately 5\%) of the asci examined in these intercrosses were found to be of homothallic origin; these asci have been excluded from the intercross data presented in Table 4.7. Tetrads not of homothallic origin were duly considered to be true parental ditype (PD) asci. That only PD tetrads were obtained in these crosses indicated that the six mutants examined were very closely linked and were most probably allelic.

Mutant $\mathrm{C} 10$ has a less pronounced cold sensitive cdc phenotype than the other mutants (Table 3.3 ), and is therefore readily distinguishable from them. A C10 strain of appropriate mating type was crossed to each of the six remaining mutants. From each intercross combination at least ten tetrads were dissected and analysed (Table 4.7). The clear phenotypic difference between $\mathrm{C} 10$ and the other mutants made classification of tetrad types unambiguous. Only PD asci were recovered from each intercross combination involving C10 (Table 4.7). This evidence established that the mutants C10, D2, D3, A22(I), $C 29(I), D 19(I)$ and $D 23(I)$ mapped to a single genetic locus. This locus was designated ben 4 based on the primary phenotype of benomyl. resistance and to distinguish it from the loci ben 1,2 and 3 described by Yamamoto $(1980)$.

4. 10 Intragenic recombination between ben $4 . D 3$ and ben 4. C10

Random spore analysis (section $2.3 e$ ) was used to determine the frequency of recombination between the ben 4 alleles D3 and C10. Random spores from the cross ben $4 . C 10 \mathrm{x}$ ben $4 . D 3$ were spread onto EMM 
agar (approximately 300 per plate) and then incubated at $35^{\circ} \mathrm{C}$ for four days to allow colony formation. Isolated colonies were screened, via replica plating, for benomyl sensitivity at $35^{\circ} \mathrm{C}$, and cold sensitivity at $20^{\circ} \mathrm{C}$. Magdala red was included in the media for both selective conditions as an additional and rapid test for cell viability and ploidy (section 2.2a). Haploid wild type recombinants were identified on the basis of vigorous growth and normal morphology at $20^{\circ} \mathrm{C}$, and sensitivity to benomyl $(30 \mu \mathrm{g} / \mathrm{ml})$ at $35^{\circ} \mathrm{C}$. Seven haploid wild type recombinants were obtained from a sample of 6770 viable progeny screened. This frequency is equivalent to 1034 wild type recombinants per $10^{6}$ spores; a value which is similar to the figure of 500 wild type recombinants per $10^{6}$ spores given by Nurse et al. (1976) as being the upper value for intragenic recombination in $\underline{S}$. pombe.

\subsection{Linkage analysis of ben4 to other loci}

The seven ben 4 mutants chosen for detailed genetical characterisation (C10, D2, A22(I), C29(I), D19(I), D23(I)) exhibited two main mutant phenotypes: resistance to benomyl at the permissive temperature, and a cold sensitive defect in cell cycle progress. Subsequent physiological characterisation (Chapter 5) established that each of these mutants expressed a cold sensitive mitotic defect at $20^{\circ} \mathrm{C}$. A series of crosses was examined, largely by tetrad analysis, between several of these ben 4 mutants and existing mutants of $\underline{S}$. pombe with a broadly similar phenotype. Of particular interest in this respect were mutants whose properties included benzimidazole carbamate drug resistance and/or a temperature conditional mitotic defect. Analysis of such crosses would allow the detection of allelism between ben 4 and the other loci tested. In addition, the phenotypic properties of double mutant progeny recovered from these crosses might provide clues 
as to the possible interaction between mutant gene products. The three classes of mutants considered to be of most importance in this study were: (1) ben 1, 2 and 3 mutants; (2) cdc and wee mutants; and (3) nda mutants and $K M$ strains. The genetical analysis of ben 4 with each of these mutant classes is described in the following sections. 4.11a Linkage testing to ben 1,2 and 3 mutants

Mutations in these three loci were identified on the basis of conferring resistance to the antimitotic benzimidazole carbamate drug thiabendazole (TBZ) (Yamamoto, 1980). Strains carrying the ben 1 mutant allele also show strong cross resistance to $\mathrm{MBC}$ (the active component of benomyl), whereas ben2 and ben 3 mutant strains are only weakly resistant to this compound (Yamamoto, 1980). As a prerequisite to the genetical analysis, a comparison of sensitivity towards TBZ and $M B C$ was made between two ben 4 mutants (D3 and $C 10$ ) and strains carrying representative alleles of either ben 1, 2 or 3 . Since these latter mutants were originally isolated on a complex (YPD) medium containing TBZ, sensitivity testing was carried out using both a minimal (EMM) and a complex (YPD) medium containing different concentrations of either TBZ or MBC. The results from these sensitivity tests are presented in Table 4.8 .

The relative level of sensitivity of the wild type $\left(972 h^{-}\right)$and of the ben 1,2 and 3 mutant strains to $T B Z$ and $M B C$ was similar to that described in the original report of Yamamoto (1980). However, the slight differences in the absolute levels of sensitivity exhibited by these strains (Table 4.8 ) were attributed to a combination of four factors: (1) the representative alleles of ben 1, 2 and 3 (JY16, JY30 and JY25 respectively) were not those described in Yamamoto's original report (1980); (2) trace impurities contaminating the drugs may have had a significant effect; (3) the semi-quantitative method used for 
Table 4.8 Sensitivity of ben $1,2,3$ and 4 mutants to MBC and TBZ

$$
\mathrm{MBC}^{1}
$$

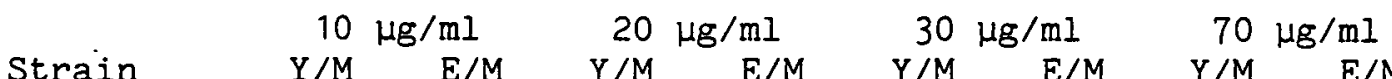

\begin{tabular}{|c|c|c|c|c|c|c|c|c|}
\hline $972 \underline{h}^{-}$ & ++ & ++ & + & + & 0 & 0 & 0 & 0 \\
\hline ben $4 . C 10$ & +++ & +++ & +++ & +++ & ++ & ++ & + & + \\
\hline ben 4.03 & +++ & +++ & +++ & +++ & ++ & ++ & + & + \\
\hline ben 1 .JY 16 & +++ & +++ & +++ & +++ & +++ & +++ & +++ & +++ \\
\hline ben 2. JY 30 & +++ & +++ & ++ & ++ & + & 0 & 0 & 0 \\
\hline ben 3. JY25 & +++ & +++ & ++ & ++ & + & 0 & 0 & 0 \\
\hline
\end{tabular}

\section{$\mathrm{TBZ}^{1}$}

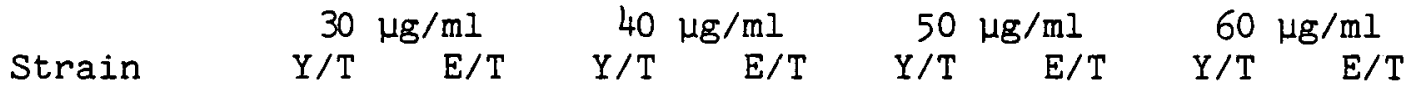

\begin{tabular}{|c|c|c|c|c|c|c|c|c|}
\hline $972 \underline{h}^{-}$ & +++ & +++ & ++ & + & + & 0 & 0 & 0 \\
\hline ben $4 . C 10$ & +++ & +++ & ++ & ++ & + & + & $0 /+$ & $0 /+$ \\
\hline ben $4 . D 3$ & +++ & ++ & ++ & + & + & 0 & 0 & 0 \\
\hline ben 1 . JY 16 & +++ & +++ & +++ & +++ & +++ & +++ & +++ & ++ \\
\hline ben $2 . J Y 30$ & +++ & +++ & +++ & +++ & ++ & + & ++ & + \\
\hline sen $3 . J Y 25$ & +++ & +++ & +++ & ++ & ++ & + & ++ & + \\
\hline
\end{tabular}

(1) Bulk growth following three days incubation at $35^{\circ} \mathrm{C}$ on YPD or EMM agar containing either MBC or TBZ at the concentration indicated. Growth scored in relation to growth of wild type on either EMM or YPD agar respectively under the same conditions but in the absence of drugs.

$Y / T-Y P D+T B Z ; E / T-E M M+T B Z ; Y / M-Y P D+M B C ; E / M-E M M+M B C$. 
scoring growth may have made the exact comparison of results difficult and, (4) differences in media and growth conditions may have contributed to the variation. Several points important for the genetical analysis emerged from the data presented in Table 4.8. The ben 1 mutant exhibited a high level of resistance to $\mathrm{MBC}$ and $\mathrm{TBZ}$, growing well on either EMM or YPD agar containing the maximum concentration of these drugs tested. Mutants ben2.JY30 and ben3.JY25, when grown on EMM or YPD agar, were both resistant to $60 \mu \mathrm{g} / \mathrm{ml}$ of $\mathrm{TBZ}$; however, both mutants showed slightly better browth on the complex medium at this drug concentration. In contrast, ben2.JY30 and ben $3 . J Y 25$ showed only weak cross resistance to $M B C$ when the drug was included in either complex or minimal medium.

The growth of the wild type strain was fully inhibited, regardless of media composition, with 30 and $60 \mu \mathrm{g} / \mathrm{ml}$ of $\mathrm{MBC}$ and $\mathrm{TBZ}$ respectively. The ben 4 mutants $C 10$ and D3 grew well in the presence of $30 \mu g / m l$ of $M B C$ when the drug was included in either medium. From this, the ben 4 mutants tested were considered to express a level of $M B C$ resistance intermediate between that of the ben 1 (strong resistance) and the ben 2 and ben3 (weak resistance) mutants. Mutant ben 4.010 showed weak cross resistance to $60 \mu \mathrm{g} / \mathrm{ml}$ of $\mathrm{TBZ}$ when grown on EMM or YPD agar. However, mutant ben $4 . D 3$ was slightly more sensitive to TBZ than the wild type strain when grown on EMM agar.

A representative allele of ben 1 (JY16) was crossed to ben $4 . D 3$ and ben 4.C10 and several asci were dissected and analysed. The segregation of the ben 4 allele in these crosses was followed by scoring cellular elongation at $20^{\circ} \mathrm{C}$ and resistance to $\mathrm{MBC}$ and $\mathrm{TBZ}$ at $35^{\circ} \mathrm{C}$. Segregation of the ben 1 allele was determined from the high level of resistance to both $M B C$ and $T B Z$. The tetrad class data given in Table 4.9 shows that ben 1 and ben 4 are not closely linked. The double mutant 
ben $4 . C 10$ ben 1 was indistinguishable from the ben 1 parent on the basis of sensitivity to $M B C$ and $T B Z$ at $35^{\circ} \mathrm{C}$. When grown at $20^{\circ} \mathrm{C}$ in the absence of benomyl this double mutant exhibited a cold sensitive cdc phenotype similar to that of the ben4.C10 parent. The double mutant ben $4 . \mathrm{D} 3$ ben1, although resistant to at least $30 \mu \mathrm{g} / \mathrm{ml}$ of $\mathrm{MBC}$ at $35^{\circ} \mathrm{C}$, was only slightly more resistant to TBZ than the ben4.D3 parent. This double mutant strain also expressed a cold sensitive cdc phenotype at $20^{\circ} \mathrm{C}$ similar to that of the ben $4 . D 3$ parent. This indicated that the ben $4 . D 3$ allele partially suppresses the TBZ resistant phenotype of ben 1 mutants. In contrast, the ben 4.010 allele had little or no effect on the drug resistance phenotype conferred by this mutation.

Wild type recombinant progeny showing normal sensitivity to TBZ and $M B C$ were also recovered at high frequency from crosses of ben 4 mutants D3 and C10 with ben2.JY30 and ben3.JY25 (Table 4.9). In these crosses it was possible to identify the ben $4 . D 3$ and ben $4 . C 10$ progeny on the basis of $M B C$ resistance and cold sensitivity. The ben2 and ben3 parental types were scored on the basis of good growth on YPD containing $60 \mathrm{\mu g} / \mathrm{ml}$ of TBZ: mutants ben4.D3 and C10 grew less well under these conditions (Table 4.8). Discrimination between ben 4 ben2 and ben 4 ben $^{+}$mutants, as well as between ben 4 ben 3 and ben 4 ben $3^{+}$ mutants was complicated by the relatively low level resistance of the ben 2 and ben 3 mutants towards MBC and TBZ. Nevertheless, the double mutant progeny in each case were inferred from careful reference to the other segregant types of the tetrad, as well as to the wild type and parental controls. The double mutants ben $4 . D 3$ ben2 and ben 4.03 ben3 were both slightly more sensitive to TBZ than the parental strain ben4.D3. Both of these double mutants also expressed a cold sensitive cdc phenotype. The cellular morphology of the ben4.D3 ben2 double mutant was aberrant under these conditions, including branched and 
Table 4.9 Analysis of crosses between ben 1, 2, 3 and the benomy 1 resistant cold sensitive mutants ben $4 . C 10$ and D3.

ben $1 . J Y 16$

PD

NPD

TT

$x$ ben $4 . C 10$

1

1

9

$x$ ben $4 . D 3$

0

0

6

ben2. JY30

$\begin{array}{llll}\mathrm{x} \text { ben } 4 . \mathrm{C} 10 & 5 & 0 & 2 \\ \mathrm{x} \text { ben } 4 . \mathrm{D} 3 & 4 & 1 & 2\end{array}$

ben $3 . J Y 25$

$x$ ben $4 . C 10$

4

2

3

$x$ ben4.D3

5

1

1 
curved cell types. The double mutants ben $4 . C 10$ ben2 and ben $4 . C 10$ ben 3 both expressed a cold sensitive cdc phenotype at $20^{\circ} \mathrm{C}$, and both double mutants were also slightly more resistant to TBZ than the ben $4 . C 10$ parent. These crosses showed that there was neither allelism nor close linkage between ben 4 and ben 1,2 and 3 .

4.11b Linkage testing to cdc and wee mutants

The observation (discussed more fully in Chapters 5 and 6) that the ben 4 mutants under study here exhibited a mitotic defect at $20^{\circ} \mathrm{C}$ raised the possibility of allelism between ben 4 and one of the existing cdc genes controlling steps in the cell cycle in or close to mitosis. A series of crosses was therefore analysed between several ben 4 and cdc mitotic mutants. As a byproduct of this analysis it was expected to obtain various ben 4 cdc double mutant progeny which would exhibit a heat sensitive ( $\underline{\text { hs }}$ ) and a cold sensitive (cs ) cde phenotype at 35 and $20^{\circ} \mathrm{C}$ respectively. Such double mutants were considered to be of potential value for analysing interactions between ben $^{+}$and $\underline{\mathrm{cdc}}^{+}$gene products.

Mutants ben $4 . D 3$ and $C 10$ were crossed to each one of the following cdc mutants defective in mitosis at $35^{\circ} \mathrm{C}: 1.7,2.33,6.23,13.117$, 25.22, 27.K3 and 28.P8 (Nurse et al., 1976; Nasmyth and Nurse, 1981; Fantes, 1979). Also included in this analysis was the mitotic control mutant wee 1.6 (Thuriaux et al., 1978). Prior to use in genetical analysis the cdc and ben 4 mutants were tested for benomyl sensitivity at 20 and $25^{\circ} \mathrm{C}$. In addition, the bulk growth and celiular morphology exhibited by these mutants following incubation at 20 and $30^{\circ} \mathrm{C}$ on minimal medium was monitored. It was considered that information obtained from these experiments would be useful for the identification of an intermediate temperature which would permit the successful sporulation of ben $4 /$ cdc zygotes and which would also allow subsequent 
outgrowth of ben 4 cdc double mutant progeny. The results of these experiments are presented in Table 4.10. All of the cdc and the wee strains tested were as sensitive to benomyl at 20 and $25^{\circ} \mathrm{C}$ as the wild type strain, and each cdc mutant was found to exhibit normal growth and morphology at $20^{\circ} \mathrm{C}$ in the absence of benomyl. Mutants cdc 2.33 and $28 . P 8$ grew normally at $30^{\circ} \mathrm{C}$ on benomyl free medium. The mutants cdc $25.22,27 . K 8$ and 13.117 , however, formed but small colonies following prolonged incubation at $30^{\circ} \mathrm{C}$, and the bulk growth of these mutants was less pronounced than that of the wild type under these conditions. At $30^{\circ} \mathrm{C}$, cdc25.22 and cdc $27 . \mathrm{K} 3$ exhibited normal cellular morphology, whereas cdc13.117 cells became noticeably elongated at this temperature. The remaining two mutants, cdc 1.7 and 6.23 , exhibited a cdc phenotype at $30^{\circ} \mathrm{C}$ : in both cases the cells became markedly elongated and colonies were unable to form. The ben 4 mutants D3, A22(I), C29(I), $D 19(I)$ and $D 23(I)$ exhibited a partial cdc defect even at $30^{\circ} \mathrm{C}$ : the cells became elongated, but small colonies eventually formed following prolonged incubation. Mutant ben $4 . C 10$ on the other hand grew normally at $30^{\circ} \mathrm{C}$.

In crosses between the ben 4 mutants and the cde and wee strains successful sporulation and subsequent outgrowth of double mutant progeny was, in most cases, achieved at either 27 or $30^{\circ} \mathrm{C}$. The tetrad class data from this series of crosses is presented in Table 4.11. Taken overall, the results show that free recombination occurs between the ben 4 locus and each of the cdc and wee loci tested. Spore viability was poor in several of these crosses due to the failure of certain parental and/or ben 4 cdc double mutant progeny to grow at the intermediate temperatures tested. Crosses in which ben 4 cdc double mutant progeny were not recovered are shown in Table 4.11. In crosses of poor viability, tetrad class data was obtained by reference to the 


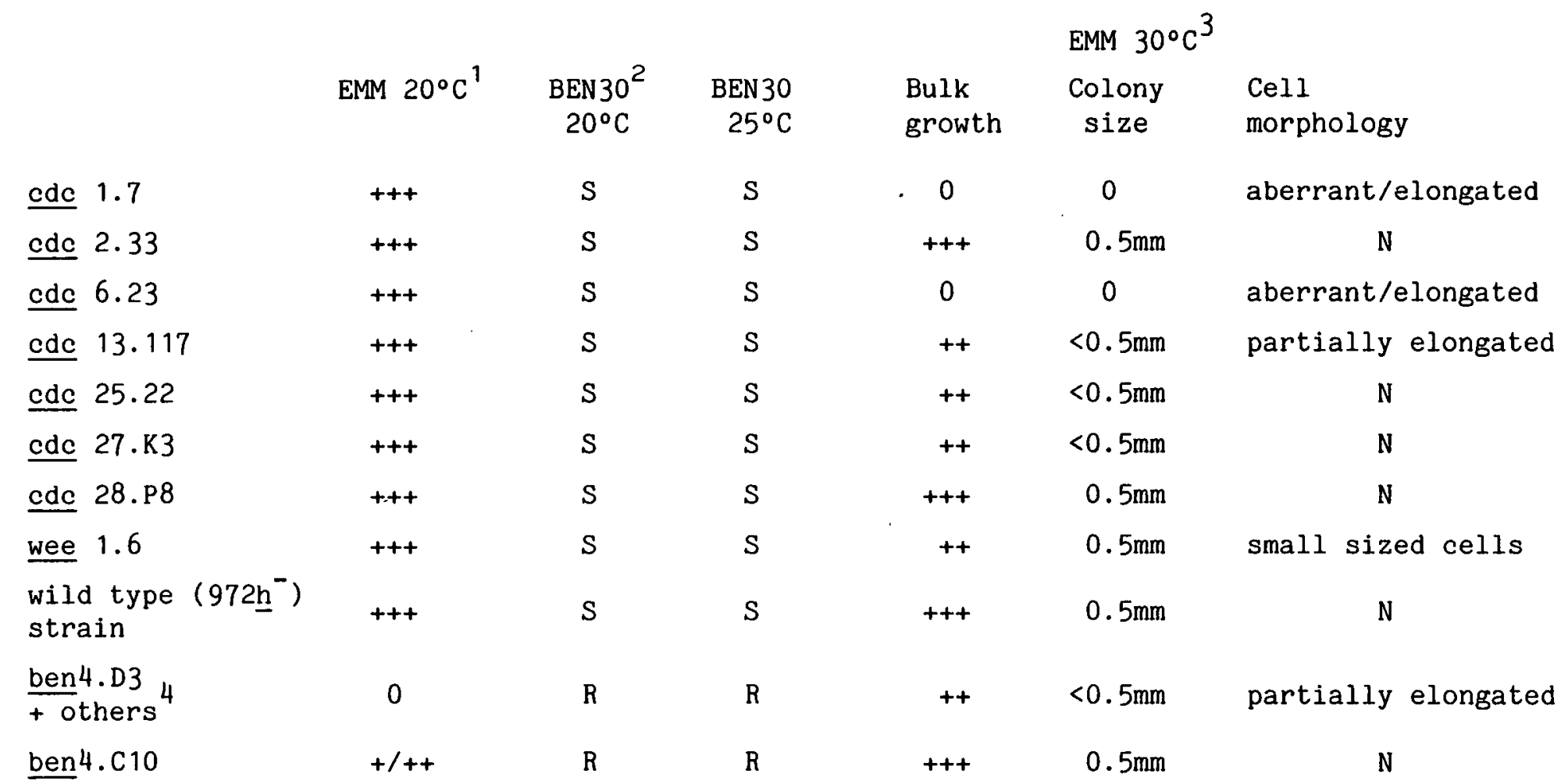

(1) EMM $20^{\circ} \mathrm{C}$ : bulk growth on EMM agar following three days incubation at $20^{\circ} \mathrm{C}$. Growth scored in relation to the growth of the wild type strain under the same conditions (+++ maximal; 0 zero growth).

(2) BEN30 : phenotype following three days incubation on EMM agar containing $30 \mu g / \mathrm{ml}$ of benomyl; $S$ - cells exhibit wild type sensitivity to benomyl, $\mathrm{R}$ - resistant; cells exhibit cdc ${ }^{-}$phenotype.

(3) EMM $30^{\circ} \mathrm{C}$ : bulk growth on EMM agar following three days incubation at $30^{\circ} \mathrm{C}$. Growth scored in relation to the growth of the wild type strain under the same conditions (+++ maximal; 0 zero growth). Colony size - estimated size of isolated colonies.

(4) Other mutants : D2, A22(I), C29(I), D19(I) and D23(I). 
viable progeny of the tetrad. The only viable progeny recovered from the cross ben $4 . D 23 \times$ cdc6.23 were wild type recombinants. These progeny were recovered at a frequency of $21.8 \%$ from the total number of spores analysed, this established that ben 4 and cdc6 were not closely linked.

Double mutant progeny were recovered from crosses between certain ben 4 mutants and the following cde mutants: $2.33,13.177,27 . \mathrm{K} 3$ and 28.P8. Double mutants of the form ben4.C10 cdc grew well and were able to form colonies at $30^{\circ} \mathrm{C}$. However, ben 4 cdc double mutants containing either ben4.D3, D19(I) or D23(I) grew poorly at $30^{\circ} \mathrm{C}$ and formed colonies only after prolonged incubation. This latter group of double mutants exhibited a striking curvature in cell morphology (designated 'curly' in Table 4.11) when incubated at $35^{\circ} \mathrm{C}$. A cytological description of this curious morphology is presented in section 6.9 .

An interaction of interest was observed in the ben $4 . C 10$ cdc 13.117 double mutant. At $20^{\circ} \mathrm{C}$, ben $4 . \mathrm{C} 10$ cdc 13.117 cells became strikingly elongated: cells of the ben $4 . C 10$ single mutant expressed only partial elongation under these conditions (Table 3.3). In contrast, at $35^{\circ} \mathrm{C}$, the ben $4 . C 10$ cdc 13.117 double mutant and the gate+3.13 single mutant exhibited a similar cdc phenotype. The limited tetrad class data presented in Table 4.11 shows that free recombination also occurred between ben 4 and the mitotic control mutant wee 1.6 . Cells of the ben4.D19(I) wee 1.6 double mutant exhibited both small size and resistance to benomy $(30 \mu \mathrm{g} / \mathrm{ml})$ at $35^{\circ} \mathrm{C}$. At $20^{\circ} \mathrm{C}$, this double mutant exhibited a poor bulk growth and the cells attained an elongated morphology, albeit less pronounced than the ben4.D19(I) parent. 
Table 4.11 Genetical analysis of crosses between ben 4 mutants and a collection of $\underline{c d c}$ and wee mitotic mutants.

Cross
PD
NPD
TT
Notes $^{1}$

cde 1.7
$x \frac{\text { ben } 4 . D 19(I)}{\text { ben } 4 . D 23(I)}$
3
0
4
N.D.
$x$ ben $4 . D 23(I)$
$0 \quad 4$
N.D.

cdc 2.33

$\begin{array}{llllr}x \text { ben } 4 . C 10 & 1 & 0 & 8 & D \\ x \text { ben } 4 . D 3 & 2 & 6 & 4 & \text { D/C } \\ x \text { ben } 4 . D 23(I) & 0 & 0 & 6 & \text { D/C } \\ x \text { ben } 4 . D 19(I) & 3 & 1 & 6 & \text { N.D. }\end{array}$

cdc 6.23

ben4.D23(I) Only wild type segregants recovered

cdc 13.117

$\begin{array}{lllll}x \text { ben } 4 . C 10 & 3 & 1 & 9 & D \\ x \text { ben } 4 . D 3 & 2 & 0 & 4 & \text { N.D. } \\ x \text { ben } 4 . D 19(I) & 2 & 1 & 4 & \text { D/C }\end{array}$

cdc 25.22

$\begin{array}{lllrl}x \text { ben } 4 . C 10 & 5 & 2 & 21 & \text { N.D. } \\ x \text { ben } 4 . D 3 & 2 & 0 & 2 & \text { N.D. } \\ x \text { ben } 4 . D 19(I) & 3 & 0 & 2 & \text { N.D. }\end{array}$

cdc $27 . \mathrm{K} 3$

$\begin{array}{llllr}\mathrm{x} \text { ben4.C10 } & 1 & 3 & 2 & \mathrm{D} \\ \mathrm{x} \text { ben } 4 . \mathrm{D} 3 & 1 & 2 & 0 & \mathrm{D} / \mathrm{C} \\ \mathrm{x} \text { ben } 4 . \mathrm{D} 23(I) & 2 & 0 & 6 & \mathrm{D} / \mathrm{C}\end{array}$

cde $28 . \mathrm{P} 8$

$\begin{array}{lllrr}x \text { ben } 4 . C 10 & 3 & 3 & 11 & D \\ x \text { ben 4.D3 } & 0 & 0 & 4 & D / C \\ x \text { ben } 4 . D 19(I) & 1 & 0 & 4 & \text { D/C }\end{array}$

wee 1.6

$\begin{array}{lllll}\text { ben4.D19(I) } & 0 & 0 & 2 & D\end{array}$

(1) Notes: N.D. - no double mutant ( $\left.\underline{\mathrm{cs}}^{-} / \mathrm{ts}^{-}\right)$progeny recovered.

Tetrad classes inferred from surviving progeny (see text).

D - double mutant progeny recovered. These double mutants did not exhibit a "curly" phenotype at $35^{\circ} \mathrm{C}$.

D/C - double mutant progeny recovered. These double mutants exhibited a "curly" phenotype at $35^{\circ} \mathrm{C}$. 
4.11c Linkage testing to nda mutants and $\mathrm{KM}$ strains

Toda and his colleagues (1983) have isolated mutations in twelve loci which confer a cold sensitive mitotic defect. Three of these loci, designated nda (nuclear division arrest) 1,2 and 3 have been genetically well characterised; whereas the representative mutant strains (designated $K M$ ) of the remaining nine loci have been less well studied. The three nda loci were all mapped onto chromosome II, and nda 3 was subsequently found to be allelic to ben 1 (Umesono et al., 1983a).

Mutations in nda2 and nda 3 have been isolated which confer, in addition to a mitotic defect at $22^{\circ} \mathrm{C}$, an altered sensitivity to several benzimidazole carbamate drugs at the permissive temperature $\left(27^{\circ} \mathrm{C}\right)$. On the basis of these pleiotropic phenotypes nda 2 and nda 3 were considered by Umesono et al. (1983a) to be intimately concerned with microtubule organisation and function in $\underline{s}$. pombe. This hypothesis has recently been confirmed with the finding that nda2 and nda 3 are the structural genes for an $\alpha-$ and $\beta-$ tubulin protein respectively (Toda et al., 1984). In the first part of this section the genetical analysis of crosses between some ben 4 mutants and representative alleles of nda2 (KM52) and nda3 (KM311 and ben 1 (nda3) TB1005) is described. The second part of this section describes the genetical analysis of crosses between ben 4 mutants and several of the remaining $K M$ mutant strains.

Immediately after shift to the restrictive temperature $\left(22^{\circ} \mathrm{C}\right)$ nda2.KM52 cells arrest in mitosis with a single compact nucleus. This nucleus is often found to be displaced towards one end of the cell (Toda et al., 1983). With prolonged incubation at $22^{\circ} \mathrm{C}$ the majority of these nuclei divide and commence separation. However, only partial segregation of the nuclear material takes place resulting 
in a population of cells which contain two displaced but closely opposed regions of chromatin. A normally located cell plate forms (either before or after division of the nucleus) in many of these cells, thereby producing an anucleate compartment within the cell (Toda et al., 1983). Mutant nda2.KM52 also shows supersensitivity to the antimicrotubule agents $\mathrm{MBC}, \mathrm{TBZ}$, nocodazole and ethyl N-phenyl carbamate at the permissive temperature (Umesono et al., 1983a). In addition, the presence of the nda2.KM52 mutation was found to suppress the thiabendazole resistance phenotype of mutants ben 1,2 and 3 (Umesono et al., 1983a).

Analysis of the crosses ben $4 . D 3 \times$ nda2.KM52 and ben $4 . C 10 \times$ nda2. KM52 showed that ben 4 and nda2 were not closely linked (Table 4.12). The double mutant ben $4 . C 10$ nda2.KM52 and ben $4 . D 3$ nda2.KM52 were of interest: in both cases, the nda2.KM52 mutation was found to partially suppress the benomyl resistant phenotype conferred by either ben 4 allele. Consequently, both of these double mutants were found to exhibit a level of benomyl resistance intermediate between that of the respective ben 4 parent and the wild type strain. When incubated at $22^{\circ} \mathrm{C}$, both of these ben 4 nda2 double mutants exhibited a similar cold sensitive cdc phenotype: the cells became markedly elongated but also showed slight bending, it was noted that nda2. KM52 cells exhibited this latter characteristic following prolonged incubation at the restrictive temperature (see Figure $5 \mathrm{e}$ in Toda et al., 1981). Mutant nda3.KM311 has been shown to exhibit a cold sensitive mitotic arrest phenotype when incubated at the restrictive temperature $\left(22^{\circ} \mathrm{C}\right)$. Following prolonged incubation at $22^{\circ} \mathrm{C}$, this mutant attains a variety of aberrant cell morphologies which include branched, bent and swollen forms (Umesono et al., 1983a). Since Umesono et al (1983a) have detected allelism between nda 3 and ben 1 , close linkage of ben 4 
with nda3 was not expected (refer also to data in Table 4.9). Indeed, analysis of the cross ben4.D3 $x$ nda3.KM3Il again showed that free recombination occurred between these two loci (Table 4.12). The double mutant ben 4.D3 nda3.KM3Il was resistant to $30 \mu \mathrm{g} / \mathrm{ml}$ of benomyl at $35^{\circ} \mathrm{C}$. When incubated on benomyl free media at $20^{\circ} \mathrm{C}$, this double mutant exhibited a cdc phenotype intermediate between that of either parent: the cells became markedly elongated and also showed slight lateral branching.

The mutant benl (nda3) TB1005 has been shown to exhibit a complex phenotype which consists of four main properties (Umesono et al., 1983a):(1) a cold sensitive cdc phenotype similar to that exhibited by nda3.KM311; (2) strong cross resistance towards MBC and TBZ (a property characteristic of other benl mutants);

(3) a TBZ dependency for optimal growth at the permissive temperature $\left(37^{\circ} \mathrm{C}\right)$; and (4) a spore germination defect at $37^{\circ} \mathrm{C}$ in the absence of TBZ. I found that benl TB1005 grew poorly, but nevertheless formed small colonies on YEA agar at $35^{\circ} \mathrm{C}$. Crosses were made between benI TB1005 and the ben 4 alleles D3 and C10. In each of these crosses only two viable progeny per tetrad were recovered. When tested, the viable progeny fell into one of two phenotypic classes. One class was phenotypically indistinguishable from the wild type strain, whereas the second class was phenotypically indistinguishable from the respective ben 4 single mutant. From this it was clear that the two inviable progeny per tetrad each carried a benl TB1005 allele. A tentative assignment of tetrad classes in this cross was made by reference to the viable progeny of each tetrad (Table 4.12). The observations that (a) progeny carrying a benl TBl005 allele were not obtained in this cross, and (b) wild type and ben4.D3 progeny appeared with equal frequency, provided further evidence that ben 4 and 
Table 4.12 Analysis of crosses between the ben 4 alleles D3 and C10 and some nda mutants and $\mathrm{KM}$ strains.

PD NPD TT

Cross

nda 2. KM52

$\begin{array}{lllr}x \text { ben } 4 . C 10 & 2 & 6 & 12 \\ x \text { ben } 4 . D 3 & 2 & 6 & 8\end{array}$

nda $3 . \mathrm{KM} 311$

$x$ ben $4 . D 3$

$1 \quad 1 \quad 3$

nda 3 (ben 1) TB 1005

$x$ ben $4 . C 10$

$\begin{array}{lll}2 & 3 & 12\end{array}$

$x$ ben $4 . D 3$

3

14

$\mathrm{KM} 48$

$x$ ben $4 . C 10$

4

2

9

KM 108

$x$ ben $4 . C 10$

0

0

3

KM 465

$x$ ben $4 . C 10$

11

$0 \quad 6$

KM 4

$x$ ben $4 . C 10$

Frequency of wild type recombinants $\equiv 18.3 \%$ (see text). 
ben 1 were not closely linked. One possibility, not tested here, was that the spore germination defect conferred by the ben 1 TB1005 allele might have been overcome by the addition of $\mathrm{TBZ}(50 \mu \mathrm{g} / \mathrm{ml})$ to the YEA dissection plates, as described by Umesono et al (1983a). However, the results presented in section $4.11 \mathrm{a}$ suggested that the addition of TBZ in this way might well have inhibited the outgrowth of ben4.D3 ben 1 . ТВ1005 progeny.

The remaining KM strains described by Toda et al. (1983) also exhibit a cold sensitive mitotic defect, following incubation at the restrictive temperature $\left(22^{\circ} \mathrm{C}\right)$. At the time these strains were obtained from the Japanese group, results from haploidization experiments (section 4.13) established that the ben 4 locus was located on chromosome I. With this in mind, attention was focussed on the following KM loci assigned by Toda and coworkers (1983) to chromosome I: $\mathrm{KM} 4,48,108,465,476$ and 525. In my hands, the cold sensitive phenotype expressed by mutants KM476 and 525 was found to be too weak to be of value in genetical analyses. Crosses between ben 4.010 and the remaining chromosome I linked KM mutants (4, 48, 108 and 465) were analysed by either tetrad or random spore analysis. No allelism was detected between ben 4 and any of the KM loci tested (Table 4.12). However, tetrad class data from the cross ben $4 . C 10 \times \mathrm{KM} 465$ (11:0:6, PD:NPD:TT) was suggestive of loose linkage between these two loci. Due to the low frequency of zygotic asci in the mating mix, the cross ben $4 . C 10 \times \mathrm{KM} 4$ was investigated by random spore analysis. Wild type recombinants were detected at a high frequency from this cross (18.3\% of viable progeny scored), thereby ruling out allelism between these two loci. The double mutants ben $4 . \mathrm{C} 10 \mathrm{KM} 48$ and ben4.C10 KM465 were resistant to $30 \mu \mathrm{g} / \mathrm{ml}$ of benomyl at $35^{\circ} \mathrm{C}$ and, in both cases, exhibited a cdc phenotype at $20^{\circ} \mathrm{C}$ more extreme than either of the parental 
mutants: the cells of both double mutants became markedly elongated under these conditions.

\subsection{Dominance relationships}

The dominance relationships of three ben 4 mutant alleles for the benomyl resistance and cold sensitivity phenotypes was investigated in diploid strains. The construction of stable prototrophic diploids, and the method used for their phenotypic characterisation is described in section $2.3 \mathrm{f}$.

The phenotypic characterisation of diploid strains was complicated by the observation that the wild type diploid strain (ben $4^{+} /$ben $4^{+}$) was considerably more sensitive to benomy 1 at $35^{\circ} \mathrm{C}$ than the haploid wild type strain (Table 4.13). Growth of the wild type diploid was completely inhibited, on the basis of bulk growth and the ability to form isolated colonies, by $10 \mu g / m l$ of benomyl (Table 4.13). In contrast, a benomyl concentration of at least $30 \mu \mathrm{g} / \mathrm{ml}$ was required to fully inhibit the growth of the wild type haploid strain (Tables

3.1 and 4.13). Previous studies have shown that certain diploid strains of Aspergillus nidulans (Upshall et al., 1977) and Saccharomyces cerevisiae (Wood and Hartwell, 1982) exhibit increased sensitivity to benomyl and $M B C$ respectively compared to the haploid strain.

A comparison of benomyl resistance was made initially between diploids heterozygous and diploids homozygous for the ben 4 alleles C10, D19(I) and D23(I). The results of these tests are presented in Table 4.13. Diploids homozygous for ben4.D19(I) or ben4.D23(I) were able to form small colonies in the presence of $20 \mu \mathrm{g} / \mathrm{ml}$ of benomyl, with larger colonies appearing on $10 \mu \mathrm{g} / \mathrm{ml}$ of the drug. A very similar pattern of resistance was observed for the corresponding heterozygous diploids ben $4 . D 23(I) /$ ben $4^{+}$and ben $4 . D 19$ (I)/ben $4^{+}$. 
The ben4 alleles D.19(I) and D.23(I) were therefore considered to be dominant to the wild type allele for benomyl resistance. Diploids homozygous for the ben $4 . C 10$ allele were resistant to $20 \mathrm{\mu g} / \mathrm{ml}$ of benomyl. The ben $4.010 /$ ben $4^{+}$heterozygous diploid was, in contrast, completely inhibited by $20 \mu \mathrm{g} / \mathrm{ml}$ of benomyl. The ben $4 . \mathrm{C} 10 /$ ben $4^{+}$ heterozygote was, however, more resistant than the wild type diploid to $10 \mu g / \mathrm{ml}$ of the drug. The ben $4 . C 10$ allele was therefore considered to be semidominant to the wild type allele for benomyl resistance. The dominance relationship of the cold sensitive cdc phenotype exhibited by mutants ben4.D19(I) and ben4.D23(I) was also tested in homozygous and heterozygous diploid strains. The growth of the wild type diploid was similar to that of the wild type haploid strain at either 35 or $20^{\circ} \mathrm{C}$ (Table 4.13). Diploids homozygous for either ben 4.D19(I) or ben4.D23(I) exhibited a pronounced cdc phenotype at $20^{\circ} \mathrm{C}$ but grew normally at $35^{\circ} \mathrm{C}$. Following shift to $20^{\circ} \mathrm{C}$ cells of these mutant diploids became extremely elongated and were unable to form colonies (Table 4.13). The ben4.D19(I)/ben $4^{+}$and ben $4 . D 23(I) /$ ben $4^{+}$diploids expressed a cold sensitive cdc phenotype intermediate between that of the respective homozygous mutants and the wild type diploid.

Mutant ben 4 .C10 exhibited a less pronounced cold sensitive cdc phenotype than either ben4.D19(I) or D23(I). In view of this, testing of the dominance relationship for the cold sensitivity phenotype conferred by the ben $4 . C 10$ allele was less clearcut. Nevertheless, on the basis of cell elongation and colony formation, diploids heterozygous for the ben 4.010 allele were found to exhibit an intermediate level of cold sensitivity compared to the wild type diploid and the ben4.C10 mutant homozygote. All three ben 4 alleles tested (C10, $D 19(I), D 23(I))$ were therefore considered to be semi-dominant to the 
Table 4.13 Dominance relationships of the benomyl resistance and cold sensitivity phenotypes of ben 4 alleles

\begin{tabular}{|c|c|c|c|c|c|c|c|}
\hline & \multirow{2}{*}{$\begin{array}{l}\text { EMM } 35^{\circ} \mathrm{C}^{1} \\
\text { Bulk } \\
\text { growth }\end{array}$} & \multicolumn{2}{|c|}{$\begin{array}{c}\mathrm{EMM}+\mathrm{b} \\
10 \mu \mathrm{g} / \mathrm{ml}\end{array}$} & \multicolumn{2}{|c|}{ b e n $\circ$ m y 1} & \multicolumn{2}{|c|}{ EMM $20^{\circ} \mathrm{C}^{1}$} \\
\hline & & $\begin{array}{l}\text { Bulk } \\
\text { growth }\end{array}$ & $\begin{array}{l}\text { Colony } \\
\text { size }\end{array}$ & $\begin{array}{l}\text { Bulk } \\
\text { growth }\end{array}$ & $\begin{array}{l}\text { Colony } \\
\text { size }\end{array}$ & $\begin{array}{l}\text { Bulk } \\
\text { growth }\end{array}$ & $\begin{array}{c}\text { Colony } \\
\text { size }\end{array}$ \\
\hline ben $4^{+}$ & +++ & +++ & $0.1 \mathrm{~mm}$ & + & 0 & +++ & $1.0 \mathrm{~mm}$ \\
\hline ben $4^{+} /$ben $4^{+}$ & +++ & 0 & 0 & 0 & 0 & +++ & $1.0 \mathrm{~mm}$ \\
\hline ben $4 . D 23(I) /$ ben $4 . D 23(I)$ & +++ & ++ & $1.0 \mathrm{~mm}$ & + & $0.1 \mathrm{~mm}$ & 0 & 0 \\
\hline ben4.D19(I)/ben4.D19(I) & +++ & ++ & $1.0 \mathrm{~mm}$ & + & $0.1 \mathrm{~mm}$ & 0 & 0 \\
\hline ben $4 . D 23(I) /$ ben $4^{+}$ & +++ & ++ & $1.0 \mathrm{~mm}$ & + & $0.1 \mathrm{~mm}$ & + & $0.1 \mathrm{~mm}$ \\
\hline 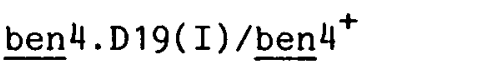 & +++ & ++ & $1.0 \mathrm{~mm}$ & + & $0.1 \mathrm{~mm}$ & + & $0.1 \mathrm{~mm}$ \\
\hline ben $4 . C 10 /$ ben $4 . C 10$ & $++t$ & ++ & $1.5 \mathrm{~mm}$ & ++ & $0.5 \mathrm{~mm}$ & $+/++$ & $0.1 \mathrm{~mm}$ \\
\hline ben $4 . C 10 /$ ben $4^{+}$ & ++ & $+/++$ & $1.0 \mathrm{~mm}$ & 0 & $0.1 \mathrm{~mm}$ & ++ & $0.1 \mathrm{~mm}$ \\
\hline ben 4.D23(I)/ben4.D19(I) & +++ & + & $0.2 \mathrm{~mm}$ & + & $0.1 \mathrm{~mm}$ & 0 & 0 \\
\hline ben $4 . C 10 /$ ben $4 . D 19(I)$ & +++ & ++ & $1.5 \mathrm{~mm}$ & $+/++$ & $0.1 \mathrm{~mm}$ & + & $0.1 \mathrm{~mm}$ \\
\hline ben $4 . C 10 /$ ben $4 . D 23(I)$ & $++t$ & ++ & $1.5 \mathrm{~mm}$ & $+/++$ & $0.1 \mathrm{~mm}$ & + & $0.1 \mathrm{~mm}$ \\
\hline
\end{tabular}

(1) EMM : Bulk growth on EMM agar following four days incubation at the temperature indicated.

Growth scored in relation to growth of the wild type haploid strain under the same conditions (+++ maximal; 0 zero growth); Colony size - approximate diameter of isolated colonies.

(2) EMM + benomyl : Growth on EMM agar containing concentration of benomyl indicated. Growth scored as for (1) above, following three days incubation at $35^{\circ} \mathrm{C}$. 
wild type allele for cold sensitivity.

In an extension of this analysis, mutant diploids heteroallelic for various combinations of the ben4 alleles $\mathrm{C} 10, \mathrm{D} 19$ (I) and D23(I) were constructed and their mutant phenotypes analysed in relation to the diploids described above. The following heteroallelic diploids were analysed: ben4.C10/ben4.D23(I); ben4.C10/ben4.D19(I) and ben4. $\mathrm{D} 19(\mathrm{I}) /$ ben4.D23(I). The heteroallelic diploid containing the two alleles which conferred a strong cold sensitive phenotype (ben4.D23(I)/ ben4.D19(I)) exhibited a cold sensitive cdc phenotype similar to that of the ben4.D19(I) and ben4.D23(I) homozygous diploids. Rather surprisingly, the level of benomyl resistance of the ben4.D19(I)/ ben4.D23(I) diploid was found to be intermediate between that of the wild type diploid and the D19(I) and D23(I) homozygous mutant diploids (Table 4.13). This result indicated a degree of interaction between ben4.D19(I) and ben4.D23(I); this in turn suggested that these two ben4 alleles may not be identical.

Heteroallelic diploids of the composition ben4.C10/ben4.D23(I) and ben $4.010 /$ ben4.D19(I) exhibited a level of benomyl resistance and cold sensitivity intermediate between that shown by the ben 4 . C10 and the ben4.D19(I) and ben4.D23(I) homozygous diploids (Table 4.13).

\subsection{Chromosome allocation of the ben4 locus}

The m-fluorophenylalanine (m-FPA) induced haploidization procedure described by Kohli et al. (1977) was used to assign the ben4 locus to one of the three chromosomes present in the haploid genome of $\underline{s}$. pombe (Kohli et al., 1977; Umesono et al., 1983b; Robinow, 1977). Stable non-sporulating diploids heterozygous for the ben4.D3 locus were constructed as described in section $2.3 \mathrm{~g}$. Three independent diploid clones were selected and each one was then treated with m-FPA to induce 
haploidization. At least one hundred haploid segregants from each m-FPA treated diploid were selected for phenotypic characterisation. Haploid segregants were scored for the presence of each of the genetic markers carried by the parental diploid. The mat2.102 marker proved difficult to score and this data was not included in the subsequent analysis.

The genetic constitution of each of the haploid segregants was compiled separately for each independent experiment, this data allowed the segregation pattern of the ben 4 marker with each auxotropic marker to be examined in turn. The segregation pattern of markers in each of the gene pairs ben4-lysl (chromosome I); ben4-ural (chromosome I); ben4-leu1 (chromosome II) and ben4-ade6 (chromosome III) was tabulated for each experiment (Table 4.14). For each gene pair, a significant excess of parental combinations with a concomitantly low frequency of recombinant types within the table indicated a departure from independent assortment and was therefore equated with linkage. This situation was clearly observed for the gene pairs ben4-ural and ben4-1ys1 (Table 4.14). These data strongly indicated that ben 4 is located on chromososme I. Analysis of the gene pairs ben4-leul and ben4-ade6 showed that parental and recombinant types appeared at high frequency (Table 4.14). This result ruled out linkage of ben4 to either chromosome II or chromosome III. In the ben4-1eu1 gene pair a consistent deficiency in the frequency of the ben ${ }^{r} \underline{e u}^{-}$parental type (Table 4.14) was observed. The reason for the selective loss of segregants carrying this genetic combination is unclear. In one instance (experiment 3; Table 4.14), the frequency of ben ${ }^{s} \underline{\text { lys }}^{+}$recombinants was relatively high, although no ben ${ }^{\mathrm{r}}$ lys $^{-}$recombinants. were observed. The increased level of bens lys $^{+}$recombinants in this case is consistent with a single mitotic crossover event occurring in the diploid prior to 
Table 4.14 Chromosome allocation of ben4.

\section{Experiment 1}
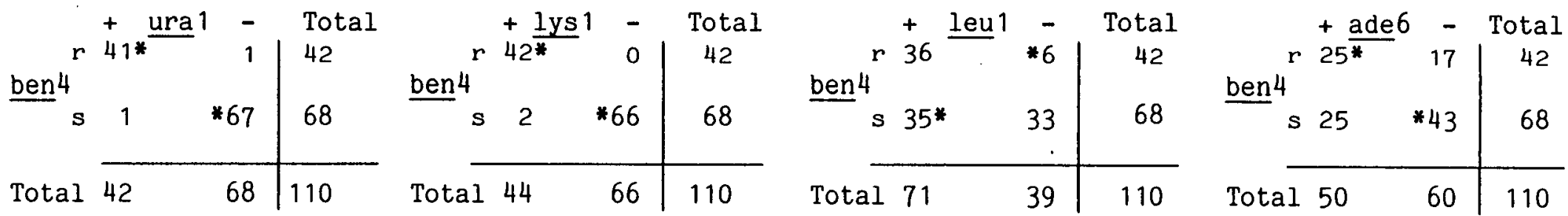

Experiment 2
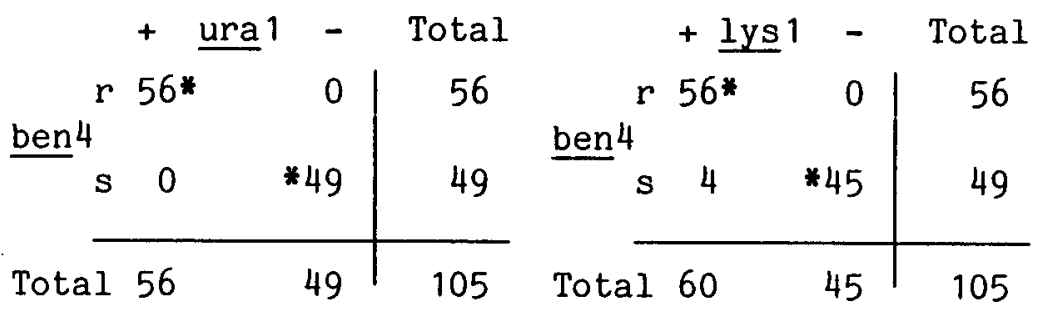

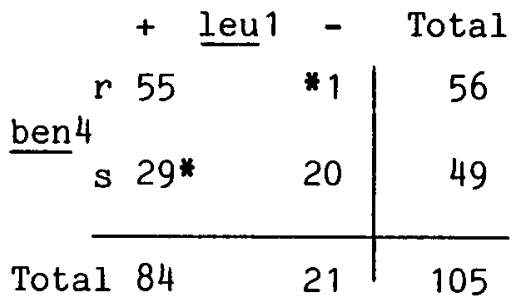

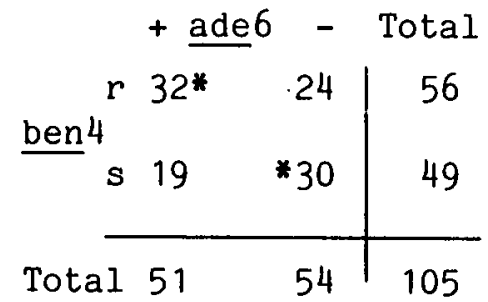

\section{Experiment 3}

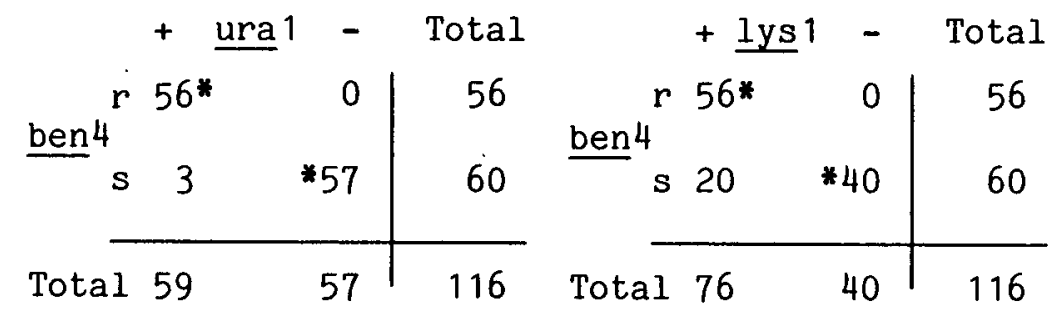

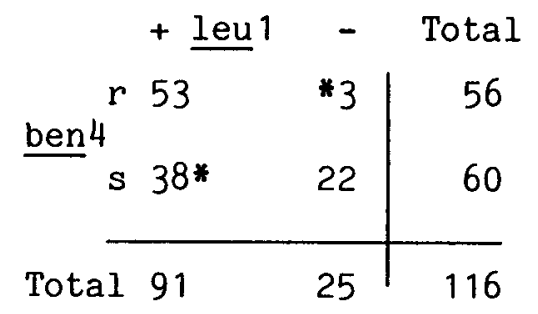

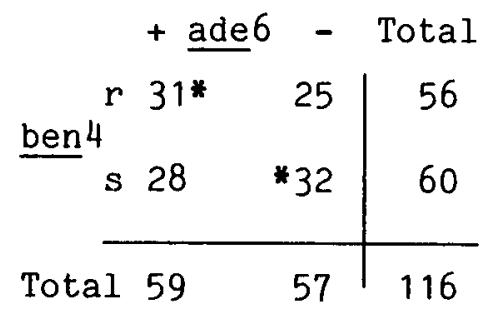

Notes: + and - indicate presence of either the wild type or the mutant allele respectively; $r$ (resistant) and s(sensitive) indicate presence of mutant or wild type allele respectively. Entries marked (*) represent parental combinations. 
haploidization. The lys 1 locus is situated close to the centromere on the left arm of chromosome I, whereas the ural locus is located distally to the centromere on the right arm of the same chromosome (Gygax and Thuriaux, 1984). In view of this, the low frequency of ben ${ }^{r}$ ura $^{-}$and $\underline{\text { ben }}^{s}$ ura $^{+}$recombinants observed in experiment 3 places a constraint on the location of the proposed crossover event. The crossover would

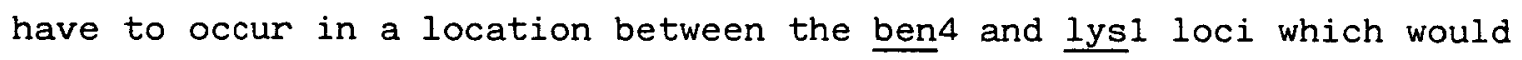
not disrupt the original ben4-ural relationship. Since mitotic crossing over involves a reciprocal exchange between non-sister chromatids, the frequency of the ben ${ }^{r} \underline{y s}^{-}$recombinants would also be expected to be relatively high in this instance. In fact, no ben ${ }^{r} \underline{y s}^{-}$recombinants were observed (Table 4.14). This situation may be due to the occurrence of either non-disjunction or selective loss of $\underline{b e n}^{r} \underline{\text { lys }}^{-}$recombinants in the diploid following the proposed crossover event.

The model proposed above locates the ben4 locus to the right arm of chromosome I. However, the position of the ben4 locus relative to the ural locus cannot be deduced from the available data.

\subsection{Further analysis of benomyl resistant mutants}

The selection procedure outlined in Figure 1.2 was found to strongly enrich for mutants with a benomyl resistant cold sensitive cdc phenotype (Chapter 3 ). The genetical analysis presented in this chapter showed that this isolation scheme offered a stringent selection for mutations in the ben 4 locus. The possibility remained, nonetheless, that a proportion of the benomyl resistant mutants (whether cold sensitive or not) obtained might map to loci other than ben4. Other questions concerned the spectrum of phenotypes conferred by mutations at the ben 4 locus. For instance, can ben 4 mutations which confer 
resistance to benomyl but which do not in turn confer a cold-sensitive cdc phenotype be selected? Another question asks whether it is possible to obtain ben 4 mutants which exhibit both resistance to benomyl and a heat sensitive $\underline{c d c}$ phenotype. This section describes the isolation and genetical analysis of additional benomyl resistant mutants in an attempt to address such questions.

4.14a Isolation of additional benomyl resistant mutants

Three independent isolations of mutants resistant to $30 \mu \mathrm{g} / \mathrm{ml}$ of benomyl at $35^{\circ} \mathrm{C}$ were carried out as previously described in section 3.2. The benomyl resistant mutants obtained from each isolation were grouped into four phenotypic classes with respect to bulk growth and cellular morphology at $20^{\circ} \mathrm{C}$. The overall range of mutant phenotypes exhibited by these new isolates (Table 4.15) was similar to that obtained in the original selection (Table 3.2). However, the frequency of mutants within each phenotypic class was variable between the different isolations.

Nine of the newly isolated benomyl resistant mutants were selected for further study (Table 4.16). Six of these grew normally at $20^{\circ} \mathrm{C}$ and were considered analogous to the Class $\mathrm{Y}$ mutants obtained in the original isolation (Table 3.2 ). The remaining three mutants exhibited a cold sensitive cdc phenotype at $20^{\circ} \mathrm{C}$ and were phenotypically indistinguishable from the Class $X$ mutants described previously (Table 3.2). All nine mutants were backcrossed to the wild type strain and a number of asci from each cross were dissected and analysed (Table 4.16). Tetrads analysed from backcrosses involving each of the benomyl resistant mutants which grew normally at $20^{\circ} \mathrm{C}$ gave a regular $2: 2$ (mutant: wild type) segregation pattern for benomyl resistance (Table 4.16). Therefore, in each of these mutants, benomyl resistance was conferred by a mutation in a single nuclear gene. Backcrosses involving each of the 
Table 4.15 Phenotypic characterisation of benomyl resistant mutants recovered from three independent isolations.

Isolation

$$
\mathrm{R} /+++{ }^{1} \mathrm{R} /+^{2} \quad \mathrm{R} /+^{3} \quad \mathrm{R} / \mathrm{O}^{4} \cdot \text { Total }
$$

$\begin{array}{lrrrrr}\text { I } & 41 & 24 & 5 & 0 & 70 \\ \text { II } & 33 & 9 & 39 & 5 & 86 \\ \text { III } \quad . \quad 86 & 53 & 24 & 15 & 178\end{array}$

$(1-4) \mathrm{R}$ - resistant to $30 \mu \mathrm{g} / \mathrm{ml}$ of benomyl at $35^{\circ} \mathrm{C}$.

(1). /+++ growth and morphology at $20^{\circ} \mathrm{C}$ indistinguishable from that of the wild type strain (analogous to Class $Z$ mutants in Table 3.2).

(2) /++ poor bulk growth at $20^{\circ} \mathrm{C}$, cells exhibit slightly elongated phenotype (analogous to Class $Y$ mutants in Table 3.2 ).

(3) I+ very poor bulk growth at $20^{\circ} \mathrm{C}$, cells exhibit elongated cylindrical morphology (analogous to Class $\mathrm{Z}$ mutants in Table 3.2).

(4) 10 zero bulk growth at $20^{\circ} \mathrm{C}$, cell morphology not elongated. 
Table 4.16 Genetical analysis of additional benomyl resistant mutants

\begin{tabular}{|c|c|c|c|c|c|c|c|}
\hline \multirow{2}{*}{$\begin{array}{l}\text { Strain } \\
\text { isolation } \\
\text { number }\end{array}$} & \multirow{2}{*}{ Phenotype 2} & \multicolumn{3}{|c|}{$\begin{array}{l}\text { Cross } \\
\times 975 h^{+}\left(\underline{\text { ben }}^{\mathrm{s}} \mathrm{cs}^{+}\right)\end{array}$} & \multicolumn{3}{|c|}{$\begin{array}{l}\text { Cross } \\
\times \text { ben } 4 . C 10\end{array}$} \\
\hline & & $\begin{array}{l}\text { Number of } \\
\text { asci } \\
\text { dissected }\end{array}$ & $\begin{array}{l}\text { Composition } \\
\text { of tetrad }\end{array}$ & $\begin{array}{l}\text { Number } \\
\text { observed }\end{array}$ & $\mathrm{PD}$ & NPD & $\mathrm{TT}$ \\
\hline I. 2 & $\underline{\text { ben }}^{r} \underline{c s}^{+}$ & 8 & $2 \underline{b e n}^{r} \underline{c s}^{+}: 2 \underline{b e n}^{s}{ }^{c s^{+}}$ & 8 & 1 & 4 & 3 \\
\hline I. 3 & $\underline{\text { ben }}^{r} \underline{c s}^{+}$ & 9 & $2 \underline{\text { ben }}^{r} \underline{\operatorname{cs}}^{+}: 2 \underline{b e n}^{s} \underline{c s}^{+}$ & 9 & 0 & 3 & 6 \\
\hline IIIA 1 & $\underline{\text { ben }}^{r} \underline{c s}^{+}$ & 8 & $2 \underline{b e n}^{r} \underline{c s}^{+}: 2$ ben $^{s} \underline{c s}^{+}$ & 8 & 1 & 1 & 7 \\
\hline IIIA3 & $\underline{\text { ben }}^{r} \underline{c s}^{+}$ & 8 & $2 \underline{b e n}^{r} \underline{c s}^{+}: 2 b^{s e n}{ }^{s}{ }^{c s^{+}}$ & 8 & 2 & 1 & 5 \\
\hline IIID47 & $\underline{\text { ben }}^{r} \underline{c s}^{+}$ & 6 & $2 \underline{b e n}^{r} \underline{c s}^{+}: 2 b^{s e n}{ }^{s}{ }^{+}$ & 6 & 0 & 2 & 5 \\
\hline IIIE61 & $\underline{\text { ben }}^{r} \underline{\mathrm{cs}}^{-}$ & 8 & $2 \underline{b e n}^{r} \underline{c s}^{-}: 2 \underline{b e n}^{s}{ }^{c s^{+}}$ & 8 & 10 & 0 & 0 \\
\hline IIIE62 & $\underline{b e n}^{r} \underline{c s}^{-}$ & 4 & $2 \underline{b e n}^{r}{ }^{c s^{-}}: 2 b e n^{s} \underline{c s}^{+}$ & 4 & 9 & 0 & 0 \\
\hline IIIF73 & $\underline{\text { ben }}^{r} \underline{c s}^{-}$ & 10 & $2 \underline{b e n}^{r} \underline{c s}^{-}: 2 \underline{b e n}^{s}{ }^{s}{ }^{+}$ & 10 & 9 & 0 & 0 \\
\hline IIIF74 & $\underline{\text { ben }}^{r} \underline{c s}^{+}$ & 8 & 2 ben $^{r}{ }^{\operatorname{cs}^{+}}: 2$ ben $^{s} \underline{c s}^{+}$ & 9 & 3 & 0 & 7 \\
\hline
\end{tabular}

(1) Strain designation : numerals $I_{0}$ II or III refer to isolation origin (see Table 4.15); letter and number refer to clonal origin of the strain.

(2) Phenotype: $\underline{\text { ben }}^{r}$ - resistant to $30 \mu g / m l$ of benomyl at $35^{\circ} \mathrm{C}$.

$\underline{\text { ben }}^{\mathrm{S}}$ - wild type sensitivity to $30 \mu \mathrm{g} / \mathrm{ml}$ of benomyl at $35^{\circ} \mathrm{C}$.

$\underline{\mathrm{es}}^{+}$- wild type growth and division at $20^{\circ} \mathrm{C}$.

$\underline{\mathrm{cS}}^{-}$- cold sensitive $\underline{\mathrm{cdc}}$ phenotype following three days incubation at $20^{\circ} \mathrm{C}$. 
three benomyl resistant cold sensitive mutants gave tetrads which exhibited regular co-segregation of benomyl resistance with cold sensitivity in a 2:2 mutant:wild type fashion (Table 4.16). This segregation pattern established that, in each case, the dual mutant phenotype was the result of a single nuclear gene mutation.

Each one of the nine newly isolated mutants was then crossed in turn to mutant ben4.C10. The tetrad class data presented in Table 4.16 shows that the three benomyl resistant cold sensitive mutants, III 61, III 62 and III F73, were allelic to ben4. Of particular interest was that none of the six benomyl resistant mutants which exhibited normal growth at $20^{\circ} \mathrm{C}$ were allelic to ben 4.

Although this analysis was performed on a relatively small sample of mutants, it is clear that the selection of benomyl resistant cold sensitive mutants using this approach offers strong selection for mutations at the ben 4 locus. In contrast, benomyl resistant mutants which do not exhibit a cold sensitive cdc phenotype map to loci other than ben 4 .

4.14b Isolation of benomyl resistant heat sensitive cde mutants

It was considered that the range of mutant phenotypes conferred by lesions at the ben 4 locus might be extended through the isolation of benomyl resistant mutants which exhibit a heat sensitive (hs) cdc phenotype. Essentially the reverse selection procedure to that described in Figure 1.2 was employed to isolate mutants of this sort. That is, selection for benomyl resistance was carried out at $20^{\circ} \mathrm{C}$, using $35^{\circ} \mathrm{C}$ as the restrictive temperature at which to screen resistant mutants for a heat sensitive cdc phenotype. Due to the increased sensitivity of the wild type strain to benomyl at lower temperatures (Table 3.1 ), the selection of resistant mutants at $20^{\circ} \mathrm{C}$ was carried out with a lower concentration of benomyl than that used in the 
original isolation. Wild type cells were spread onto EMM agar containing either 5 or $10 \mu \mathrm{g} / \mathrm{ml}$ of benomyl and the plates were then irradiated with U.V. as described previously (section 2.3b). The mutagenised plates were incubated at $20^{\circ} \mathrm{C}$ for six days to select for drug resistant isolates. A total of 717 benomyl resistant mutants were picked from the drug-containing plates after this time. Resistant mutants appeared at a higher frequency on plates containing $5 \mu \mathrm{g} / \mathrm{ml}$ of benomyl ( 532 mutants) than on plates supplemented with $10 \mu \mathrm{g} / \mathrm{ml}$ of the drug ( 185 mutants). No resistant mutants were seen on the control (non-irradiated) plate containing $10 \mu g / m l$ of benomyl, whereas two spontaneously resistant mutants appeared on the $5 \mu \mathrm{g} / \mathrm{ml}$ control plate. All 719 resistant mutants were picked onto EMM agar. After two days incubation at $20^{\circ} \mathrm{C}$ replicates were made onto EMM agar containing magdala red, and the replicates were then incubated overnight at $35^{\circ} \mathrm{C}$. After this, progeny with an hs phenotype were identified on the basis of poor bulk growth and intense magdala red staining. Nine benomyl resistant hs isolates were identified in this way. Microscopical examination revealed that only two of these exhibited a cdc phenotype at $35^{\circ} \mathrm{C}$. These isolates were designated $\underline{\mathrm{hs}} \mathrm{R} 5$ and $\underline{\mathrm{hs}} \mathrm{R} 10$ to reflect the original selection of these strains at $20^{\circ} \mathrm{C}$ on 5 and $10 \mu \mathrm{g} / \mathrm{ml}$ of benomyl respectively. Strain hsR10 exhibited only partial cellular elongation following overnight incubation at $35^{\circ} \mathrm{C}$. By contrast, hsR5 cells became markedly elongated under these conditions. It was also noted that the majority of hsR5 $^{-}$cells contained a single transverse septum, which divided the cells into two unequal sized compartments. The smaller of the two compartments within each hsR5 cell was found to stain intensely with magdala red. A detailed account of the physiological and cytological properties of $\mathrm{hsR}^{-}$cells is presented in sections $5.4 \mathrm{c}$ and 6.8 respectively. 
That the dual mutant phenotype exhibited by hsR5 and hsR10 was conferred, in each case, by a single nuclear gene mutation was demonstrated by tetrad analysis. The progeny in each tetrad examined from backcrosses between these isolates and the wild type strain showed cosegregation of heat sensitivity with benomyl resistance in a $2: 2$ mutant: wild type fashion (Table 4.17). Mutants hsR5 and hsR10 were also crossed to a ben 4 .C10 mutant of opposite mating type. The tetrad class data obtained from these crosses (Table 4.17) established that hs R5 was not closely linked to ben 4 , although there is evidence for loose linkage between ben 4 and hsR10. The ben $4 . C 10$ hsR10 double mutant grew well and formed colonies at 27 and $30^{\circ} \mathrm{C}$. This double mutant exhibited a cde phenotype when tested at either 35 or $20^{\circ} \mathrm{C}$. The double mutant ben $4 . \mathrm{C} 10$ hsR5 grew poorly and formed only small colonies at either 27 or $30^{\circ} \mathrm{C}$; in many instances tetrad class data were obtained from the viable progeny of the tetrad. It was clear, nevertheless, that the double mutant ben 4.010 hsR5 expressed a cdc phenotype at either restrictive temperature.

Subsequent physiological and cytological characterisation (sections $5.4 \mathrm{c}$ and 6.8 ) showed that the terminal phenotype exhibited by hsR cells was similar to the terminal phenotype of the cold sensitive mitotic mutant nda2. KM52 (Umesono et al., 1983a). The possibility of allelism between these two strains was tested by random spore analysis. Since the cross involved heat sensitive and cold sensitive markers, mating and sporulation were carried out at two intermediate temperatures, 25 and $30^{\circ} \mathrm{C}$. Random spores from each cross were prepared and plated onto $\mathrm{YE}$ agar. Plates containing spores derived from the $30^{\circ} \mathrm{C}$ cross were further incubated at $30^{\circ} \mathrm{C}$; likewise, plates containing spores derived from the $25^{\circ} \mathrm{C}$ cross were incubated at $25^{\circ} \mathrm{C}$. Colonies appeared on both sets of plates following several days incubation under these 
Table 4.17 Genetical analysis of benomyl resistant heat sensitive strains hsR5 and hsR10.

\begin{tabular}{|c|c|c|c|c|c|c|c|}
\hline \multirow{2}{*}{ Strain } & \multirow{2}{*}{ Phenotype ${ }^{1}$} & \multicolumn{3}{|c|}{$\begin{array}{l}\text { Cross } \\
\times 975 \underline{h}^{+}\left(\text {ben }^{\text {s }} \underline{h s}^{+}\right)\end{array}$} & \multicolumn{3}{|c|}{$\begin{array}{l}\text { Cross } \\
\mathrm{x} \text { ben } 4 . C 10\end{array}$} \\
\hline & & $\begin{array}{l}\text { Number of } \\
\text { asci } \\
\text { dissected }\end{array}$ & $\begin{array}{l}\text { Composition } \\
\text { of tetrad }\end{array}$ & $\begin{array}{l}\text { Number } \\
\text { observed }\end{array}$ & PD & NPD & TT \\
\hline hs $R 5$ & $\underline{b e n}^{\mathrm{r}} \underline{\mathrm{hs}}^{-}$ & 19 & $2 \underline{b e n}^{r} \underline{h s}^{-}: 2 \underline{b e n}^{s} \underline{h s}^{+}$ & 19 & 7 & 1 & 11 \\
\hline hsR 10 & $\underline{b e n}^{r} \underline{h s}^{-}$ & 11 & $2 \mathrm{ben}^{\mathrm{r}} \mathrm{hs}^{-}: 2 \mathrm{ben}^{\mathrm{s}} \mathrm{hs}^{+}$ & 11 & 9 & 0 & 3 \\
\hline
\end{tabular}

(1) Phenotype ben ${ }^{r}$ - resistant to $30 \mu \mathrm{g} / \mathrm{ml}$ of benomyl at $35^{\circ} \mathrm{C}$.

$\underline{\text { ben }}^{\mathrm{S}}$ - wild type sensitivity to $30 \mu \mathrm{g} / \mathrm{ml}$ of benomyl at $35^{\circ} \mathrm{C}$.

$\underline{\mathrm{hs}}^{+}$- wild type growth and division at $35^{\circ} \mathrm{C}$.

$\underline{\text { hs }}^{-}$- heat sensitive $\underline{\mathrm{cdc}}$ phenotype at $35^{\circ} \mathrm{C}$. 
Table 4.18 Genetical analysis of the cross nda2.KM52 $x$ hsR5

\begin{tabular}{l|cccc}
$\begin{array}{l}\text { Temperature } \\
\text { at which cross } \\
\text { was performed }\end{array}$ & $\begin{array}{c}\text { Phenotypic characterisation of progeny } \\
\mathrm{hs}^{+} \underline{\mathrm{cs}}^{+}\end{array}$ & $\underline{\mathrm{hs}^{+}} \underline{\mathrm{cs}}^{-}$ & $\underline{\mathrm{hs}^{-}} \underline{\mathrm{cs}}^{+}$ & $\underline{\mathrm{hs}^{-}} \underline{\mathrm{cs}}^{-}$ \\
\hline $25^{\circ} \mathrm{C}$ & 52 & 0 & 98 & 0 \\
$30^{\circ} \mathrm{C}$ & 58 & 90 & 0 & 0
\end{tabular}

(1) $\underline{\mathrm{hs}}^{+}-$good bulk growth at $35^{\circ} \mathrm{C}$

$\mathrm{hs}^{-}$- poor bulk growth at $22^{\circ} \mathrm{C}$

$\underline{\mathrm{cS}}^{+}-$good bulk growth at $35^{\circ} \mathrm{C}$

$\mathrm{CS}^{-}$- poor bulk growth at $22^{\circ} \mathrm{C}$.

Phenotypes of parental strains $\begin{array}{ll}\underline{\text { nda2 2. KM52 }} & \underline{\mathrm{hs}}^{+} \mathrm{cs}^{-} \\ \underline{\mathrm{hs}} & \underline{\mathrm{hs}^{-}} \underline{\mathrm{cs}}^{+}\end{array}$ 
conditions. Separate master plates were prepared on YE agar from the progeny obtained at 30 and $25^{\circ} \mathrm{C}$. The bulk growth of the progeny was scored following two days incubation at these temperatures. The results from the analysis are presented in Table 4.18.

Wild type recombinant progeny (progeny which grew well at both 35 and $22^{\circ} \mathrm{C}$ ) were recovered at high frequency from the crosses carried out at either temperature (Table 4.18 ). This result established that nda2 and hsR5 were not allelic. Only two phenotypic classes of progeny were recovered from the $30^{\circ} \mathrm{C}$ cross. One class represented wild type recombinants ( $\underline{\mathrm{hs}}^{+} \underline{\mathrm{cs}}^{+}$class; Table 4.18), whereas the second class exhibited an $\underline{\mathrm{hs}}^{+} \underline{\mathrm{cs}}^{-}$phenotype. These latter progeny were considered to represent the nda2.KM52 single mutant. Thus, progeny carrying the $\underline{\text { hsR5 }}$ allele were not obtained from crosses carried out at $30^{\circ} \mathrm{C}$. Likewise, only two classes of progeny were recovered from the $25^{\circ} \mathrm{C}$ cross. One class were wild type recombinants, the other a class of hs $^{-}$cs $^{+}$progeny (Table 4.18). This latter class were considered to represent hsR5 progeny. This pattern established that, in crosses carried out at $25^{\circ} \mathrm{C}$, there was strong selection against the appearance of progeny which carried the nda2.KM52 mutation. Consequently, the nda2.KM52 hsR5 double mutant was not recovered from either the 25 or the $30^{\circ} \mathrm{C}$ cross.

The results presented in this latter section, although representing the analysis of just two isolates, indicated that the isolation of benomyl resistant heat sensitive mutants (using the basic approach depicted in Figure 1.2) may not give strong selection for mutation in the ben 4 locus. 


\section{Chapter 5 \\ PHYSIOLOGICAL CHARACTERISATION}

\subsection{Introduction}

The mutants isolated in this study were selected on the basis of a dual phenotype. At the permissive temperature $\left(35^{\circ} \mathrm{C}\right)$ the mutants showed increased resistance to the antimitotic agent benomyl. At $20^{\circ} \mathrm{C}$, the mutants exhibited a cold sensitive defect consistent with a block in cell cycle progress. This chapter examines more closely the physiology of several of these mutant strains. Experimental attention was focussed on two areas. Firstly, an analysis of the physiological response of selected mutants following shift to the restrictive temperature was undertaken. Information from these experiments would allow the nature and timing of the cell cycle block to be determined. Secondly, an analysis was made of the drug resistance spectrum conferred by mutations at the ben 4 locus.

In addition to these studies, a physiological characterisation of the benomyl resistant heat sensitive strains hs $R 5$ and hs $R 10$ (section 4.14 ) was conducted.

5.2 Analysis of the cold sensitive cde phenotype of the benomyl

\section{resistant mutants}

A high proportion of the benomyl resistant mutants isolated in this study expressed an elongated cylindrical morphology at $20^{\circ} \mathrm{C}$, a phenotype characteristic of the continuation of growth during a division block. Following on from this initial observation, experiments were conducted in order to answer two main questions concerning the nature and timing of the $\underline{c s} \underline{c d c}$ defect in these strains. Firstly, after shift to the restrictive temperature, where do the specific 
transition point(s), if any, occur? Secondly, what is the nature of the final (terminal) mutant phenotype? In an attempt to answer such questions, various parameters of cell growth and division were monitore in liquid cultures of selected mutants following shift from the permissive $\left(35^{\circ} \mathrm{C}\right)$ to the restrictive temperature $\left(20^{\circ} \mathrm{C}\right)$. The mutants analysed were: ben 4.D2, D3, and C10, as well as the modifier free strains (Table 4.5) ben4.A22(I), C29(I), D19(I) and D23(I). In addition, the response of the following strains not subject to a detailed genetical examination was also analysed: B18, C23, D12 and E14 (Table 4.4).

\section{$5.2 a$ Growth of strains at the permissive temperature}

During exponential growth in liquid culture at $35^{\circ} \mathrm{C}$, all of the mutant strains tested had longer generation times than the wild type (Table 5.1). The strongly cold sensitive strain $\mathrm{C} 23$ and the ben 4 mutants D2, D3, A22(I), C29(I), D19(I) and D23(I) exhibited the longest generation times, whereas those mutants with a less pronounced cs cdc phenotype (B18, D12 and ben4.C10) had generation times comparable to that of the wild type. The mean cell length of wild type cells in exponential growth at $35^{\circ} \mathrm{C}$ was $9 \mu \mathrm{m}$, and the mean cell length of each of the mutants tested was similar to this value. It was noticeable, however, that cells of those mutants with a strong cold sensitive phenotype (C23 and ben4.D2, D3, A22(I), C29(I), D19(I) and $D 23(I)$ ) exhibited a slight curvature in cell morphology (not shown) at the permissive temperature, in contrast to the uniform short-cylindrical morphology of wild type cells.

From these observations the growth and division of the mutants at the permissive temperature was considered to be broadly similar to that of the wild type. The following section examines the physiological response of the various mutants selected (Table 5.1) to 
temperature shift down, that is, from 35 to $20^{\circ} \mathrm{C}$.

\section{$5.2 b$ Response of strain 972 to temperature shift down}

Wild type cells continued to divide for approximately two hours following shift to $20^{\circ} \mathrm{C}$ (Figure 5.1). A transient plateau in the cell number curve, lasting for approximately one hour, was observed after the initial increase. Cell division resumed at an increased rate after the short plateau period and continued to increase for the remainder of the experiment. Changes in the cellular dry mass of the culture, estimated from turbidity measurements (Mitchison, 1970), were used to monitor cell growth. The turbidity of the wild type culture increased continuously after temperature shift down, and no major fluctuations comparable with those in the cell number curve were seen.

The percentage of binucleated cells (analogous to the mitotic index of higher cells) in the culture fell close to zero immediately after shift down (Figure 5.1), and remained at a low level for about one hour. After this time, a burst of mitosis occurred; the frequency of binucleated cells increased, reaching a peak approximately three hours after shift down. The fraction of binucleated cells then fell sharply to a value slightly less than that observed before the shift: A second but only minor increase in binucleated cells was seen around 7.5 hours post-shift. This secondary increase may represent the establishment of a new steady state level of binucleated cells under these conditions.

A slight and transient decrease in the mean cell length of wild type cells from $8.9 \mu \mathrm{m}$ to $8.5 \mu \mathrm{m}$ occurred immediately after shift down. After this, the mean cell length of the population increased, coincident with the transient plateau period in cell division, to a 


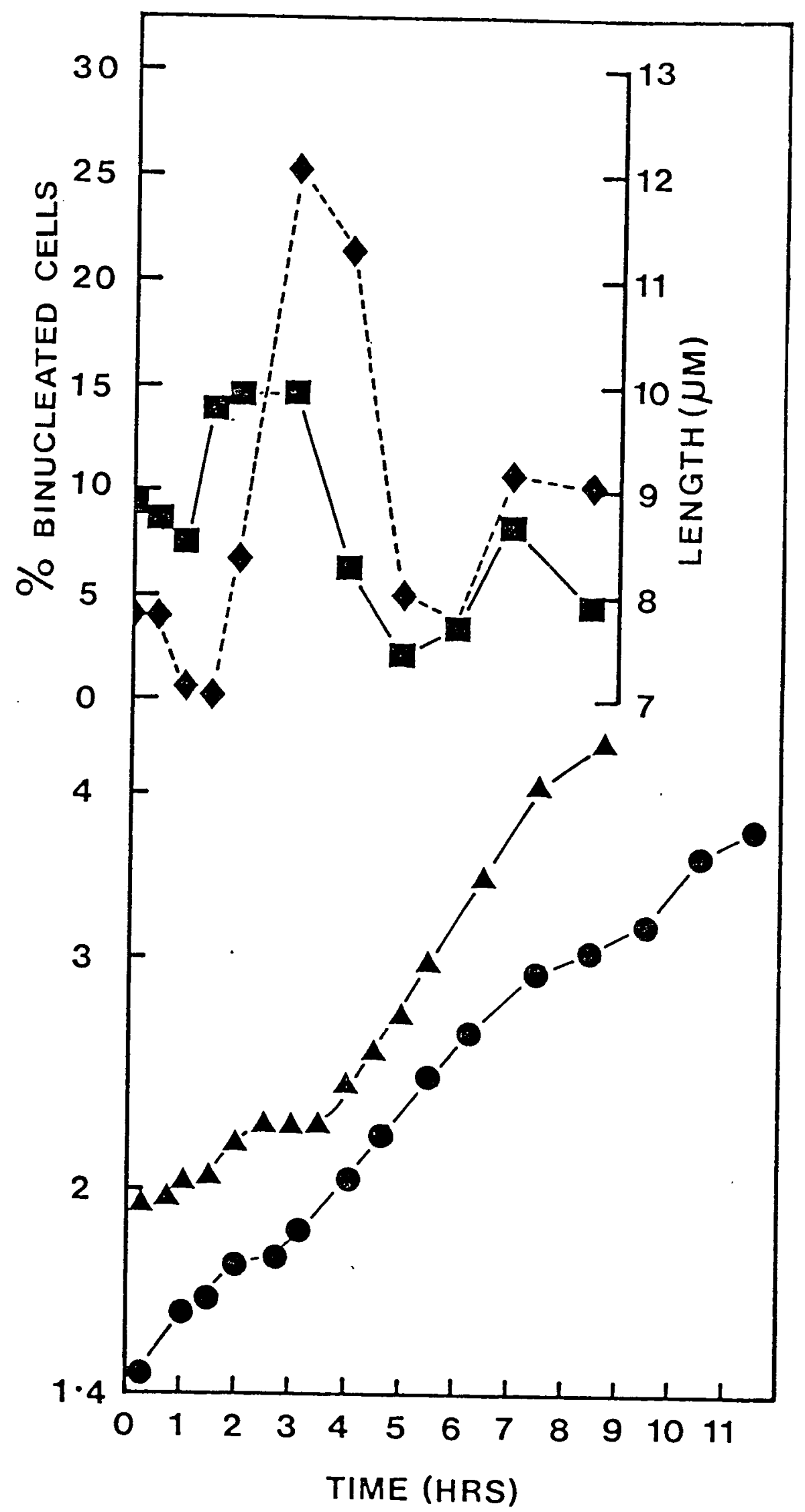

Fig. 5.1 Effect of temperature shift down on strain 972.

At time zero exponentially growing cells of strain 972 were transferred from 35 to $20^{\circ} \mathrm{C}$; samples were taken to determine: cell number/ml (A); frequency of binucleate cells $(\$)$; mean cell length ${ }_{6}(\mathbf{a})$; and turbidity $\left(A_{595 \mathrm{~nm}}\right)(\bullet)$. One unit on arbitrary $l \circ g$ scale $=10 \% \mathrm{cells} / \mathrm{ml}$, and $0.1 \mathrm{~A}_{595 \mathrm{~nm}}$ uni 
Table 5.1 Growth and division of benomyl resistant cold sensitive mutants under permissive $\left(35^{\circ} \mathrm{C}\right)$ and restrictive $\left(20^{\circ} \mathrm{C}\right)$ conditions.

\begin{tabular}{|c|c|c|c|c|c|c|}
\hline \multirow[t]{2}{*}{ Strain } & \multicolumn{2}{|c|}{$\begin{array}{l}\text { Mass (turbidity) } \\
\text { doubling time (hours) }\end{array}$} & \multirow{2}{*}{$\begin{array}{c}\text { Duration of } \\
\text { cell number } \\
\text { plateau at } 20^{\circ} \mathrm{C} \\
\text { hours }\end{array}$} & \multicolumn{2}{|c|}{ Mean cell length $(\mu \mathrm{m})( \pm \text { SEM })^{1}$} & \multirow[t]{2}{*}{$\begin{array}{l}\text { Transition } \\
\text { point }\end{array}$} \\
\hline & $35^{\circ} \mathrm{C}$ & $20^{\circ} \mathrm{C}$ & & $35^{\circ} \mathrm{C}$ & $20^{\circ} \mathrm{C}(12$ hours $)$ & \\
\hline 972 & 2.4 & 8.0 & 1 & $8.9 \pm 0.3$ & $6.5 \pm 0.2$ & - \\
\hline $\mathrm{B} 18$ & 3.3 & 12.0 & 5 & $7.9 \pm 0.5$ & $13.0 \pm 0.8$ & 0.71 \\
\hline $\mathrm{C} 23$ & 3.6 & 12.7 & 7 & $8.6 \pm 0.5$ & $12.4 \pm 0.7$ & 0.70 \\
\hline D 12 & 3.1 & 11.6 & 3 & $7.3 \pm 0.4$ & $10.6 \pm 0.6$ & 0.73 \\
\hline E14 & $3 \cdot 5$ & 13.5 & 8 & $7.7 \pm 0.6$ & $12.4 \pm 0.8$ & 0.76 \\
\hline ben $4 . C 10$ & 3.2 & 10.0 & 3 & $8.1 \pm 0.3$ & $11.2 \pm 0.3$ & 0.79 \\
\hline ben $4 . D 2$ & 3.7 & 13.5 & 7 & $10.1 \pm 0.2$ & $15.5 \pm 0.4$ & 0.86 \\
\hline ben $4 . D 3$ & 3.7 & 14.0 & 6 & $8.9 \pm 0.3$ & $16.4 \pm 0.5$ & 0.78 \\
\hline ben $4 . A 22(I)$ & 4.0 & 13.5 & 7 & $8.8 \pm 0.3$ & $15.5 \pm 0.4$ & 0.80 \\
\hline ben $4 . C 29(I)$ & 4.2 & 13.5 & 7 & $9.3 \pm 0.2$ & $15.7 \pm 0.5$ & 0.85 \\
\hline ben4.D19(I) & 4.0 & 14.0 & 6 & $10.3 \pm 0.3$ & $16.2 \pm 0.4$ & 0.82 \\
\hline ben 4.D23(I) & 4.0 & 13.0 & 6 & $8.9 \pm 0.2$ & $14.5 \pm 0.5$ & 0.75 \\
\hline
\end{tabular}

Parameters shown were estimated from the primary data (see Figs. 5.1-5. for representative examples).

(1) SEM - standard error of the mean.

(2) Transition points expressed as a fraction of the complete cell cycle; the start of the cycle $=0.0$, and the termination (cell separation) of the cycle $=1.0$. 
maximum value of $10.0 \mu \mathrm{m}$ approximately three hours after shift. A sharp fall in the mean cell length of the population then occurred between three and five hours post-shift. During this period, cell division was evidently running ahead of growth. No major fluctuations in the cell length curve were seen after this time. Within eight hours the mean cell length of the wild type population appeared to attain a new steady-state value, somewhat lower than that observed before the shift. This shorter cell length was maintained throughout prolonged incubation at $20^{\circ} \mathrm{C}$ (Table 5.1).

The fluctuations in growth and division which occur in wild type cells following temperature shift down are most probably the result of a transient shock effect induced by the abrupt temperature change. A similar shock effect has been reported by Nurse et al. (1976) to occur in cultures of wild type $\underline{S}$. pombe cells when transferred from 25 to $35^{\circ} \mathrm{C}$.

\section{$5.2 \mathrm{c}$ Response of benomyl resistant cold sensitive mutants to}

temperature shift down

The physiological response of a number of the mutants isolated in this study was similarly examined. It was possible that the various mutants might each differ in their response to temperature shift down. With this in mind, a collection of eleven mutants, composed of strains with either a strong or a less pronounced cold sensitive cdc phenotype, was selected for analysis (Table 5.1). As mentioned previously, four of the twelve strains chosen, B18, D12, C23 and E14, were obtained from the initial isolation and were not genetically well characterised (section 4.5 ). The remaining seven mutants chosen for analysis were ben4.D2, D3 and C10, as well as the modifier free strains (Table 4.5) ben4.A22(I), C29(I), D19(I) and D23(I). 
In every case, the physiological response of the mutant strains to temperature shift down was markedly different from that observed in the wild type. Strains E14, C23 and the ben 4 mutants D2, D3, $A 22(I), C 29(I), D 19(I)$ and $D 23(I)$, all previously identified as exhibiting a strong $\underline{\text { cS }}$ cde phenotype, showed a similar pattern of growth and division when transferred to $20^{\circ} \mathrm{C}$. Results typical of those obtained for this group are given in Figures 5.2 and 5.3 for ben $^{4}$.D3 and strain C23 respectively. Data summarising the physiological response of the remaining mutants of this group to shift down is presented in Table 5.1 .

Cell division continued in cultures of C23 and ben4.D3 for approximately two hours after shift down (Figures 5.2 and 5.3). Following this residual increase, a long plateau in cell number occurred, lasting between six and eight hours depending on the strain under study (Table 5.1). A slight amount of division was invariably observed at the end of the plateau period. The percentage of binucleated cells fell close to zero after shift down and remained at a low level for several hours. The cessation of cell division and the accumulation of uninucleated cells in the culture suggested that the mutants were unable to complete mitosis at the restrictive temperature. Interestingly, each of the mutants from this group arrested at $20^{\circ} \mathrm{C}$ with a single aberrant nucleus, in which the chromatin region became markedly disorganised. A detailed cytological description of the nuclear arrest morphology of these mutants is presented in Chapter 6.

The prolonged inhibition of cell division in cultures of these mutants at $20^{\circ} \mathrm{C}$ was in complete contrast to the transient division block shown by the wild type strain. However, the continuous increase in mean cell length and culture turbidity throughout the cell number 


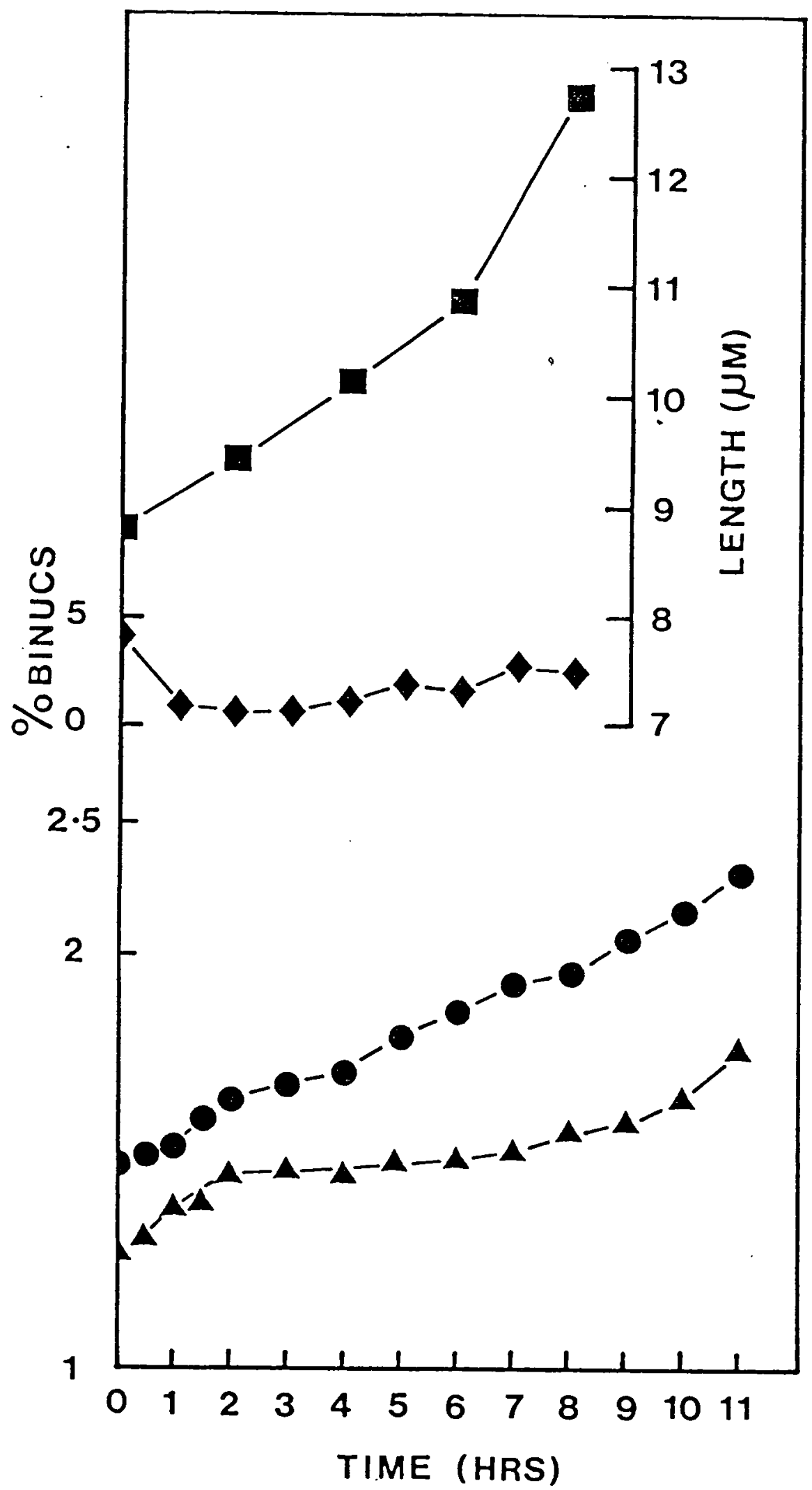

Fig. 5.2 Effect of temperature shift down on strain ben4.D3.

At time zero exponentially growing cells of strain ben4.D3 were transferred from 35 to $20^{\circ} \mathrm{C}$; samples were taken to determine: cell number $/ \mathrm{ml}(\Delta)$; frequency of binucleate cells $(\Delta)$; mean cell length $(\square)$; and turbidity $\left(A_{595 \mathrm{~nm}}\right)(\bullet)$. One unit on arbitrary $\log$ scale $=10^{6}$ cells/ml, and $0.1 A_{595 \mathrm{~nm}}$ unit. 


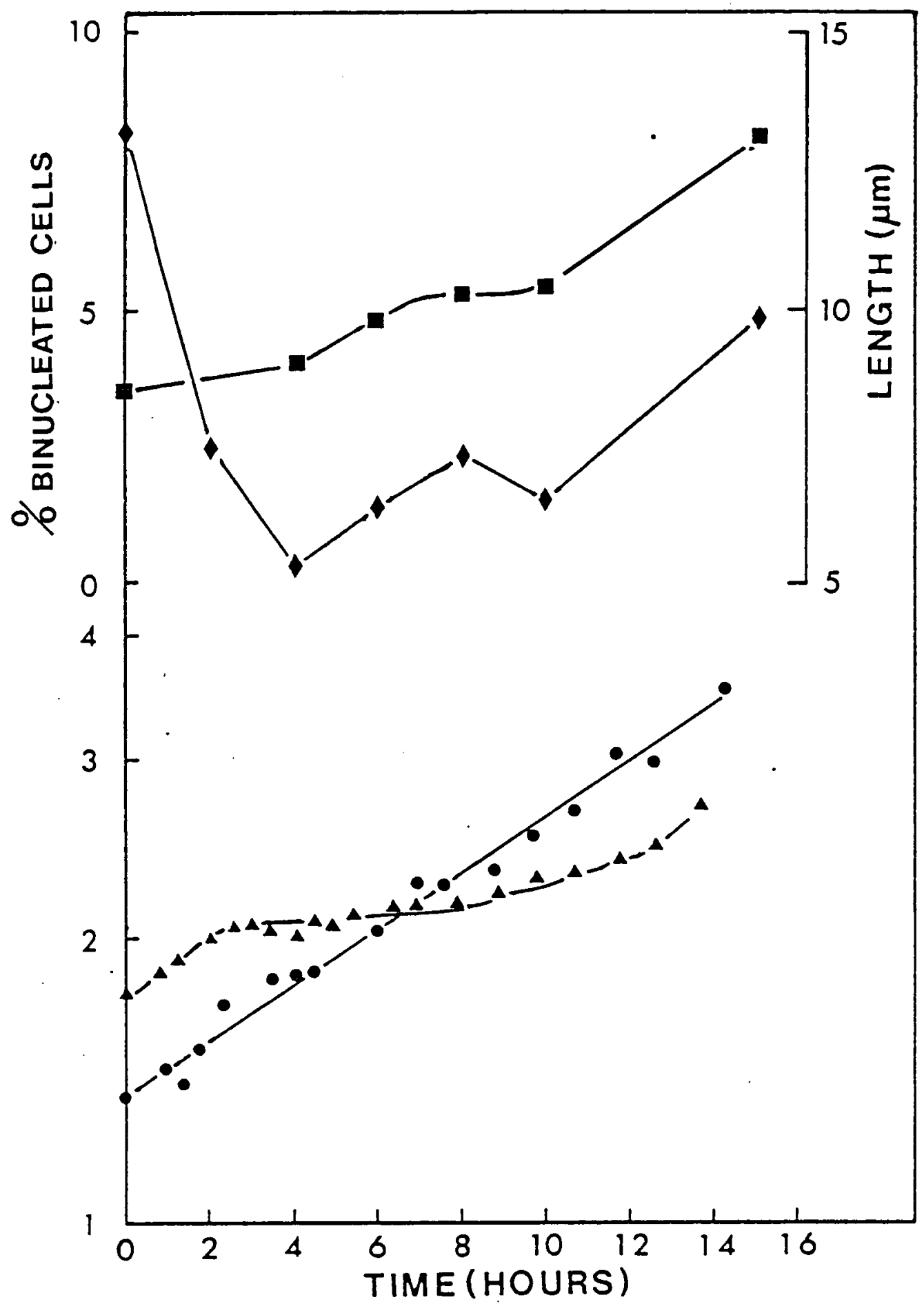

Fig. 5.3 Effect of temperature shift down on strain C23.

At time zero exponentially growing cells of strain C23 were transferred from 35 to $20^{\circ} \mathrm{C}$; samples were taken to determine: cell number/ml (4); frequency of binucleate cells ( () ; mean cell length ${ }_{6}(\boldsymbol{a})$; and turbidity $\left(A_{595 \mathrm{~nm}^{\circ}}\right)(\bullet)$. One unit on arbitrary $\log$ scale $=10^{6} \mathrm{cells} / \mathrm{ml}$, and $0.1 \mathrm{~A}_{595 \mathrm{n}}$ un 


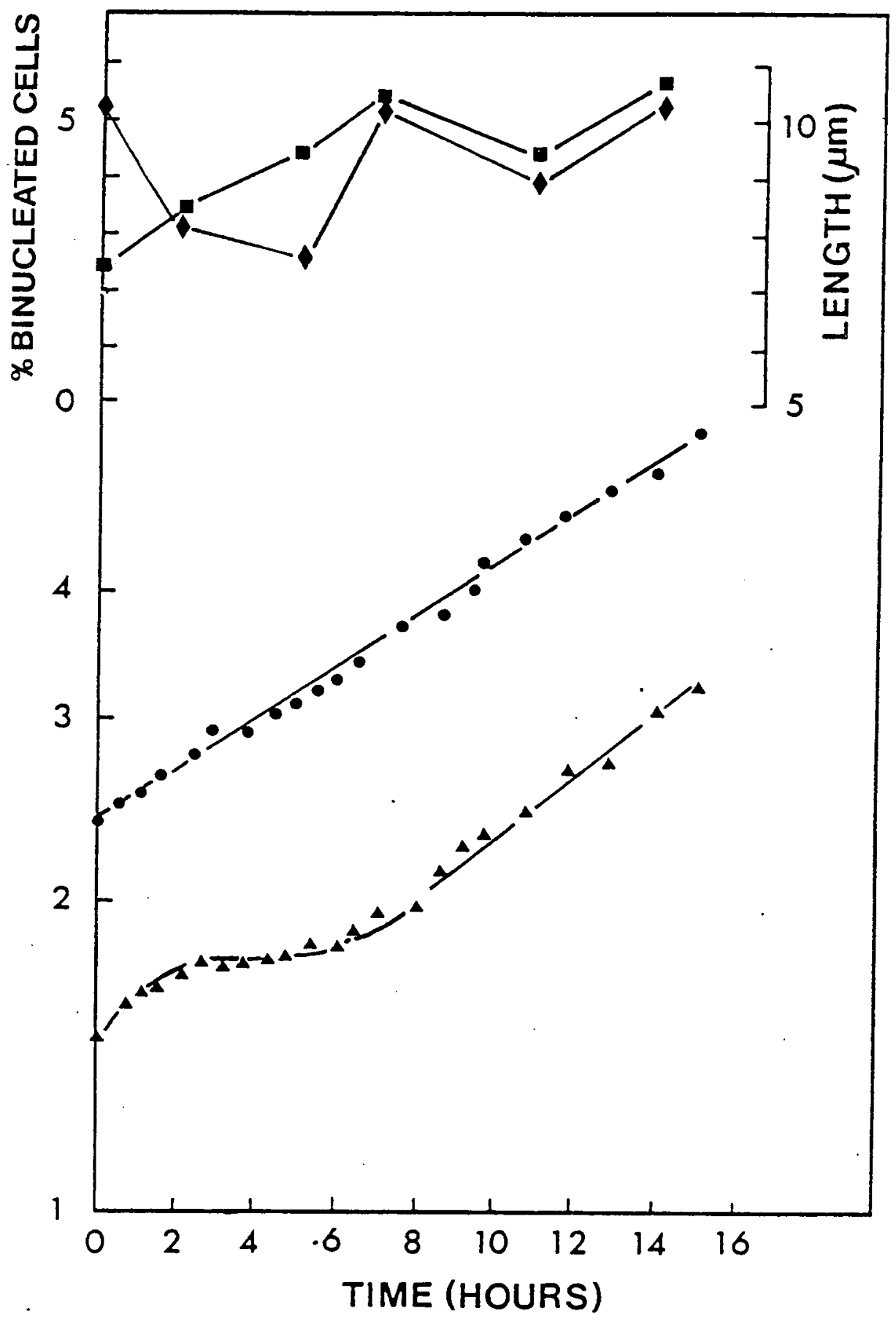

Fig. 5.4 Effect of temperature shift down on strain 012.

At time zero exponentially growing cells of strain D12 were transferred'from 35 to $20^{\circ} \mathrm{C}$; samples were taken to determine: cell number/ml (4); frequency of binucleate cells $(\downarrow)$; mean cell length $6(\boldsymbol{a})$; and turbidity $\left(A_{595 \mathrm{~nm}}\right)(\bullet)$. One unit on arbitrary log scale $=10^{6} \mathrm{cells} / \mathrm{ml}$, and $0.1 \mathrm{~A}_{595 \mathrm{~nm}}$ un 
plateau period established that cellular growth proceeded in these mutants even though cell division was inhibited (Figures 5.2 \& 5.3).

The strains B18, D12 and ben $4 . \mathrm{C} 10$, when transferred to $20^{\circ} \mathrm{C}$, showed the same basic pattern of continued growth and inhibited division as the mutants described above. In these former mutants, however, the cell number plateau was less pronounced, lasting for five hours in the case of B18 and three hours for both D12 and ben4.C10. Following shift to $20^{\circ} \mathrm{C}$, cells of B18, D12 and ben $4 . \mathrm{C} 10$ arrested with a single nucleus (e.g. Fig. 5.4). It was noticeable that in arrested nuclei of these strains the chromatin region was only partially disorganised (not shown) compared to that seen in the mutants described above. Nonetheless, the mean cell length of strains B18, D12 and ben $4 . C 10$ clearly increased with prolonged incubation at the restrictive temperature (Table 5.1), indicating that processes of cellular growth continued during the division block.

From these data it was established that each of the strongly cold sensitive mutants C23, ben4.D2, D3, A22(I), C29(I), D19(I) and $\mathrm{D} 23(\mathrm{I})$, and to a lesser extent strains B18, D12. and ben4.C10, underwent a specific block in cell cycle progress following shift to $20^{\circ} \mathrm{C}$. The accumulation of elongated cells containing a single, aberrant, nucleus (Chapter 6) was consistent with a cold sensitive defect preventing the completion of mitosis.

The concept of the transition point is of value in the characterisation of temperature conditional cdc mutants. In simple terms, a cdc mutant cell past the transition point in the cell cycle will, on shift to the restrictive temperature, be able to complete the cell cycle through to division. Conversely, a cdc mutant cell shifted to the restrictive temperature when at a cell cycle stage prior to the transition point will be unable to traverse the block imposed at 
the transition point, and so fail to divide. The transition point is regarded as the stage in the cell cycle during which the defective cdc gene product would normally complete its function (Nurse et al., 1976; Pringle, 1978). The timing of the transition point in the cell cycle may be determined from the fraction of cells able to complete division following shift to the restrictive temperature of an asynchronous culture (section 2.4a).

Each of the benomyl resistant cold sensitive mutants tested (Table 5.1) exhibited transition points within the range 0.70-0.86. This cluster of values approximates to the timing of mitosis, an event which occurs at 0.75 in the normal $\underline{s}$. pombe cell cycle (Polanshek, 1977). The transition point data was consistent with the hypothesis that the cold sensitive defect in these mutants prevented the completion of mitosis. Moreover, each of the mutants examined arrested with a single nucleus at the restrictive temperature; this phenotype

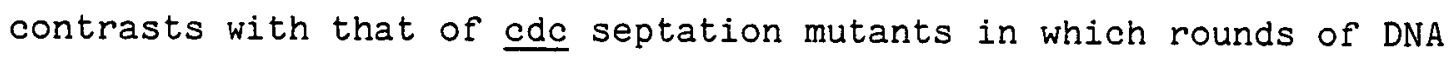
synthesis and mitosis may continue at the restrictive temperature (Nurse et al., 1976).

$5.2 d$ Recovery of mutants ben $4 . D 3$ and $C 10$

The ability of two ben 4 mutants to recover from the mitotic block imposed at the restrictive temperature was examined. Mutants ben $4 . D 3$ and $\mathrm{C} 10$ were held at $20^{\circ} \mathrm{C}$ for eight hours and six hours respectively in order to cause cell cycle arrest and, in the case of ben4.D3, induce the formation of highly aberrant nuclei in the majority of the cells (Chapter 6). A portion of each culture was then transferred to the permissive temperature and the pattern of recovery was followed by monitoring the frequency of septated cells and the behaviour of nuclei, as revealed by Giemsa staining. The results presented in Figure 5.5 demonstrate that both ben $4 . D 3$ and $C 10$ 


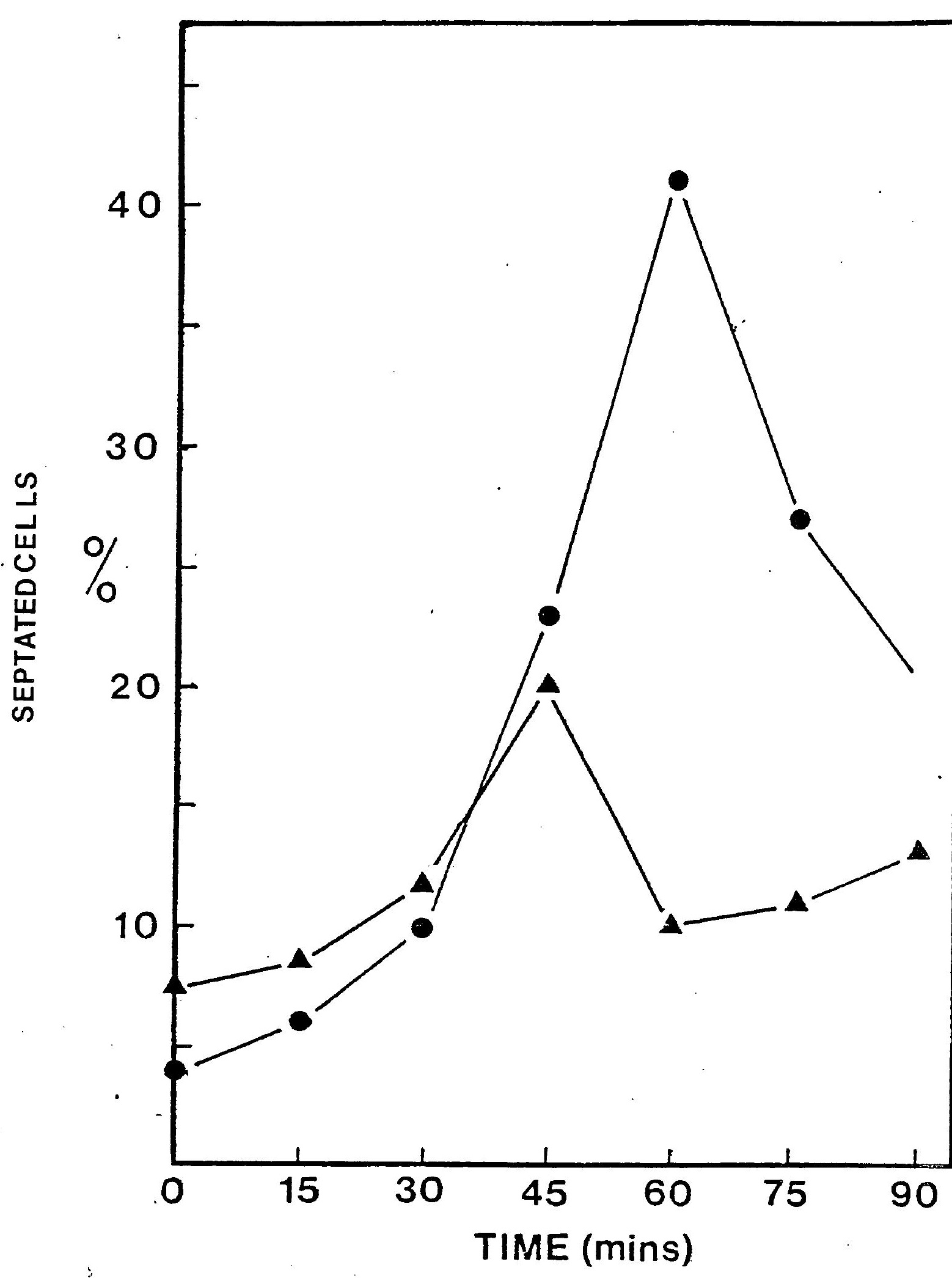

Fig. 5.5 Recovery of mutants ben4.D3 and $\mathrm{C} 10$ from division block. After six hours incubation at $20^{\circ} \mathrm{C}$, exponentially growing cells of strai ben $4 . D 3$ and ben $4 . C 10$ were transferred (at time zero) to $35^{\circ} \mathrm{C}$. Samples were taken to determine the frequency of cells containing a single Symbols: ben4.D3 ( $\bullet$; ben4.C10 (4). 
were able to recover, in a synchronous fashion, from division block. The frequency of septated ben 4.03 cells increased within fifteen minutes from transfer to $35^{\circ} \mathrm{C}$, and a peak in septated cells of over 40\% occurred one hour after shift up. In ben4.C10 cultures a less pronounced peak in the fraction of septated cells occurred after approximately 45 minutes incubation at $35^{\circ} \mathrm{C}$. This result is consistent with the observation that ben 4.010 is less completely blocked at $20^{\circ} \mathrm{C}$ than ben $4 . D 3$ (Table 5.1 ).

Examination of Giemsa stained preparations revealed that ben $4 . D 3$ and $\mathrm{C} 10$ cells, on return to $35^{\circ} \mathrm{C}$, underwent an apparently normal mitosis in which nucleolar and chromatin regions were, seemingly, correctly segregated. At the commencement of shift up, the majority of ben $4 . D 3$ cells were under division block and contained a single aberrant nucleus (section 6.3). Reorganisation of the aberrant nucleus in these cells may be necessary following shift to the permissive temperature before mitosis can take place. A detailed cytological analysis of the proposed reorganisation of the displaced nucleolar and chromatin material in these cells was not carried out; the mechanism of any such process therefore remains obscure.

Since mitosis and septum formation occur at 0.750 and 0.925 respectively in the normal $\underline{S}$. pombe cell cycle (Polanshek, 1977), an estimate of the time intervai between mitosis and septum formation in wild type cells growing at $35^{\circ} \mathrm{C}$ can be derived from the following calculation:

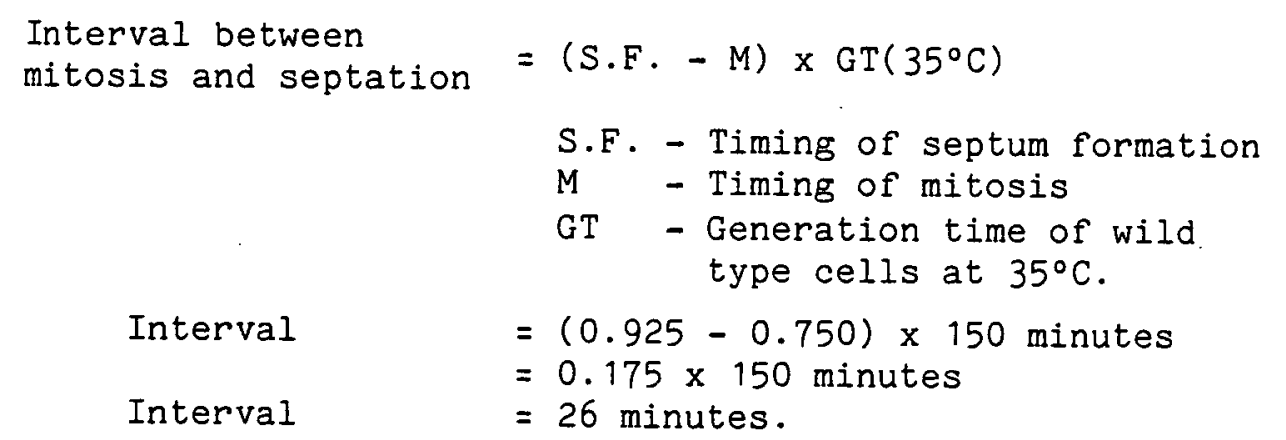


In the recovery experiments, mutants ben $4 . C 10$ and $D 3$ gave cell plate maxima approximately 45 and 60 minutes respectively after shift to $35^{\circ} \mathrm{C}$. These times are slightly longer than the normal period of the cycle between mitosis and septation of 26 minutes. The recovery data therefore provides further evidence that these mutants are specifically defective in mitosis at $20^{\circ} \mathrm{C}$. The somewhat longer recovery time of ben4.D3 cells may reflect the requirement for nuclear reorganisation prior to mitosis, as discussed above.

Although ben4.D3 cells were able to complete (apparently normally) mitosis and septation following shift to $35^{\circ} \mathrm{C}$, subsequent separation of daughter cells did not take place. This behaviour has been noted in cells of other cdc mutants when transferred back to the permissive temperature ( $P$. Fantes, personal communication) and may represent a malfunction of enzymes responsible for septum cleavage. Nevertheless, the majority of ben4.D3 cells completed a second round of mitosis and septation at $35^{\circ} \mathrm{C}$. This resulted in the formation of a fourcompartmented cell, in which each compartment contained a single, apparently normal, nucleus. It was observed that a low frequency of the second round septa were able to cleave successfully. The recovery response of ben4.D3 is represented diagramatically in Figure 5.6.

Taken overall, the results presented in the previous sections established that the ben 4 mutants, in common with the other benomyl resistant cold sensitive strains tested, arrested in or near to mitosis at $20^{\circ} \mathrm{C}$ with a single aberrant nucleus. The phenotypic properties of these mutants led to the hypothesis that the ben $4^{+}$gene product is an integral component of the mitotic machinery. 


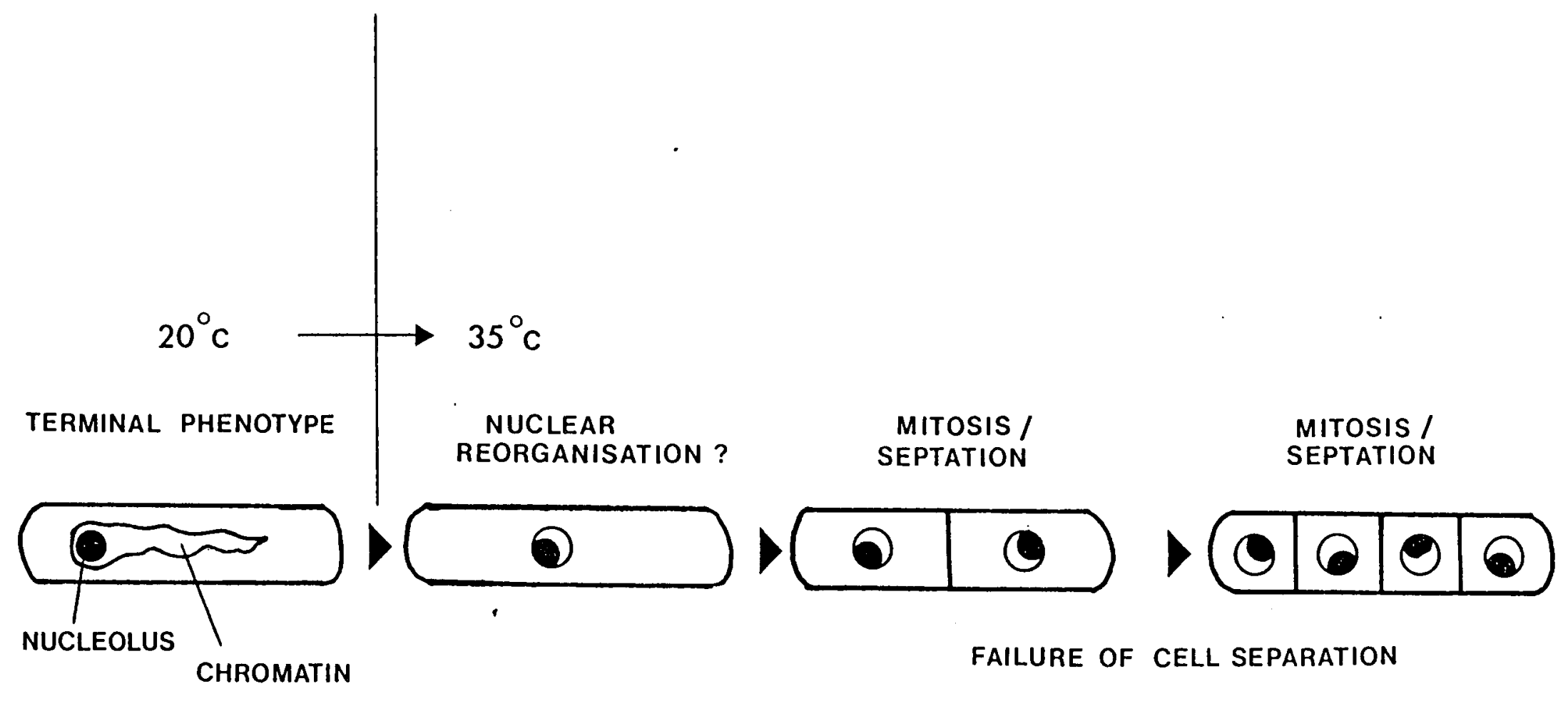

Figure 5.6 Diagramatic representation of recovery of mutant ben 4. D3 cells following shift back to the permissive temperature. 
5.3 Analysis of the drug resistance spectrum of ben 4 mutants

The cold sensitive cdc mutants isolated in this study were selected, in the first instance, as resistant to the antimitotic agent benomyl. It was considered important to analyse the drug resistance phenotype further by asking whether or not ben 4 mutants show an altered sensitivity to a range of inhibitory agents. An analysis of this sort may provide important clues concerning the molecular basis of the defect in these mutants. Two classes of compounds were used in this study. The first class included drugs with a similar structure and/or mode of action to benomyl; whilst the second class was composed of drugs with a very different structure or mode of action to benomyl. The results obtained from these sensitivity tests (carried out as described in section 2.4g) are described separately in the forthcoming sections.

The following three groups of strains were included in the tests along with the ben 4 mutants selected for study (see Tables 5.3 and 5.4): (1) the wild type strain 972; (2) JY16, 30 and 25, representative alleles of benl, 2 and 3 respectively (Yamamoto, 1980); and (3) C7, A2 and U96, representative alleles of the cycloheximide resistant mutants cyhl, 2 and 4 respectively (Ibrahim and Coddington, 1976). Analysis of the benl, 2 and 3 mutants would further describe the drug resistance spectrum of mutants originally isolated as resistant to thiabendazole (Yamamoto, 1980). The cycloheximide resistant mutants were considered to be of interest since cyhl.A2 and cyh4.U96 show resistance towards a number of inhibitors other than cycloheximide. Mutant cyhl.C7 on the other hand appears to be resistant specifically to cycloheximide (Ibrahim and Coddington, 1976). 


\section{$5.3 a$ Sensitivity of strains to antimicrotubule agents}

The growth of the strains described above was monitored in the . preșence of each of the following inhibitors: benomyl, MBC, TBZ, CIPC, nocodazole, fenbendazole, APM, griseofulvin and fluorophenylalanine (both meta and para forms). These compounds act as antimicrotubule agents in a number of different systems, and all but two of them (griseofulvin and fenbendazole) have been shown to be active against yeast. A brief summary of the inhibitory properties of these drugs pertinent to this study is given in Table 5.2 .

The drugs APM, griseofulvin, fenbendazole and fluorophenylalanine, even at the highest concentrations, had no effect on the growth of the various strains tested (Table 5.3). The finding that APM was not an effective inhibitor of growth in $\underline{s}$. pombe conflicts with the results of Walker (1982) which showed that APM at a concentration of $200 \mu g / m l$ strongly inhibited cell growth and division in this organism. It is possible that the different experimental conditions used in Walker's study may account for the conflicting results. For instance, in this latter study drug sensitivity was monitored in liquid culture, and dimethylsulphoxide was used as the carrier solvent for the drug. The growth of the wild type was not effected by nocodazole except at the highest concentration tested, at which a slight inhibition was observed. All of the other strains examined showed a similar (slight) level of sensitivity to the drug.

The drug CIPC at a concentration of $80 \mu \mathrm{g} / \mathrm{ml}$ strongly inhibited the growth of the wild type strain, and partial inhibition was observed in the presence of $60 \mu \mathrm{g} / \mathrm{ml}$ of the drug. The ben $1,2,3$ and cyh 1 and 2 mutants showed a wild type level of sensitivity to this drug, whereas mutant cyh4.U96 was somewhat more sensitive to CIPC than the wild type. Of the ben 4 mutants tested, ben 4.010 exhibited 
Table 5.2 Outline description of antimicrotubule agents employed in sensitivity tests.

\begin{tabular}{|c|c|c|c|}
\hline Drug & Common usage & Mode of action & References \\
\hline Benomyl & Fungicide & $\begin{array}{l}\text { Induces haploidization in fungi; } \\
\text { inhibits fungal mitosis. }\end{array}$ & $\begin{array}{l}\text { Fantes (1982); Orr and } \\
\text { Rosenberger (1976); Hastie (1970). }\end{array}$ \\
\hline MBC & Fungicide & $\begin{array}{l}\text { Inhibits fungal mitosis; disrupts MT } \\
\text { organisation in fungi; binds to fungal } \\
\text { tubulin. }\end{array}$ & $\begin{array}{l}\text { Quinlan et } \frac{\text { al }}{1} \cdot(1980) ; \\
\text { Kilmartin }(1981) ; \text { Howard and } \\
\text { Aist }(1980)\end{array}$ \\
\hline Nocodazole & $\begin{array}{l}\text { Anti-tumour } \\
\text { drug }\end{array}$ & $\begin{array}{l}\text { Inhibits fungal mitosis; disrupts MT } \\
\text { organisation in mammalian cells; inhibits } \\
\text { microtubule assembly in yeast. }\end{array}$ & $\begin{array}{l}\text { Hoekebe et al. (1976); Jacobs } \\
\text { and Szaniszlo }(1982) ; \text { Walker } \\
\text { (1982); Kilmartin }(1981)\end{array}$ \\
\hline Thiabendazole & $\begin{array}{l}\text { Fungicide/ } \\
\text { antihelminthic }\end{array}$ & $\begin{array}{l}\text { Inhibits yeast mitosis; disrupts } M T \\
\text { organisation in yeast; interacts with } \\
\text { fungal tubulin. }\end{array}$ & $\begin{array}{l}\text { Walker (1982); Adams and Pringle } \\
(1984) ; \text { Davidse and Flach } \\
(1978) \text {. }\end{array}$ \\
\hline CIPC & Herbicide & $\begin{array}{l}\text { Disrupts MT organisation in plant cells; } \\
\text { affects replication or separation of MTOCs; } \\
\text { pleiotropic effect on growth and division } \\
\text { in } \underline{S} \text {. pombe. }\end{array}$ & $\begin{array}{l}\text { Clayton and Lloyd ( } 1984) \text {; } \\
\text { Ciffelli (1983); Walker } \\
(1982) \text {. }\end{array}$ \\
\hline APM & Herbicide & $\begin{array}{l}\text { Inhibits tubulin synthesis in Chlamydomonas } \\
\text { reinhardij; inhibits cell division in } \underline{\text { s. pombe. }}\end{array}$ & $\begin{array}{l}\text { Collis and Weeks (1978); } \\
\text { Walker (1982). }\end{array}$ \\
\hline Griseofulvin & $\begin{array}{l}\text { Fungistatic } \\
\text { drug }\end{array}$ & $\begin{array}{l}\text { Inhibits fungal mitosis; disrupts MT } \\
\text { organisation in plant cells. }\end{array}$ & $\begin{array}{l}\text { Gull and Trinci (1973); } \\
\text { Clayton and Lloyd (1984). }\end{array}$ \\
\hline Fenbendazole & Antihelminthic & Disrupts MT organisation in nematodes. & Ireland et al. (1979). \\
\hline $\begin{array}{l}\text { m-fluorophenylalanine } \\
\text { p-fluorophenylalanine }\end{array}$ & $\overline{-}$ & Induces mitotic instability in fungi. & Kohli et al. (1977). \\
\hline
\end{tabular}


a level of CIPC sensitivity close to that of the wild type. In striking contrast, the group of strongly cold sensitive ben 4 mutants (D2, D3, A22(I), C29(I), D19(I) and D23(I) (Table 5.3) were considerably more sensitive to this drug than the wild type: complete inhibition of growth was seen with $60 \mu \mathrm{g} / \mathrm{ml}$, whilst partial inhibition occurred with $40 \mu \mathrm{g} / \mathrm{ml}$ of the drug.

It was established from experiments carried out earlier in this study (section 4.11a) that mutants ben 1, 2 and 3 exhibited a similar relative level of resistance towards $T B Z$ as that given in the original paper describing these mutants (Yamamoto, 1980). These earlier tests, in which TBZ was added to YPD agar (Table 4.8), also showed mutant ben4.C10 to be slightly more resistant to TBZ than the wild type, whereas mutant ben 4 .D3 was as sensitive as the wild type to this compound. These findings were confirmed in the TBZ sensitivity experiments conducted in this section (Table 5.3). In addition, mutants cyh1.C7 and cyh4.U96 were found to exhibit a level of TBZ sensitivity indistinguishable from that of the wild type, whereas mutant cyh2.A2 grew slightly less well than the wild type in the presence of TBZ.

The wild type strain and each of the ben 4 mutants tested showed the same relative level of sensitivity towards benomyl as that described previously (Table 3.1 and section 4.5). Mutant ben $1 . J Y 16$ was strongly resistant to benomyl, whereas ben2.JY30 and ben $3 . J Y 25$ exhibited only weak resistance to this compound. The cyh1 and cyh2 mutants were as sensitive to benomyl as the wild type strain. Interestingly, mutant cyh4.U96 exhibited a level of benomyl resistance similar to that of the ben 4 mutants. All of the strains tested had a similar degree of sensitivity towards $M B C$ as that described above for benomyl. The observation that cyh4.U96 exhibits an altered 
Table 5.3 Sensitivity of strains to antimicrotubule agents.

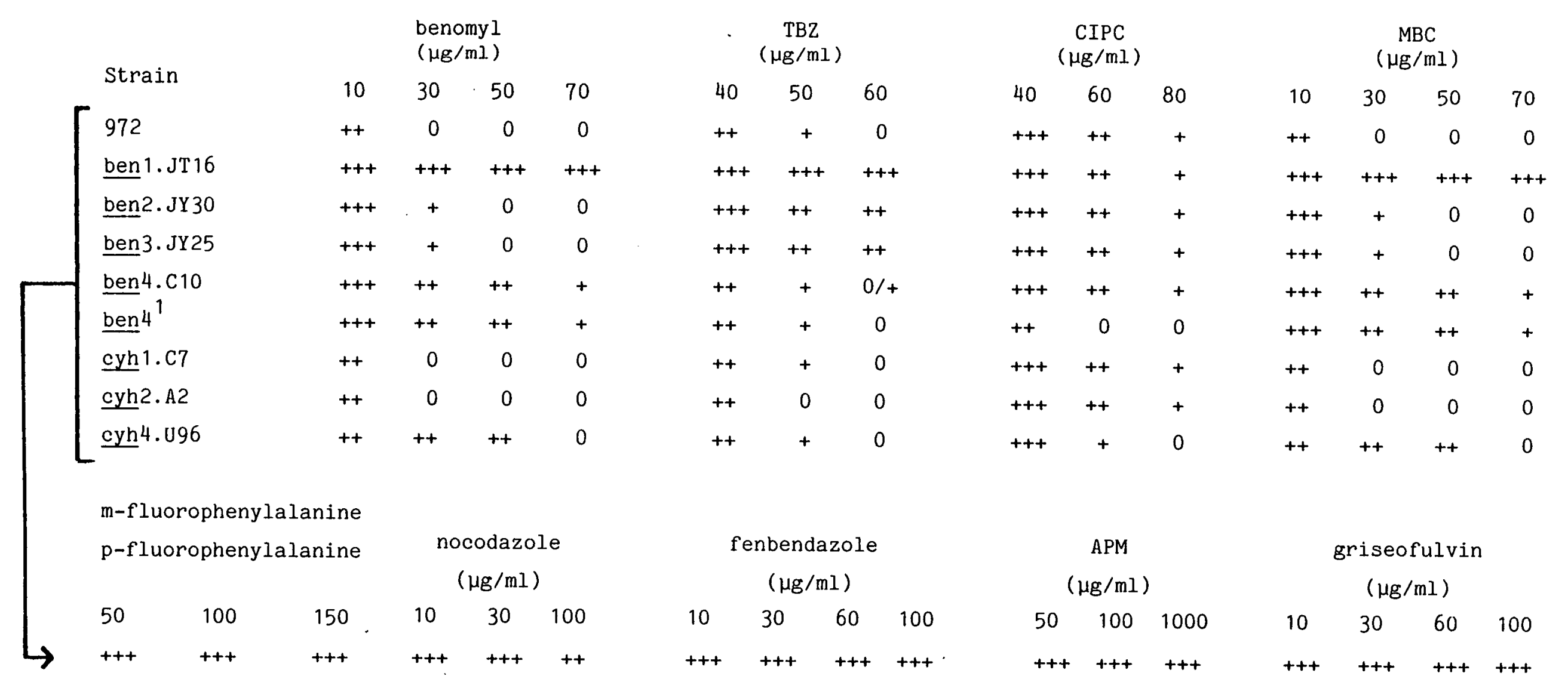

Strains were replicated to YPD agar supplemented with concentration of drug indicated. Plates were incubated at $35^{\circ} \mathrm{C}$ for three days. Growth was scored in relation to the growth of the wild type strain on YPD alone (+++ maximal; 0 zero growth).

(1) This group of mutants is composed of the following strongly cold sensitive strains: ben4.D2, D3, A22(I), C29(I), D19(I) and D23(I). 
sensitivity towards benomyl, $M B C$ and CIPC is in keeping with the finding that this mutant, although selected on the basis of cycloheximide resistance, also shows increased resistance to a number of antibiotics other than cycloheximide (Ibrahim and Coddington, 1976). The significance of this result is discussed further in Chapter 8 . $5.3 \mathrm{~b}$ Sensitivity of strains to compounds unrelated either structurally or functionally to benomyl

This section examines the sensitivity of ben 4 mutants to a variety of inhibitors which exert their effect on the growth and division of yeast in ways other than by acting as direct microtubule inhibitors. It was reasoned that these experiments might provide clues to the nature of the ben 4 defect, particularly in relation to the mechanism responsible for the drug resistance phenotype. The same collection of strains as that listed in Table 5.3 was examined in these experiments, except that only two ben 4 mutants ( 10 and D3) were included. The growth of these strains was scored in the presence of various concentrations of the following inhibitors: cycloheximide, 8-hydroxyquinoline, hydroxyurea and iodoacetate. The effect of each inhibitor is discussed in turn below, and the combined results are presented in Table 5.4 .

Cycloheximide

This compound is an inhibitor of eukaryotic protein synthesis which exerts its action by inhibition of the peptidyl transferase on the cytostolic ribosome (Alberts et al., 1983). The growth of the wild type strain was strongly inhibited in the presence of $25 \mu \mathrm{g} / \mathrm{ml}$ of cycloheximide, complete inhibition occurring with $50 \mu \mathrm{g} / \mathrm{ml}$ of the drug. Each of the ben 1, 2, 3 and 4 mutants tested showed a level of cycloheximide sensitivity indistinguishable from that of the wild type strain. The cyh mutants were all clearly cycloheximide resistant, 
exhibiting good growth at the maximum concentration of the drug tested.

\section{8-hydroxyquinoline}

This drug is a potent inhibitor of RNA synthesis in yeast (Creanor et al., 1975). The growth of the wild type strain was fully inhibited with $20 \mu g / m l$ of the drug. All of the other strains tested exhibited the same level of sensitivity to 8-hydroxyquinoline as the wild type.

\section{Hydroxyurea}

Hydroxyurea is an effective inhibitor of DNA synthesis in S. pombe (Mitchison and Creanor, 1971). The growth of the wild type was severely inhibited with $80 \mu g / m l$ of hydroxyurea, whereas near normal growth was observed with 20 and $40 \mu \mathrm{g} / \mathrm{ml}$ of the drug. Apart from the cyh 2 and ben 1 mutants, all of the strains tested showed a level of hydroxyurea sensitivity indistinguishable from that of the wild type. The ben 1 mutant was slightly more resistant to hydroxyurea, whereas cyh2.A2 was slightly more sensitive to hydroxyurea than the wild type.

\section{Iodoacetate}

Iodoacetate, an inhibitor of hexokinase, has been used extensively in the study of the yeast glycolytic pathway (Lehninger, 1975). Wild type growth was partially inhibited at the lowest iodoacetate concentration tested $(11 \mu \mathrm{g} / \mathrm{ml})$, full inhibition occurring with $55 \mu \mathrm{g} / \mathrm{ml}$ of the drug. The other strains tested were indistinguishable from the wild type on the basis of iodoacetate sensitivity.

The results presented in this section established that, with the exception of MBC, the ben 4 mutants analysed did not show significant cross resistance to any of the drugs tested, whether related or unrelated to benomyl either structurally or functionally. The 
Table 5.4 Sensitivity of strains to inhibitors unrelated to benomyl in their mode of action.

\begin{tabular}{|c|c|c|c|c|c|c|c|c|c|c|c|c|c|}
\hline \multirow[t]{2}{*}{ Strain } & \multicolumn{4}{|c|}{$\begin{array}{l}\text { cycloheximide } \\
(\mu \mathrm{g} / \mathrm{ml})\end{array}$} & \multicolumn{3}{|c|}{$\begin{array}{l}\text { 8-hydroxyquinoline } \\
\qquad(\mu \mathrm{g} / \mathrm{ml})\end{array}$} & \multicolumn{3}{|c|}{$\begin{array}{l}\text { hydroxyurea } \\
(\mu g / \mathrm{ml})\end{array}$} & \multicolumn{3}{|c|}{$\begin{array}{l}\text { iodoacetate } \\
\qquad(\mu \mathrm{g} / \mathrm{ml})\end{array}$} \\
\hline & 0 & 5 & 25 & 50 & 5 & 20 & 50 & 20 & 40 & 80 & 11 & 36 & 55 \\
\hline 972 & +++ & +++ & + & 0 & +++ & 0 & 0 & +++ & +++ & + & ++ & + & 0 \\
\hline ben $1 . J Y 16$ & +++ & +++ & + & 0 & +++ & 0 & 0 & +++ & +++ & ++ & ++ & + & 0 \\
\hline ben2. JY30 & +++ & +++ & + & 0 & +++ & 0 & 0 & +++ & +++ & + & ++ & + & 0 \\
\hline ben $3 . J Y 25$ & +++ & +++ & + & 0 & +++ & 0 & 0 & +++ & +++ & + & ++ & + & 0 \\
\hline ben $4 . C 10$ & +++ & +++ & + & 0 & +++ & 0 & 0 & +++ & +++ & + & ++ & + & 0 \\
\hline ben $4 . D 3$ & +++ & +++ & + & 0 & +++ & 0 & 0 & +++ & +++ & + & ++ & + & 0 \\
\hline cyh $1 . C 7$ & +++ & +++ & +++ & +++ & +++ & 0 & 0 & +++ & +++ & + & ++ & + & 0 \\
\hline cyh2.A2 & +++ & +++ & ++ & ++ & +++ & 0 & 0 & +++ & +++ & 0 & ++ & + & 0 \\
\hline cyh4.U96 & +++ & +++ & ++ & ++ & +++ & 0 & 0 & +++ & +++ & + & ++ & + & 0 \\
\hline
\end{tabular}

Strains were replicated to YPD agar supplemented with the concentration of drug indicated. Plates were incubated at $35^{\circ} \mathrm{C}$ for three days. Growth was scored in relation to growth of the wild type on YPD alone. (+++ maximal; 0 zero growth). 
spectrum of drug resistance exhibited by the ben 4 mutants appeared to be narrow, and in these tests was restricted to benomyl and its breakdown product $M B C$. It was perhaps surprising then to find that the group of strongly cold sensitive mutants was considerably more sensitive to CIPC than the wild type. The CIPC sensitivity exhibited by this group of mutants has recently been confirmed by Ciffelli (1983). She found that the growth and division of ben4.D3 cells in liquid culture was severely inhibited with $30 \mu \mathrm{g} / \mathrm{ml}$ of the drug, whereas a CIPC concentration of at least $60 \mu \mathrm{g} / \mathrm{ml}$ was required to induce a similar level of inhibition in wild type cells. Some of the possible implications arising from the CIPC supersensitivity exhibited by this group of ben 4 mutants are discussed in Chapter 8 .

5.4 Physiological response of hsR5 and hsR10 to temperature shift up Mutants $\underline{h s} R 5$ and $\underline{h s} R 10$ were isolated as resistant to benomyl at $20^{\circ} \mathrm{C}$. These mutants also exhibit a heat sensitive cdc phenotype when incubated at $35^{\circ} \mathrm{C}$ in the absence of benomyl (section $4.14 \mathrm{~b}$ ). The nature of the cdc phenotype of these mutants was investigated further in temperature shift experiments, the transfer performed being from 20 to $35^{\circ} \mathrm{C}$. As before, it was first necessary to describe the response of the wild type strain to temperature shift up.

\section{$5.4 a$ Response of strain 972 to temperature shift up}

The pattern of cell growth and division observed in the wild type culture following shift to $35^{\circ} \mathrm{C}$ is given in Figure 5.7 . Cell division continued for about 1.5 hours after shift up, whereupon a transient plateau in cell number increase occurred. A fall in the percentage of septated cells, which coincided with the brief cell number plateau, occurred shortly after shift up. The fraction of septated cells then increased, in concert with the resumption of cell 


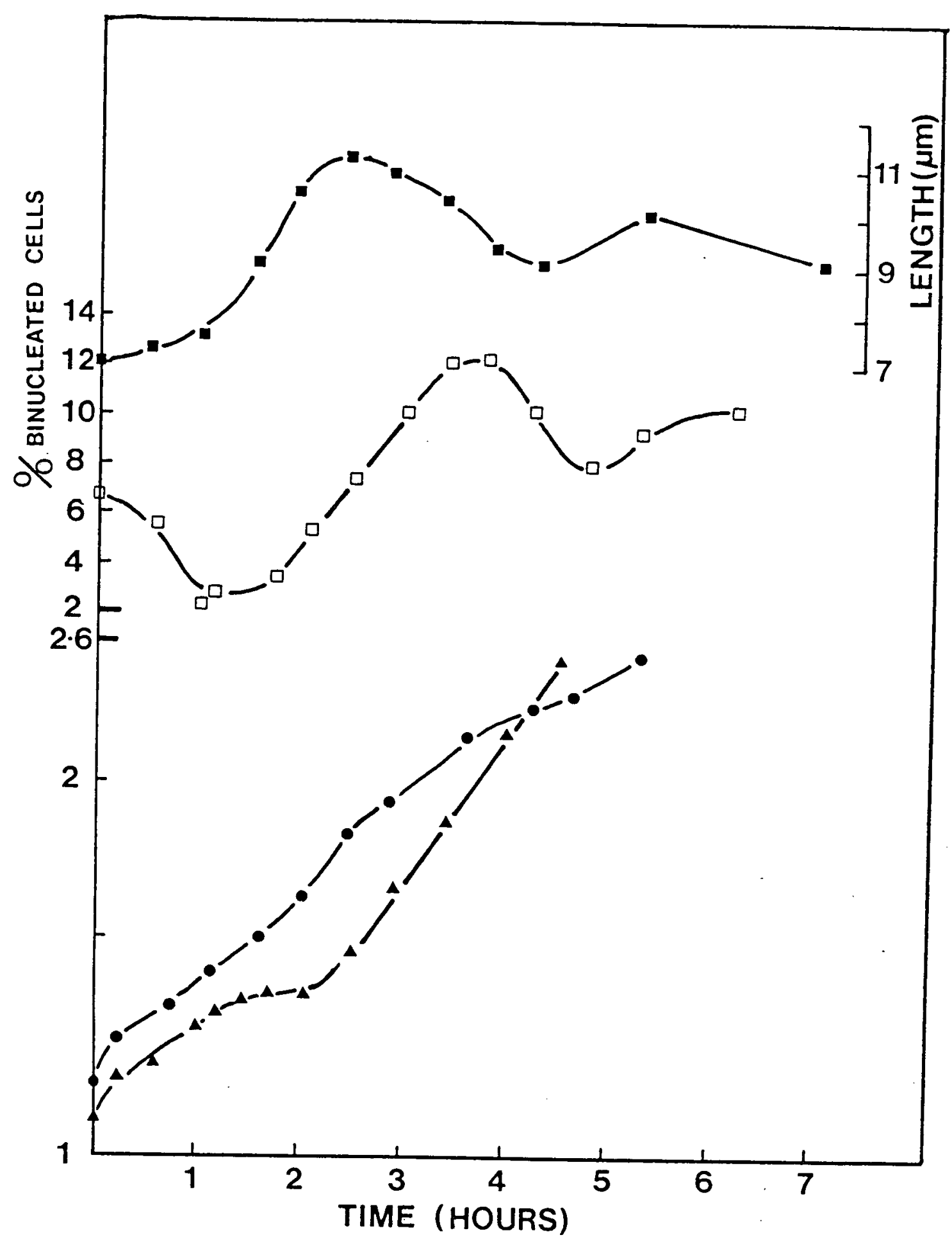

Fig. 5.7 Effect of temperature shift up on strain 972 .

At time zero exponentially growing cells of strain 972 were transferred from 20 to $35^{\circ} \mathrm{C}$; samples were taken to determine: cell number/ml (4) turbidity $\left(A_{595 \mathrm{~nm}}\right)(\bullet)$; frequency of septated cells $(\square)$; and mean cell One unit on arbitrary $\log$ scale $=10^{6} \mathrm{cells} / \mathrm{ml}$, and $0.08 \mathrm{~A}_{595 \mathrm{~nm}}$ unit. 
division following the transient division block. The frequency of septated cells reached a maximum of around $13 \%$ approximately four hours post-shift, and no major fluctuations in this parameter were observed for the remainder of the experiment. The mean cell length of the population increased continuously until the end of the transitory cell number plateau, whereupon a gradual fall in mean cell length occurred, coincident with the increased cell division rate of the culture at this time. The mean cell length of the population eventually reached a value close to that characteristic of growth at $35^{\circ} \mathrm{C}$ (Table 5.1). Throughout the duration of the experiment culture turbidity increased continuously. The data presented above established that wild type cells undergo a transitory division block following temperature shift up but resume steady state growth and division under the new conditions soon thereafter.

5.4b Response of hsR10 to temperature shift up

The response of mutant hsR 10 to temperature shift up is presented in Figure 5.8. Cell growth and division continued for a short time following transfer to $35^{\circ} \mathrm{C}$. As can be seen from the simultaneous plateaux in the cell number and turbidity curves, a cessation of growth and division occurred after the initial increase. The mean cell length of the culture increased only slightly during this period of inhibited growth and division. The frequencies of binucleated and of septated cells fell to low values shortly after shift, reflecting the simultaneous inhibition of growth and division which occurred at this time. Cell growth and division resumed in the culture after approximately four hours. The physiological response of hsR10 cells following shift to the restrictive temperature was unlike the response of the cold sensitive cdc mutants isolated and examined in this study. Most notably, the heat sensitive defect in 


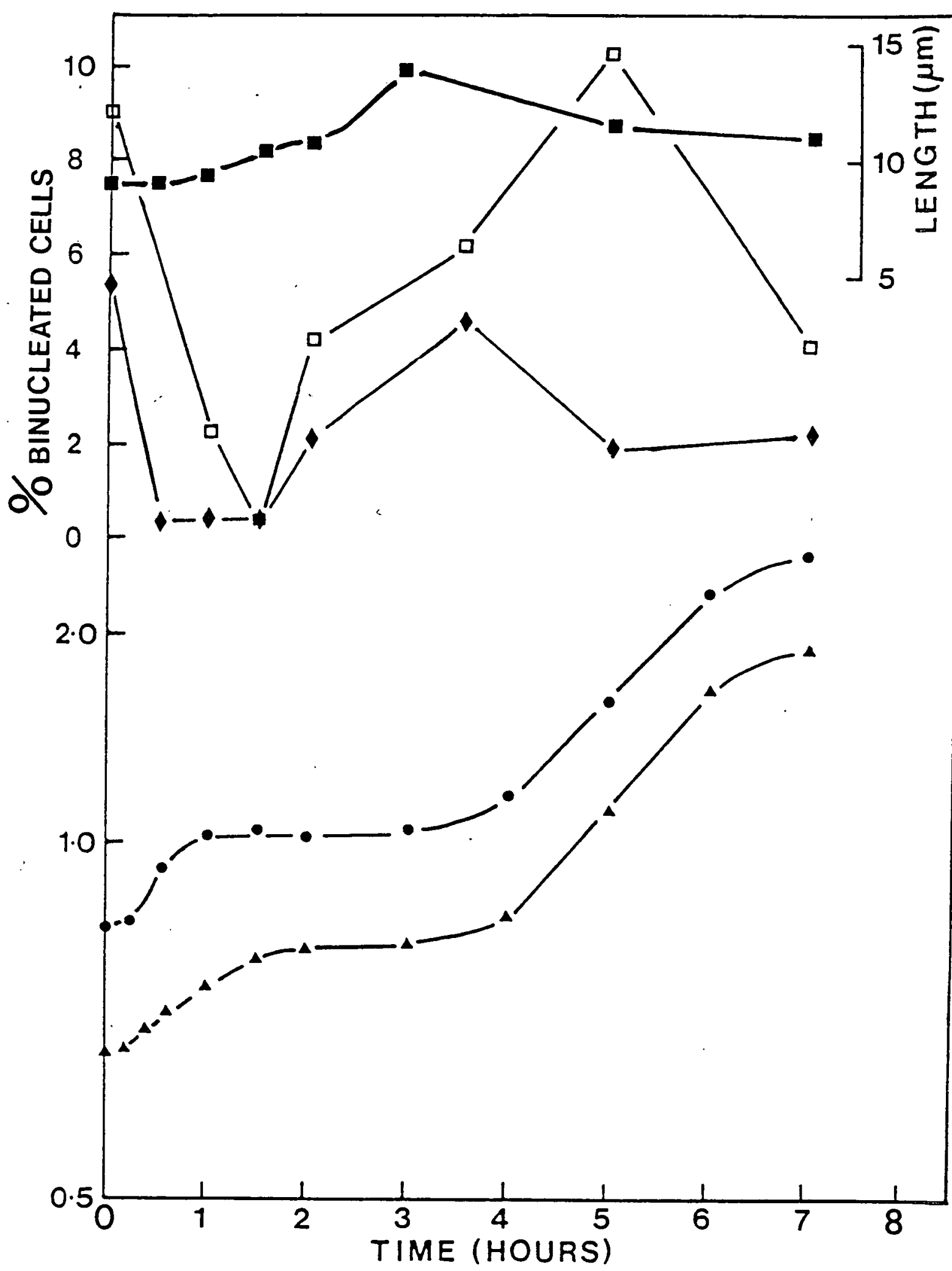

Fig. 5.8 Effect of temperature shift up on strain hsR10.

At time zero exponentially growing cells of strain hsR 10 were transferred from 20 to $35^{\circ} \mathrm{C}$; samples were taken for: cell number/ml (A); turbidity $\left(A_{595 \mathrm{~nm}}\right)(\bullet)$; frequency of binucleated cells $(\$)$; mean cell length (a). $595 \mathrm{~nm}$. and frequency of septated cells ( $\square$ ) One unit on arbitrary $\log$ scale $=10^{6} \mathrm{cells} / \mathrm{ml}$, and $0.1 \mathrm{~A}_{595 \mathrm{~nm}}$ unit. 
hsR 10 cells inhioited both cellular growth and division for at least four hours following temperature shift up: cellular growth and division resumed in the culture after this time. It was noticeable, however, that mutant hsR10 exhibited severely reduced bulk growth following overnight incubation on EMM agar at $35^{\circ} \mathrm{C}$, and cellular elongation was only slight under these conditions. One'possibility, not tested here, is that hsR10 cells undergo a secondary inhibition of growth and division following prolonged incubation at $35^{\circ} \mathrm{C}$. The simultaneous inhibition of cellular growth and division at the restrictive temperature means that hsR10 cannot be considered as a true cde mutant, using the criterion adopted in this study.

$5.4 \mathrm{c}$ Response of mutant hsR5 to temperature shift up

Cell division continued in cultures of hsR5 cells for approximately 1.5 hours after transfer to the restrictive temperature (Figure 5.9). Following this residual increase, cell division ceased in the culture for at least six hours, after which time a slight amount of division was observed. The continuous increase in both mean cell length and culture turbidity throughout the experiment established that processes of cellular growth occurred during the period of the division block. The frequencies of septated and binucleated cells fell to low levels shortly after temperature shift up (Figure 5.9), a response characteristic of cells undergoing a mitotic block. The transition point of 0.64 calculated for hsR5 was consistent with a mitotic defect. Further evidence in support of this hypothesis was obtained from a cytological examination of the terminal phenotype. After approximately four hours incubation at $35^{\circ} \mathrm{C}$, the nuclear material of arrested hsR5 cells formed into a number of discrete chromatinic bodies. These bodies were considered to represent condensed chromosomes, and a description of the typical 


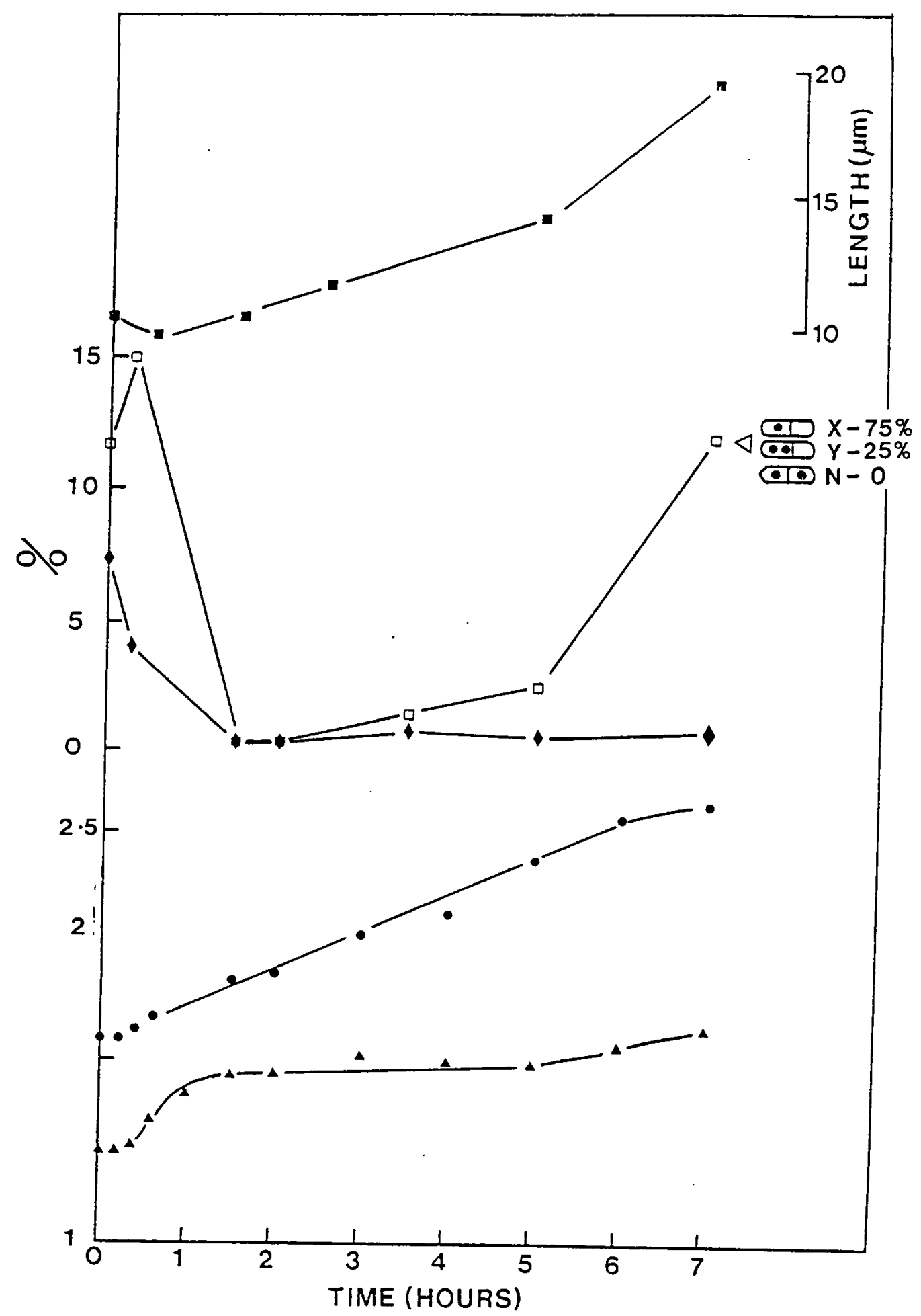

Fig. 5.9 Effect of temperature shift up on strain hsR5.

At time zero exponentially growing cells of strain hsR5 were transferred from 20 to $35^{\circ} \mathrm{C}$; samples were taken to determine: cell number/ml (A); turbidity $\left(A_{595 \mathrm{~nm}}\right)(\bullet)$; frequency of binucleated cells $(\diamond)$; mean cell

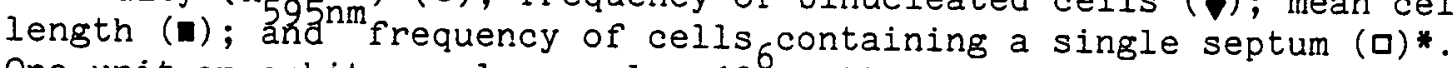
One unit on arbitrary $\log$ scale $=10^{6} \mathrm{cells} / \mathrm{ml}$, and $0.1 \mathrm{~A}_{595 \mathrm{~nm}}$ unit. * Note: Cells containing a single septum began to accumulate in the culture approximately five hours after shift. The distribution of nuclei in these cells was, however, very different from that seen in the wild type. The frequency of each of the two aberrant cell types found (represented diagramatically) is given for the final time point (see text, section $\mathbf{H}^{\mathrm{C}}$ ).

(1) X - Type X cells; Y - Type Y cells; N - normal.. 
morphologies observed is provided in section 6.8 .

Around five hours post-sift the frequency of septated cells in the culture increased, and within seven hours $14 \%$ of cells contained a single septum. Following sixteen hours incubation at $35^{\circ} \mathrm{C}$ approximately $80 \%$ of cells in the culture were septated (data not shown). This result established that cell separation failed to take place following septation. Interestingly, the fraction of binucleated cells fell close to zero after shift up and stayed at a low level for the remainder of the experiment (Figure 5.9), even though the frequency of septated cells increased during this time. Consequently, seven hours after shift $75 \%$ of septated hsR5 cells contained but a single nucleus (Figure 5.9). The single nucleus in these cells was found to reside in one of the two cytoplasmic compartments formed by the septum; cells with this morphology were designated Type $\mathrm{X}$ cells. The remaining $25 \%$ of septated cells scored at the seven hour time point apparently contained two nuclei. In these cells, designated Type $Y$ (Figure 5.9), both nuclei were localised to one of the two cytoplasmic compartments. None of the septated cells scored at this time point contained a single nucleus within each cytoplasmic compartment, as normally observed in the cell cycle of this organism. A reasonable assumption to make a priori is that the anucleate compartment formed in Type $X$ and Type $Y$ cells would be inviable. This would provide an explanation for the strong uptake of magdala red into one of the two cytoplasmic compartments present in arrested hsR5 cells following long term incubation at $35^{\circ} \mathrm{C}$ on agar medium containing the dye (section 4.14b). A cytological description of Type $X$ and Type $Y$ hsR5 cells is presented in section 6.8 , together with a discussion of possible mechanisms to account for their formation. 


\section{Chapter 6}

\section{CYTOLOGICAL CHARACTERISATION}

\subsection{Introduction}

As discussed in Chapter 1, a cytological analysis of the terminal phenotype forms an integral part in the characterisation of a cdc mutant. By observing which major cell cycle events do or do not occur in a cdc mutant following shift to the restrictive temperature one may obtain clues as to process primarily defective under these conditions. In this respect, cytological analysis of the terminal phenotype has been particularly rewarding when applied to cde mutants defective in morphologically well defined events of the cell cycle such as mitosis or septation.

This chapter provides a detailed cytological description of the terminal phenotype expressed by several of the strongly cold sensitive ben 4 mutants. In addition, the terminal phenotype exhibited by the heat sensitive mitotic mutant $\underline{h s} \mathrm{R} 5$ is described. The final section of this chapter describes the curious morphology attained by certain ben 4 cdc double mutants following incubation at $35^{\circ} \mathrm{C}$.

Despite their popularity for biochemical and genetical studies yeast have proved rather intractable in cytological work for a number of reasons. Firstly, the relatively small size of yeast cells renders discrimination of cellular components less easy than in higher eukaryotes. Secondly, a substantial wall surrounds yeast cells, and this structure must be removed enzymatically in certain procedures to allow penetration of stains or to improve sectioning quality. Thirdly, and of particular relevance to this study, is that mitosis in yeast takes place in a relatively simple fashion: there are none of the dramatic structural changes seen in the nuclei of higher cells 
undergoing mitosis. For instance, there is neither breakdown of the nuclear membrane nor discernable condensation of nuclear material during the normal course of mitosis in $\underline{\mathrm{S}}$. pombe (McCully and Robinow, 1971; Toda et al., 1981). Another drawback to the cytological study of mitosis in $\underline{S}$. pombe is the transitory nature of the event: the combined stages of anaphase and telophase occupy only about $5 \%$ of the cell cycle in this organism ( $J$. M. Mitchison, personal communication).

\subsection{Cytological analysis of ben 4 mutants}

The physiological and preliminary cytological evidence presented in the previous chapter established that the ben 4 mutants analysed were defective in mitosis at the restrictive temperature. Those ben 4 mutants which exhibited a strongly cold sensitive cde defect (section $5.2 \mathrm{c}$ ) arrested at $20^{\circ} \mathrm{C}$ with a single aberrant nucleus. The morphology of the aberrant nucleus was similar in each case: the nucleolus appeared to remain compact, whereas the chromatin-rich region became elongated and disorganised within the cell. An extensive cytological characterisation of the terminal phenotype exhibited by several of these ben 4 mutants was undertaken, paying particular attention to the nature of the aberrant nuclear morphology. It was considered important to employ a number of different cytological techniques in this study in order to increase the range of cellular components available for study, and also to counteract arguments concerning the induction of cytological artifacts due to specimen preparation. Five separate techniques were used; four of these were light microscopical methods, utilising the following stains: (1) Giemsa's stain; (2) acid fuschin; (3) DAPI; and (4) ethidium bromide. The fifth approach involved characterisation at the ultrastructural level with transmission electron microscopy. 
For each technique used, control observations were made on ben 4 mutants cultured at the permissive temperature $\left(35^{\circ} \mathrm{C}\right)$ and also on wild type cells incubated at 35 and $20^{\circ} \mathrm{C}$. From the outset it should be stated that, at $35^{\circ} \mathrm{C}$, the cellular and nuclear morphology of each ben 4 mutant tested was closely similar to that of wild type cells when incubated at either 35 or $20^{\circ} \mathrm{C}$. Reiteration of this observation will not be made in the following text. The description of the wild type strain applies to cells incubated at $35^{\circ} \mathrm{C}$ unless otherwise stated.

The following three mutants were selected for analysis: ben4.D3, $C 29(I)$ and $D 19(I)$. This study established that the nature of the terminal phenotype exhibited by these mutants was similar in each case. Therefore, ben4.D3 will be used as a representative example in the ensuing description. For each technique employed, a cytological description of the wild type is first given; this is followed by a description of the terminal phenotype of the ben 4 mutants analysed.

\subsection{Giemsa staining}

Giemsa's stain is a widely used differential nucleic acid stain. However, in order to obtain clear staining of yeast nuclei a harsh procedure involving heat and chemical fixation followed by either an acid (Nurse et al., 1976) or a salt (McCully and Robinow, 1971) extraction step to remove cytoplasmic RNA is required.

\section{3a Cytology of wild type cells}

In suitably stained preparations of wild type cells it was possible to differentiate between the two major components of the interphase nucleus: nucleolus and chromatin. These two regions can be distinguished in the colour micrographs presented in Plate 6.1a. The nucleolus was visualised as a compact pink-staining body, closely associated with the bluish-purple staining chromatin region. 


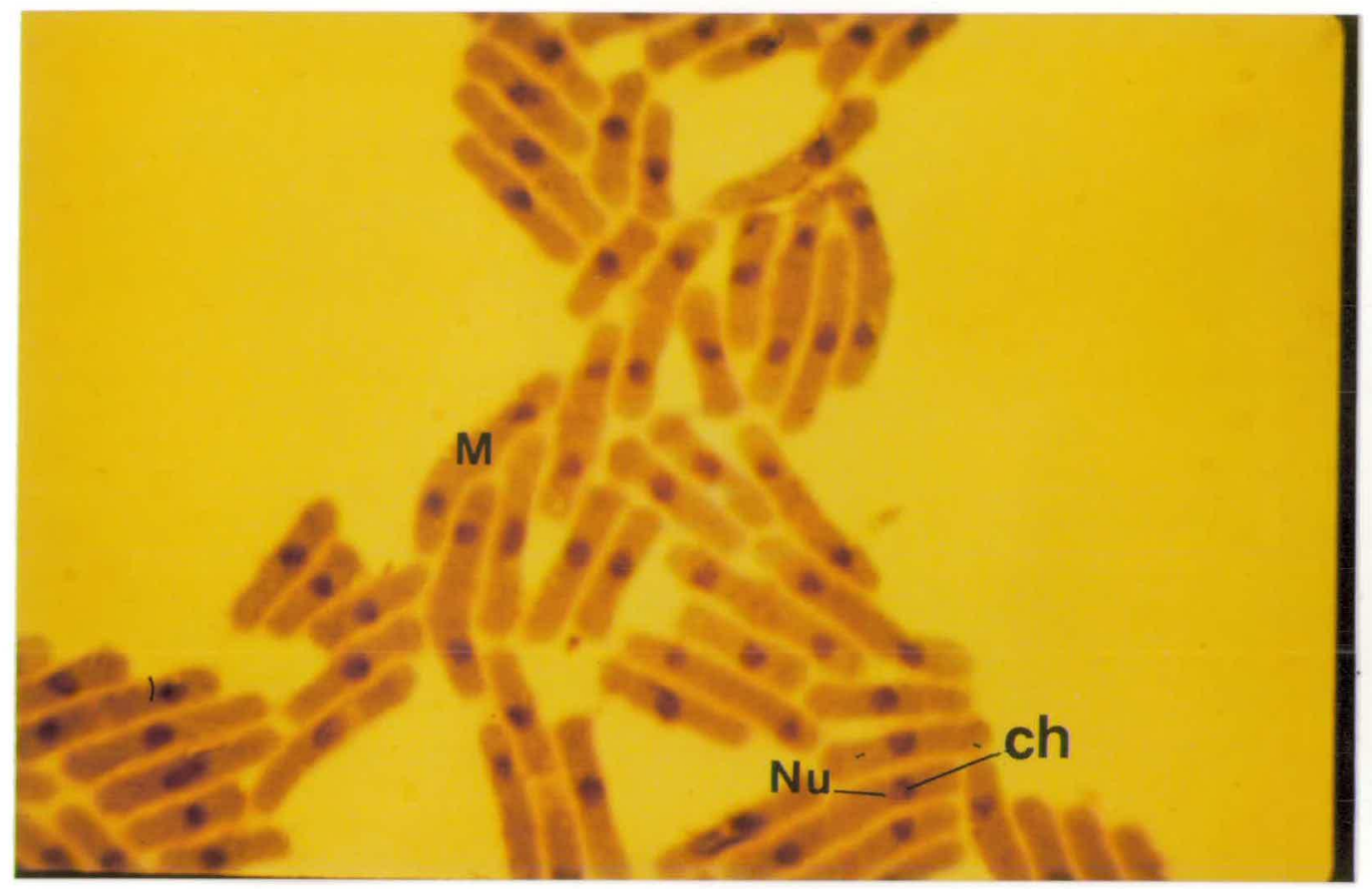

Plate 6.1a Wild type cells. Giemsa staining. Note: Nucleolus (Nu); Chromatin ( $\mathrm{Ch}$ ) and cells undergoing mitosis.(M).

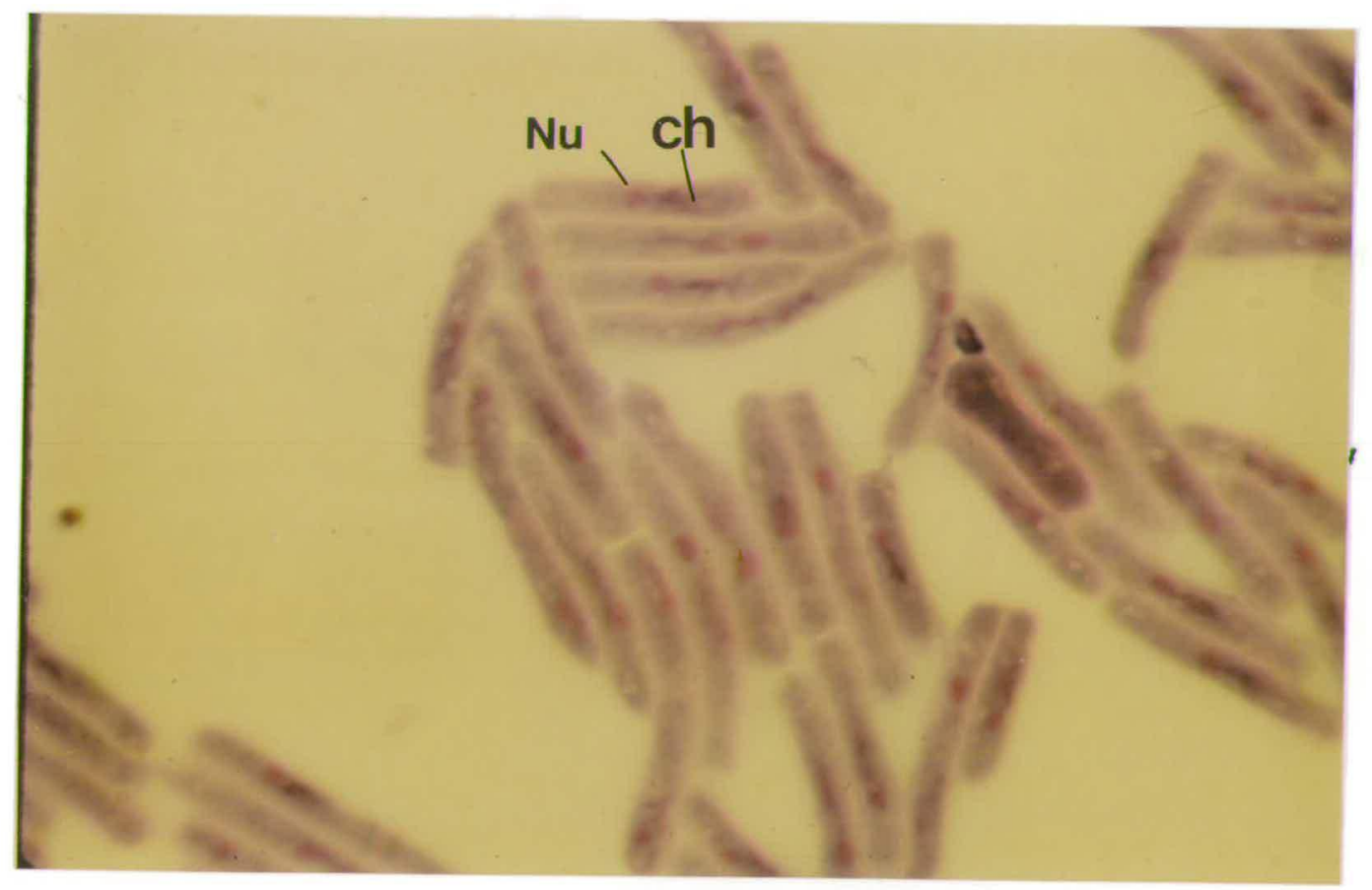

Plate $6.1 \mathrm{~b}$ Giemsa stained preparation of ben4.D3 cells following 10 hours incubation at $20^{\circ} \mathrm{C}$. Note: Nucleolus (Nu); Chromatin ( Ch). 


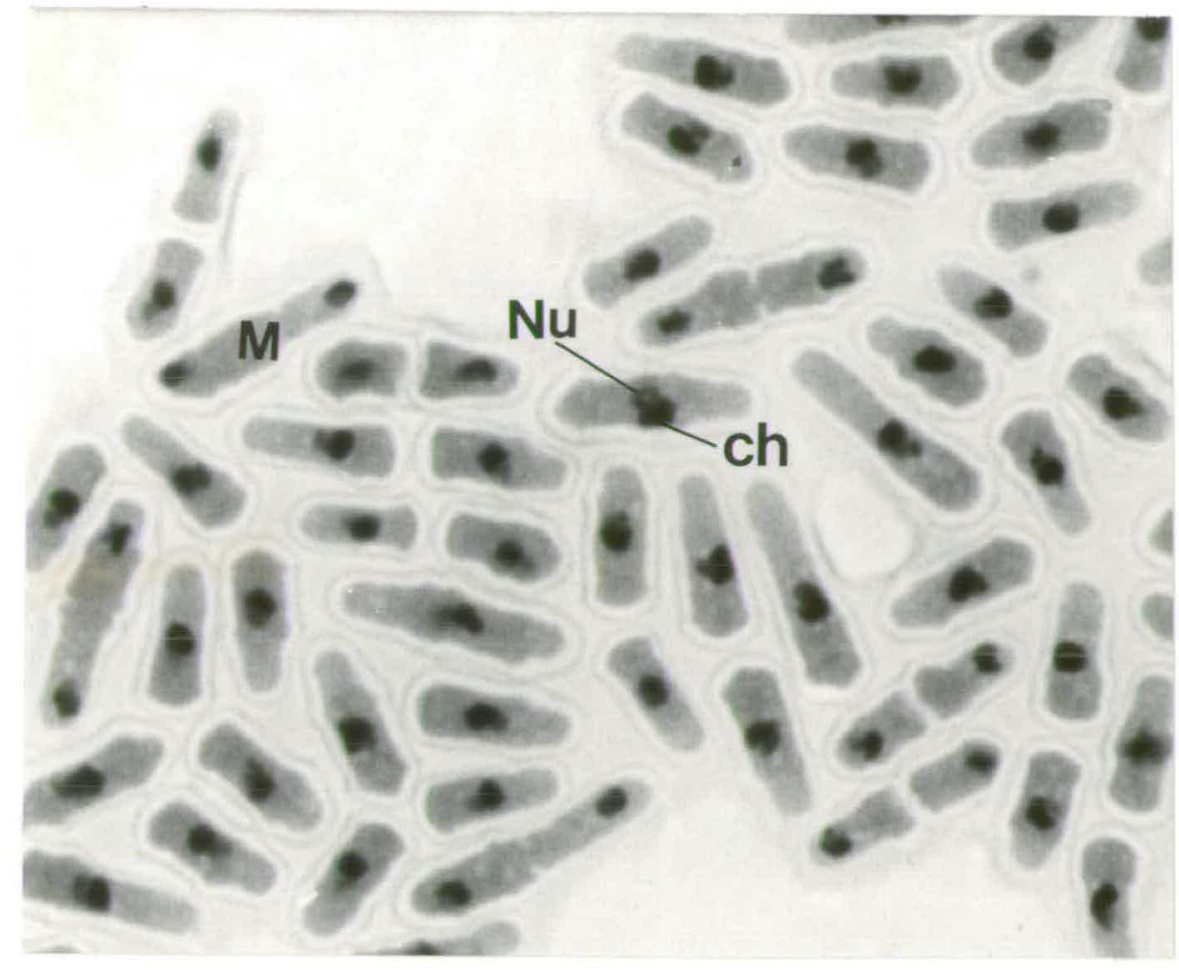

Plate 6.2a Wild type cells. Giemsa staining. Note: Nucleolus (Nu); Chromatin $(\mathrm{Ch})$ and cells undergoing mitosis (M).

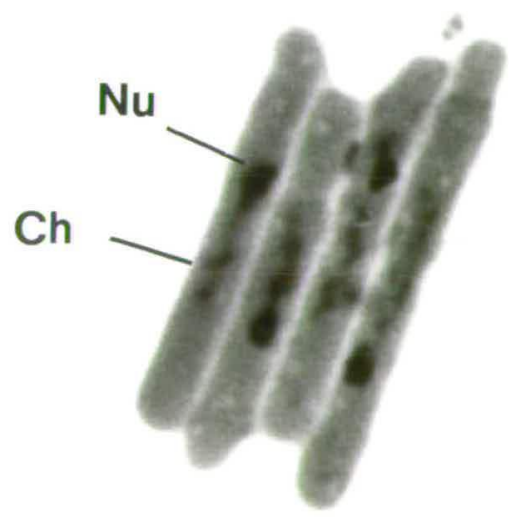

Plate 6.2b Giemsa stained preparation of ben4.D3 cells following 10 hours incubation at $20^{\circ} \mathrm{C}$. Note: Nucleolus ( $\left.\mathrm{Nu}\right)$; Chromatin ( Ch). 
Discrimination between these nuclear components can also be made from the half-tone micrographs presented in Plate $6.2 a$. Here, chromatin and nucleolar regions are recognised as the dark and light staining components respectively. Cells undergoing various stages of mitosis were clearly seen in these preparations (Plates $6.1 \mathrm{a}$ and $6.2 \mathrm{a}$ ).

$6.3 b$ Cytology of the terminal phenotype of ben 4 mutants

Giemsa staining revealed that each ben 4 mutant examined arrested with a single aberrant nucleus following prolonged incubation at $20^{\circ} \mathrm{C}$ (Plates $6.1 \mathrm{~b}$ and $6.2 \mathrm{~b}$ ). In these cells, the nucleolus was clearly visualised as a spherical pink-staining body, located, commonly, towards one end of the much elongated cell (Plates 6.1b and 6.2b). In contrast, the bluish-purple staining chromatin region was found to be elongated and disorganised within the cell. Nevertheless, the chromatin appeared to maintain a tenuous attachment to the nucleolus (Plates $6.1 \mathrm{~b}$ and $6.2 \mathrm{~b}$ ). The orientation of the disorganised chromatin was similar in each mutant analysed: the chromatin ran from its point of apparent attachment to the nucleolus towards the opposite end of the cell.

A time-course study was employed to monitor the rate of nuclear disorganisation in ben $4 . D 3$ cells following shift to the restrictive temperature. Two hours after transfer to $20^{\circ} \mathrm{C}$ the chromatin region appeared to separate from the nucleolus as a discrete entity (Plate 6.3a), and within five hours considerable nuclear disorganisation had taken place (Plate $6.3 \mathrm{~b}$ ). Chromatin disorganisation was extensive seven hours post-shift, and the nucleolus was found to occupy a near terminal position within a proportion of the cells (Plate $6.3 \mathrm{c}$ ). The majority of cells in the population attained the characteristic terminal phenotype within ten hours from termperature shift down (Plate 6.3d). 

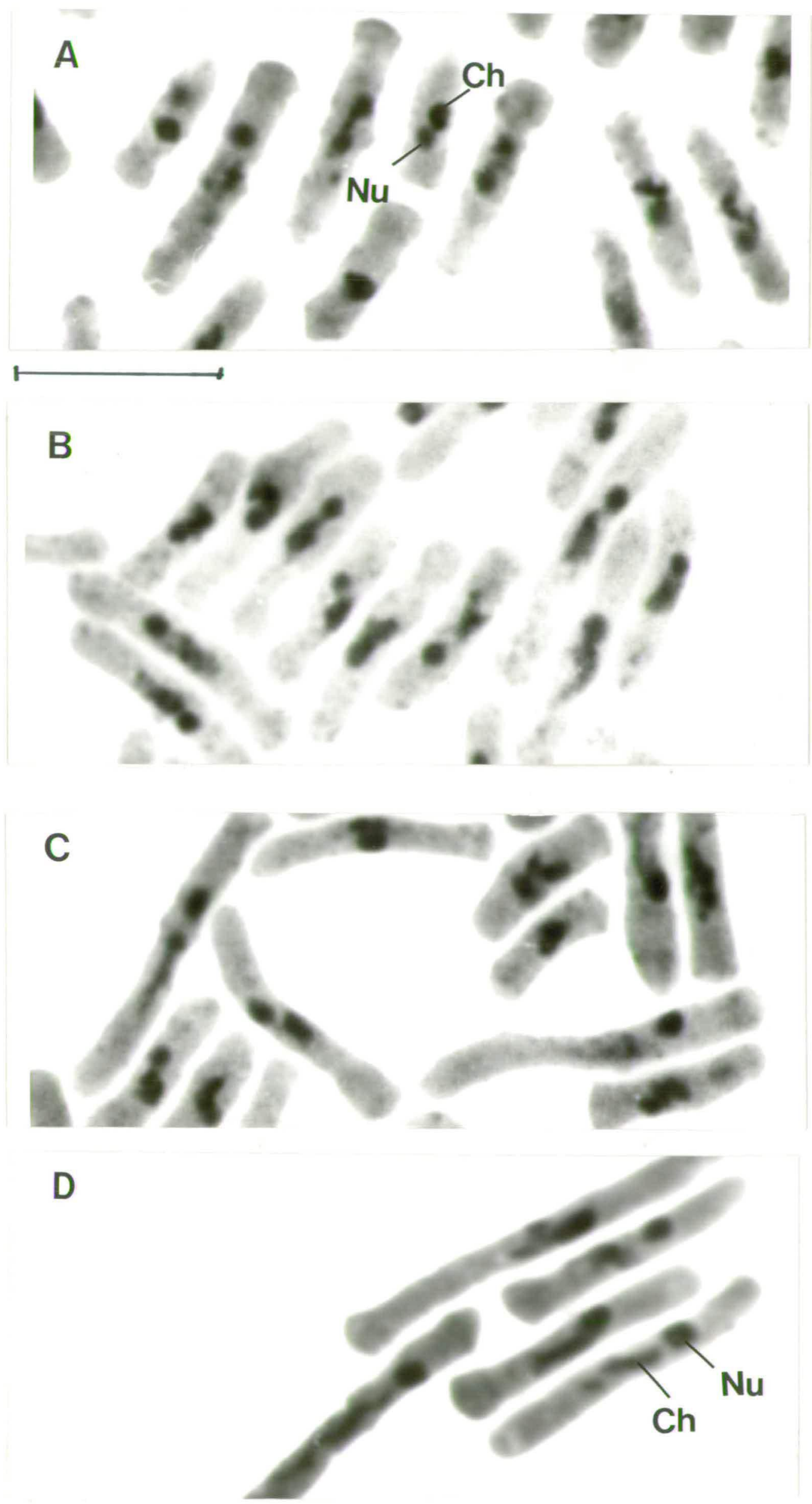

Plate 6.3 Time-course analysis of ben $4 . D 3$ cells following shift to $20^{\circ} \mathrm{C}$. Note relative positions of nucleolus ( $\mathrm{Nu}$ ) and chromatin ( $\mathrm{Ch}$ ).

(a) 2 hours, (b) 5 hours, (c) 7 hours, (d) 10 hours. Bar - $10 \mu \mathrm{m}$. 


\subsection{Acid fuschin staining}

Acid fuschin has been used for the visualisation of yeast nuclei as well as other cellular components, including the mitotic spindle (McCully and Robinow, 1971; Robinow and Marak, 1966).

\section{4 a Cytology of wild type cells}

The nucleus was clearly identified with acid fuschin (Plates $6.4 \mathrm{a}$ and $6.4 \mathrm{~b})$, and in suitably stained preparations discrimination between nucleolar and chromatin regions was possible (Plate $6.4 a$ ). In the interphase nucleus, the lightly staining chromatin region was seen to partially envelope the compact, darkly staining nucleolus (Plate 6.4a). Early stages of mitosis were characterised by the presence of a short intranuclear spindle lying obliquely across the chromatin region (Plate $6.4 \mathrm{a}$ ). Later stages of mitosis involving spindle elongation and separation of daughter nuclei were also recognised (Plate $6.4 \mathrm{~b}$ ). The architecture of the cell wall and details of septum formation were visualised; these structures did not take up the stain and were therefore clearly seen in negative contrast against the more intensely staining cytoplasm.

$6.4 \mathrm{~b}$ Cytology of the terminal phenotype of ben 4 mutants

The morphology of the aberrant nucleus in acid fuschin stained ben $4^{-}$cells was similar to that defined by Giemsa staining. The nucleolus was identified as a compact spherical body, occupying a near terminal position within the cell (Plate $6.4 \mathrm{c}$ ). The elongated and disorganised nature of the chromatin in these cells was seen, though less clearly than in Giemsa stained preparations. In many cells, however, the tenuous attachment of the disorganised chromatin to the nucleolus could be discerned (Plate $6.4 \mathrm{c}$ ). One possibility was that the aberrant nucleus in ben $4^{-}$cells contained an elongated and blocked mitotic spindle. Despite repeated staining attempts, the unambiguous 


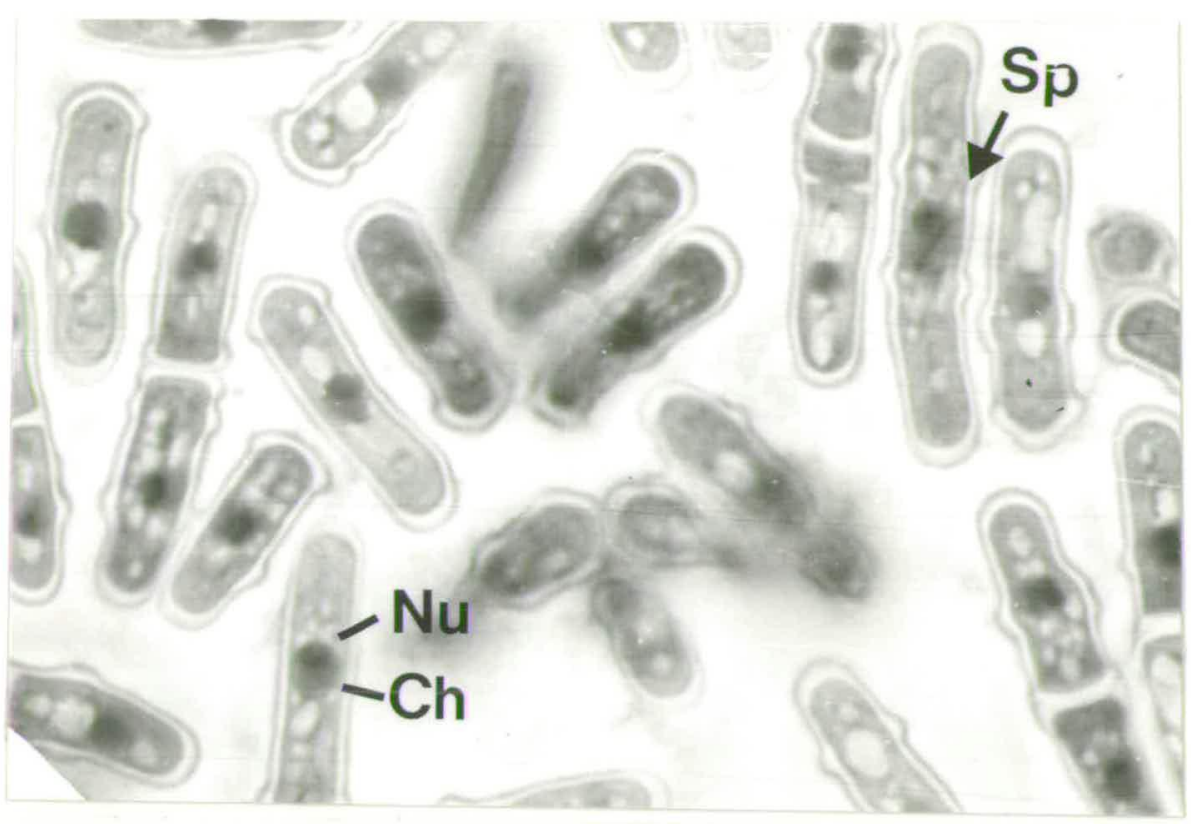

Plate $6.4 \mathrm{a}$ Wild type cells. Acid fuschin staining. Note: Nucleolus (Nu); Chromatin (Ch), and mitotic Spindle (Sp).

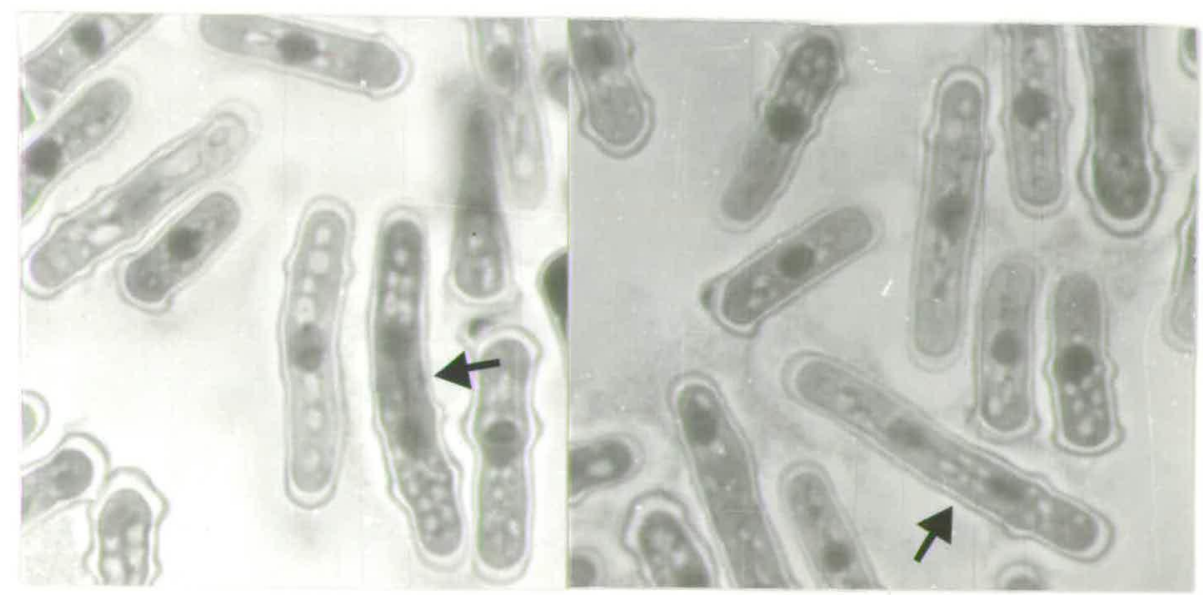

Plate $6.4 \mathrm{~b}$ Wild type cells. Acid Fuschin staining. Note: mitotic Spindle $(\boldsymbol{\Delta})$.

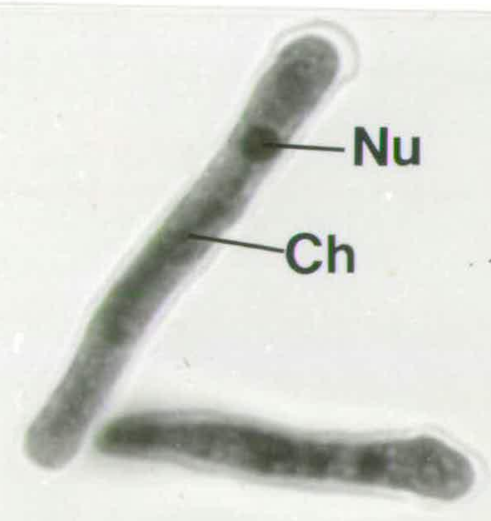

Late $6.4 \mathrm{c}$ Acid fuschin stained preparation of ben4.D3 cells following 10 hours incubation at $20^{\circ} \mathrm{C}$. Note: Nucleolus ( $\mathrm{Nu}$ ) and Chromatin ( $\left.\mathrm{Ch}\right)$. 
identification of such a structure within these cells could not be made.

\subsection{DAPI and ethidium bromide staining}

The compounds 4, 6-diamidine-2-phenyl indolehydrochloride (DAPI) and ethidium bromide have been introduced relatively recently in yeast cytology as fluorescent probes for cellular DNA and RNA respectively. Ethidium bromide binds to double stranded DNA and RNA by intercalation (Bauer and Vinograd, 1968), whereas DAPI complexes preferentially with A-T rich double stranded DNA molecules (Williamson and Fennel, 1975). These probes have a number of advantages for yeast cytology. Firstly, the staining procedure is relatively simple and does not require fixation steps. Secondly, both probes enter the cells rapidly, where they bind tightly and specifically to their cellular targets. Thirdly, a three-dimensional examination of nuclear morphology can be made in cells rotating freely under the cover slip. Finally, it has been reported that DAPI stained $\underline{S}$. pombe cells retain viability for a considerable period of time (Toda et al., 1981). Therefore, it is likely that DAPI stained structures are a true representation of the configuration in vivo.

\section{$6.5 a$ Cytology of wild type cells}

\section{DAPI staining}

DAPI bound selectively to the DNA-rich chromatin part of the nucleus, fluorescing with a bluish-white colouration under U.V. illumination (Plate $6.5 \mathrm{a}$ ). In the interphase nucleus the chromatin region had a roughly hemispherical structure. In addition, two short chromatin protruberances were often observed arising from the planar face of the hemisphere (Plate $6.5 \mathrm{a}$ ). These stub-like processes have been identified previously (Toda et al., 1981; McCully and 


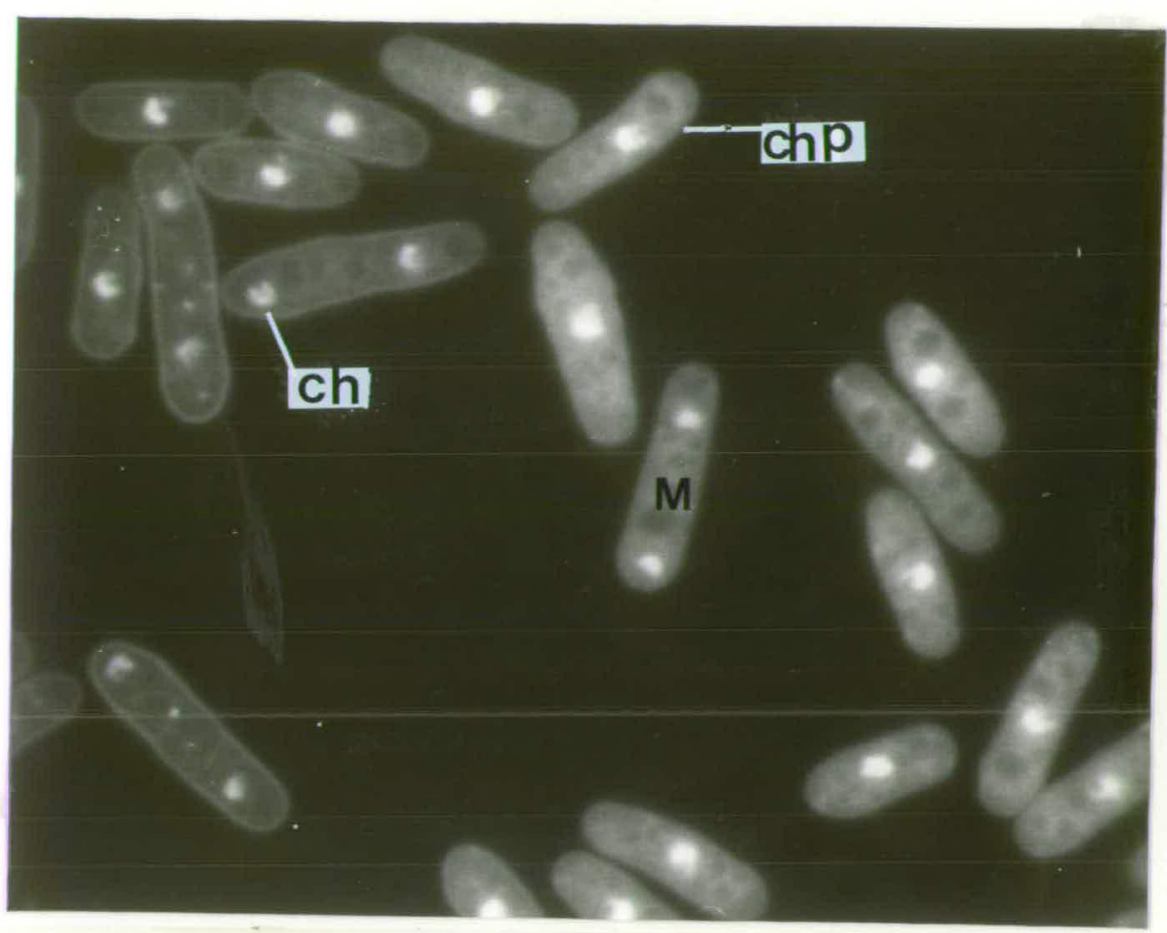

Plate 6.5a Wild type cells. DAPI staining. Note: Chromatin ( Ch); Chromatinic protruberances ( $\mathrm{ChP}$ ) and cells undergoing mitosis (M).

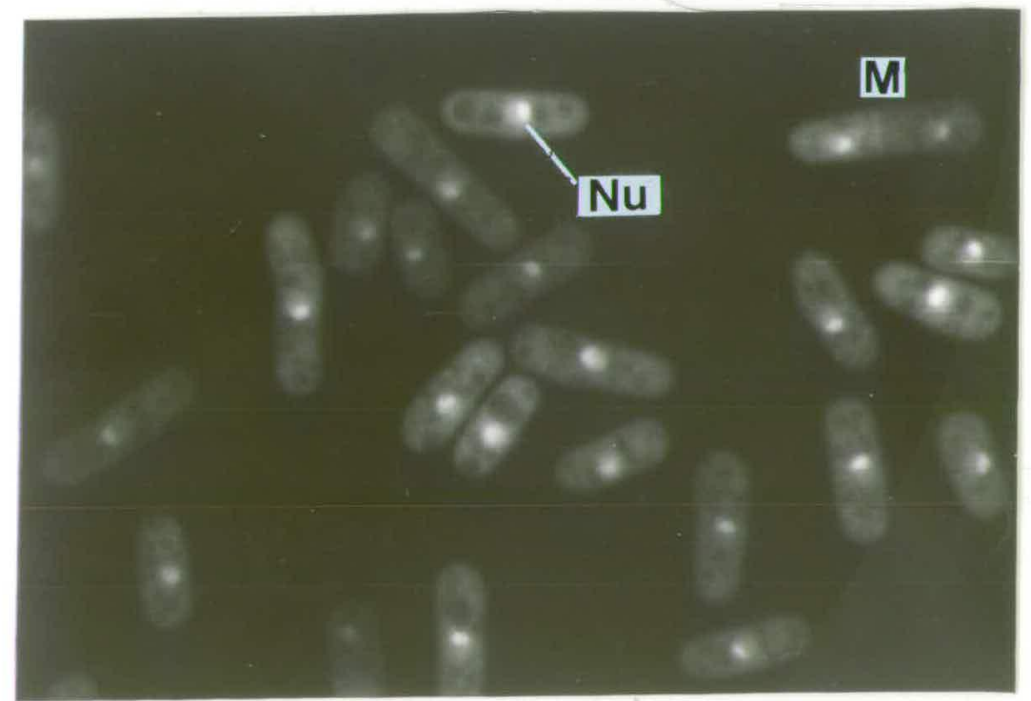

Plate $6.5 \mathrm{~b}$ Wild type cells. Ethidium bromide staining. Note: Nucleolus $(\mathrm{Nu})$ and cells undergoing mitosis (M). 
Robinow, 1971), and are considered by Toda and co-workers (1981)

to represent the protruding ends of one or more condensed chromosomes. Ethidium bromide staining

Ethidium bromide had a strong affinity for the RNA-rich nucleolus, this structure was therefore readily identified from the bright orange fluorescence emitted by bound ethidium bromide under suitable illumination (Plate $6.5 \mathrm{~b}$ ). In the interphase nucleus, the compact nucleolus was found to be closely associated with the planar face of the hemispherical chromatin region (Plate $6.5 \mathrm{~b}$ ). Chromatin and nucleolar regions remained compact and in close association with each other throughout the course of mitosis (Plates $6.5 \mathrm{a}$ and $6.5 \mathrm{~b}$ ). $6.5 b$ Cytology of the terminal phenotype of ben 4 mutants

Cells of the ben 4 mutants under examination were double stained with DAPI and ethidium bromide following prolonged incubation at $20^{\circ} \mathrm{C}$. The nucleolar and chromatin regions within the aberrant nuclei of the same cell were visualised using the appropriate filter combinations (Plates $6.6 a, b, c$ and $d$ ). The nucleolus was identified by ethidium bromide staining as a compact orange-fluorescing body lying, typically, towards one end of the cell (Plates $6.6 \mathrm{a}$ and $6.6 \mathrm{c}$ ). The elongated and disorganised nature of the nuclear chromatin region within these cells was clearly seen with DAPI staining (Plates $6.6 \mathrm{~b}$ and $6.6 \mathrm{~d}$ ); the orientation of the chromatin was similar to that seen in Giemsa and acid fuschin stained preparations. In many cases a thread-like contact of chromatin was maintained between the nucleolus and the bulk of the disorganised chromatin (Plates $6.6 \mathrm{~b}$ and $6.6 \mathrm{~d}$ ). Another noticeable feature of the nucleus in many ben $4^{-}$cells was the presence of two brightly fluorescing dots of DAPI stained material which were found to be closely associated with the nucleolus. These dots may represent the short chromatinic protruberances, described above, which are a 

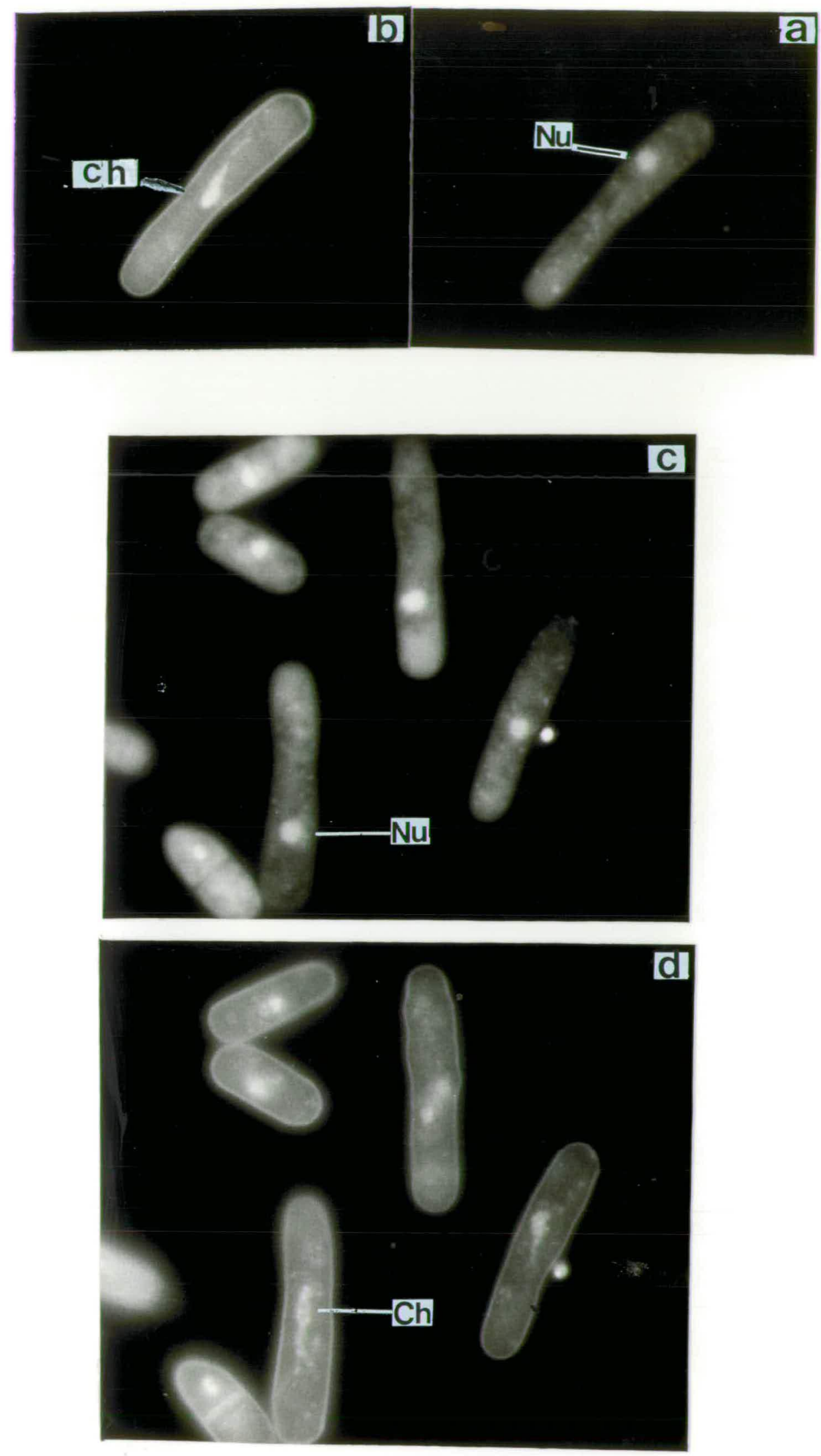

Plates $6.6 \mathrm{a}, \mathrm{b}, \mathrm{c}$ and $\mathrm{d}$ DAPI/Ethidium bromide double staining of ben4.D3 cells following 10 hours incubation at $20^{\circ} \mathrm{C}$. ( $a$ and $c$ ) Ethidium bromide, ( $b$ and $d$ ) DAPI. Note relative positions of nucleolus ( $\mathrm{Nu}$ ) and chromatin ( $\mathrm{Ch}$ ) within the same cell. In some cells the thread-like contact between chromatin and nucleolus can be visualised. 
characteristic feature of the interphase nucleus of wild type cells.

\subsection{Transmission electron microscopy}

Techniques of electron microscopy allow one to confirm and extend at the ultrastructural level, observations made with light microscopy. One persistent caveat is that the harsh nature of the procedures used in the preparation of samples for transmission electron microscopy may induce artifacts which in turn lead to misinterpretations of ultrastructure. Nevertheless, in the yeasts $\underline{S}$. pombe and $\underline{S}$. cerevisiae structures observed at the ultrastructural level correlate well with those seen by light microscopy (McCully and Robinow, 1971; Zickler, 1982; Byers, 1981).

The ultrastructure of wild type and ben 4 cells was examined, following incubation at 35 and $20^{\circ} \mathrm{C}$, using the method of King and Hyams (1982). Briefly, this technique involves glutaraldehyde fixation and enzymatic digestion of the cell wall, followed by further fixation and staining with osmium tetroxide and uranyl acetate. After dehydration, the samples are embedded in low-viscosity resin; material is then thin sectioned and post-stained to afford adequate resolution of ultrastructure at high magnification.

\section{$6.6 \mathrm{a}$ Ultrastructure of wild type cells}

The nucleolar and chromatin regions of the nucleus were well preserved in these preparations (Plate $6.7 \mathrm{a}$ ). In favourable sections through interphase nuclei the spindle pole body (SPB) was found in characteristic location: that is, adpressed to the nuclear membrane and in close association with a mitochondrion (Plate 6.7b). Unfortunately, microtubules were not found in any of the sections examined, whether passing through interphase or mitotic nuclei. Consistent with previous reports (McCully and Robinow, 1971; King and Hyams, 1982), 


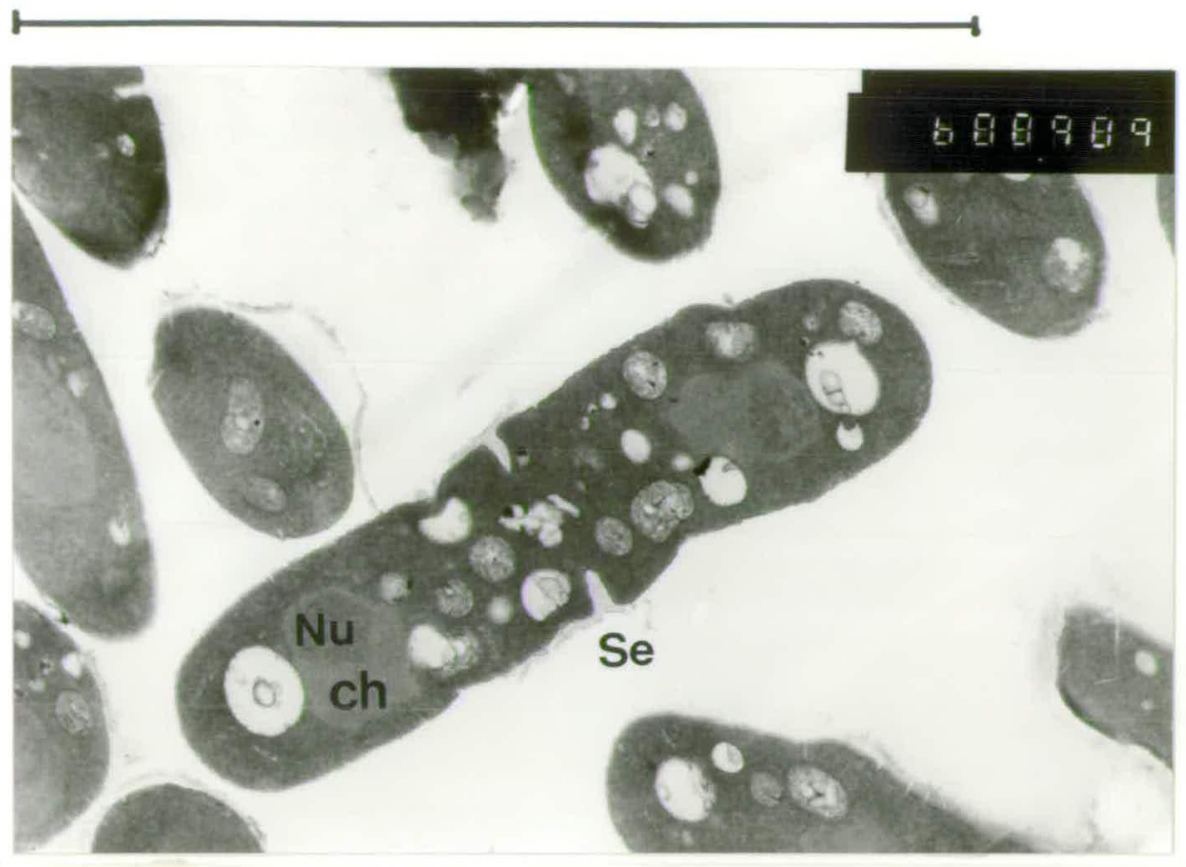

Plate 6.7a Ultrastructure of wild type cells following 10 hours incubation at $20^{\circ} \mathrm{C}$. Note: Nucleolus $(\mathrm{Nu})$, Chromatin $(\mathrm{Ch})$ and initiation of septum formation (Se). Bar - $10 \mu \mathrm{m}$.

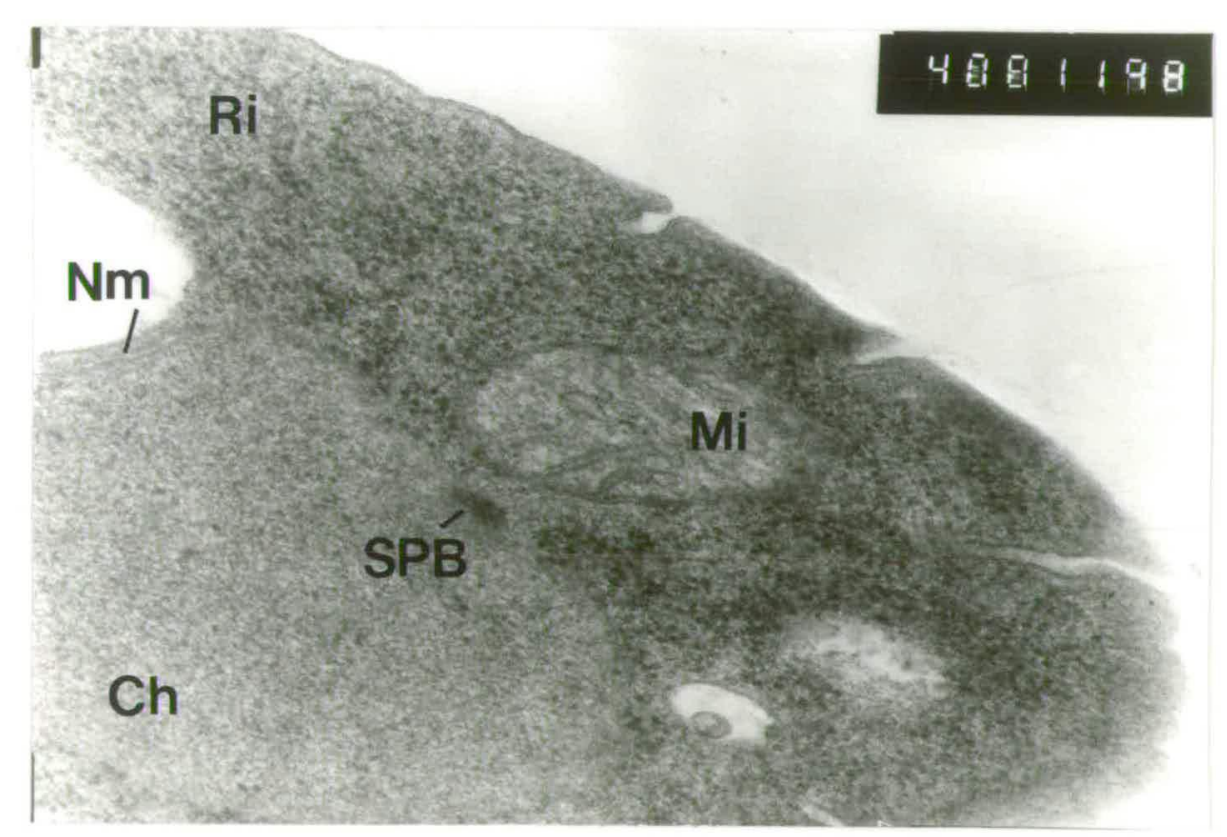

Plate 6.7b Ultrastructure of wild type. Note: Nuclear membrane (Nm), Mitochondrion (Mi), Chromatin ( $\mathrm{Ch}$ ), Ribosomes (Ri) and Spindle pole body $(\mathrm{SPB})$. 


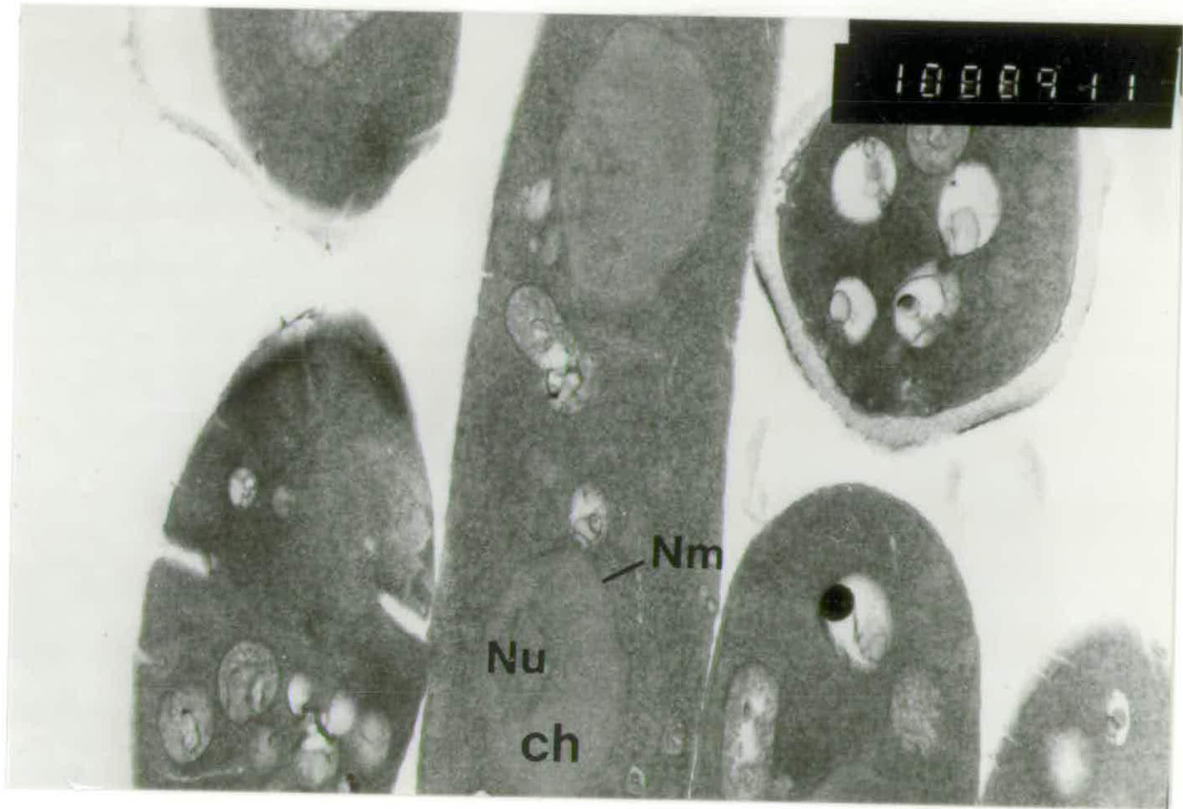

Plate 6.7c Ultrastructure of wild type cells undergoing mitosis. Note: Chromatin ( $\mathrm{Ch})$, Nucleolus $(\mathrm{Nu})$ and location of nuclear membrane $(\mathrm{Nm})$. 
the nuclear membrane appeared to remain intact throughout mitosis (Plate $6.7 \mathrm{c}$ ). Mitochondria and other membrane bound organelles were adequately preserved in these preparations, and observations made at high magnification showed the cytoplasm to be densely packed with ribosomes (Plate $6.7 \mathrm{~b}$ ).

$6.6 \mathrm{~b}$ Terminal phenotype of $\underline{\text { ben } 4}$ mutants

The ultrastructure of ben $4^{-}$cells was examined following ten hours incubation at $20^{\circ} \mathrm{C}$. The morphology of the single nucleus in these cells was very different from that seen in wild type cells. In particular, the chromatin region was found to be elongated and frequently disorganised within the cell (Plates $6.8 \mathrm{a}, \mathrm{b}, \mathrm{c}$ and d); however, the extent of chromatin elongation observed in nuclear profiles was dependent upon the plane of sectioning. It was clear that the chromatin remained attached to the eccentrically placed nucleolus. Typically, the chromatin ran from its point of attachment to the nucleolus towards the opposite end of the cell (Plates $6.8 \mathrm{a}, \mathrm{b}$ and c). The nuclear membrane appeared to remain intact despite the aberrant form of the nucleus (Plate $6.8 \mathrm{e}$ ). In suitable sections it was possible to analyse SPB morphology and location. From this study it was concluded that ben 4 cells arrest with a single SPB, located in the nuclear membrane close to the nucleolus (Plate $6.8 \mathrm{e}$ ). It was not always possible to relate SPB location to the position of the nucleolus; for example, the nuclear profile presented in Plate $6.8 \mathrm{~d}$ shows the SPB to be preferentially associated with the disorganised chromatin.

Intranuclear microtubules were not identified in any of the sections examined. However, microtubule-like structures were visible in the cytoplasm of one arrested ben4.D3 cell (Plate $6.8 \mathrm{e}$ ). These elements were closely associated with the SPB and had an approximately 

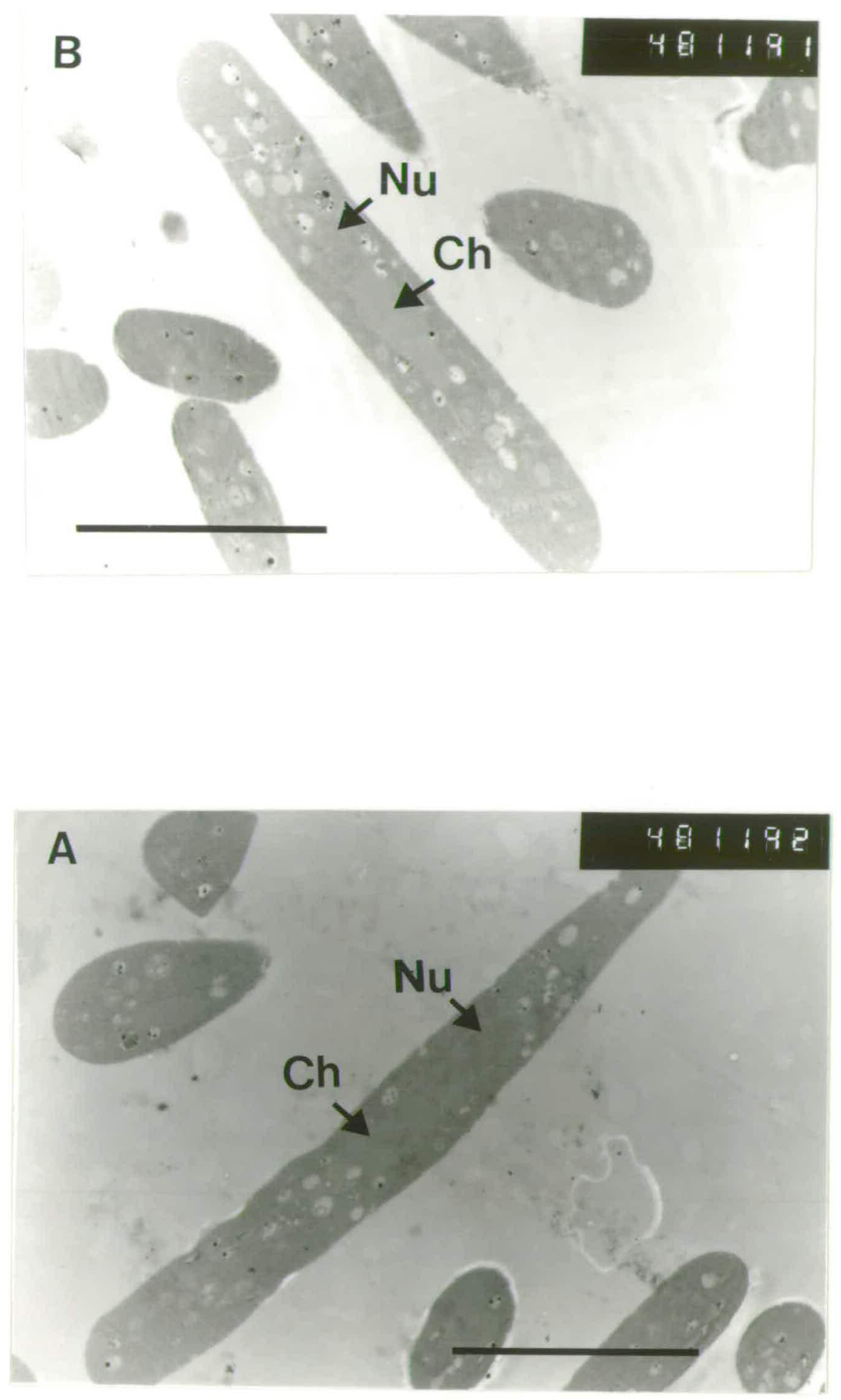

Plates $6.8 \mathrm{a}$ and $6.8 \mathrm{~b}$ Ultrastructure of ben $4 . D 3$ cells following 10 hours incubation at $20^{\circ} \mathrm{C}$. Note: Nucleolus ( Nu) and Chromatin ( Ch). (a) Bar - $3.75 \mu \mathrm{m}$, (b) Bar - $4.7 \mu \mathrm{m}$. 


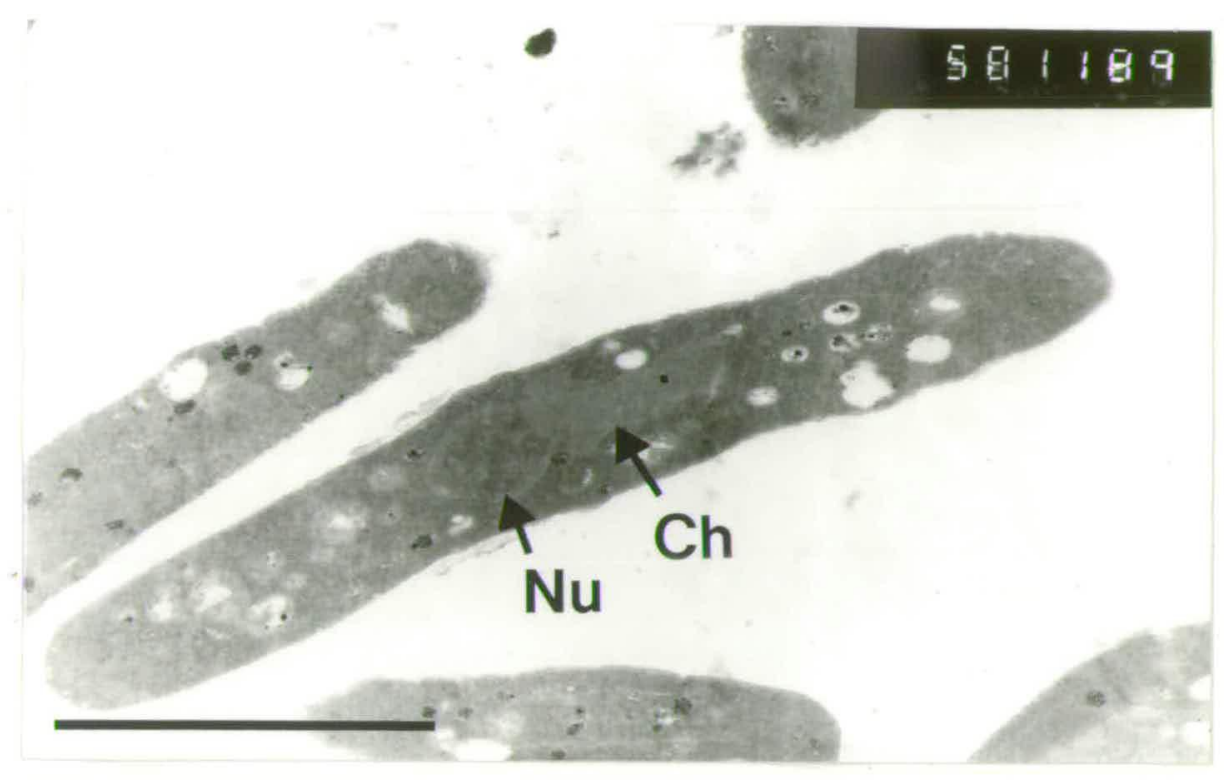

Plate $6.8 \mathrm{c}$ Ultrastructure of ben4.D3 cells following 10 hours incubation at $20^{\circ} \mathrm{C}$. Note: Nucleolus $(\mathrm{Nu})$ and Chromatin $(\mathrm{Ch})$. Bar $-4.5 \mu \mathrm{m}$.

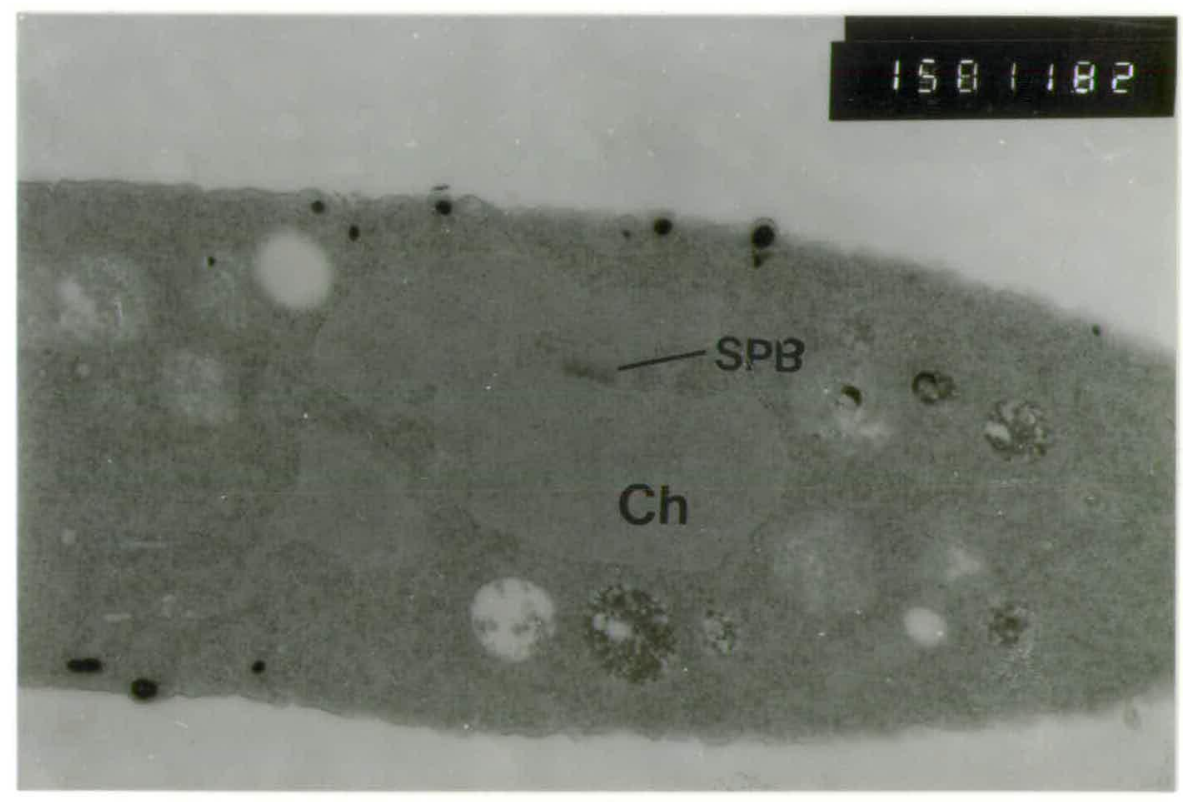

Plate 6.8d Ultrastructure of ben4.D3 cells following 10 hours incubation at $20^{\circ} \mathrm{C}$. Note: Spindle pole body (SPB) and disorganised nature of chromatin ( $\mathrm{Ch}$ ). 


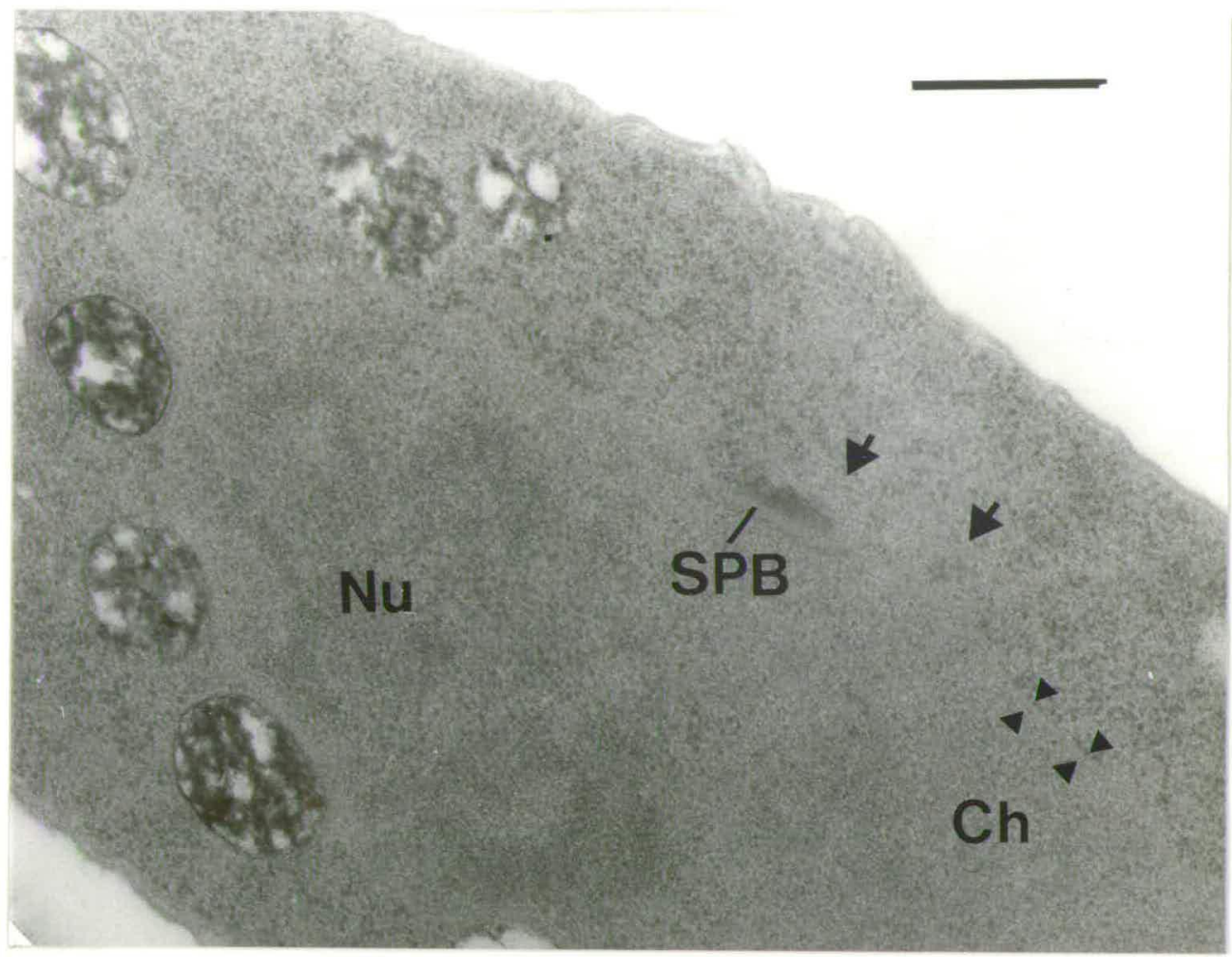

Plate $6.8 \mathrm{e}$ Ultrastructure of ben $4 . D 3$ cells following 10 hours incubation at $20^{\circ} \mathrm{C}$. Note: Chromatin ( $\mathrm{Ch}$ ), Nucleolus (Nu), Spindle pole body (SPB), microtubule-like elements (large arrows) and location of the nuclear membrane (small arrows). Bar $-0.5 \mu \mathrm{m}$. 
longitudinal orientation within the cell. Since this study failed to identify nuclear microtubules at the ultrastructural level, an alternative approach, that of immunofluorescence microscopy was used in an attempt to analyse the distribution of microtubules in wild type and ben $4^{-}$cells.

\subsection{Attempted identification of microtubules in $\underline{S}$. pombe with}

immunofluorescence microscopy

A monoclonal antibody, YOL/34, which recognises tubulin from budding yeast has recently been identified (Kilmartin, Wright and Milstein, 1982). This antibody has been extensively used for the detection of microtubules in Saccharomyces cerevisiae and Saccharomyces uvarum via indirect immunofluorescent microscopy (Kilmartin and Adams, 1984; Adams and Pringle, 1984). This technique involves several steps. The cell wall is first removed enzymatically and the resulting sphaeroplasts are fixed and permeabilized in order to facilitate binding of the primary antibody (YOL/34) to tubulin sites. A second antibody, which is coupled to a fluorochrome such as FITC, is then added as a probe for the location of tubulin bound YOL/34 antibody. The location of the primary-secondary antibody complex is visualised from FITC fluorescence emitted under the appropriate illumination.

A preliminary attempt was made to detect microtubules in cells of a diploid strain (S41) of $\underline{S}$. cerevisiae using this approach. Successful staining of the microtubule system in these cells was obtained. The mitotic apparatus was identified, and stages of spindle elongation during mitosis were seen (Plates $6.9 \mathrm{a}$ and $6.9 \mathrm{~b}$ ). The single fluorescent dot present in a proportion of the cells most probably represents the location of the single spindle pole body 

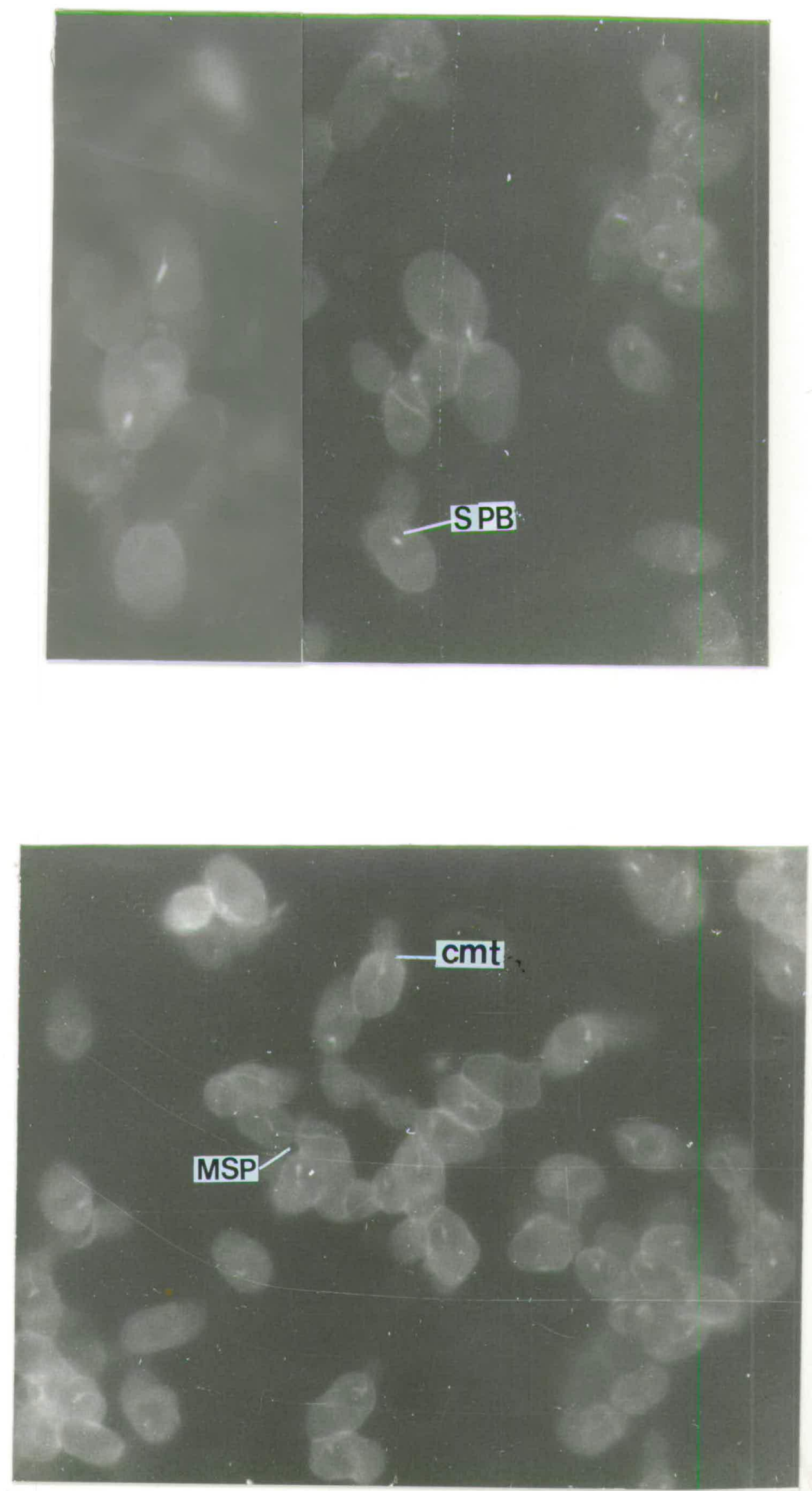

Plates $6.9 \mathrm{a}$ and $6.9 \mathrm{~b}$ Detection of microtubules in $\underline{S}$. cerevisiae strain $\mathrm{S} 41$. Note: Mitotic spindles (MSp), cytoplasmic microtubules (CMt) and Spindle pole bodies (SPB). 
present in interphase cells. Occasionally, cytoplasmic microtubules were faintly seen arising from this structure and were usually orientated towards the site of the developing bud (Plates $6.9 a$ and $6.9 b)$. It was found that removal of the cell wall either before or after fixation made little difference to the images of microtubules obtained.

Disappointingly, neither microtubules nor spindle pole bodies were visualised in wild type $\underline{\mathbf{S}}$. pombe cells using this approach. This was in spite of repeated staining attempts, involving fixation either before or after removal of the cell wall. Attempts to detect microtubules in ben $4^{-}$cells were therefore not carried out. Several reasons may be proposed for the failure to detect microtubules in $\underline{S}$. pombe with this technique. Firstly, the structure of microtubules and SPBs may not have been adequately preserved under the experimental conditions used. Secondly, the primary antibody may have been physically impaired from reaching tubulin sites, due possibly to membrane or nuclear matrix barriers. The third possibility is that the antigenic determinants recognised by $Y O L / 34$ are not present in S. pombe. 
From these studies a clear cytological description of the terminal phenotype exhibited by several of the strongly cold sensitive ben 4 mutants was obtained. From the preliminary cytological observations carried out previously (section 5.2c), it would seem likely that the remaining mutants of this group (C23 and ben4.D2, D3, $A 22(I), C 29(I), D 19(I)$ and $D 23(I))$ exhibit a very similar terminal phenotype to those mutants analysed in detail above. The aberrant nature of the nucleus seen in ben $4^{-}$cells was consistent with the hypothesis that the ben $4^{+}$gene product plays an important role in the mitotic apparatus. Possible mechanisms to account for the formation of the aberrant nucleus in these cells are discussed in Chapter 8.

\subsection{Cytological analysis of hsR5 cells}

Preliminary cytological observations (section $5.4 \mathrm{c}$ ) indicated that the heat sensitive mitotic mutant hsR5 expressed a complex terminal phenotype at the restrictive temperature. In this section the formation of this complex phenotype, as revealed by Giemsa staining, is described.

During the first four hours following shift up hsR5 cells arrested with a single nucleus (not shown) which was indistinguishable in morphology from that seen in the normal interphase cell. After this time condensation of the nuclear material occurred, and within six hours approximately $75 \%$ of hs $^{-} 5^{-}$cells contained a number of discrete chromatinic bodies (Plate $6.10 a$ ). These structures were reminiscent of the condensed chromosomes which appear during meiosis in $\underline{S}$. pombe (Robinow, 1977) and which have been induced in vegetative cells of this organism under certain experimental conditions (Umesono et al., 1983b; Nasmyth and Nurse, 1981). In some hsR5- cells three discrete chromatinic bodies were observed (Plate 6.10a), a figure 

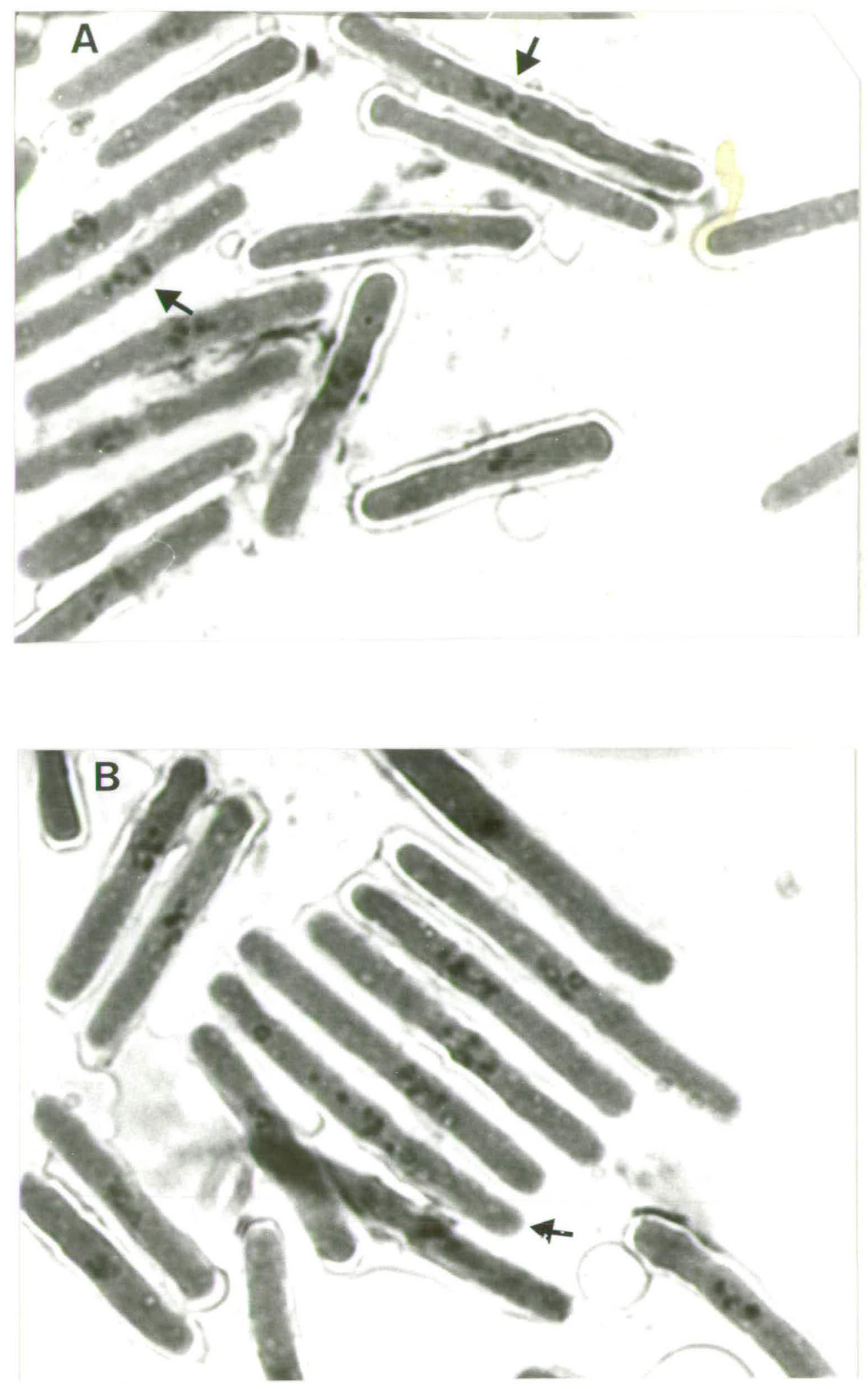

Plates $6.10 \mathrm{a}$ and $6.10 \mathrm{~b}$ Chromosome condensation in $\mathrm{hsR}^{-}$cells following 6 hours incubation at $35^{\circ} \mathrm{C}$.

(a) Condensed chromosomes are present in the majority of cells. Arrowed cells appear to contain three chromosomes.

(b) Condensed chromosomes are present in the majority of cells. Notice scattered location of condensed bodies within the arrowed cell. 
identical to the normal haploid chromosome complement of this organism (Robinow, 1977; Kohli et al., 1977). From these observations it was considered that the chromatinic bodies in $\mathrm{hsR}^{-}$cells indeed represented condensed chromosomes. In the majority of $\underline{\mathrm{hs}} \mathrm{R}^{-}$cells the condensed chromosome-like bodies were clustered together towards the geometric centre of the cell. In rare instances, however, up to six chromosome-like bodies were found scattered throughout the cell (Plate $6.10 \mathrm{~b})$. This observation was of interest and may indicate that separation and partial segregation of sister chromatids had taken place.

Around five hours post-shift the fraction of cells containing a single transverse septum began to increase, and with prolonged (sixteen hours) incubation at $35^{\circ} \mathrm{C}$ approximately $80 \%$ of cells were septated. Two classes of septated cells were observed seven hours from shift up (Figure 5.9). One class (Type X) contained a single nucleus, located in one of the two cytoplasmic compartments formed by the septum (Plate $6 \cdot 10 \mathrm{c}$ ). The second (Type Y cells) contained two distinct but closely associated nuclei, both of which were located within a single cytoplasmic compartment (Plate $6.10 \mathrm{~d}$ ). It may be that the two nuclei in Type $Y$ cells represent daughters which have become blocked in segregation following separation. The condensed chromosomelike bodies described above were not seen in either Type $\mathrm{X}$ or Type $\mathrm{Y}$ cells. Instead, the nuclear material in these cells assumed a compact form, a configuration more reminiscent of the normal interphase nucleus (Plate $6.10 \mathrm{c}$ and $6.10 \mathrm{~d}$ ). It was concluded that Type $\mathrm{Y}$ cells represented the terminal phenotype of this mutant. However, although the majority of hsR5 cells became septated after prolonged incubation at $35^{\circ} \mathrm{C}$, the proportion of Type $\mathrm{X}$ and Type $\mathrm{Y}$ cells under these conditions was not ascertained. 

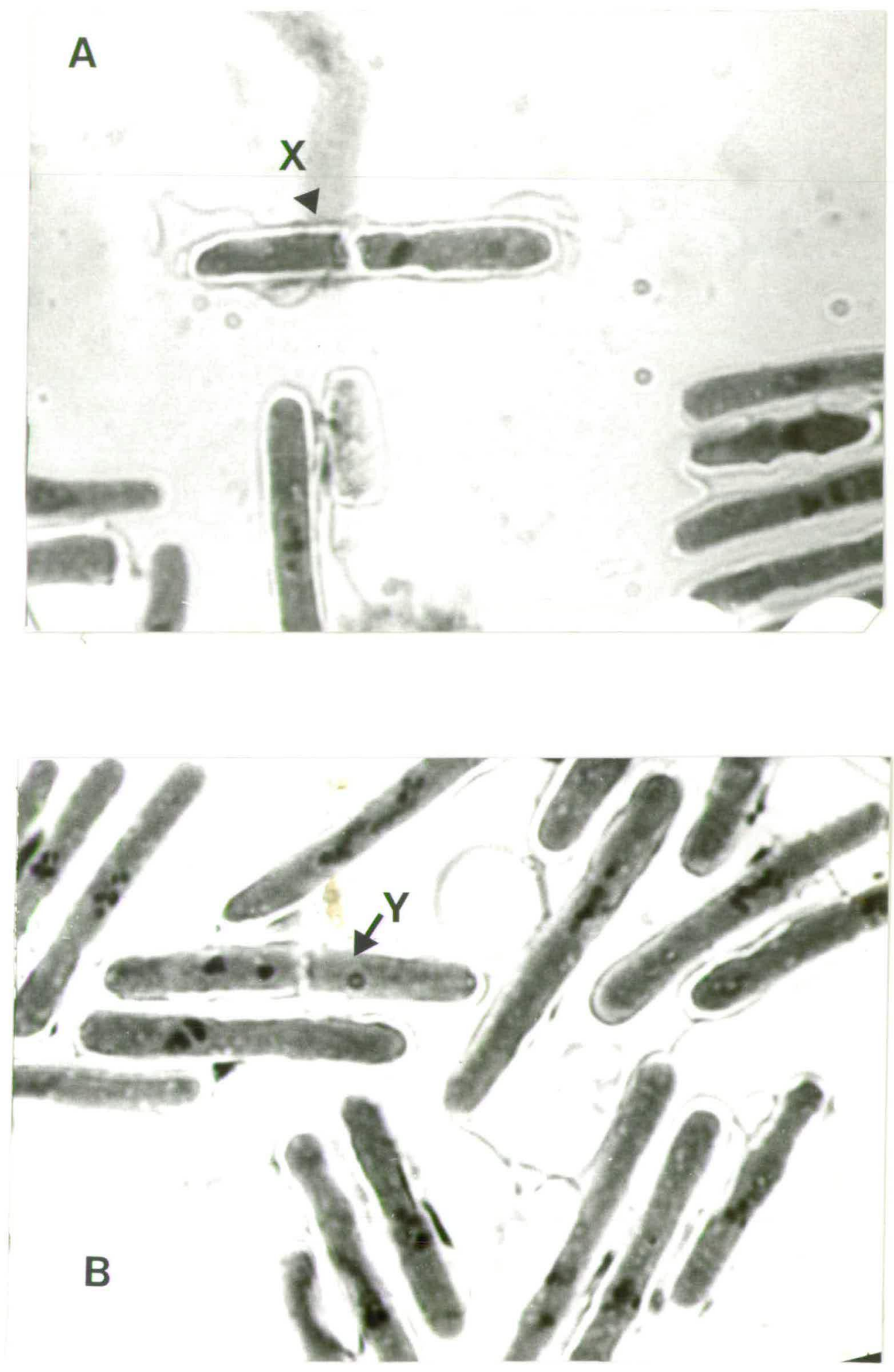

Plates $6.10 \mathrm{c}$ and $6.10 \mathrm{~d}$ Phenotype of Type X and Type Y hsR5 cells.

(a) Type X cell (arrowed). Note: septum, single nucleus and anucleate

(b) Type Y cell (arrowed). Note: septum, two nuclei within one compartment, and anucleate compartment. 
Two alternative models may be proposed for the formation of Type $Y$ cells. In the first model (model A; Figure 6.1), Type Y cells arise from the partioning of a binucleated cell by septation in a way that traps the two nuclei into a single cytoplasmic compartment. In the second model (model B; Figure 6.1) septum formation takes place in a uninucleated cell before the onset of mitosis, localising the single nucleus into one compartment. Subsequent separation of daughter nuclei results in the formation of Type Y cells. It should be noted that both models probably require 'decondensation' of nuclear material as well as nuclear displacement to occur prior to septation (Figure 6.1).

From the available data, it would appear that model B correctly interprets the formation of Type $Y$ cells. Three lines of evidence support this hypothesis. Firstly, seven hours from shift up the frequency of Type $\mathrm{X}$ cells is three times greater than the frequency of Type $Y$ cells (section 5.4c), thereby generating an excess of intermediate forms (Type $X$ cells) required for model B. Secondly, at the seven hour time point, no intermediate stages (binucleated but nonseptated cells; see Figure 6.1, model A) as proposed for model A were seen. Thirdly, the partioning of daughter nuclei into a single compartment, as proposed in model A, would necessitate an extensive assymetrical distribution of both daughter nuclei towards one end of the cell. However, model A cannot be excluded definitively, and it may be that Type $Y$ cells arise by either of the pathways described.

As discussed in Chapter 1, studies with certain cde mutants have shown that septum formation is normally dependent upon the prior completion of mitosis in $\underline{S}$. pombe, and that in the normal situation a septum is laid down only between fully separated daughter nuclei (McCully and Robinow, 1971). Type $X$ and Type $Y$ cells both contain a 


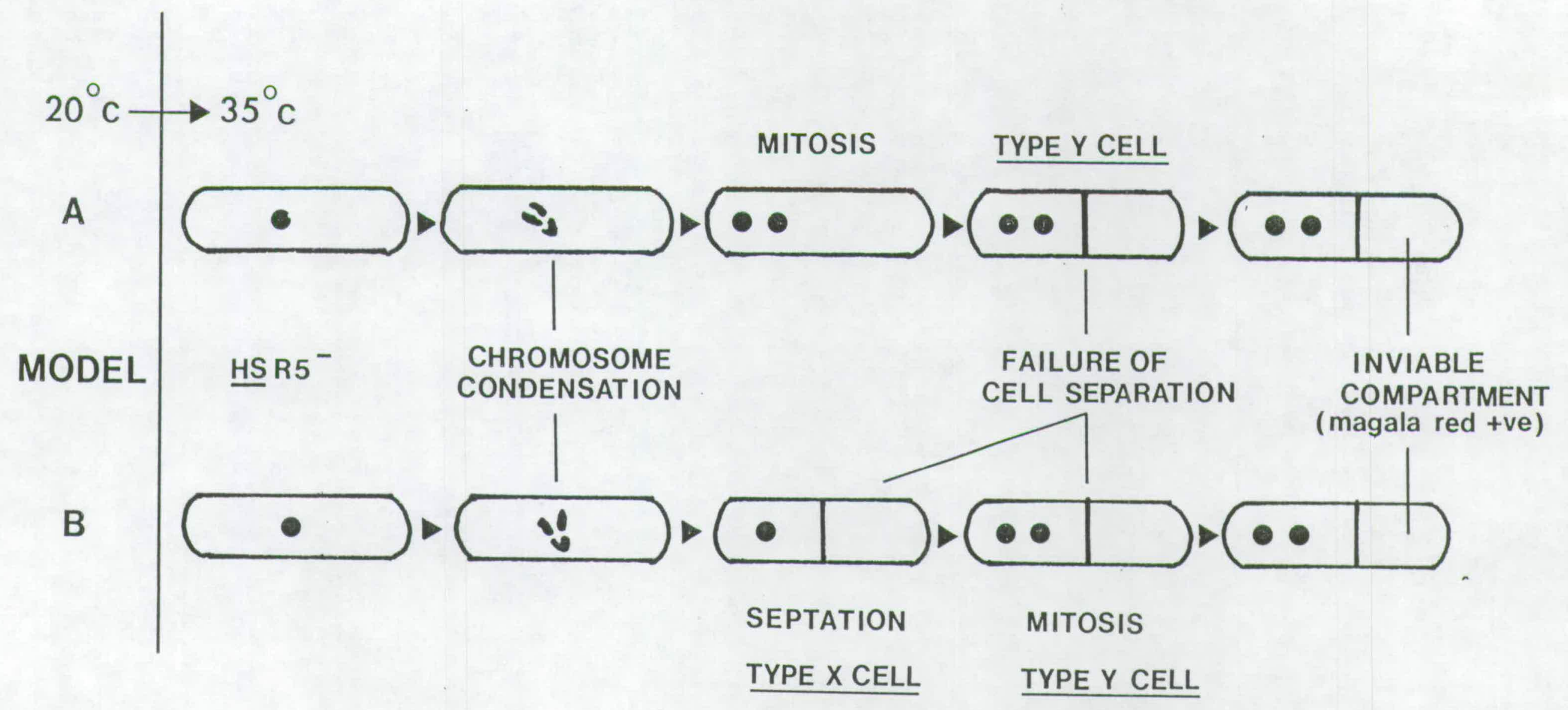

Figure 6.1 Two alternative models proposed for the formation of type $\mathrm{Y}$ cells of mutant hsR5. 
single anucleate compartment; a phenotype which reveals a breakdown in the normal temporal and/or positional control which ensures the correct integration of septation with mitosis. Almost certainly, the anucleate compartment in Type $X$ and Type $Y$ cells rapidly becomes inviable in the absence of substantial cytoplasmic contact with the neighbouring, nucleated, compartment.

\subsection{Cytological analysis of ben 4 cdc double mutants}

Previous observations (section $4.11 \mathrm{~b}$ revealed that double mutants of the form ben4.D19 cdc or ben4.D23 cdc exhibited a curious and dramatic curvature in cell morphology when incubated at $35^{\circ} \mathrm{C}$ (Plate 6.11a). In extreme examples of this phenotype, the opposite ends of the cell were virtually in contact (Plate 6.11a). A less frequent observation was the occurrence of cells with an S-shaped morphology (Plate $6.11 \mathrm{~b})$. The occurrence of the 'curly' phenotype was restricted to those ben 4 cdc double mutants which carried ben 4 alleles conferring a strong cold sensitive cde phenotype. The 'curly' phenotype was considered to be a consequence of the slight curvature in cell morphology exhibited by this group of ben 4 mutants at the permissive temperature (section $5.2 \mathrm{a}$ ). The curvature in cell morphology conferred by the ben 4 mutation would become more pronounced in ben 4 cdc double mutants at $35^{\circ} \mathrm{C}$, since growth continues in such cells despite the division block imposed by the heat sensitive lesion. One intriguing speculation was that the curvature in cell morphology conferred by the ben 4 mutation, and so clearly seen in ben 4 cde double mutants, was the result of a specific defect in a cellular mechanism which normally maintains the correct orientation of tip growth in this organism. Interestingly, those ben 4 cdc double mutants which exhibited a 'curly' morphology at $35^{\circ} \mathrm{C}$ did not express this phenotype at $20^{\circ} \mathrm{C}$. 

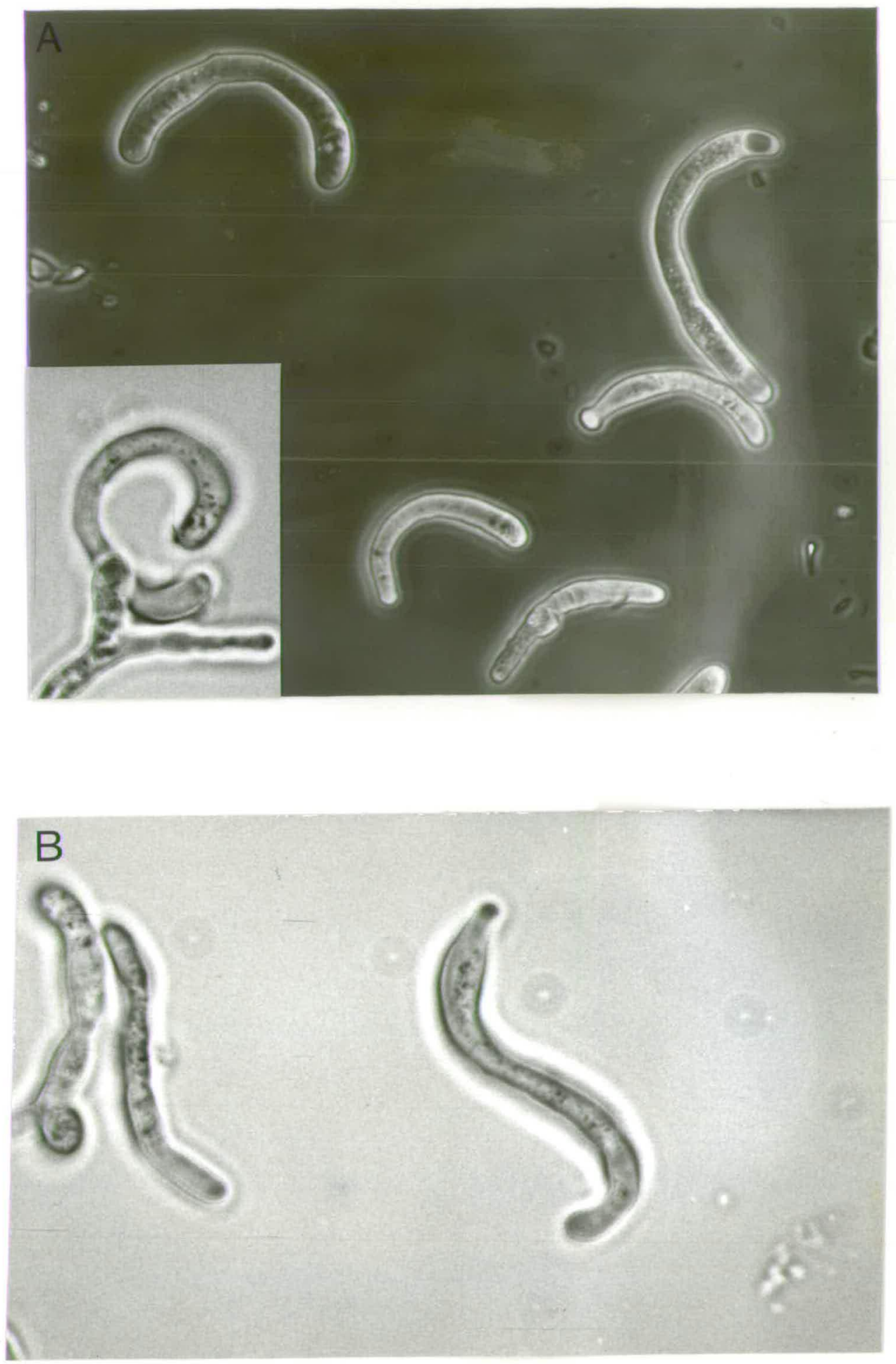

Plates $6.11 \mathrm{a}$ and $6.11 \mathrm{~b}$ Morphology of ben4.D3 cde27.K3 double mutants: following 16 hours incubation at $35^{\circ} \mathrm{C}$.

(a) Examples of 'curly' phenotype.

(b) Examples of ' $S$ ' shaped phenotype. 
Under these latter conditions, the mutants exhibited an elongated cylindrical morphology typical of that conferred by the ben 4 mutation alone. In contrast, double mutants of the form ben $4 . \mathrm{C} 10$ cde expressed an elongated cylindrical morphology when incubated at either 35 or $20^{\circ} \mathrm{C}$. 


\section{Chapter 7}

AN APPROACH TOWARDS THE IDENTIFICATION OF THE ben $4^{+}$

GENE PRODUCT

\section{1 Introduction}

The phenotypic properties exhibited by the ben 4 mutants examined thus far provided strong evidence that the ben $4^{+}$gene product was directly associated with the mechanism of mitosis. The working hypothesis used throughout the experimental work was that the ben $4^{+}$gene coded for a $\beta$-tubulin protein. A molecular genetic approach was subsequently initiated in an attempt to test this hypothesis directly.

With the advent of recombinant DNA technology the physical isolation of yeast genes has become an area of intense research activity. At the cornerstone of this research has been the development of transformation systems for the well studied yeasts $\underline{s}$. cere$\underline{\text { visiae }}$ and $\underline{S}$. pombe. Plasmid vectors capable of replication in either yeast or bacterial (E. coli) hosts have been developed. In the construction of such vectors the following three components are generally included: (1) elements which permit the replication of the plasmid in either host; (2) suitable genetic markers which allow for selection of the plasmid in either host; and (3) various unique. cloning sites, defined by different restriction enzyme sites located within the selectable genetic markers. The insertion of foreign DNA fragments at these sites is selected for, most usually, by insertional inactivation of the specific marker.

Recently, Neff et al. (1983) have described the isolation and characterisation of the $\beta$-tubulin gene from $\underline{S}$. cerevisiae. The yeast $\beta$-tubulin gene was originally detected as showing homology to a chick cDNA $\beta$-tubulin probe. The selected yeast sequence was found to 
complement the benomyl resistance and cold sensitive phenotypes conferred by a mutation in the TUB2 gene of $\underline{S}$. cerevisiae. These workers found that the cloned fragment directed integration of a plasmid carrying this fragment specifically to the TUB2 locus. This result confirmed the cloned yeast fragment to be the TUB2 gene. When analysed, the TUB2 gene showed approximately $70 \%$ sequence homology to the chick $\beta$-tubulin gene. The TUB2 gene therefore codes for a $\beta$-tubulin protein in this organism.

The availability of a $\beta$-tubulin gene from budding yeast presented an opportunity to test directly the proposal that the ben $4^{+}$gene of $\underline{\mathrm{S}}$. pombe encodes a $\beta$-tubulin. In this respect, the ability of the S. cerevisiae $\beta$-tubulin sequence to transform ben $4^{-}$cells to a ben $4^{+}$phenotype was tested.

Plasmid PRB129

A plasmid, designated pRB129, containing the entire coding region of the $\underline{\underline{S}}$. cerevisiae $\beta$-tubulin (TUB2) gene was obtained from Dr. M. Thomas (MIT, Cambridge, Mass., USA). A diagram of this plasmid is given in Figure 7.1. The bacterial sequences in pRB129 are derived from pBR322, and a $4.1 \mathrm{~kb}$ DNA fragment containing the entire $\underline{S}$. cerevisiae $\beta$-tubulin coding region is inserted into the unique $\underline{B a m H} 1$ site of the tetracycline resistance $\left(\mathrm{Tc}^{r}\right)$ gene. Large scale preparations of pRB129 were made from transformed $\underline{E}$. coli cells grown under selection for ampicillin resistance. Dye buoyant centrifugation in caesium chloride gradients was performed on the crude nucleic acid preparation to obtain plasmid in pure form (Sections $2.6 \mathrm{~d}$ and 2.6e). This preparation of pRB129 was found to transform competent cells of $\underline{\mathrm{E}}$. coli (strain JA221) to ampicillin resistance at a frequency of $5-8 \times 10^{5}$ transformants per $\mu \mathrm{g}$ of plasmid DNA. Digestions of pRB129 with each of the restriction enzymes BamHI 


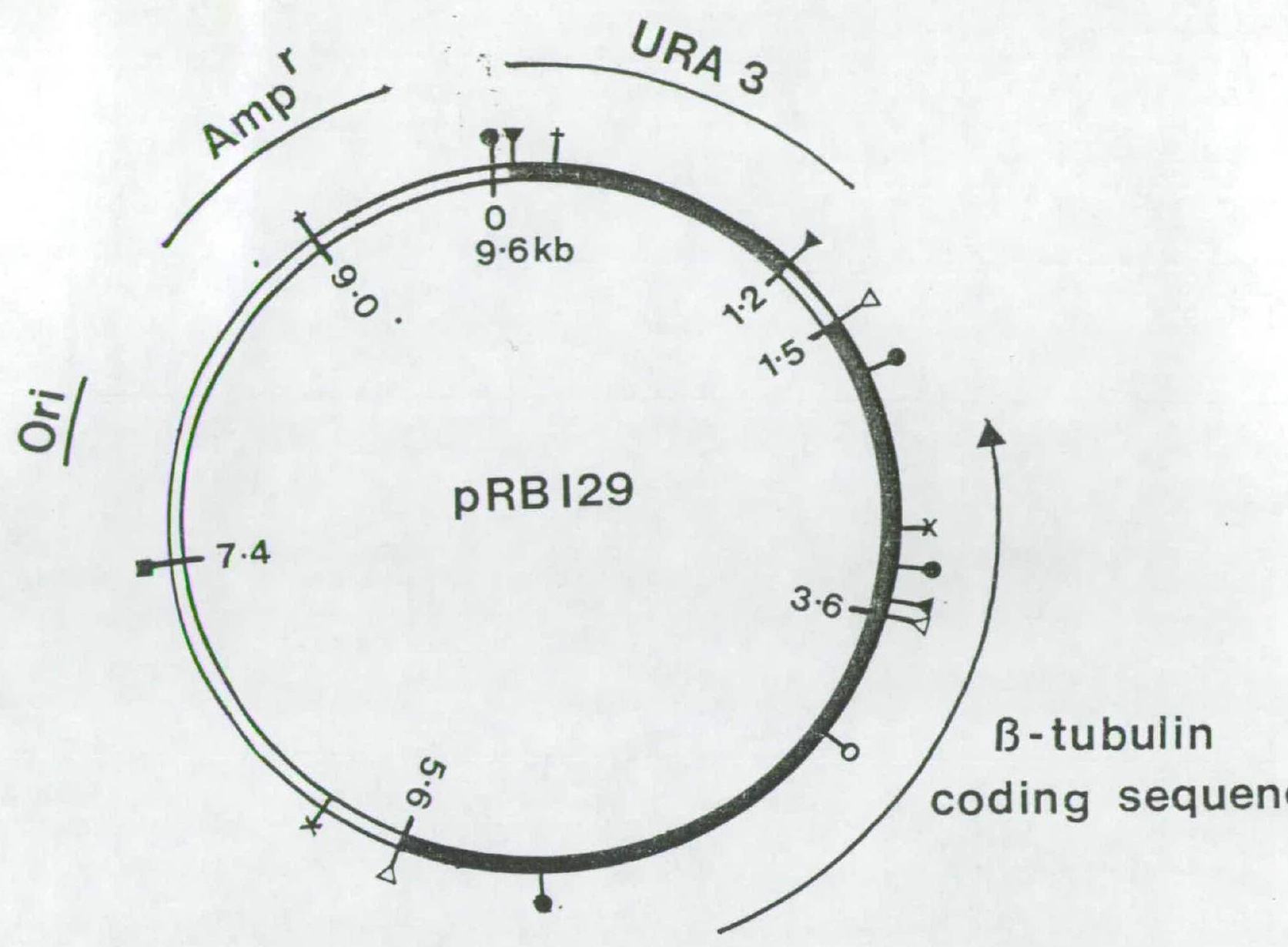

Symbols

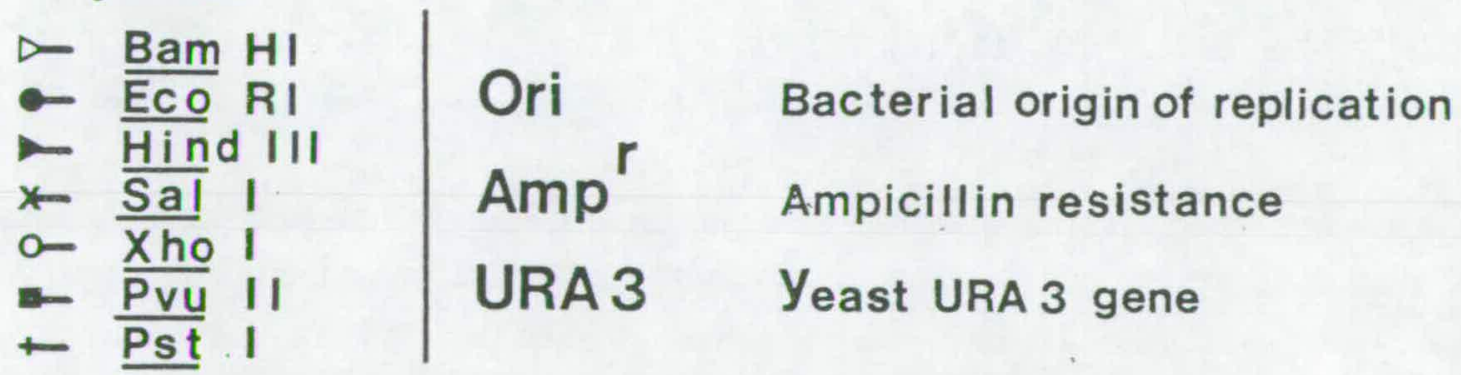

Figure 7.1 Diagramatic representation of pRB129 (scale approximate). 
( 3 cleavage sites); XhoI (single site) and PstI (single site) were performed. When analysed by agarose gel electrophoresis (data not shown), the pattern of restriction fragments generated from these digests was in agreement with the structure given in Figure 7.1.

7.2 Attempted complementation of the ben 4 mutant phenotype with plasmid pRB129

Plasmid pRB129 does not contain elements which permit the autonomous replication of the plasmid in budding yeast. As such, pRB129 is classified as an integrating vector. That is, the plasmid will only be maintained in $\underline{S}$. cerevisiae following integration into the genome. The integration event is brought about by the homologous recombination of the plasmid at either the URA3 or the TUB2 locus. It was considered possible that pRB129 might integrate into the $\underline{S}$. pombe genome due to recombination at homologous $\beta$-tubulin sequences. Since the URA3 gene of $\underline{S}$. cerevisiae has been shown to complement the ura 4.294 mutation of $\underline{s}$. pombe (Losson and Lacroute, 1983), it was considered that the integration of pRB129 into the genome of ben $4^{-}$ura $4^{-}$mutants of $\underline{\mathrm{S}}$. pombe might be detected by selecting for $\underline{u r a}^{+}$transformants. Any ${\underline{\text { ra }^{+}}}^{+}$transformants obtained would then be screened for the effect of the integrated $\underline{s}$. cerevisiae $\beta$-tubulin sequence on the ben 4 mutant phenotype.

A ben4.D3 ura4.294 strain of $\underline{\mathrm{S}}$. pombe was constructed, and repeated attempts to transform cells of this strain to a $\underline{u r a}^{+}$phenotype with pRB129 were undertaken. Details of the separate transformation experiments carried out are given in Table 7.1. No ura $^{+}$ transformants were obtained from any of the transformation experiments involving either the ben 4 .D3 ura 4.294 or the ura 4.294 strains. In these experiments, a proportion (approximately 10-20\%) of proto- 
Table 7.1 Attempted transformation of ben4.D3 ura4.294 and ura4.294 cells with pRB129

\begin{tabular}{|c|c|c|c|c|}
\hline \multicolumn{2}{|c|}{ Strain } & $\begin{array}{l}\text { Number of } \\
\text { shaeroplasts }\end{array}$ & $\begin{array}{c}\text { Amount of } \\
\text { plasmid DNA added } \\
(\mu g)\end{array}$ & $\begin{array}{l}\text { Number of } \text { ura }^{+} \\
\text {transformants }\end{array}$ \\
\hline ben $4 . D 3$ & ura 4.294 & $1.5 \times 10^{7}$ & 5 & 0 \\
\hline & $"$ & $5.0 \times 10^{7}$ & 5 & 0 \\
\hline & $"$ & $2.0 \times 10^{8}$ & 8 & 0 \\
\hline & $"$ & $2.0 \times 10^{8}$ & 15 & 0 \\
\hline & $"$ & $3.6 \times 10^{8}$ & 5 (XhoI digested) & 0 \\
\hline & $"$ & $3.6 \times 10^{8}$ & 15( XhoI digested) & 0 \\
\hline$\underline{\text { ural }}$ & 4.294 & $3.6 \times 10^{7}$ & 5 & 0 \\
\hline & $"$ & $3.0 \times 10^{7}$ & 15 & 0 \\
\hline
\end{tabular}


plasts from either strain were able to regenerate fully when plated onto EMM regeneration agar supplemented with uracil. The failure to obtain ura $^{+}$transformants was therefore not attributable to massive inviability of sphaeroplasts induced by the experimental, procedure.

Evidently, the frequency of integration may be increased if the sequence to be integrated is cut once with a suitable restriction enzyme (Orr-Weaver et al., 1981). The linearisation of pRB129 can be achieved by virtue of a single XhoI site present in the B-tubulin coding region (Figure 7.1). A quantity of XhoI linearised PRB129 DNA was prepared and samples were used to transform a ben4.D3 ura 4.294 strain. No ura $^{+}$transformants were obtained using this approach (Table 7.1).

These negative results indicated that the $\underline{S}$. cerevisiae $\beta$-tubulin gene was unable to integrate by homologous recombination into the $\underline{S}$. pombe genome. However, even if the integration of pRB129 into the S. pombe genome had taken place by recombination at homologous $\beta-$ tubulin sequences, recent information suggests that the $\underline{S}$. cerevisiae URA3 gene fails to complement ( $P$. Russell, personal communication) or complements only very weakly (Filetici and Ballario, 1984) when in an integrated form in $\underline{S}$. pombe.

The experiments described in this section represented, in retrospect, a somewhat speculative approach. Clearly, a better method would be to sub-clone the fragment carrying TUB2 from pRB129 into a vector capable of autonomous replication in $\underline{S}$. pombe .

\subsection{Strategy for subcloning TUB2 into pDB248}

The vector pDB248 (Figure 7.2a) contains elements which permit the autonomous replication, as multiple copies, of the plasmid in $\underline{S}$. pombe (Beach and Nurse, 1981). This vector, which contains the LEU2 


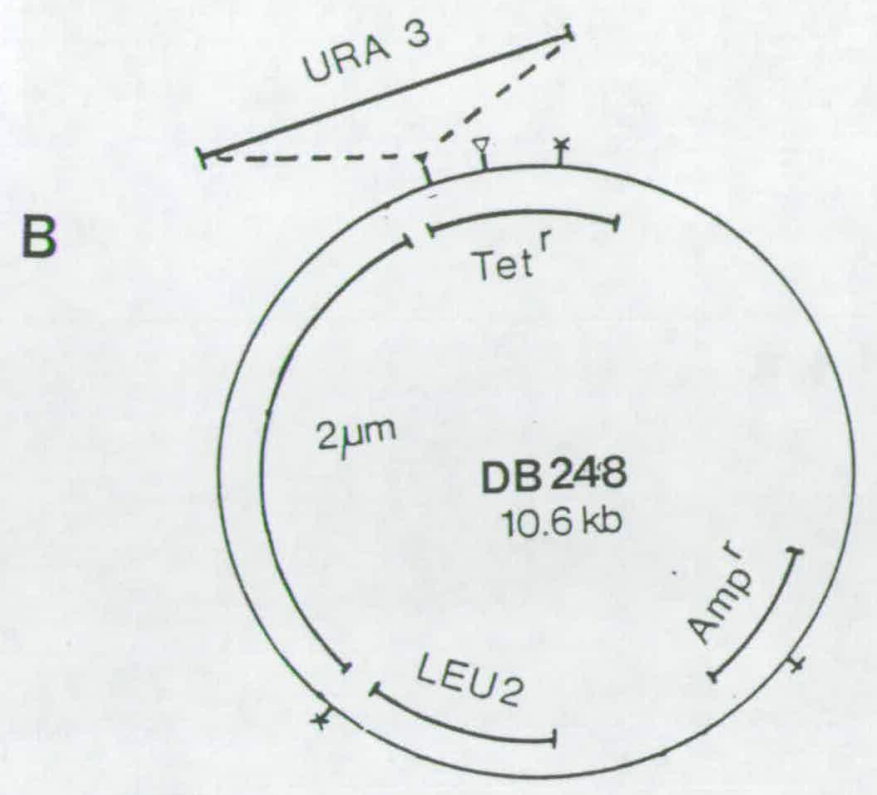

A

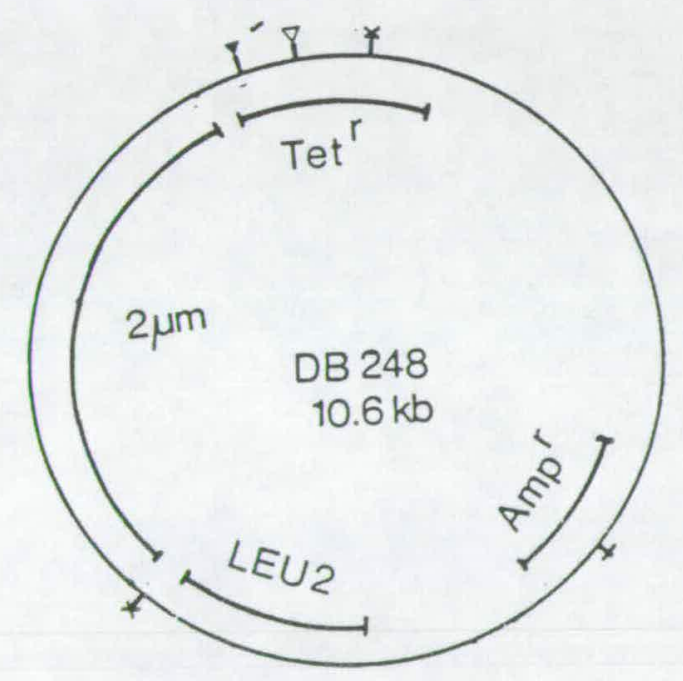

Figure 7.2 Diagramatic representation of plasmids pDB248 and pT2 (scale approximate).

A - pDB248 B - pT2.

\section{Symbols}

$\begin{array}{lll}\nsim \text { Bam HI } & \text { Tet }^{r} & \text { Tetracycline resistance } \\ \text { * Sal I } & \text { LEU } 2 & \text { Yeast leucine } 2 \text { gene } \\ \text { - Hind III } & 2 \mu \mathrm{m} & \text { Yeast } 2 \mu \mathrm{m} \text { circle DNA } \\ \text { — PstI } & \end{array}$


gene of $\underline{\mathrm{S}}$. cerevisiae, is capable of transforming a leul.32 strain of S. pombe to $\underline{\text { leu }}^{+}$at high frequency $\left(10^{3}-10^{4} \underline{1 e u}^{+}\right.$transformants per $\mu g$ of pDB248 DNA).

A direct subcloning strategy involved the insertion of the $4.1 \mathrm{~kb}$ BamH1 B-tubulin containing fragment into the BamH1 site of the pDB248 $\mathrm{Tc}^{\mathrm{r}}$ gene. One complicating factor was the presence of an additional $\underline{B a m H 1}$ site within the B-tubulin coding region. A partial BamH1 digest was therefore required to generate the desired fragment. Several time-course BamH1 digestions of pRB129 were carried out in order to define conditions to obtain optimum yield of the $4.1 \mathrm{~kb}$ fragment. Good yields of the $4.1 \mathrm{~kb}$ fragment appeared following fifteen minutes digestion using the conditions employed in Figure 7.3 . The next step in the subcloning strategy involved recovery of the $4.1 \mathrm{~kb}$ fragment from the agarose gel, prior to ligation into the BamH1 site of pDB248. Electroelution, recovery using low melting point agarose and the 'freeze-squeeze' technique are three well documented procedures for the recovery of DNA fragments from agarose gels. A series of pilot experiments were conducted to assess the efficiency of each of the above techniques for DNA recovery. These experiments utilised BamH1 linearised pDB248 as sample DNA to be recovered. A brief description of each of the methods used, including an estimate of the efficiency of recovery obtained, is to be found in the following sections.

\section{3a The 'freeze-squeeze' technique}

The procedure described by Thuring et al. (1978) was used. Briefly, the desired fragment is excised from the gel in a small quantity of agarose, which is then frozen at $-20^{\circ} \mathrm{C}$. The frozen agarose block is placed in a protective envelope of 'Parafilm' and squeezed between thumb and forefinger. The fluid exudate is collected and further processed to concentrate the DNA. Samples of linearised 


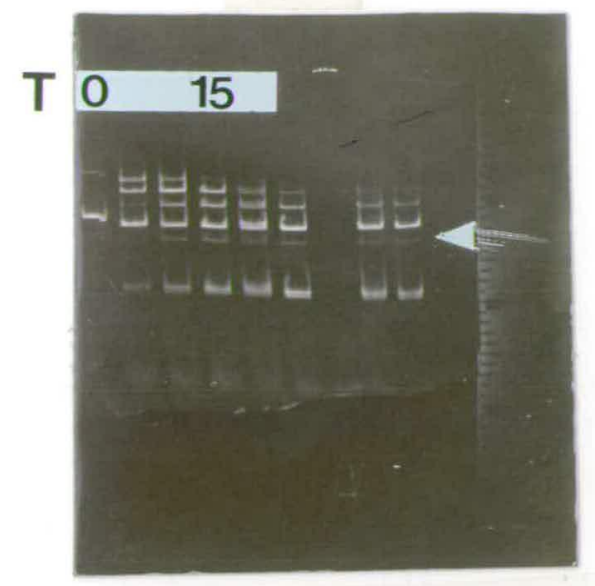

Figure 7.3 Time-course BamHI partial digestion of pRB129.

$40 \mu \mathrm{g}$ of pRB129 was taken up in $60 \mu \mathrm{l}$ of BamHI reaction buffer and digested with 0.8 units of BamHI at $37^{\circ} \mathrm{C}$. Samples $(6 \mu 1)$ were taken at 5 minute intervals from addition of enzyme (zero time point) and analysed by agarose gel (0.6\%) electrophoresis. Arrow indicates position of $4.1 \mathrm{~kb}$ fragment. Note enrichment of $4.1 \mathrm{~kb}$ fragment at the 15 minute time point. $\mathrm{T}$ - time in minutes from addition of the enzyme.

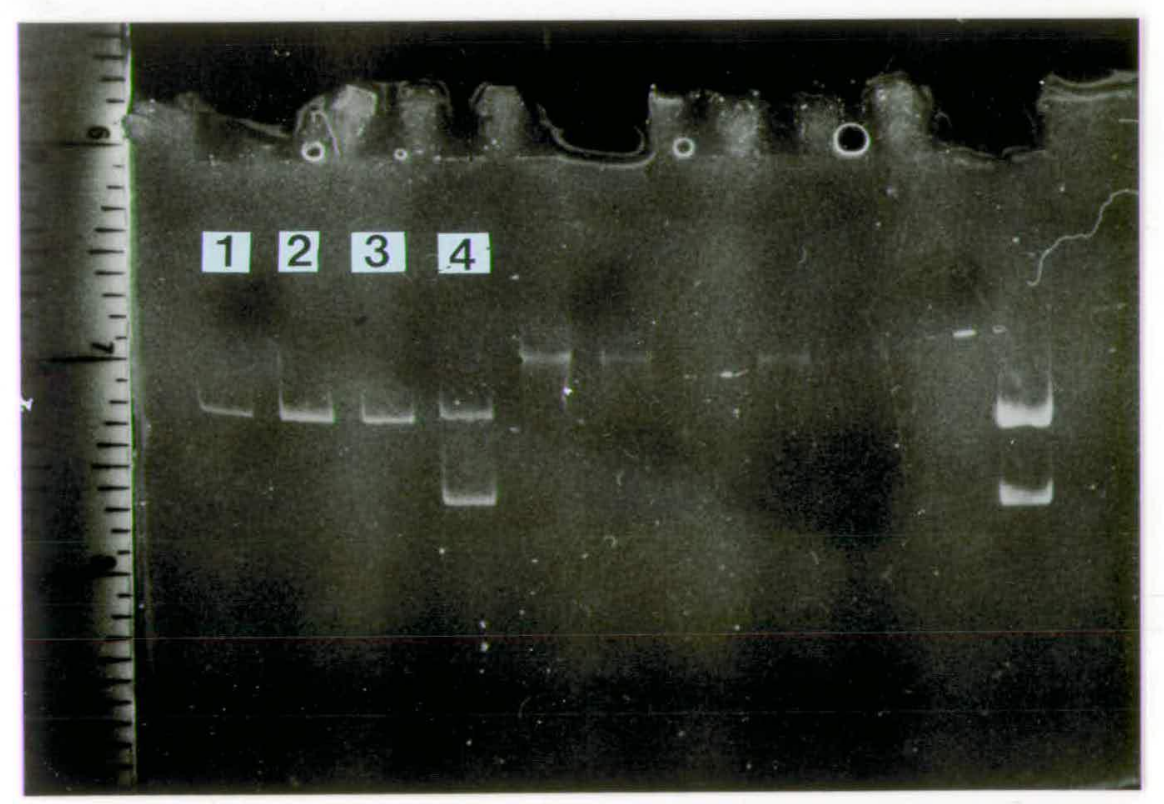

Figure 7.4 Recovery of pDB248 DNA using the 'freeze-squeeze' technique.

Samples $(1 \mu \mathrm{g})$ of BamHI linearised pDB248 were run out in a $0.7 \%$ agarose gel. Recovery of sample DNA was performed using the 'freeze-squeeze' technique (section 2.6k Gel above ( $0.6 \%$ agarose) shows efficiency of recovery obtained. Lanes 1 and 3 : each lane shows total sample recovered from a $1 \mathrm{\mu g}$ sample of pDB248 (fingers not pre-cooled - see text); Lane 2: total sample recovered from $1 \mu \mathrm{g}$ pDB248 sample (fingers pre-cooled - see text); Lane 4: $0.5 \mu \mathrm{g}$ of pDB248 DNA undigested. 
pDB248 were recovered from agarose gels using this technique.

One problem encountered was that, on squeezing, the agarose block warmed rapidly; consequently, the gel matrix broke up and fragments of agarose contaminated the fluid exudate. It was subsequently found that the frozen agarose matrix stayed largely intact if the fingers were pre-cooled in an ice bath prior to squeezing. Up to $50 \%$ of the sample could be recovered in this way (Figure 7.4).

\section{3b Recovery from low melting point agarose}

The method of Maniatis et al. (1982) was used. The technique makes use of the low gelling temperature of this type of agarose $(B R L):$ a $1.0 \%$ gel completely sets only at a temperature less than $28^{\circ} \mathrm{C}$. The desired fragment is removed from the gel in a small block of agarose which is then melted and subject to hot phenol extractions. The DNA is further purified and concentrated from the aqueous fraction. Using this technique, a recovery of 10-30\% was obtained.

\section{$7 \cdot 3 c$ Electroelution}

The basic procedure of Smith (1980), as modified by D. M. McSorley (personal communication), was used. The DNA fragment is cut from the gel and then eluted from the agarose block by electrophoresis in the apparatus described in Section 2.6k. The eluted DNA is trapped in a reservoir bounded by dialysis membrane. The reservoir fluid is removed and further processed to recover the DNA. Recovery of DNA using this technique was relatively poor: in no experiment was a yield of greater than about $10 \%$ achieved.

In these tests, the 'freeze-squeeze' technique gave the best DNA recovery and was technically simple. This technique was duly applied to the recovery of the $4.1 \mathrm{~kb} \beta$-tubulin fragment. 


\section{3d Recovery and attempted subcloning of the $4.1 \mathrm{~kb}$ B-tubulin}

fragment

Samples of pRB129 ( $3 \mu \mathrm{g})$ were digested with BamH1 under conditions favouring the production of the $4.1 \mathrm{~kb}$ fragment. Approximately $0.2 \mu \mathrm{g}$ of the $4.1 \mathrm{~kb}$ fragment was recovered in total, using the 'freeze-squeeze' technique. The recovered DNA was added to $0.2 \mu g$ of BamH1 linearised pDB248 in a ligation reaction, as described in Section 2.6i. After termination of the reaction, the ligation mixture was used to transform competent cells of $\underline{E}$. coli strain JA221. Selection for transformants was carried out on ampicillin containing media. However, ampicillin resistant colonies were obtained only at a low frequency (Table 7.2). None of these transformants were tetracycline sensitive, indicating that the transformants arose from either recircularisation of the vector or carry through of uncut pDB248. The ligation reaction control (re-ligation of linear pDB248) was also unsuccessful (Table 7.2), as judged from the low frequency of ampicillin resistant colonies recovered. The failure to subclone the $4.1 \mathrm{~kb}$ fragment was therefore attributed to a failure of the ligation reaction.

In a separate experiment carried out in this laboratory, the $4.1 \mathrm{~kb}$ BamH1 fragment of pRB129 was successfully cloned into the BamH1 site of pDB248 (D. Hughes, personal communication), although the precise orientation of the fragment within the plasmid was not ascertained. This plasmid was capable of transforming ben4.D3 leu 1.32 cells to a $\underline{\text { leu }}^{+}$phenotype. However, the presence of the TUB2 gene did not affect the ben 4 mutant phenotype: the level of benomyl resistance and of cold sensitivity exhibited by the transformants was indistinguishable from that of the ben4.D3 leu1.32 parental strain (D. Hughes, personal communication). These negative results suggested that the TUB2 gene was unable to complement the ben 4 mutant phenotype. 

Table 7.2 Attempted subcloning of $4.1 \mathrm{~kb}$ tubulin containing
fragment into pDB2 48.

\author{
Ligation \\ reaction \\ Number of \\ ampicillin resistant \\ transformants \\ recovered
}

4. $1 \mathrm{~kb}$ fragment

+ BamH 1 digested pDB248

Religation of

BamH 1 digested pDB248

BamH1 digested $\overline{\mathrm{pDB}} 248$ (no ligase)

pDB248 (undigested)

\author{
Number with \\ tetracycline \\ sensitive \\ phenotype
}

0

11

0

4

0

approximately

$10^{5}$ per $\mu g$ 
Nonetheless, the availability of the $\underline{\underline{s}}$. cerevisiae $\beta$-tubulin gene provided an opportunity to analyse $\beta$-tubulin sequences in $\underline{S}$. pombe, with the ultimate aim being the isolation of the $\beta$-tubulin gene from the latter organism.

7.4 Attempted detection of B-tubulin sequences in $\underline{\mathrm{S}}$. pombe

The Southern transfer technique is widely used for the detection of specific DNA sequences within genomic DNA. Commonly, genomic DNA is digested to completion with one or more restriction endonucleases and the fragments separated by gel electrophoresis. This is followed by transfer and immobilization of the DNA fragments to a nitrocellulose filter. A radio-labelled DNA probe is prepared and incubated with the immobilized DNA under conditions favouring DNA-DNA hybridization. Areas of hybridization are subsequently detected by autoradiography (Southern, 1975).

In this study, $\underline{\mathrm{S}}$. pombe genomic DNA was digested, separated by gel electrophoresis and immobilized onto a nitrocellulose filter. The plasmid pRB129 was then radiolabelled with ${ }^{32} \mathrm{p}$ and used directly to probe the $\underline{S}$. pombe genomic DNA for sequences hybridizing to the $\beta$-tubulin (TUB2) gene of $\underline{s}$. cerevisiae. It was considered that, apart from the $\beta$-tubulin sequence, the other yeast sequences present in pRB129 (the URA3 gene and sequences flanking the B-tubulin gene) would be unlikely to hybridize to sequences in the $\underline{S}$. pombe genome. Experiments to test the validity of this assumption were, however, carried out and are discussed later in the chapter.

Samples of $\underline{\mathrm{S}}$. pombe total DNA $(5 \mu \mathrm{g})$ were digested with each of the following restriction enzymes: BclI, SmaI, BamHI, HindIII, PstI and EcoRI. Each of these enzymes recognises and cleaves a hexanucleotide sequence of DNA. The digested DNA was separated by gel electro- 
phoresis along with samples $(5 \mu \mathrm{g})$ of undigested $\underline{\mathrm{s}}$. pombe total DNA and samples (0.200-0.002 $\mu \mathrm{g})$ of pDB248 DNA. After electrophoresis, the gel was stained with ethidium bromide and the pattern of DNA digestion visualised with U.V. illumination. Complete digestion of $\underline{S}$. pombe DNA was identified from the increased mobility of the DNA and also the appearance of discrete bands corresponding to the localisation of rDNA genes and other repeated sequences. The DNA samples were then denatured, transferred from the gel and immobilized onto a nitrocellulose filter as described in Section $2.6 \mathrm{~m}$. A sample ( $1 \mu \mathrm{g})$ of pRB129 was labelled with ${ }^{32} \mathrm{p}$ to a specific activity of $3.7 \times 10^{7}$

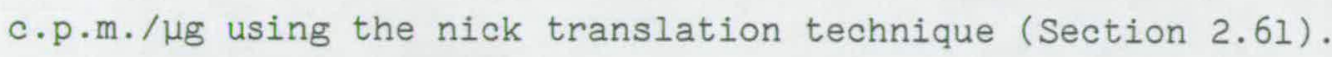
Hybridization of the probe to the pre-hybridized filter was carried out for 18 hours at $65^{\circ} \mathrm{C}$, after which the filter was washed extensively. Under these conditions, no hybridization of the pRB129 probe to any sequences in either the digested or the undigested $\underline{S}$. pombe DNA was found, despite prolonged exposure of the film (up to 10 days). However, strong hybridization of pRB129 to the samples of pDB248 DNA was detected (not shown) after overnight exposure, indicating that hybridization and autoradiography were working successfully.

This initial failure suggested that the hybridization conditions might have been too stringent to allow hybridization of the probe to sequences in $\underline{\mathrm{S}}$. pombe DNA. The experiment was repeated, and steps were taken, to reduce the stringency of the hybridization conditions. The amount of total $\underline{S}$. pombe DNA digested (using the same enzymes described above) was increased to $14 \mu \mathrm{g}$. As before, the digested DNA was separated electrophoretically along with samples of uncut $\underline{S}$. pombe and pDB248 DNA. $1 \mu \mathrm{g}$ of ${ }^{32} \mathrm{p}$ labelled pRB129 probe $\left(4.6 \times 10^{7} \mathrm{c} . \mathrm{p} . \mathrm{m} . /\right.$ $\mu_{\mathrm{g}}$ DNA) was added to the pre-hybridized filter. The stringency of hybridization was reduced by lowering the temperature from 65 to $47^{\circ} \mathrm{C}$ 
and increasing the incubation period at this temperature from 16 to 48 hours. The composition of the hybridization buffer ( $2 \times$ SSC, $5 \times$ Denhart's solution) and of the washing buffer ( 1 x SSC) were not altered. After four days exposure of the filter to the film, a series of discrete bands were observed amongst the $\underline{S}$. pombe genomic DNA (Figure 7.5). One or, more often, two bands appeared in a similar location, towards the top of each track containing $\underline{S}$. pombe DNA (Figure 7.5). These bands, which were apparently 'common' to digested and undigested samples, may represent the accumulation of relatively high molecular weight DNA. More interestingly, novel bands were detected, in addition to the 'common' bands described above, in several of the tracks containing digested DNA (Figure 7.5). The tracks corresponding to the $\underline{B c l} I$ and HindII digests contained a single novel band which generated a strong signal. In contrast, the EcoRI digest generated four novel bands, of which two generated a relatively strong signal.

In these experiments it was assumed that only the $\beta$-tubulin sequence present in pRB129 would hybridize to sequences in $\underline{S}$. pombe genomic DNA. However, the possibility that the other yeast sequences present in pRB129 (URA3 gene and B-tubulin flanking sequences) might also show significant hybridization to sequences in the $\underline{S}$. pombe genome could not be discounted. The following experiment was devised to test whether the URA3 gene of $\underline{S}$. cerevisiae would hybridize to sequences in $\underline{\mathrm{S}}$. pombe DNA.

A plasmid, designated PT2, has been constructed in this laboratory (P. Fantes, unpublished), in which the $\underline{S}$. cerevisiae URA3 gene was inserted into the HindIII site of pDB248 (Figure 7.2b). Since pDB248 does not hybridize to sequences in the $\underline{S}$. pombe genome ( $C$. Gordon, personal communication), plasmid pT2 provides an opportunity 


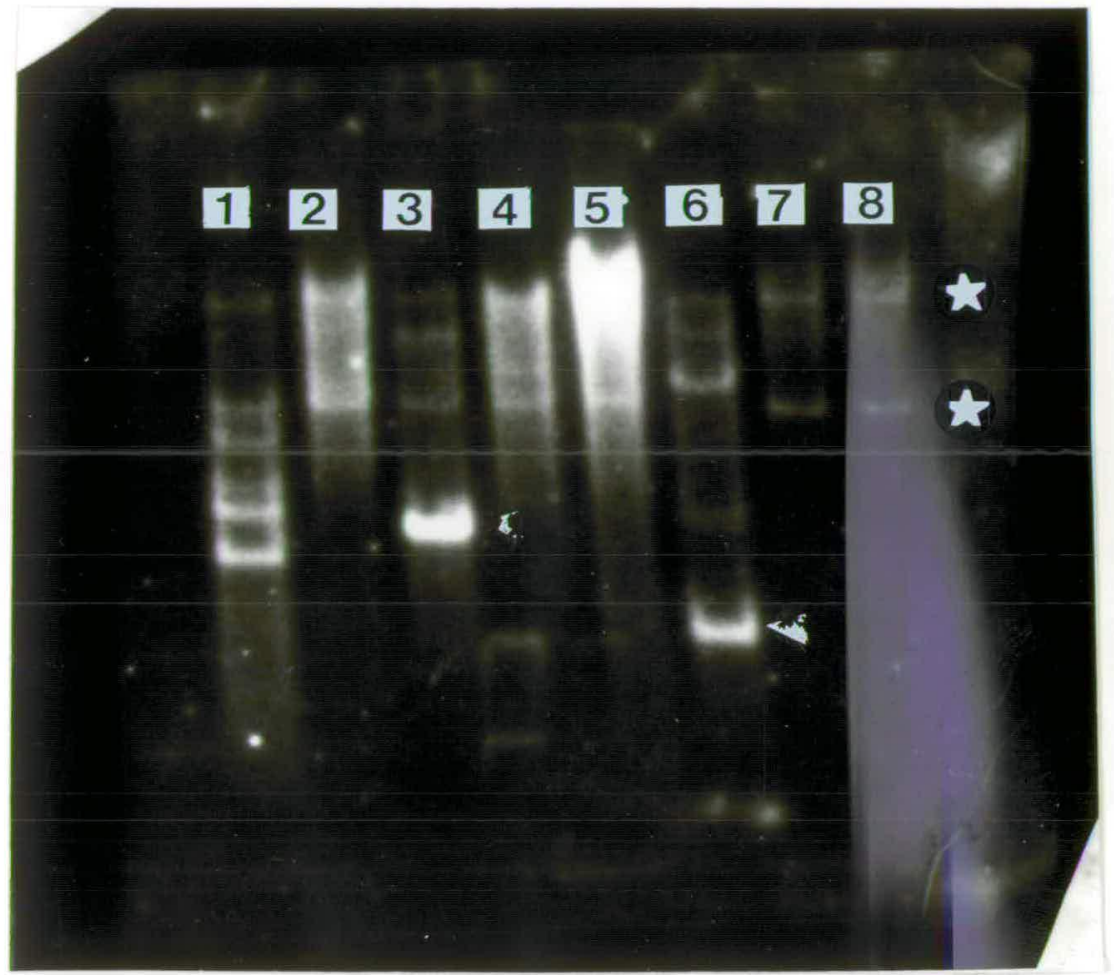

Figure 7.5 Hybridization of pRB129 to $\underline{\mathrm{S}}$. pombe DNA.

Lanes 1-8 represent $\underline{S}$. pombe DNA.

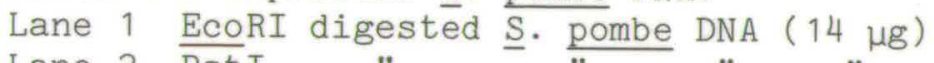

Lane 2 PstI " " " "

Lane 3 HindII " " " "

Lane 4 BamH $"$ " " "

$\begin{array}{llllll}\text { Lane } & 5 & \overline{\operatorname{San} I} & " & " & "\end{array}$

Lane 7 Undigested $\underline{S}$. pombe DNA $(3 \mu \mathrm{g})$.

Lane 8 Undigested $\underline{\bar{S}}$. pombe DNA $(6 \mu \mathrm{g})$.

Asterix refers to location of 'common' bands (see text). Arrowheads refer to location of novel bands producing a strong signal. 


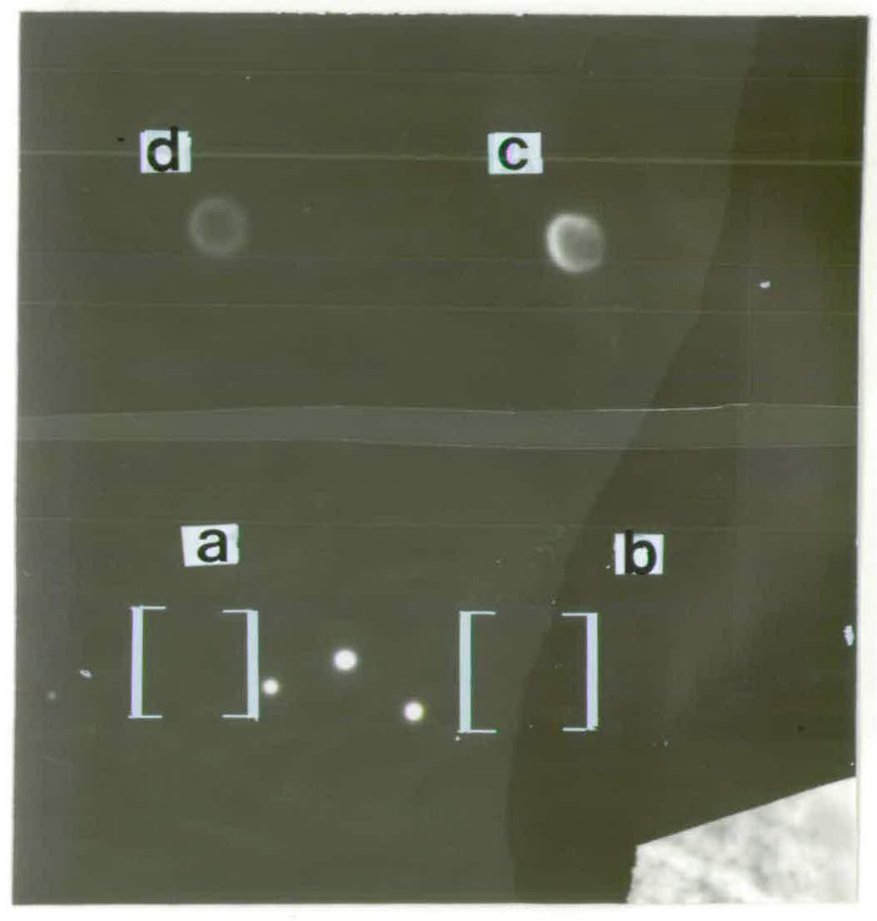

Figure 7.6 Hybridization of pDB248 and pT2 to $\underline{\underline{S}}$. pombe total DNA.

Film developed following four days exposure (see text for experimental details).

Sample

A - $56 \mu \mathrm{g}$ of $\underline{\mathrm{S}}$. pombe DNA probed with pT2.

B - $28 \mu \mathrm{g}$ of $\underline{\underline{S}}$. pombe DNA probed with pT2.

C - $56 \mu \mathrm{g}$ of $\underline{\underline{S}}$. pombe DNA probed with pRB129.

D - $28 \mu \mathrm{g}$ of $\underline{\bar{s}}$. pombe DNA probed with pRB129. 
to test whether the URA 3 gene of $\underline{\underline{S}}$. cerevisiae shows significant homology to sequences in the $\underline{S}$. pombe genome. An estimate of the extent of hybridization between the URA 3 gene and $\underline{s}$. pombe DNA was provided by the following semi-quantitative 'dot-blot' experiment. Duplicate filters were prepared by spotting samples of undigested $\underline{S}$. pombe total DNA onto nitrocellulose filters along with $0.5 \mu \mathrm{g}$ samples of pDB248 (Section 2.6m). Samples $(1 \mu \mathrm{g}$ ) of pT2 and pRB129 were labelled with ${ }^{32} \mathrm{P}$ to a specific activity of 4.9 and $4.6 \times 10^{7} \mathrm{c} \cdot \mathrm{p} \cdot \mathrm{m} /$ $\mu g$ of DNA respectively and used to probe, separately, one of the 'dot' filters described above. The hybridization conditions were identical to those used in the second hybridization experiment described above (Figure 7.5). Both PT2 and PDB248 hybridized strongly to the pDB248 DNA on each filter (not shown). The pRB129 probe hybridized relatively strongly to the $\underline{S}$. pombe DNA. By contrast, pT2 showed only extremely weak hybridization to $\underline{\underline{s}}$. pombe DNA under these conditions (Figure 7.6). From this result the conclusion is drawn that the $\underline{S}$. cerevisiae URA3 gene does not hybridize significantly to genomic DNA of $\underline{\mathrm{S}}$. pombe. From this, the pRB129 sequences which hybridize to $\underline{S}$. pombe DNA (Figure 7.5 ) are narrowed down to either the $B$-tubulin coding region and/or its flanking sequences of yeast DNA. Nonetheless, due to the conserved nature of $\beta$-tubuling gene sequences (Cleveland, 1983) it is reasonable to assume that some, if not all, of the bands of hybridization detected in Figure 7.5 correspond to $\beta$-tubulin sequences of $\underline{S}$. pombe.

It is very probable that the use as a probe in these sorts of hybridization experiments of a restriction fragment from within the TUB2 sequence (e.g. the SalI/ XhoI fragment, Figure 7.1) would have permitted the unambiguous detection of $B$-tubulin sequences in $\underline{S}$. pombe. Unfortunately, insufficient time was available in which to undertake these potentially rewarding experiments. 


\section{Chapter 8}

\section{DISCUSSION}

8.1 The nature of the mutant phenotype of ben 4 and hsR5 cells

8.1a Genetical Implications

In this study selection for benomyl resistance was found to enrich strongly for mutants with a cold sensitive cdc phenotype. Approximately $75 \%$ of mutants resistant to benomyl at $35^{\circ} \mathrm{C}$ exhibited reduced bulk growth and some degree of cellular elongation at $20^{\circ} \mathrm{C}$. In contrast, only a low proportion of the benomyl resistant mutants expressed a cold sensitive phenotype consistent with a defect in cellular growth.

Compared to the isolation of $\underline{S}$. pombe cdc mutants by direct screening of mutagenised cultures, the incorporation of selection for benomyl resistance afforded a remarkable enrichment for a cdc phenotype. For instance, Nurse et al. (1976) found that only 1\% of survivors from a mutagenised culture exhibited a heat sensitive defect, and of these 6\% exhibited a cdc phenotype. Toda et al. (1983) recovered, by direct screening, cold sensitive mutants at a frequency of $0.25 \%$; approximately $6 \%$ of those isolated expressed a cdc phenotype at the restrictive temperature.

Moir et al. (1982) have compared for $\underline{S}$. cerevisiae the relative yield of hs and $\underline{c s} \underline{c d c}$ mutants obtained from the same mutagenised culture; in this case $\underline{c s} \underline{c d c}$ mutants were recovered less frequently than $\underline{\text { hs }}$ ones. In $\underline{\mathrm{S}}$. cerevisiae recent attempts to identify additional cdc genes through the isolation of hs cdc mutants have not been successful. Most of the newly isolated hs cdc mutants map to existing loci (Moir et al., 1982; Pringle et al., 1984). It is clear that the 
genome of $\underline{S}$ : cerevisiae has become all but saturated for this sort of mutation. In view of this, Moir et al. (1982) have turned to the isolation of $\underline{c S} \underline{c d c}$ mutants as a means of expanding the number of $\underline{c d c}$ genes available for study. Six new cde genes have been identified in this way. However, a proportion of the mutants were found to map to a previously identified $\underline{c d c}$ gene. This analysis indicates that some genes appear to mutate to a hs cdc phenotype, whereas mutations in other genes confer predominantly a cs cdc phenotype. On the other hand, mutations in some cell cycle genes, cdc 11 of $\underline{\mathrm{s}}$. cerevisiae for example (Moir et al., 1982), may confer either a hs or a cs phenotype. Guthrie et al. (1969) have found that, in E. coli, selection

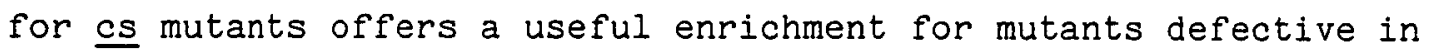
ribosome assembly. The isolation of hs mutants in this case did not significantly enrich for mutants defective in the process. It would seem then that the isolation of cs cde mutants offers a most useful means of identifying additional processes and components of the cell cycle, some of which may be unidentifiable by hs mutants.

The present study showed that the isolation of benomyl resistant cold sensitive mutants under the conditions employed (Figure 1.2) selects strongly for mutations at the ben 4 locus. The stringent nature of this selection scheme was underlined by the finding that benomyl resistant mutants which did not express a cs cdc phenotype mapped to loci other than ben4. Two additional loci were identified through the isolation of the mutants hsR5 and hsR10 which exhibited resistance to benomyl and a $\underline{h s} \underline{c d c}$ defect. Genetical analysis of $\underline{h s} R 5$

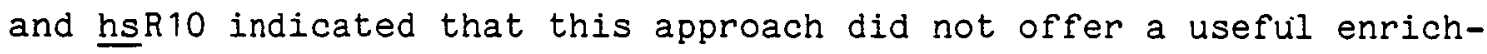
ment step for ben 4 mutants. Taken overall, this information points to the conclusion that the ben $4^{+}$gene product is predominantly susceptible to cold sensitive mutations. Even so, it may well be that only 
a limited number of mutations in the ben 4 gene are capable of conferring a benomyl resistant cold-sensitive cdc phenotype.

One mutant, ben4.C10, exhibits a less pronounced cs cdc phenotype than the other six mutants examined, although the degree of benomyl resistance is very similar. Presumably, the ben $4^{+}$gene product present in the different mutants is altered in different ways, thereby causing the observed differences in cdc phenotype. This would also explain the different changes in sensitivity to other antimitotic drugs. The heteroallelic diploid ben4.D23/ben4.D19 exhibited a level of benomyl resistance intermediate between that of the wild type diploid and the respective homozygous mutant diploids. This interaction indicates that D23 and D19 are indeed independent ben 4 alleles. The behaviour of heterozygous diploid strains compared with the corresponding homozygotes indicated that the benomyl resistance phenotype was a dominant or semi-dominant character whereas cold sensitivity was semi-dominant. These observations were consistent with ben 4 mutants showing an alteration, rather than a loss, of gene product function.

It was perhaps surprising that the selection of benomyl resistant cold sensitive mutants did not enrich for ben1 (nda3) mutants. The recovery of ben 1 mutants might have been expected since the ben 1 TB1005 mutation confers resistance to $\mathrm{MBC}$ and $\mathrm{TBZ}$ in addition to a cold sensitive mitotic defect (Umesono et al., 1983a). Less surprising is that no ben2 or ben 3 mutants were recovered along with ben 4 mutants. This is because the former mutants exhibit only weak cross resistance to $M B C$ and $T B Z$, and mutations at these loci do not appear to confer a temperature conditional cde phenotype (Yamamoto, 1980). It is unlikely that mutants defective in nda2 would have been recovered since mutations at this locus confer supersensitivity to 
antimitotic agents (Umesono et al., 1983a). In the present isolation scheme only benomyl resistant mutants with a cs cdc phenotype were selected for analysis. The phenotypic homogeneity of the mutants obtained was reflected in homogeneity at the genetic level: all mutants with this phenotype mapped to the ben 4 locus.

Many of the original isolates obtained carried an additional extragenic modifier which affected the drug resistance and cold sensitive phenotypes conferred by the ben 4 mutation. However, the modifier, of itself, did not confer an observable mutant phenotype. Further analysis of the modifier mutations might prove informative about proteins which interact with the ben $4^{+}$product.

Cold resistant revertants of ben $4 . C 10$ which exhibit a heat sensitive defect at $35^{\circ} \mathrm{C}$ were recovered at a low frequency. None of these, however, were found to express a cdc phenotype at the high temperature. Although the genetic basis of the revertants was not examined, this may indicate that proteins interacting with the ben $4^{+}$ product are also susceptible predominantly to $\underline{\text { s }}$ mutations. Quite possibly, a proportion of the ben $4 . C 10$ revertants might carry extragenic suppressor mutations. Such mutations have been of considerable value in the identification of genes whose products interact in discrete assemblies, particularly those involved in sequences of morphogenetic events. Of particular value in this respect are suppressors of $\underline{c s}$ or hs mutations which exhibit a temperature conditional phenotype of their own. Mutations of this sort are designated either Sup/Ts or Sup/Cs (Botstein and Maurer, 1982) depending upon whether the suppressor has a hs or $\underline{c s}$ phenotype respectively. This methodology is finding increasing use in genetical studies of morphogenetic processes but was first applied by Jarvik and Botstein (1975) to the study of bacteriophage assembly. More recently, Sup/Ts mutations have 
been utilized for the study of tubulin genetics in Aspergillus nidulans (Morris et al., 1979); the genetic control of the cell cycle in $\underline{S}$. cerevisiae (Moir et al., 1982) and also the biochemical and genetical analysis of flagellar proteins in Chlamydomonas reinhardii (Luck, 1984).

8.1b Physiological implications

\section{Nature of the cell cycle defect}

The ben 4 and hsR5 mutants exhibited late transition points which were consistent with the timing of mitosis. At the restrictive temperature, ben 4 cells exhibited an aberrant nuclear morphology, whereas hs R5 cells arrested with condensed chromosomes for several hours under these conditions. These findings provided strong evidence that the ben $4^{+}$and $\underline{\text { hs }} \mathrm{R5}^{+}$gene products are functionally required at mitosis. It has been argued by Pringle (1978) that the satisfactory assignment of transition points can best be made when many, or preferably all, of the mutant alleles of a cdc gene show approximately the same transition point values. This criterion appears to have been fulfilled in the case of the ben 4 gene: all of the mutants analysed had similar transition points, clustered around the timing of mitosis.

Processes of cellular growth continued in ben 4 and hsR5 cells in the absence of division. Cellular growth was monitored in this study from changes in cell length and culture turbidity; the accumulation of macromolecular components such as DNA, RNA and protein was therefore ill defined. However, the evidence discussed above indicates strongly that the ben 4 and hsR5 mutants are specifically defective in mitosis at the restrictive temperature.

During the course of this work a number of double mutants carrying $\underline{\text { hs }}$ ( $\underline{\mathrm{cdc}}$ ) and $\underline{\mathrm{cs}}$ (ben 4$)$ mutations in genes controlling progress through mitosis were constructed. It is likely that analysis of these double mutants by the reciprocal shifts method (Jarvik \& Botstein, 1973; Moir 
and Botstein, 1982) will yield information about the dependency relationships between mitotic functions controlled by ben $4^{+}$and $\mathrm{cdc}^{+}$ genes. Fantes (1982) has already shown that, in $\underline{S}$. pombe, events of mitosis controlled by certain cdc genes are arranged in a linearly ordered dependent sequence. By contrast, in $\underline{S}$. cerevisiae, the analy-

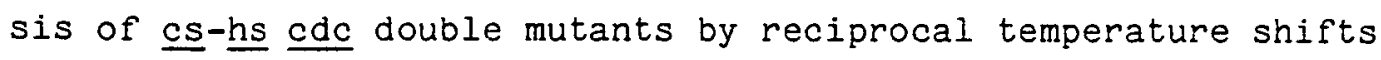
has shown that dependent events of mitosis exhibit a branched structure (Moir and Botstein, 1982). Also obtained in the present study were double mutants which harboured defects in ben 4 and either nda or $\mathrm{KM}$ genes. These double mutants should be of value in tests of epistasis since the $\underline{c s}$ phenotype of ben 4 mutants is very different from the phenotypes conferred by either nda or KM mutations. Tests of epistasis in this case should prove informative about the dependency relationships between mitotic events controlled by ben 4 , nda and KM genes (Fantes, 1982; Botstein and Maurer, 1982).

\section{Drug resistance phenotype}

None of the ben 4 mutants under examination showed significant cross resistance to inhibitors unrelated to benomyl. This provides evidence that the drug resistance phenotype is not conferred by a general defect in drug uptake or transport. The phenotype of ben 4 mutants contrasts with that of cyh4.U96, a mutant which exhibits multiple drug resistance (Johnston and Coddington, 1983). In this study it was shown that cyh4.096 is also resistant to benomyl and MBC. The molecular basis of the multiple drug resistance phenotype of cyh4. U96 has been traced to a defect in a membrane bound ATPase system (Johnston and Coddington, 1983). 
Despite the importance of benzimidazole carbamate drugs in agriculture, medicine and as research tools in biochemistry and cell biology, there is a paucity of information regarding the mechanism by which these compounds enter eukaryotic cells. In what is perhaps the only comprehensive study, Nachmias and Barash (1976) examined the uptake of isotopically labelled MBC into cells of Sporobolomyces roseus. The overall finding was that MBC enters the cell via an energy dependent uptake system. From this, it is conceivable that the altered sensitivity of cyh 4 mutants to $M B C$, benomyl and CIPC is also attributable to a defective membrane bound ATPase system. It is tempting then to speculate that the defective ATPase system in cyh 4 mutants normally functions as the central control point for the entry of benzimidazole compounds into $\underline{S}$. pombe. Mutations in ben 4 do not appear to confer significant cross resistance to other antimicrotubule agents. However, the group of strongly cold sensitive ben 4 mutants were supersensitive to CIPC. Several studies, mostly carried out with mammalian or plant cells, show that CIPC and its analogues ethyl-N-phenylcarbamate (EPC) and isopropyl-N-phenylcarbamate (IPC) exert their disruptive effect on mitosis by interfering with the normal functioning of the microtubule organising centres (MTOCs) of the mitotic spindle. Cells treated with CIPC, IPC or EPC accumulate supernumary MTOCs. As a result of this, multipolar spindles may be formed even in continued presence of the drug (Clayton and Lloyd, 1984; Oliver et al., 1978; Coss 1975; Hepler and Jackson, 1969). Walker (1982) and Ciffelli (1983) found CIPC to be an effective inhibitor 
of cell division in $\underline{S}$. pombe. The transition point for the action of CIPC (that is, the point in the cell cycle beyond which drug treatment no longer prevents division) was estimated by these workers to be 0.75 , a value consistent with a specific inhibition of mitosis. It was found that CIPC also perturbs cellular growth in $\underline{S}$. pombe; an effect which may be due to a direct inhibition of protein synthesis (Walker, 1982; Ciffelli, 1983). It is conceivable, however, that the main target of the drug in $\underline{S}$. pombe is a mitotic event such as nuclear microtubule assembly or functioning of the spindle pole body.

One line of genetical evidence supports the contention that CIPC interacts directly with microtubules in $\underline{S}$. pombe. Mutations at the nda2 ( $\alpha$ - tubulin) locus confer, in addition to a cold sensitive mitotic defect, supersensitivity to various antimitotic agents including EPC (Umesono et al., 1983a). This may be interpreted in the following manner: an alteration in the $\alpha$ - tubulin subunit, conferred by the nda2. KM52 mutation, results in increased binding of EPC to the tubulin dimer, thereby generating the observed drug supersensitivity. As discussed in Chapter 1, certain benA ( $\beta$ tubulin) mutants of Aspergillus nidulans exhibit MBC supersensitivity due to increased binding of the drug to the tubulin dimer (Davidse, 1975; Davidse and Flach, 1977). Furthermore, two mutants of A. nidulans defective in $\alpha$ - tubulin, tubA 1 and tubA4, also show supersensitivity to a variety of antimicrotubule agents (Gambino et al., 1984). A speculative model which accounts for the CIPC supersensitivity of ben 4 mutants may be derived from these observations. Quite possibly, the ben $4^{+}$product is closely associated with the tubulin dimer. If this were so, conformational alterations 
in the ben $4^{+}$product may result in the dimer becoming more susceptible to CIPC due to the unmasking of additional drug binding sites. In a similar way, the same alterations in the ben $4^{+}$product may mask benomyl and MBC binding sites and thereby confer resistance to these compounds.

The evidence discussed in this section shows that the drug resistance phenotype is not due to a general uptake defect. Rather, benomyl and MBC resistance would appear to be conferred by an alteration in either the target molecule of the drug or a protein closely associated with it. Resistance of fungal cells to toxic compounds may be brought about by mechanisms other than defective uptake or alteration of the target molecule; alternative mechanisms include: gene amplification (Fogel and Welch, 1982); the operation of alternative pathways (Georgopolous, 1975), and the operation of intracellular detoxification mechanisms (Georgopolous, 1975; Davidse, 1976). However, the dual benomyl resistant cold sensitive cdc phenotype of ben 4 mutants is most consistent with an alteration in a component of the mitotic machinery.

\section{1c Cytological implications}

Ben 4 mutants

A detailed cytological examination of the nuclear arrest morphology of ben 4 cells was undertaken in an attempt to identify the process primarily defective in the mutants. A diagrammatic representation of the terminal phenotype of ben 4 cells, built up from the various cytological observations made in this study, is presented in Figure 8.1. Also given in this Figure is a representation of the normal stages of mitosis in $\underline{S}$. pombe: this sequence is a composite drawn from the observations reported by several workers (McCully and Robinow, 1971; Mitchison, 1970; King and Hyams, 1982; Toda et al., 1981). The aberrant nuclear morphology in ben 4 cells is not identical 

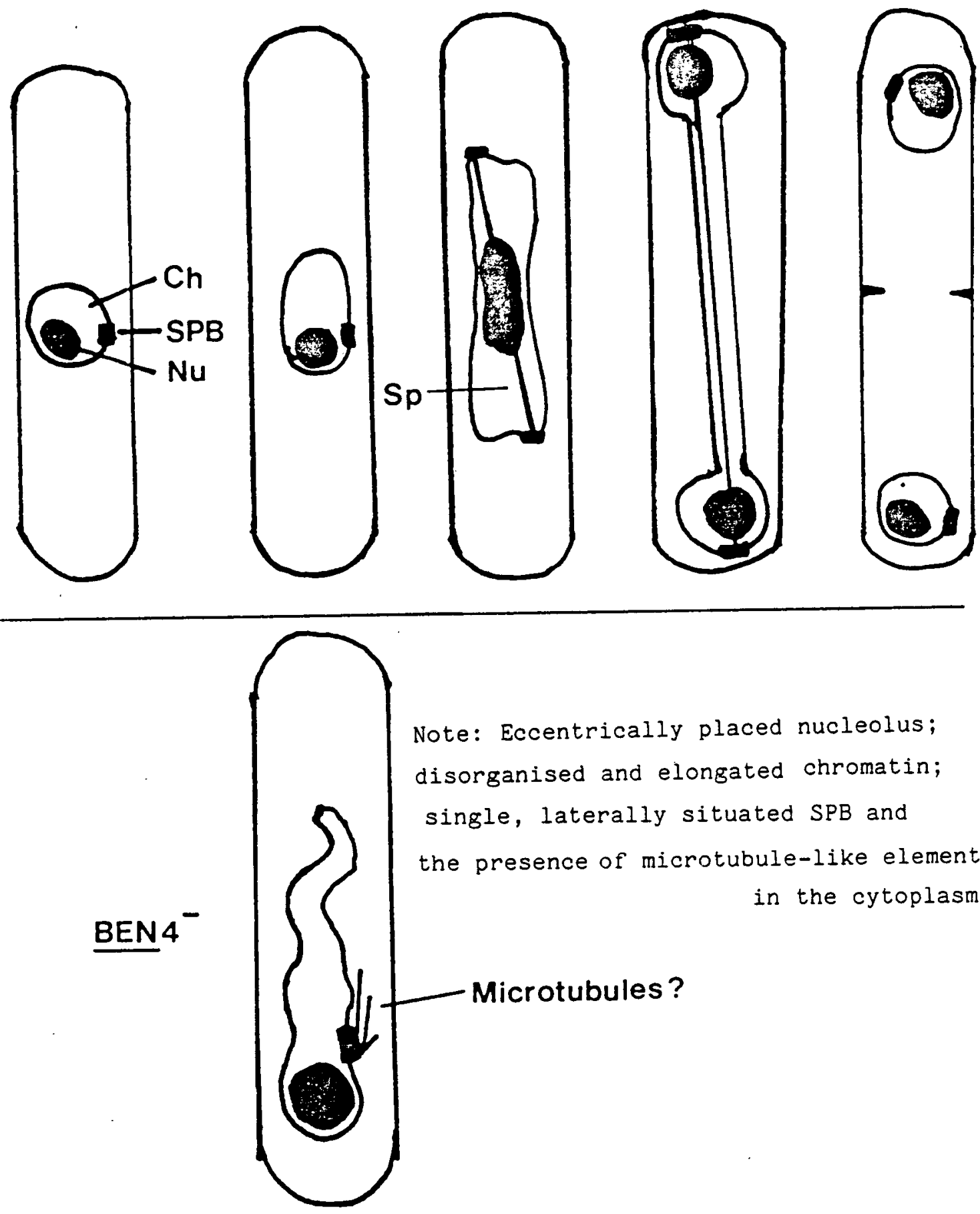

Figure 8.1 Diagramatic representation of the terminal phenotype of ben 4 mutants, and the normal-stages of mitosis in S. pombe.

Normal mitosis

Stage a. Configuration of interphase nucleus

b. Chromatin extension

c. SPB separation, spindle formation and elongation of the nucleus

d. Spindle elongation and segregation of daughter nuclei

e. Cytokinesis.

ben $4^{-}$: Terminal phenotype of ben4 cells. 
to any arrangement seen during the normal mitotic cycle of this organism. None of the existing cdc mitotic mutants appear to exhibit the striking chromatin disorganisation seen in ben 4 mutants. However, arrested cdc 1.7 cells contain an elongated nucleus in which the single nucleolus lies to one end of the rectangular shaped chromatin mass (King and Hyams, 1982). Cells of strain ED.22, from which the mitotic mutant $\underline{\text { dc }} 25.22$ was derived, exhibit elongated nuclei at the restrictive temperature, although no information was provided as to the location of the nucleolus (Nurse et al., 1976). Strains carrying the cdc25 alleles 22, M51 and 43 show disorganised chromatin at the restrictive temperature, although the degree of nuclear elongation is not marked (King and Hyams, 1982). Clearly, the aberrant nucleus in arrested ben4 cells does not represent a 'frozen' stage of normal mitosis. In particular, the distribution of chromatin along the very elongated nucleus is not normally seen, nor is the terminal position of the apparently undivided nucleolus. This suggests that ben 4 nuclei enter an abnormal developmental course following shift to the restrictive temperature. Pringle (1978) has argued that by their very nature terminal phenotypes can never be considered simply as a normal stage of the cell cycle.

Two reports (King and Hyams, 1982, and Mitchison, 1970) suggest that the earliest observable mitotic event in $\underline{S}$. pombe involves partial extension of nuclear chromatin prior to SPB duplication (represented as Stage B, Figure 8.1). Since ben $4^{-}$nuclei contain strikingly elongated chromatin as well as a single SPB and a terminally located nucleolus, it may be that the terminal phenotype of ben 4 cells represents a continuation of the early event of chromatin extension, in the absence of SPB separation. An important question concerns the mechanism by which chromatin extension is brought about 
in wild type and ben $4^{-}$cells. It is unlikely that nuclear microtubules play a role in chromatin extension since the process appears to occur in the absence of SPB separation in wild type (King and Hyams, 1982) and ben $4^{-}$cells. Alternatively, either localised nuclear membrane forces or a system of cytoplasmic microtubules have been proposed as primary mediators of chromatin extension. These possibilities are considered in turn below.

In prokaryotes, evidence suggests that the replicating chromosome is attached to sites on the plasma membrane (Leibowitz and Schaechter, 1975). It has been proposed that localised expansion of the plasma membrane acts as a 'motor' for the subsequent segregation of daughter chromosomes (Leibowitz and Schaechter, 1975). Localised membrane forces have been implicated to play a key role in the early evolution of eukaryotic mitosis (Kubai, 1975). In certain extant dinoflagellates, localised expansion of the nuclear membrane is considered to provide the primary motive force for chromosome segregation (Ris, 1975). Some workers consider that the initial separation of SPBs in yeast mitosis is brought about through expansion of the nuclear memorane (McCully and Robinow, 1971; King and Hyams, 1982; Peterson and Ris, 1976). However, direct experimental evidence that nuclear membrane forces play a direct role in later stages of fungal mitosis is almost totally lacking.

The alternative proposal that a system of cytoplasmic microtubules mediates the motive force for chromatin extension seems more attractive. A number of studies implicate cytoplasmic microtubules as direct force mediators for the migration of nuclei and transport of other organelles within fungal cells (Heath, 1981; Howard and Aist, 1980; Oakley and Morris, 1980). Cytoplasmic microtubules are also associated with SPBs during stages of mitosis in Fusarium oxysporum (Aist and 
Williams, 1972; Aist and Berns, 1981), ‥ cerevisiae (Zickler, 1981) and certain other genera of fungi (reviewed by Heath, 1981). Cytoplasmic microtubules are almost certainly present in vegetative cells of $\underline{S}$. pombe, although most reports of these elements represent fortuitous sightings either in cdc mutants or regenerating protoplasts (King and Hyams, 1982; Streiblova et al., 1984; Hereward, 1974). No detailed study of either the temporal or spatial organisation of cytoplasmic microtubules within the vegetative cycle has been undertaken. Nevertheless, cytoplasmic microtubules are associated with the single SPB present in arrested nuclei of cdc27.K3 cells (King and Hyams, 1982). This suggests that cytoplasmic microtubules are involved, if only transiently, in the early stages of mitosis in $\underline{S}$. pombe. Ultrastructural analysis of chromatin behaviour during $\underline{S}$. pombe meiosis provides further evidence for the involvement of cytoplasmic microtubules in nuclear elongation. Hirata and Tanaka (1982) have shown that extensive chromatin elongation takes place during prophaseI of meiosis in $\underline{S}$. pombe. A bundle of cytoplasmic microtubules, which emanates from the single SPB present at this stage, runs parallel and in close association with the much elongated nucleus.

These studies suggest that cytoplasmic microtubules may well mediate the motive force for chromatin extension in $\underline{s}$. pombe mitosis. One speculative hypothesis is that the aberrant nature of ben 4 nuclei is due to a malfunction in such a system. It may be envisaged that in ben 4 cells the proposed system of cytoplasmic microtubules becomes blocked in function, thereby generating a much elongated nucleus. The observation that in ben $4 . D 3$ cells a system of microtubule-like elements is associated in the cytoplasm with the single SPB and elongated chromatin (see Plate 6.8e) may be offered in support of this hypothesis. Since arrested ben 4 cells appear to contain a single SPB 
it is unlikely that the nuclei of such cells would contain a blocked mitotic spindle. Indeed, no cytological evidence for the presence of such a structure in these cells was found. However, nuclear microtubules, if present, may not have been preserved during specimen preparation. Attempts to detect microtubuies with the anti-yeast tubulin antibody YOL/34 were also unsuccessful. Hiraoka et al (1984) have also been unable to detect microtubules in $\underline{S}$. pombe with this antibody. This suggests that the antigenic determinants recognised by YOL/34 are not a feature of $\underline{s}$. pombe tubulin. The available evidence, however, suggests that chromatin extension in arrested ben 4 cells takes place in the absence of a fully formed mitotic spindle. Byers (1981) has demonstrated that mutants of $\underline{S}$. cerevisiae defective in cdc 31 arrest with a single duplicated but non-separated SPB. A short mitotic spindle is able to form on the nuclear face of the SPB, whereas the development of cytoplasmic microtubules does not appear to be impaired. The short unipolar mitotic spindle in these cells is not competent to segregate chromosomes.

The probable absence of a mitotic spindle in arrested ben 4 cells suggests that the spindle plays an organisational role rather than a force generating one, consistent with the findings of Aist and Berns (1981). This report describes, in Fusarium oxysporum, the acceleration of daughter nuclei away from each other following microbeam descruction of the spindle: deceleration of nuclei occurs following irradiation beyond the ends of the spindle. One implication from these experiments is that a system of cytoplasmic microtubules associated with the poles of the spindle generates or transmits the forces required for telophase elongation.

It is unlikely that the disorganised nature of the chromatin in ben 4 cells is associated with breakdown of the nuclear membrane. This 
is because mitosis is completed rapidly in such cells on return to the permissive temperature. Furthermore, observations at the ultrastructural level reveal that the nuclear membrane remains intact around extensive regions of the elongated nucleus.

The relative location of the nucleolar and chromatin regions within ben 4 cells was similar for each mutant examined. It was not easy to determine precisely the mechanism by which the nucleolus attained an eccentric location within the cell. Time-course analysis indicated that chromatin elongation and terminal positioning of the nucleolus occurred simultaneously following temperature shift down. It may be that the nucleolus is displaced terminally as a consequence of the proposed forces (discussed above) which generate chromatin elongation and disorganisation.

The group of strongly cs ben 4 mutants exhibited slight curvature in cellular morphology at $35^{\circ} \mathrm{C}$. This defect was particularly evident in certain ben $4 \mathrm{cdc}^{-}$double mutants. The strikingly curved morphology is consistent with a malfunction in a component responsible for maintaining the normal orientation of wall growth. There is good evidence that cytoplasmic microtubules play an essential role in the maintenance of cell wall topography in fungal and other cell systems (Toda et al., 1984; Streiblova et al., 1984; Clayton and Lloyd, 1984). This information again suggests that ben 4 mutants are defective in functions attributable especially to cytoplasmic microtubules.

Mutant hsR5

A complex sequence of morphological events led to the formation of the hsR5 terminal phenotype (Figure 6.1). Of particular interest was the occurrence of chromosome condensation between four and seven hours post shift. This finding is of significance since chromosome condensation is not normally discernible during the mitotic cycle of 
this organism (McCully and Robinow, 1971; Toda et al., 1981; King and Hyams, 1982). Chromosome condensation does however occur during meiosis in $\underline{S}$. pombe (Robinow, 1977) and $\underline{S}$. cerevisiae (Kuroiwa et al., 1984). Some hsR5 ${ }^{-}$cells contained up to six chromosome-like bodies scattered throughout the cell. This is consistent with the segregation of daughter chromosomes, and suggests that a partially functional spindle may be present within these cells. Conditional mitotic mutants of $\underline{s}$. pombe defective in nda2 ( $\alpha$-tubulin), nda 3 ( $\beta$-tubulin) (Umesono et al., 1983b) and cdc13 (Nasmyth and Nurse, 1981) also exhibit chromosome condensation at the restrictive temperature, as do a low proportion of wild type cells when treated with the antimitotic agent TBZ (Umesono et al., 1983b). The high resolution and specificity afforded by DAPI staining (see section 6.5) has facilitated the study of chromosome strucure in nda2.KM52 and nda3.KM311 cells. This approach should also be of value in analysing the condensed chromosomes within arrested hsR5 cells. Examination of hsR5 cells at the ultrastructural level may yield further information concerning spindle, kinetochore and chromosome structure in this organism.

After prolonged incubation at $35^{\circ} \mathrm{C}$, the proportion of septated

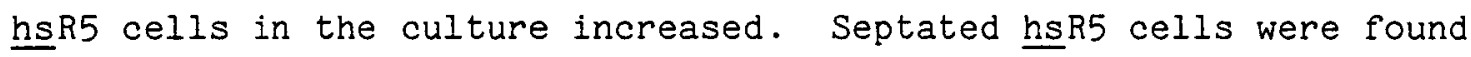
to fall into either of two morphological classes (see section $5.4 \mathrm{c}$ and Figure 6.1): Type $X$ cells contained a single nucleus located in one of the cytoplasmic compartments formed by septum, whereas Type $Y$ cells contained two nuclei within a single compartment. Type $X$ and Type $Y$ cells were reminiscent of stages in the formation of the nda2.KM52 terminal phenotype. Immediately after shift down to the restrictive temperature, nda2.KM52 cells arrest with a single terminally displaced nucleus (Toda et al., 1983). Although not explicitly stated, some of the data in this report (e.g. Figures 5b, $c$ and $d$ in Toda et al., 1983) 
indicates that a centrally located septum is laid down in a proportion of these uninucleated cells. This phenotype closely resembles that of Type $\mathrm{X}$ hs $\mathrm{R} 5$ cells. With prolonged incubation at $22^{\circ} \mathrm{C}$ partial separation of daughter nuclei and deposition of a transverse septum (if one is not already present) takes place, thereby generating an anucleate compartment within nda2. KM52 cells. This phenotype is reminiscent of Type $\mathrm{Y}$ hsR5 cells. Between six and ten hours after temperature shift down approximately $1 \%$ of nda2.KM52 cells exhibit. chromosome condensation (Umesono et al., 1983b).

Certainly, a proportion of hs $\mathrm{RS}^{-}$cells lay down a septum in the absence of nuclear division. This represents a malfunction in the control which normally maintains the dependency of septation on the defective in prior completion of mitosis. It is notable that mutants/cdc 13 , nda2 and nda 3 may arrest with condensed chromosomes and also exhibit a septated phenotype. This indicates that septation in $\underline{S}$. pombe is dependent on the completion of certain early stages of mitosis, up to and possibly including chromosome condensation. An analogous control system appears to operate in $\underline{S}$. cerevisiae. Here, a.number of studies with cdc mutants and antimitotic agents demonstrate that septation may simply be dependent upon duplication of the mass of the SPB (Byers, 1981; Adams and Pringle, 1984; Quinlan et al., 1981).

\subsection{Genetics of tubulin in $\underline{S}$. pombe}

Throughout this study it was considered a possibility that the ben 4 gene coded for a B-tubulin protein. By analogy with other systems, in particular the benA and tubA mutants of A. nidulans (Morris, 1980), the following lines of evidence may be offered in support of this hypothesis. Firstly, genetical analysis showed that the benomyl resistance and cold sensitive cdc phenotypes were the result of a single gene 
mutation. Secondly, physiological characterisation identified that the cold sensitive defect was in a process in or related to mitosis. Cytological analysis revealed that mutant cells arrested at the restrictive temperature with a single aberrant nucleus. This suggested that a defect in the mitotic machinery was the cause of the cell cycle defect. Thirdly, six of the seven ben 4 mutants exhibited increased sensitivity to the spindle poison CIPC. Finally, the same six ben 4 mutants exhibited a defect in the orientation of cell wall growth at the high temperature. This observation was considered to offer circumstantial evidence that the $\underline{b e n}^{4}$ mutation perturbs a microtubule based system required for the normal orientation of wall growth.

Recently, Yanagida and his colleagues have succeeded in unravelling the genetics of tubulin in $\underline{S}$. pombe. In a rationale similar to the one employed here, and with the aim of identifying tubulin mutations, they analysed mutants defective in nda2 and nda3 which exhibited a cold sensitive mitotic defect and an altered sensitivity to benzimidazole compounds. As with ben 4 mutants, the pleiotropic phenotype of nda2 and nda3 mutants (Umesono et al., 1983a; see also section 4.11c) strongly implied that these genes were intimately involved in microtubule mediated processes. The physical isolation of nda 2 and nda 3 genes by yeast transformation and recombinant DNA techniques has allowed this hypothesis to be tested directly (Toda et al., 1984). Two independent $\underline{S}$. pombe DNA sequences, designated (NDA2) 1 and (NDA2)2 were found to complement the nda2.KM5 mutant phenotype. A series of subcloning experiments was conducted in order to delimit the complementing activity of the cloned fragments. Nucleotide sequence analysis showed that the (NDA2) 1 and (NDA2) 2 subclones each carried coding capacity for an $\alpha$-tubulin protein. With this information the (NDA2) 1 and (NDA2) 2 subclones were designated $\alpha 1-$ and $\alpha 2-$ tubulin clones 
respectively. Integration experiments established that the $\alpha-1$ tubulin

clone represented the nda2 structural gene, whereas the $\alpha-2$ clone was mapped to a locus distant from nda2. In a similar approach, the nda 3 gene has been cloned and identified as a structural gene for B-tubulin (Hiraoka et al., 1984). Biochemical evidence suggests that two $\alpha$ - and one $B$ - tubulin polypeptide species are expressed during vegetative growth of $\underline{\mathrm{s}}$. pombe (Toda et al., 1984).

Genetical analysis carried out in this present study established that ben4 was linked to neither nda2 nor nda3. The possibility of linkage between ben 4 and the a2- tubulin gene has been tested by Toda et al. (1984); this investigation showed that ben 4 and the $\alpha-2$ tubulin gene. were unlinked. In view of these findings it would appear unlikely that ben 4 codes for a tubulin protein, although the possibility that ben 4 represents an undetected tubulin gene cannot be ruled out entirely. The phenotypic properties of arrested hsR5 cells were similar to those of mutants defective in nda2 and nda3. This raises the possibility that hs $\mathrm{R} 5$ cells may also carry a tubulin mutation. The possibility of allelism between hs $R 5$ and nda 2 has been ruled out in this study. However, the intriguing possibility that hs R5 is allelic to either nda 3 or the $\alpha 2-$ tubulin gene remains to be tested. A plasmid (pRB129) containing the $\beta$-tubulin gene (TUB2) from $\underline{S}$. cerevisiae was used in the present study as a hybridization probe in attempts to identify $\beta$-tubulin sequences in $\underline{S}$. pombe. Although not unambiguously demonstrated, it is very likely that the regions of hybridization detected in $\underline{S}$. pombe DNA with this approach (see section 7.4) correspond to sequences homologous to $\beta$-tubulin. Extension of these experiments may ultimately have offered an alternative approach for the physical isolation $\underline{S}$. pombe B-tubulin gene(s). For instance the TUB2 gene might have been used to screen, by in situ hybridization 
techniques (Grunstein and Hogness, 1975), bacterial cells transformed with an $\underline{S}$. pombe 'gene bank' for the presence of plasmids containing S. pombe $\beta$-tubulin DNA sequences.

The availability of conditional tubulin mutations allows one to assay the cellular effect of the tubulin lesion by simple alteration of growth temperature. Mutations in nda2 ( $\alpha$-tubulin) and nda 3 ( $\beta-$ tubulin) confer defects in mitosis, nuclear location and the orientation of wall growth. A similar spectrum of phenotypes is seen in wild type cells treated with inhibitory concentrations of benomyl or MBC (Walker, 1982; Fantes, 1982; P. Fantes, personal communication). These results provide strong evidence for the role of microtubules not only in mitosis but also in wall growth and positioning of the nucleus. In $\underline{\mathrm{S}}$. cerevisiae the results from a combined genetical, cytological and pharmacological approach point to the importance of microtubules in mitosis, nuclear migration and morphogenetic events associated with the budding process (Byers, 1981; Byers \& Goetsch, 1975; Adams \& Pringle, 1984). Of particular interest to this thesis is the effect of $\alpha$ - and $\beta$ - tubulin mutations on mitosis in $\underline{S}$. pombe. Arrested nuclei of nda2. KM52 cells contain duplicated and separated SPBs, but a spindle is unable to form between them. In contrast, nda3.KM311 mutants appear to arrest at $22^{\circ} \mathrm{C}$ with a complete mitotic spindle which links the two well separated SPBs (Umesono et al., 1983a). Recent evidence, however, suggests that a spindle does not form in these cells when incubated at $20^{\circ} \mathrm{C}$ (Hiraoka, 1984 ). Analogous examples of these two morphologies are shown by two mutants of $\underline{A}$. nidulans, both of which are defective in the benA gene and are conditionally defective for mitosis (Oakley, 1981; Oakley and Morris, 1981). Mutant benA33 arrests with a complete spindle (Oakley and Morris, 1981), although chromosome segregation does not occur. Mutant benA31 on the other hand fails to construct a 
spindle (Oakley, 1981). Oakley and Morris (1981) consider that the benA33 phenotype results from 'hyperstabilization' of the spindle. In support of this it was found that suppression of benA33 phenotype could be brought about by treatment with various antimicrotubule agents or by inclusion of either of the $\alpha$-tubulin mutations tubA 1 or tubA 4 in strains carrying the benA33 mutation (Oakley and Morris, 1981; Gambino et al., 1984). The implication is that either drug treatment or presence of an altered $\alpha$-tubulin suppresses the benA33 mutant phenotype by 'destabilizing' the spindle microtubules. Another important point to emerge from study of the benA33 phenotype is that chromosome segregation requires disassembly of spindle microtubules. Such information will be of great value in discrimination between the many models currentiy proposed to account for the mechanisms of mitosis (see Reviews by Heath, 1981 and Pickett-Heaps et al., 1982).

\subsection{Tubulin mutations in other organisms}

Selection for resistance to antimicrotubule agents has now been used to identify tubulin mutations in the following systems: $\underline{S}$. pombe, A. nidulans, $\underline{\text { S. }}$ cerevisiae, Physarum polycephalum and in Chinese hamster ovary ( $\mathrm{CHO}$ ) cells. The first two of these examples have been discussed previously and will not be covered further in this section. The remaining examples are described below.

As discussed in section 7.1 , mutants defective in the TUB2 gene of $\underline{S}$. cerevisiae exhibit a benomyl resistant cold sensitive phenotype. The TUB2 gene was subsequently found to code for a B-tubulin. Biochemical and genetic evidence (Neff et al., 1983) established that a single $\beta$-tubulin gene is present in this organism. Gene disruption experiments have demonstrated that $\beta$-tubulin serves an essential function in the life cycle of $\underline{S}$. cerevisiae (Neff et al., 1983). 
In $\underline{S}$. pombe the $\alpha$ - and $\beta$ - tubulins coded by the nda2 and nda 3 genes respectively have an essential function in vivo (M. Yanagida, personal communication). In contrast, the $\alpha 2-$ tubulin is not essentially required during vegetative growth.

At least four loci, benA, B, C and $D$, control resistance to benzimidazole compounds in the slime mould Physarum polycephalum (Burland et al., 1984). A mutation at the bend locus, bend.210, confers an altered mobility on a B-tubulin protein when analysed by two dimensional gel electrophoresis. Further experiments have ruled out the possibility that the alteration is due to post-translational modification; therefore, bend represents the structural gene for a $\beta-$ tubulin protein (Burland et al., 1984). An in vitro mapping technique has been used to identify additional tubulin genes in this organism. Use is made of natural polymorphic variations in restriction enzyme digestion products of $\alpha$ - and $\beta$ - tubulin genes between different haploid strains of $\underline{P}$. polycephalum (Schedl et al., 1984b). Heterozygous diploids constructed from haploid strains with different polymorphic tubulin genes are sporulated and the assortment of the different $\alpha$ - and B- tubulin genes amongst the resultant progeny is analysed using heterologous $\alpha$ - and $\beta$ - tubulin DNA probes. Application of this technique has established that $\underline{P}$. polycephalum contains a minimum of four $\alpha$ - and three $\beta$ - tubulin genes, an estimate which agrees well with the biochemical evidence (Burland et al., 1983; Burland et al., 1984). Furthermore, this approach has established that two loci, benA and benc which control resistance to benzimidazole compounds, code for an $\alpha$ - and a $\beta$ - tubulin respectively (Schedl et al., 1984b). As described in Chapter 1, Cabral and colleagues have isolated B- tubulin mutations in Chinese hamster ovary ( $\mathrm{CHO}$ ) cells through the isolation of mutants resistant to colchicine, colcemid or griseofulvin 
(Cabral et al., 1980). Several of these mutants also exhibit a temperature sensitive growth defect. In a subsequent study evidence was gathered that the altered $\beta$ - tubulin conferred both drug resistance and temperature sensitivity (Cabral et al., 1982). One heat sensitive CHO cell mutant, Tax-1, resistant to the microtubule stabilizing drug taxol, has been selected which exhibits an altered $\alpha$ - tubulin (Cabral et al., 1981). The heat sensitive phenotype exhibited by two of the $\beta$ - tubulin mutants ( $\mathrm{Cmd}-4$ and $\mathrm{Grs}-2$ ) and the single $\alpha$ - tubulin mutant (Tax-1) has been analysed in greater detail. All three mutants exhibit a similar conditional phenotype: at the high temperature cells arrest with a disorganised mitotic spindle, cytokinesis fails and cell death eventually ensues. From this study it can be concluded that the heat labile tubulin present in each of these mutants normally functions as an essential component of the mitotic apparatus. Keates et al. (1981) have described a colcemid resistant $\mathrm{CHO}$ cell mutant which expresses a structurally altered tubulin component. A partially purified tubulin fraction from this mutant showed reduced binding of colcemid compared to the wild type strain. This suggests that structural alterations in a tubulin manifest the drug resistant phenotype. A recent report indicates how the general approach of selecting for drug resistance may be extended to obtain mutations in other structural components of the cell. Cytochalasin B is known to inhibit actin filament polymerisation in vitro (Stebbings and Hyams, 1979; Alberts et al., 1983). Toyama and Toyama (1984) have isolated a mammalian cell mutant resistant to this compound. This mutant expresses an electrophoretically altered $\beta$ - actin polypeptide, whereas the mobility of the $\gamma$ actin species is normal. Cross resistance is also shown by the mutant to the inhibitory effects of cytochalasin $E, D$ and dihydrocytochalasin $B$. These results strongly suggest that cytochalasin 
$B$ resistance is conferred by an alteration in $\beta$ - actin. Since evicence is rapidly accumulating that microtubules and actin filaments are physically associated with each other in the cytoskeleton (Tiwari et al., 1984; Pollard et al.; 1984), the ability to isolate tubulin and actin mutations should facilitate the study of interactions between these components within the cell.

\subsection{Organisation of tubulin genes and the regulation of tubulin synthesis}

The identification of tubulin mutations has supplemented the considerable progress which has been made in the study of tuoulin genes and the regulation of their transcriptional and translational activity in a wide variety of systems. The conserved nature of tubulin, and the ability to purify tubulin from numerous taxonomic groups have been two of the key features by which the current wealth of information on the genetics and biochemistry of tubulin has been obtained.

Tubulins in most organisms exist as small multiple gene families, consisting of approximately equal numbers of $\alpha$ - and $\beta$ - tubulin genes (for concise reviews on this subject see Cleveland, 1983, and Raff, 1984). Generally, $\alpha$ - and $\beta$ - tubulin genes are dispersed throughout the genome. Two groups of parasitic protozoa provide interesting exceptions to this general rule. In trypanosomes most tubulin genes are present as tandemly repeated $[\alpha-\beta]$ gene pairs (Thomashow et al., 1983). By contrast, in Leishmania enriettii $\alpha$ - and $\beta$ - tubulin genes are clustered separately in tandem repeats (Landfear et al., 1983). As described previously, $\underline{S}$. pombe has a small multiple gene family consisting of two $\alpha$ - and one $\beta$ - tubulin genes. Biochemical and genetic evidence (Neff et al., 1983) suggests that $\underline{\underline{s}}$. cerevisiae has but one $\alpha$ - and one $\beta$ - tubulin gene. It is considered that $\alpha$ - and $\beta-$ 
tubulin genes arose early in evolution from the duplication of an ancestral tubulin sequence (Little et al., 1982). The simplistic organisation of tubulin genes in yeast, which may be considered as an archetypal arrangement, probably reflects the simple non-motile life cycle of these organisms.

In several well studied systems such as Physarum polycephalum (Burland et al., 1984), Drosophila melanogaster (Kalfayan and Wensink, 1982), Leishmania enriettii (Landfear et al., 1983) and Trypanosome sp. (Thomashow et al., 1983) transcription from the different tubulin genes is developmentally regulated. An exception is Chlamydomonas reinhardtii. In this case, transcription from the two $\alpha$ - and two $\beta-$ tubulin genes present in this organism is co-ordinately regulated (Brunke et al., 1982a). In many cases the multiplicity of tubulin genes has been correlated at the biochemical level with a multiplicity of tubulin species; indeed, most cells or tissues examined to date exhibit tubulin microheterogeneity (Raff, 1984). The 'multitubulin hypothesis' (Fulton and Lai, 1982) suggests that the different tubulin species perform different functions within the cell. The major problem in testing this hypothesis lies in estabiishing the ultimate location of the different tubulin species within the cell. However, a testis specific $\beta$ - tubulin protein (see also Chapter 1) in D. melanogaster has been identified as the sole $\beta$ - tubulin species used in the construction of the sperm axoneme (Raff, 1984). Genetical evidence indicates that, in $\underline{A}$. nidulans, the $\beta$ - tubulin protein coded by the benA gene is associated with microtubules which mediate nuclear migration and mitosis (Oakley and Morris, 1980; Oakley and Morris, 1981). Similarly, in $\underline{S}$. pombe the $\alpha$ - and $\beta$ - tubulin genes nda 2 and nda3 appear to be involved in the functioning of cytoplasmic and nuclear microtubules (Umesono et al., 1983a). Post-translational 
modification of tubulin is one mechanism which may be used by cells to ensure that certain tubulins are competent to serve specific functions. In $\underline{\mathrm{C}}$. reinhardtii for instance, $\alpha$ - tubulin destined for incorporation into the flagella is subject to post-translational modification (Brunke et al., 1982b; L'Hernault and Rosenbaum, 1983).

A number of studies have concentrated on the regulation of tubulin synthesis throughout the cell cycle. Two reports indicate that tubulin synthesis increases through the cell cycle of $\underline{\underline{C}}$. reinhardtii, reaching a peak at the time of mitosis and cell division (Piperno and Luck, 1977; Weeks and Collis, 1979). In marked contrast to these studies, Rollins et al. (1983) have shown that tubulins are synthesised continuously through the cell cycle of this organism and do not show periodic changes. The synthesis of the two $\alpha$ - and two $\beta$ - tubulin species present in the plasmodial form of $\underline{P}$. polycephalum increases during the cell cycle up to mitosis and then decreases thereafter (Schedl et al., 1984a). It has been reported that in Tetrahymena pyriformis (Bird and Zimmerman, 1981) and mammalian cells (Bravo and Celis, 1980) tubulin synthesis peaks shortly before or during mitosis. The studies described above suggest that not all organisms are likely to meet the synthetic demands of constructing a mitotic spindle from the periodic synthesis of tubulin at the time of mitosis.

\subsection{Nature of the ben $4^{+}$product}

Since it would appear unlikely that ben 4 codes for either an $\alpha$ - or a $\beta$ - tubulin, this section provides an alternative proposal for the nature of the ben $4^{+}$product. The available evidence suggests that the ben $^{+}$product is a protein which interacts with benomy 1 and which is intimately concerned with the mechanism of mitosis. In yeasts, as in other organisms, there is little information concerning 
proteins which interact with tubulin in the mitotic spindle. However, several spindle-specific proteins have been isolated and characterised from mammalian cells (Zieve and Solomon, 1982). The elegant studies of Luck and his colleagues have shown that the axonemal microtubules of the eukaryotic flagellum are associated with many other protein structures whose interactions provide the power for motility (Luck, 1984). Certainly, the successful functioning of the mitotic spindle must rely on the interaction of microtubules with a variety of accessory proteins (Vallee et al., 1984).

A class of microtubules associated proteins (MAPs) has been extensively analysed, especially those obtained from neural tissue. The MAP proteins are found to co-polymerise stoichiometrically with neural tubulin through cycles of assembly and disassembly, and may be separated from tubulin by DEAE-cellulose chromatography. A remarkable feature of MAP proteins is that they stimulate the in vitro polymerisation of neural tubulin (Vallee et al., 1984). MAP proteins isolated from neural microtubules are non-tubulin and may be resolved electrophoretically into two distinct classes. Due to their large subunit size (approximately 300,000 $\mathbf{M}_{\mathrm{r}}$ ) the most prominent class of neural MAPs are known as high molecular weight (HMW) MAPs. The second and less abundant class of MAPs have a much smaller molecular weight (approximately $\left.60,000 \sqrt[q_{i}]{ }\right)$ and are designated taul MAPs (Vallee et al., 1984). The HMW MAPs may be resolved further into two classes, designated MAP 1 and MAP 2. Both MAP 1 and MAP 2 stimulate the assembly of neural tubulin and are found to decorate the surface of microtubules in a regular pattern of arm-like projections (Stebbings and Hyams, 1979; Vallee et al., 1984). Purified MAP 2 protein is associated with the catalytic and regulatory subunits of a cyclic AMP dependent protein kinase (Theurkauf and Vallee, 1982). For this reason it has 
been demonstrated that MAP 2 may become heavily phosphorylated in vitro (Vallee et al., 1984). The extent of MAP 2 phosphorylation is considered to regulate the in vitro interaction of MAP 2 with microtubules and actin filaments (Pollard et al., 1984). However, MAP 2 appears to be limited in its distribution to the neural tissue of vertebrates. MAP 1 does not become phosphorylated in vitro but nevertheless appears to be more widely distributed amongst different cell types (Shulman, 1984; Vallee et al., 1984). Of particular interest in that MAP 1 and other MAP-like proteins have been localised in the mitotic spindle of several cell systems (Izant et al., 1983; Vallee and Bloom, 1983). In this respect, it is significant that bridging components have been identified which apparently cross link microtubules in the mitotic apparatus (Fuge, 1974). The existence of MAPs in lower eukaryotes has recently been confirmed. A MAP fraction from Physarum polycephalum was found to stimulate the in vitro assembly of tubulin from this organism (Roobol et al., 1980a). In this case the MAP fraction was found to comprise three protein species with molecular weights of 49,000, 57,000 and 59,000. MAP-Iike proteins have also been identified in the yeasts $\underline{S}$. cerevisiae (Clayton et $\underline{\text { al. }}$, 1979) and $\underline{\mathrm{S}}$. pombe (Toda et al, 1984; M. Yaragida, personal communication).

These findings lead to the proposition that ben 4 codes for a MAP protein. This in turn poses the important question: could an alteration in a MAP protein (i.e. the proposed ben 4 gene product) possibly confer a benomyl resistant cold sensitive cdc phenotype? Circumstantial evidence indicates that this may very well be possible. Roobol et al. (1980a) report that a deficiency of MAPs in an in vitro assembly system leads to increased cold lability of microtubules. It is conceivable that a structural alteration in a MAP protein 
may induce a similar response. An altered MAP protein may well mask drug binding sites on the tubulin subunit, thereby conferring increased resistance to antimicrotubule agents. Support for this comes from two independent reports which show that MAP proteins compete for the colchicine binding site on the tubulin dimer (Wiche and Furtner, 1980; Nunez et al., 1979). Indeed, MAPs are known to be the target site for the antimitotic agent griseofulvin (Roobol et al, 1977). On the basis of this evidence it would seem reasonable to speculate that ben 4 codes for a MAP protein.

\subsection{Conclusion}

The study of mitosis is moving into a new and exciting era with the advent of a range of powerful genetical, biochemical and cytological experimental approaches with which to analyse the process. It is likely that cde mitotic mutants of microbial eukaryotes, especially yeast, will play a key role in the elucidation of the structural and controlling elements which contribute to the mechanism of mitosis.

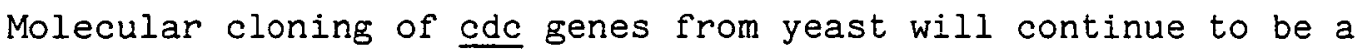
necessary first step in the elucidation of their cellular function. In this way, the product of the $\underline{c^{2}} 2$ gene of $\underline{S}$. pombe, a product which is functionally required during $G 1$ and at the commencement of mitosis, has recently been identified as a protein with homology to bovine cyclic AMP dependent protein kinase and also to the protein kinase like products which are coded by src oncogenes (Hindley and Phear, 1984; Beach et al., 1982).

It is likely that the identification of a range of proteins which interact with microtubules will be possible through the isolation of extragenic suppressors which modify the conditional cdc phenotype conferred by certain $\alpha$ - and $\beta$ - tubulin mutations. Evidence has been 
gathered here that the ben 4 gene of $\underline{S}$. pombe may code for a microtubule associated protein. Recent advances in the purification of tubulin and MAP proteins from lower elkaryotes will assist in the identification of additional components of the mitotic apparatus (Kilmartin, 1981; Roobol et al., 1980a). In this respect, the biochemical and genetic analysis of the eukaryotic flagellum is well advanced (Luck, 1984). The study of mitosis in all systems would certainly be enhanced by a full biochemical description of proteins specifically associated with the mitotic apparatus. Some progress has already been made in this direction (Kilmartin and Fogg, 1983; Zieve and Solomon, 1982; Gull, 1981).

A full description of mitosis will only come about from a fusion of the experimental approaches described above. It is to be hoped that further analysis of ben 4 mutants, and the identification of the ben $4^{+}$gene product will assist in this. 


\section{ACRNOWLEDGEMENTS}

I should like to thank my supervisor Dr. Peter Fantes for his constant advice and encouragement during the course of this project. Many thanks are also due to Professor J. M. Mitchison for helpful discussion, advice and encouragement.

I should like to acknowledge the invaluable assistance given at various times by $\mathrm{Dr}$. Jim Creanor of this department, and Dr. Chris Jeffree of the Botany department Electron Microscopy Unit.

My thanks go as well to the members of the 3 rd and 4 th floors of the Zoology department, particularly Colin Gordon, Dave Hughes and Dr. Stuart Smith, for contributing to such a pleasant working environment.

I am most grateful to Lucian Begg for typing this thesis so expertly.

Finally, special thanks go to my wife Lorraine for all her support and encouragement. 


\section{BIBLIOGRAPHY}

ADAMS, A. E. M., and PRINGLE, J. R. (1984). J. Cell Biol. 98, 934-945. AIST, J. R., and BERNS, M. W. (1981). J. Cell Biol. 91,446-459. AIST, J. R. and WILliAMS, P. H. (1972). J. Cell Biol. 55, 368-389. ALBERTS, B., BRAY, D., LEWIS, J., RAFF, M., ROBERTS, K., and WATSON, J. D. (1983). Molecular Biology of the Cell. Garland Publishing Inc. 1983.

AMBROSE, E. J., and EASTY, D. M. (1970). Cell Biology. Thos. Nelson, London 1970.

ARES, M. Jr., and HOWELL, S. H. (1982). Proc. Natl. Acad. Sci. USA. $\underline{79}, 5577-5581$.

BAUER, W. and VINOGRAD, J. (1968). J. Mol. Biol. 33, 141-171. BAUM, P., THORNER, J., and HONIG, L. (1978). Proc. Natl. Acad.

Sci. USA. 75, 4962-4966.

BEACH, D., DURKACZ, B., and NURSE, P. (1982). Nature 300,706-709. BEACH, D., and NURSE, P. (1981). Nature 290,140-142. BIBRINC, T., BAXANDALL, J., DENSLOW, S. and WALKER, B. (1976).

J. Cell. Biol. 69,301-312.

BIRD, R. G., and ZIMMERMAN, A. M. (1981). Can. J. Biochem. 59,937-943. BIRNBOIM, H. C., and DOLY, J. (1979). Nucleic Acids Res. I, 1513-1523. BOLLEN, D. J., and FUCHS, A. (1970). Neth. J. Plant Pathol. 76, 299-312.

BORISY, G. G., and TAYLOR, E. W. (1967a). J. Cell Biol. 34, 525-33. BORISY, G. G., and TAYLOR, E.W. (1967b). J. Cell Biol. 34, 535-48. BOTSTEIN, D., and MAURER, R. (1982). Ann. Rev. Genetics 16, 61-83. BRAvo, R., and CELIS, J. E. (1980). J. Cell Biol. 84, 795-802. BRUNKE, K. J., YOUNG, E. E., BUCHBINDER, B. U., and WEEKS, D. P. (1982a). Nucleic Acids Res. 10, 1295-1310.

BRUNKE, K., COLLIS, P., and WEEKS, D. P. (1982b). Nature 297, 516-518. BURLAND, T. G., GULL, K., SCHEDL, T., BOSTON, R. S., and DOVE, W. F. (1983). J. Cell Biol. 97, 1852-1859.

BURLAND, T. G., SCHEDL, T., GULL, K., and DOVE, W. F. (1984). Genetics 108, 123-141.

BURNS, R. G. (1973). Expl. Cell Res. 81, 285-292.

BYERS, B. (1981). In: Molecular genetics in yeast ( $D$. von Wettstein, J. Frus, M. Kielland-Brand, A. Stenderup, Eds.), pp. 119-131, Munksgaard Copenhagen, 1981.

BYERS, B., and GOETSTCH, L. (1975). J. Bact. 124, 511-523. 
CABRAL, F., ABRAHAM, I., and GOTTESMAN, M. M. (1981). Proc. Natl. Acad. Sci. 78, 4388-4391.

CABRAL, F., ABRAHAM, I., and GOTTESMAN, M. M. (1982). Mol. Cell Biol. 2, 720-729.

CABRAL, F., SOBEL, M. E., and GOTTESMAN, M. M. (1980). Cell 20 , 29-36.

CIFEELli, A. (1983). B.Sc. Honours Thesis, Zoology Department, Edinburgh University.

CLAYTON, L., and LLOYD, C. W. (1984). Eur. J. Cell Biol. 34, 248-253. CLAYTON, L., POGSON, C. I., and GULL, K. (1979). Febs. Letters $106,67-70$.

CLEMONS, G. P., and SISLER, H. D. (1969). Phytopathology 59, 705-706. CLEMONS, G. P., and SISLER, H. D. (1971). Pestic. Biochem. Physiol. 1, 32-43.

Cleveland, D. W. (1983). Cell 34, 330-332.

COLLIS, P. S., and WEEKS, D. P. (1978). Science 202, 440-442.

COSS, R. A., BLOODGOOD, R. A., BROWER, D. L., PICKETT-HEAPS, J. D., and McINTOSH, J.R. (1975). Expl. Cell Res. 92, 394-398.

CREANOR, J., MAY, J. W., and MITCHISON, J. M. (1975). Evr. J. Biochem. 60, $487-493$.

CROUZET, M., and BEGUERET, T. (1978). Mol. Gen. Genet. 165, 283-288. DAGERT, M. , and EHRLICH, S. D. (1979). Gene $\underline{6}, 23-28$.

DAVIDSE, L. C. (1975). In Microtubules and microtubule inhibitors

(M. Borgers and M. De Brabander, Eds.), pp. 483-495. North Holland Publishing Co. Amsterdam, 1975.

DAVIDSE, L. C. (1976). Pestic. Biochem. Physiol. 6 , 538-546.

DAVIDSE, L. C., and FLACH, W. (1977). J. Cell Biol 72, 174-193.

DAVIDSE, L. C., and FLACH, W. (1978). Biochim. Biophys. Acts 543, 82-90.

DYSON, R. D. (1974). Cell Biology: A Molecular Approach. Allyn and Bacon Inc., 1974.

FALKE, E., and WRIGHT, T. (1975). Genetics 81, 655-682.

FANTES, P. A. (1979). Nature 279 , 428-430.

FANTES, P. A. (1982). J. Cell Sci. 55, 383-402.

FILETICI, P., and BALLARIO, P. (1984). Abstract, XII International conference on Yeast Genetics and Molecular Biology. Edinburgh, (1984).

FOGEL, S., and WELCH, J. W. (1982). Proc. Natl. Acad. Sci. USA 79 , 5342-5346.

FUGE, H. (1974). Protoplasma 82, 289-320. 
FUGE, H. (1977). Int. Rev. Cytol. (Supplement 6), 1-58.

FULTON, C., and LAI, E. Y. (1982). In Microtubules in Microorganisms

(P. Cappacinelli and N. R. Morris, Eds.), pp. 235-273. Marcel

Dekker, New York, 1982.

GAMBINO, J., BERGEN, L. G., and MORRIS, N. R. (1984). J. Cell Biol. 99, 830-838.

GEORGOPOULOS, S. G. (1975). Proc. Soc. Gen. Microbiol. 4, 59-60. GRUNSTEIN, M., and HOGNESS, D. S. (1975). Proc. Natl. Acad. Sci. USA $\underline{72}, 3961-3965$.

GULL, K., and TRINCI, A. D. J. (1973). Nature 244, 292-293.

GUTHRIE, C., NASHIMOTO, H., and NOMURA, M. (1969). Proc. Natl.

Acad. Sci. USA 63, 384-391.

GUTZ, H., HESLOT,.H., LEUPOLD, U., and LOPRIENO, N. (1974). In

Handbook of Genetics, Vol. I (R. C. King, Ed.), pp. 395-446.

Plenum Press, New York, 1974.

HABER, J. E., DELOQUIN, J. G., HALVORSON, H. O., and BORISY, G. G.

(1972). J. Cell Biol. 55, 355-367.

HAMMERSCHLAG, R., and SISLER, H. (1973). Pestic. Biochem. and Physiol.

3, $42-54$.

HARTWELL, L. H. (1978). J. Cell Biol. 77, 627-637.

HASTIE, A. C. (1970). Nature $\underline{226}, 771$.

HEATH, I. B. (1981). In The Fungal Nucleus (K. Gull and S. G. Oliver,

Eds.), pp. 85-112. Cambridge University Press, 1981.

HEPLER, P. K., and JACKSON, W. T. (1969). J. Cell Sci. 5, 727-743.

HEREWARD, F. V. (1974). Planta 117, 355-360.

HERMAN, I. M., and POLLARD, T. D. (1978). Exp. Cell Res. 114, 15-25.

HINDLEY, J., and PHEAR, G. (1984). Gene 31, 129-134.

HIRAOKA, Y., TODA, T., and YANAGIDA, M. (1984). Cell 39, 349-358.

HIRATA, A., and TANAKA, K. (1982). J. Gen. Appl. Microbiol. 28, 263-274.

HOEBEKE, G., VAN NIJEN, G., and DE BRABANDER, M. (1976). Biochem.

Biophys. Res. Commun. $\underline{69}, 319-324$.

HOWARD, R. J., and AIST, J. R. (1980). J. Cell Biol. 87, 55-64. IBRAHIM, M. A. K., and CODDINGTON, A. (1976). Heredity 37, 179-191. INOUÉ, S. (1953). Chromosoma $\underline{5}$, 487-500.

INOUÉ, S. (1964). In Primitive Motile Systems in Cell Biology (R. D.

Allen and N. Kamiya, Eds.), pp. 549-598. Academic Press, New York, 1964. 
INOUÉ, S. (1982). In Developmental Order: its Origin and Regulation

(P. B. Green, Ed.), pp. 35-76. AR Liss Inc. New York, 1982.

INOUE, S., and SATO, H. (1967). J. Cen. Physiol. 50, 259-92.

IRELAND, C. M., GULL, K., GUTTERIDGE, W. E., and ROGSON, C. I. (1979).

Biochemical Pharmacology 28, 2680-2682.

IZANT, J. G., WEATHERBEE, J.A., and McINTOSH, J. R. (1983). J.

Cell Biol. 96, 424-434.

JACOBS, M. (1979). In Microtubules (K. Roberts and J. S. Hyams, Eds.), pp. 255-275. Academic Press, New York, 1979.

JACOBS, C. W., and SZANISZLO, P. J. (1982). Archives of Microbiology $133,155-161$.

JARVIK, J., and BOTSTEIN, D. (1973). Proc. Natl. Acad. Sci. USA 70, 2046-2050.

JARVIK, K. J., and BOTSTEIN, D. (1975). Proc. Natl. Acad. Sci. USA 72, 2738-2742.

JOHN, P. C. L. (1981). The Cell Cycle. Cambridge University Press, 1981 .

JOHNSON, B. F., CALLEJA, G. B., YOO, B. Y., ZUCKER, M., and MCDONALD,

I. J. (1982). Int. Rev. Cytol. 75, 167-208.

JOHNSTON, P. A., and CODDINGTON, A. (1983). Curr. Genetics I, 299-307.

KAFATOS, F. C., WELDON JONES, C., and EFSTRATIADIS, A. (1979).

Nucleic Acids Res. I, 154-1552.

KALFAYAN, L., and WENSINK, P. C. (1981). Cell 24, 97-106.

KALFAYAN, L., and WENSINK, P. C. (1982). Cell 29, 91-98.

KEATES, R. A. B., SARANGI, F., and LING, V. (1981). Proc. Natl.

Acad. Sci. USA 78, 5638-5642.

KEMPHUES, K. J., RAFF, R. A., KAUFMAN, T. C., and RAFF, E. C. (1979).

Proc. Natl. Acad. Sci. USA 76, 3991-3995.

KEMPHUES, K. J., RAFF, E. C., RAFF, R. A., and KAUFMAN, T. C. (1980).

Cell 21, 445-451.

KILMARTIN, J. V. (1981). Biochemistry 20, 3629-3633.

KILMARTIN, J. V., and ADAMS, A. E. M. (1984). J. Cell Biol. 98, 922-933.

KILMARTIN, J. V., and FOGG, J. (1982). In Microtubules in Micro-

organisms (P. Cappuccinelli and N. R. Morris, Eds.), pp. 157-170. Marcel Dekker, New York, 1982.

KILMARTIN, J. V., WRIGHT, B., and MILSTEIN, C. (1982). J. Cell Biol. 93, 576-582. 
KING, S. M., and HYAMS, J. (1982). Protoplasma 110, 54-62.

KOHLI, J., HOTTINGER, H., MUNZ, P., STRAUSS, A., and THURIAUX, P.

(1979). Genetics 87, 471-489.

KORNBERG, A. (1975). DNA Replication. W. H. Freeman and Co., San

Francisco, 1975.

KUBAI, D. F. (1975). Int. Rev. Cytol. 쏘, 167-227.

KUROIWA, T., KOJIMA, H., MIYAKAWA, I., and SANDO, N. (1984). Expl.

Cell Res. 153, 259-265.

LANDFEAR, S. M., McMAHON-PRATT, D., and WIRTH, D. F. (1983). Molec.

Cell Biol. $\underline{3}, 1070-1076$.

LEDERBERG, S., and STETTEN, G. (1970). Science 168, 485-487.

LEHNINGER, A. (1975). Biochemistry 2nd Edition, Worth Publishers, 1975.

LEIBOWITZ, P. J., and SCHAECHTER, M. (1975). Int. Rev. Cytol. 41, $1-28$.

LEUPOLD, U. (1950). C.R. Lab. Carlsberg, Ser. Physiol. 24, 381-480.

(Quoted in Nurse et al., 1976).

L'HERnAUlT, S. W., and ROSEnBAUM, J. L. (1983). J. Cell Biol. 97 , $258-263$.

LING, V. (1977). J. Cell Physiol. 91, 209-224.

LITTLE, M., KRAUHS, E., PONSTINGL, H., LUDUENA, R., and RICE, N.

(1982). In: Microtubules in Microorganisms (P. Cappiccinelli

and N. R. Morris, Eds.), pp. 1-14. Marcel Dekker, New York, 1982. LOSSON, R., and LACROUTE, F. (1983). Cell 32, 371-377.

LUCK, D. J. L. (1984). J. Cell Biol. 98, 789-794.

LUDUENA, R. F. (1979). In: Microtubules (K. Roberts and J. S. Hyams,

Eds.), pp. 66-115. Academic Press, New York, 1979.

LUDUENA, R. F., and WOODWARD, D. O. (1973). Proc. Natl. Acad. Sci. USA $70,3594-3598$.

MANIATIS, T., FRITSCH, E. F., and SAMBROOK, J. (1982). Molecular Cloning, a Laboratory Manual. Cold Spring Harbor Laboratory, 1982.

MAZIA, D., SChATTEN, G., and SALE, W. (1975). J. Cell Biol. 66, $198-200$.

McCULLY, E. K., and ROBINOW, C. F. (1971). J. Cell Sci. 9, 475-507. MITCHISON, J. M. (1970). In: Methods in Cell Physiology (D. M.

Prescott, Ed.), Vol. IV, pp. 131-165. Academic Press, New York, 1970. 
MITCHISON, J. M. (1971). The Biology of the Cell Cycle. Cambridge

University Press, 1971.

MITCHISON, J. M. (1977). In: Mitosis: Facts and Questions (M. Little,

N. Paweletz, C. Petzelt, H. Ponstingl, D. Schroeter, H.-P.

Zimmerman, Eds.), pp. 1-19. Springer-Verlag, 1977.

MITCHISON, J. M., and CREANOR, J. (1971). Expl. Cell Res. 67, 368-374. MOIR, D., and BOTSTEIN, D. (1982). Genetics 100, 565-577.

MOIR, D., STEWART, S. E., OSMOND, B. C., and BOTSTEIN, D. (1982).

Genetics 100, 547-563.

MORRIS, N. R. (1980). In: The Eukaryotic Microbial Cell (G. W.

Gooday, D. Lloyd and A. P. J. Trinci, Eds.), pp. 41-76. Cambridge University Press, 1980.

MORRIS, N. R., LAI, M. H., and OAKLEY, C. E. (1979). CelI 16, 437-442. NACHMIAS, A., and BARASH, I. (1976). J. Gen. Microbiol. 94, 167-172. NASMYTH, K, and NURSE, P. (1981). Molec. Gen. Genet. 182, 119-124. NEFF, N. F., THOMAS, J. H., CRISAFI, P., and BOTSTEIN, D. (1983).

Cell 33, 211-219.

NUNEZ, J., FELLOWS, A., FRANCON, J., and LENNON, A. M. (1979).

Proc. Nat1. Acad. Sci. USA 76, 86-90.

NURSE, P. (1975). Nature 256, 547-551.

NURSE, P., THURIAUX, P., and NASMYTH, K. (1976). Mol. Gen. Genet.

$146,167-178$.

OAKLEY, B. R. (1981). In: Cellular Dynamics: Mitosis/Cytokinesis,

pp. 181-196. Academic Press, New York, 1981.

OAKLEY, B. R., and MORRIS, N. R. (1980). Cel1 19, 255-262.

OAKLEY, B. R., and MORRIS, N. R. (1981). Cell 24 , 837-845.

OLIVER, J. M., KRAWIEC, J. A., and BERLIN, R: D. (1978). Expl.

Cell Res. 116, 229-237.

ORR, E., and ROSENBERGER, R. F. (1976). J. Bact. 126, 903-906.

ORR-WEAVER, T. L., SZOSTAK, J. W., and ROTHSTEIN, R. J. (1981).

Proc. Nat1. Acad. Sci. USA 78, 635-6358.

PETERSON, J. B., and RIS, H. (1976). J. Cell Sci. 22, 219-42.

PETZELT, T. C. (1979). Int. Rev. Cytol. 60, 53-102.

PICKETT-HEAPS, J. D., TIPPIT, D. H., and PORTER, K. R. (1982).

Cell 29, 729-744.

PIPERNO, G., and LUCK, D. J. L. (1977). J. Biol. Chem. 252, 383-391.

POLANSHEK, M. M. (1977). J. Cell Sci. 23, 1-23.

POLLARD, T. D., SELDEN, S. C., and MAUPIN, D. (1984). J. Cell Biol.

$\underline{99}, 33 \mathrm{~s}-37 \mathrm{~s}$. 
PONSTINGL, H., KRAUHS, E., LITTLE, M., KEUPF, R., HOFER-WARBINKE, A., and ADE, W. (1981). In: Cold Spring Harbor Symposia on Quantitative Biology Volume XLVI, pp. 191-197. Cold Spring Harbor, 1981.

PONSTINGL, H. M., LITTLE, M., KRAUHS, E., and KEMPF, T. (1979). Nature 282, 423-424.

PRATT, M. M., OTTER, T., and SALMON, E. D. (1980). J. Cell Biol. $\underline{86}$, $738-745$.

PRINGLE, J.R. (1978). J. Cell Physiol. 95, 393-406.

PRINGLE, J. R., and HARTWELL, L. H. (1981). In: The Molecular Biology of the Yeast Saccharomyces: Vol. I Life Cycle and Inheritance (E. N. Strathern, E. W. Jones, J. R. Broach, Eds.), pp. 97-142. Cold Spring Harbor, 1981.

PRINGLE, J.R., ROBINSON, J. S., EVANS, C. T., JACOBS, C. W., STAPLETON, A., HAARER, B., PRESTON, R. SHIELS, P., and BLOOM, L. (1984). Abstract XII International Conference on Yeast Genetics and Molecular Biology. Edinburgh (1984).

QUINLAN, R. A., POGSON, G. I., and GULL, K. (1980). J. Cell Sci. 46 , $341-352$.

RAFF, E. C. (1984). J. Cell Biol. 99, 1-10.

REYNOLDS, E. S. (1963). J. Cell Biol. 17, 208-212.

RIGBY, P. W. J., DIECKMANN, M., RHODES, C., and BERG, P. (1977).

J. Mol. Biol. 113, 237-251.

RIS, H. (1975). Bio Systems I, 298-304.

ROBINOW, C. F. (1977). Genetics 87, $491-497$.

ROBINOW, C.F., and MARAK, J. (1966). J. Cell Biol. 29, 129.

ROLLINS, M. J., HARPER, J. D. I., and JOHN, P. C. L. (1983). J. Gen.

Microbiol. 129, 1899-1919.

ROOBOL, A., GULL, K., and POGSON, C. I. (1977). Febs. Letters 75 , 149-153.

ROOBOL, A., POGSON, C. I., and GULL, K. (1980a). Expl. Cell Res. 129, $455-467$.

ROOBOL, A., POGSON, C. I., and GULL, K. (1980b). Biochem, J. 189, 305-312.

ROTH, L. E. (1967). J. Cell Biol. 34, 47-59.

RUCKLIDGE, R. A. (1977). 'Verticillium': U.K. Mushroom Industry Conference, Jersey, pp. 106-114.

SANGER, J. W. (1975). Proc. Natl. Acad. Sci. 72, 2451-2455. 
SATO, C. H. (1976). Expl. Cell Res. 101, 251-259.

SCHEDL, T., BURLAND, T. G., GULL, K., and DOVE, W. F. (1984a).

J. Cell Biol. 99, 155-165.

SCHEDL, T., OWENS, J., DOVE, W. F., and BURLAND, T. G. (1984b). Genetics 108, 143-164.

SCHULMAN, H. (1984). Molec. Cell Biol. 4, 1175-1178.

SHEIR-NEISS, G., LAI, M., and MORRIS, N. R. (1978). Cell 15, 638-47.

SHEIR-NEISS, G., NARDI, R. B., GEALT, M. A., and MORRIS, N. R. (1976).

Biochem. Biophys. Res. Commun. 69, 285-290.

SILFLOW, C. D., and ROSENBAUM, J. L. (1981). Cell 24, 81-88.

SIMCHEN, G. (1978). Ann. Rev. Genetics 12, 161-191.

SINGH, A., MASON, T., and ZIMMERMAN, R. (1978). Molec. Gen. Genet. $161,143-151$.

SMITH, H. O. (1980). Methods in Enzymology 65, 371-80.

SOUTHERN, E. M. (1975). J. Mol. Biol. $\underline{98}$, 503-517.

SPURR, A. R. (1969). J. Ultrastructure Research 26, 31-43.

STEBBINGS, H., and HYAMS, J.S. (1979). Cell Motility, Longman

Press, 1979.

STREIBLOVA, E., HASEK, J., and JELKE, E. (1984). J. Cell Sci. 69, 47-65.

STREIBLOVA, E., and NURSE, P. (1984). The Microbial Cell Cycle.

CRC Press Inc., Florida, 1984.

TAKAHASHI, T., and SATO, H. (1982). Cell Structure and Function I, 349-357.

TASH, J. S., WELSH, M. J., and MEANS, A. R. (1980). Cel1 21, 57-65. THERKAUF, W. E., and VALLEE, R. B. (1982). J. Biol. Chem. 257,

3284-3290.

THOMASHOW, L. S., MILHAUSEN, M., RUTTER, W. J., and AGABIAN, N.

(1983). Cell 32, 35-43.

THURIAUX, P., NURSE, P., and CARTER, B. (1978). Molec. Gen. Genet. $161,215-220$.

THURING, R. W. J., SANDERS, J. P. M., and BORST, P. (1975).

Analytical Biochemistry 66, 213-220.

TIWARI, S. C., WICK, S. M., WILLIAMSON, R. E., and GUNNING, B. (1984).

J. Cell Biol. 99, 63s-69s.

TODA, T., ADACHI, Y., HIRAOKA, Y., and YANAGIDA, M. (1984). Cell $\underline{34}$, 233-242.

TODA, T., UMESONO, K., HIRATA, A., and YANAGIDA, M. (1983). J. Mol. Biol. 168, 251-270. 
TODA, T., YAMAMOTO, M., and YANAGIDA, M. (1981). J. Cell Sci. $\underline{\text { 2, }}$ $271-287$.

TOYAMA, S., and TOYAMA, S. (1984). Cell $\underline{37}, 609-614$.

UMESONO, K., HIRAOKA, Y., TODA, T., and YANAGIDA, M. (1983b). Curr.

Genetics I, 123-128.

UMESONO, K., TODA, T., HAYASHI, S., and YANAGIDA, M. (1983a). J. MoI. Biol. 168, 271-284.

UPSHALL, A., GIDDINGS, B., and MORTIMORE, I. D. (1977). J. Gen.

Microbiol. 100, 413-418.

VALENZUELA, P., QUIROGA, M. , ZALDIVAR, J., RUTTER, W., KIRSCHNER, M.W., and CLEVELAND, D. W. (1981). Nature 289, 650-655.

VALLEE, E. B., and BLOOM, G. S. (1983). Proc. Natl. Acad. Sci. USA $80,6259-6263$.

VALLEE, R. B., BLOOM, G. S., and THEURKAUF, W. E. (1984). J. Cell Biol. $\underline{99}, 38 \mathrm{~s}-44 \mathrm{~s}$.

VAN TUYL, J. (1974). Neth. J. Plant Pathol. 80, 165-168.

WALDRON, C., and ROBERTS, C. F. (1974). Mol. Gen. Genet. 134, 115-132. WALKER, G. M. (1982). J. Gen. Microbiol. 128, 61-71.

WATER, R., and KLEINSMITH, L. (1976). Biochem. Biophys. Rẹs. Commun. 70, 704-708.

WATSON, J. D. (1977). Molecular Biology of the Gene (3rd Ed.). Addison-Wesley, 1977.

WEEKS, D. P., and COLLIS, P. S. (1979). Dev. Biol. 69, 400-407. WEISENBERG, R. C. (1972). Science 177, 1104-5.

WELSH, M. J., PEDMAN, J. R., BRINKLEY, B. R., and MEANS, A. R. (1978).

Proc. Natl. Acad. Sci. USA 75, 1867-1871.

WICHE, G., and FURTNER, R. (1980). Febs. Letters 116, 247-250.

WILLIAMSON, D. H., and FENNEL, D. J. (1975). In: Methods in Cell

Biology: Vol. XII (D. M. Prescott, Ed.), pp. 335-351. Academic

Press, 1975.

WOOD, J. S., and HARTWELL, L. H. (1982). J. Cell Biol. 94, 718-726.

yAMAMOTO, M. (1980). Molec. Gen. Genet. 180, 231-234.

ZICKLER, D. C. (1981). In: The Fungal Nucleus (K. Gull and S. G.

Oliver, Eds.), pp. 63-83. Cambridge University Press, 1981.

ZIEVE, G., and SOLOMON, F. (1982). Cell 28, 233-242.

Addenda

BOLLEN, J.(1971). Neth. J. Plant Pathol 17, 187-193.

GULI, K. (1981). In: The Fungal Nucleus, (K.Guli and S.G.Oliver, Eds.), pp 111-132. Cambridge University Press,' (1981).

GYGAX, K. and THURIAUX, P. (1984). current Gonetics $8,85-92$. 


\title{
Benomyl Resistant Mutants of Schizosaccharomyces pombe Cold-Sensitive for Mitosis
}

\author{
Douglas Roy and Peter A. Fantes \\ Department of Zoology, University of Edinburgh, Edinburgh, EH9 3JT, UK
}

Summary. We have isolated 150 benomyl resistant mutants of the fission yeast Schizosaccharomyces pombe. Seven of these mutants were found to be cold sensitive for mitosis. These mutants were the subject of physiological, cytological and genetical characterisation. Growth and division of the seven mutants were similar to the wild type strain at $35^{\circ} \mathrm{C}$. After shift from the permissive $\left(35^{\circ} \mathrm{C}\right)$ to the restrictive temperature $\left(20^{\circ} \mathrm{C}\right)$ the mutants became blocked in mitosis whilst cellular growth continued. Consequently, elongate cells were formed. Six of the seven benomyl resistant mutants became blocked in mitosis at $20^{\circ} \mathrm{C}$ with a single aberrant nucleus. In every case the benomyl resistant and cold sensitive phenotype was due to a mutation in a single nuclear gene. These mutants were found to comprise a single genetic linkage group (ben4) and were unlinked to existing TBZ/MBC resistant mutants of $S$. pombe. Whilst no cross resistance was found in our mutants to TBZ, six of the seven mutants were super sensitive to the spindle poison CIPC. We believe that the phenotype exhibited by these mutants is consistent with a defective tubulin subunit.

Key words: Benomyl resistance - Yeast - Mitosis - Cell cycle mutants

\section{Introduction}

In recent years a genetical approach has been successfully used to examine the control and ordering of events in the eukaryotic and prokaryotic cell cycles (Nurse 1981; Simchen 1978). Mutants conditionally blocked at specif-

Offprint requests to: $\mathrm{D}$. Roy ic points in the cell division cycle have been isolated, usually as temperature sensitive lethals. In such mutants cell cycle progress and division are blocked but growth may continue after shift from permissive to restrictive temperature.

Collections of temperature sensitive mutants defective in genes responsible for controlling the cell division cycle have been isolated from a number of microbial eukaryotes, most notably Aspergillus nidulans (Morris 1980), and the yeasts Saccharomyces cerevisiae (Hartwell 1978) and Schizosaccharomyces pombe (Nurse et al. 1976). A number of such mutants are also available in Chlamydomonas reinhardii (Howell 1974), Paramecium tetraaurelia (Peterson and Berger 1976) and Tetrahymena pyriformis (Frankel et al. 1976).

Most of these mutants have been isolated as heat sensitive lethals. However the isolation of cold-sensitive mutants (Moir et al. 1978; Toda et al. 1981) should be useful in a number of ways. For instance, the construction of double mutants carrying temperature sensitive and cold sensitive $c d c$ mutations can be used for the precise ordering of cell cycle events (Jarvik and Botstein 1973). Also, cold sensitive mutations are useful for studying self assembly events such as microtubule formation. Indeed, microtubule assembly from tubulin subunits has already been shown to be a cold sensitive process in vitro and in vivo (Weisenberg 1972; Inoué and Sato 1967; Roth 1967).

Several of the benzimidazole carbamate drugs are known to inhibit mitosis in fungi (Quinlan et al. 1980; Fantes 1982; Walker 1982). It has been shown that in benomyl resistant strains of Aspergillus nidulans resistance can be attributed to an altered $\beta$-tubulin subunit (Sheir-Neiss et al. 1978). In the light of such results we have undertaken the isolation of benomyl resistant mutants of the fission yeast $S$. pombe. In this way it was likely that a proportion of benomyl resistant mutants 
selected would contain an altered tubulin subunit by analogy with the ben A mutants of $A$. nidulans (Morris 1980). In turn, a number of such mutants might be expected to exhibit a cold sensitive nuclear division defect.

We report here on the successful isolation and preliminary characterization of mutants of this sort.

\section{Materials and Methods}

Strains and Genetic Analysis. Standard genetical procedures as described by Gutz et al. (1974) were used throughout. All mutants were isolated from a wild type strain 972 with $h^{-}$mating type as originally described by Leupold (1950). This strain was also used as a wild type control in physiological experiments. The wild type strain 975 with $h^{+}$mating type was used only for genetical analy ses.

Stable diploid strains for dominance tests were constructed using the mating type allele mat 2.102 (mei1.102) as described by Egel (1973). Haploid strains were constructed carrying the alleles to be tested in either a ade $6.704 h^{-}$or a ura5.294 mat 2.102 genetic background. Strains carrying these complementary markers were mated and the mating mixture streaked onto minimal medium and incubated at $35{ }^{\circ} \mathrm{C}$, thus selecting for prototrophic stable diploids.

The TBZ/MBC resistant strains JY16, 30 and 25 , carrying representative alleles of the genes ben 1,2 and 3 respectively (Yamamoto 1980) were kindly supplied by M. Yamamoto. The relative levels of resistance to benomyl (or its active ingredient, $\mathrm{MBC}$ ) and TBZ described by Yamamoto (1980) were confirmed in our study. However the absolute resistance levels of wild-ty pe and mutant strains were somewhat different: compare our Table 2 with Table 1 in Yamamoto (1980). The differences may be due to a combination of three factors. The ben 1,2 and 3 mutant alleles supplied by Dr. Yamamoto were not described in his original report; trace impurities in the drugs used may have had a significant effect; and our growth tests were routinely done on minimal medium, while Yamamoto (1980) used complex medium, YPD. We found the ben 2 and ben 3 mutant strains to show greater resistance to TBZ when grown on YPD than EMM. In particular it was much easier to distinguish ben 2 or ben 3 strains from ben ${ }^{+}$if YPD with TBZ included at $50 \mu \mathrm{g} / \mathrm{ml}$ was used. Therefore the segregants of crosses between ben 4 and ben 2 or ben 3 were tested for $\mathrm{TBZ}$ resistance on YPD.

Media and Growth Conditions. All work involving temperature shifts was carried out in Edinburgh Minimal Medium (EMM2; Mitchinson 1970) as modified by Nurse (1975). 2\% agar was included for solid media. For the selection of benomyl resistant mutants solid EMM2 containing $30 \mu \mathrm{g} / \mathrm{ml}$ of benomyl (methyl 1-(butylcarbamoyl)-benzimidazole-2-yl-carbamate), a gift from Du Pont de Nemours \& Co. was used. The drug was maintained as a $5 \mathrm{mg} / \mathrm{ml}$ stock solution in analytical grade ethanol.

Cultures were grown at $35^{\circ} \mathrm{C}$ and $20^{\circ} \mathrm{C}$ in flasks in shaking water baths. Temperature shifts were carried out by transferring a part of the culture from $35^{\circ} \mathrm{C}$ to $20^{\circ} \mathrm{C}$.

The drugs TBZ (Thiabendazole, a gift, Merck, Sharp and Dohme Ltd.) and CIPC (Isopropyl N-(3-chlorophenyl) carbamate; Sigma) were also maintained as $5 \mathrm{mg} / \mathrm{ml}$ stock solutions in ethanol and were added to the media prior to autoclaving.

In certain crosses the segregation of TBZ resistance was determined after growth of progeny on complex YPD plus TBZ $(50 \mu \mathrm{g} / \mathrm{ml})$. YPD, as used by Yamamoto (1980) was Yeast Extract $1 \%$; Peptone $2 \%$; Glucose 2\%, Agar $1.6 \%$.
Estimation of Cell Number and Optical Density. Optical density, related to culture dry mass content in $S$. pombe (Mitchison 1970 ), was estimated by measuring absorbance at $595 \mathrm{~nm}$ in a Pye Unicam SP 600 Spectrophotometer. Cell number was estimated by electronically counting a culture sample in a Coulter counter, model D with a $100 \mu \mathrm{m}$ orifice.

Cytology. Samples for light microscopy were filtered, heat fixed, extracted in $\mathrm{HCl}$ and stained with Giemsa (Lamb) according to the procedure of Nurse et al. (1976). Nuclei were examined and photographed using a $\times 63$ planapochromatic oil immersion objective on a Zeiss photomicroscope. Shrinkage in $S$. pombe cell length due to this fixation procedure is approximately $14 \%(\mathrm{~W}$. Haddow; personal communication).

\section{Results}

\section{Isolation of Benomyl Resistant Cold Sensitive Mutants}

Lawns of wild type $972 h^{-}$cells $\left(2-3 \times 10^{6}\right.$ cells per plate), from 5 clonal isolates, were spread on EMM2 plates containing $30 \mu \mathrm{g} / \mathrm{ml}$ of benomyl. These plates were then irradiated with U.V. light at a dose sufficient to cause $40 \%$ death.

150 benomyl resistant colonies were picked off the mutagenised plates after three days incubation at $35^{\circ} \mathrm{C}$. No benomyl resistant colonies were found on a control (non-irradiated) plate thus demonstrating the independent origin of the benomyl resistant mutants. The selected colonies were purified from background growth by further incubation on benomyl containing media at $35^{\circ} \mathrm{C}$.

The colonies were screened for cold sensitivity by examination of bulk growth after incubation on minimal medium for $2-3$ days at $20^{\circ} \mathrm{C}$. Mutants thought likely to carry a cell cycle mutation were identified by cell elongation. The rationale for this, originally used by Nurse et al. (1976) is that cellular growth continues during a division block (Mitchison and Creanor 1971; Fantes 1982). Approximately $25 \%$ of the 150 benomyl resistant mutants selected showed some degree of cellular elongation at $20^{\circ} \mathrm{C}$ compared to the wild type. On the basis of good elongation, seven mutants (A22, C10, C29, D2, D3, D19 and D23) were selected for further analysis.

\section{Genetic Analysis}

It was likely that the benomyl resistant and cold sensitive phenotypes observed in the mutants were the result of a single mutation in each case. Alternatively two or more separate mutations might have been involved to give this pleiotropic phenotype. To test this possibility the mutants were backcrossed to the wild type strain $975 h^{+}$. The asci were dissected and the resulting segregant colonies tested for growth and elongation on EMM2 containing benomyl at $35^{\circ} \mathrm{C}$ and EMM 2 alone at $20^{\circ} \mathrm{C}$. 
For the mutants C10, D2 and D3 backcrossed in this way the resulting tetrads showed co-segregation of benomyl resistance with cold sensitivity in a $2: 2$ mutant : wild type fashion, characteristic of a mutation in a single nuclear gene. At least 30 complete tetrads (4 viable spores) from each strain were analysed. It became apparent during backcrossing mutants A22, C29, D19 and D23 to the wild-type $975 h^{+}$that in each case a modifier mutation was segregating which affected both the benomyl resistant and cold sensitive phenotypes. Half the benomyl resistant, cold-sensitive segregants (Type I) showed a higher degree of drug resistance and cellular elongation at $20{ }^{\circ} \mathrm{C}$ than the rest (Type II). The original isolated mutants resembled Type II rather than Type I strains. Thus a tetratype tetrad from a typical cross between A22 and $975 h^{+}$contained 2 apparent wild-types: 1 Type I: 1 Type II, the two apparent wild-types being phenotypically indistinguishable. Type I progeny derived from each of the original isolates were backcrossed to wild-type strains of appropriate mating-type (at least 20 complete tetrads for each original isolate). Regular $2: 2$ Type I: wild-type segregations were always observed, irrespective of the mating type combination. In contrast, crosses between Type II segregants and wild-types showed segregation of Type I strains, in addition to wild-types and Type II progeny. These results show that the modifier mutation had in each case arisen during the isolation of the benomyl resistant mutant, and was not harboured unexpressed in either wild-type stock. In all further work modifier-free Type I segregants derived from A22, C29, D19 and D23 were used, rather than the original isolates. These modifier-free isolates behaved genetically in the same way as strains $\mathrm{C} 10, \mathrm{D} 2$ and D3, which were originally isolated as free of modifier genes.

Intercrosses between the modifier-free mutants were also analysed. C10 was crossed to the other six benomyl resistant mutants, and progeny tested for benomyl resistance and cold sensitivity. For each intercross combination involving $\mathrm{C} 10,10-20$ complete tetrads were analysed. No wild type (recombinant) segregants were found from any intercross involving $\mathrm{C} 10$, and this was also true for other intercrosses involving the remaining benomyl resistant mutants. This indicates very close linkage and very probably that the mutations are in a single genetic locus, designated ben 4 .

Reversion analysis was used to support the evidence from backcrossing that the benomyl resistant and cold sensitive phenotypes were the result of a mutation in a single gene. Of 32 spontaneous revertants from strain D3 that were able to form colonies at $20^{\circ} \mathrm{C}$ (albeit with different growth rates) all were more sensitive to benomyl at $35^{\circ} \mathrm{C}$ than the parental strain. Indeed, 4 of these revertants were indistinguishable from wild type cells as judged by cell length and growth at $20^{\circ} \mathrm{C}$ and sensitivity to benomyl at $35^{\circ} \mathrm{C}$.

\section{Dominance}

The dominance relationships of some mutant alleles for the benomyl resistance and cold sensitivity phenotypes were investigated in diploid strains.

Testing the benomyl resistance of diploids was complicated by the increased sensitivity of wild-type diploids compared with wild-type haploids. Wild-type diploids were completely inhibited by $20 \mu \mathrm{g} / \mathrm{ml}$ and showed considerable sensitivity to $10 \mu \mathrm{g} / \mathrm{ml}$ of the drug, while the wild-type haploid was unaffected by $10 \mu \mathrm{g} / \mathrm{ml}$, and completely inhibited only at $30 \mu \mathrm{g} / \mathrm{ml}$. The reasons for this are not clear. We therefore compared the benomyl resistance of diploids heterozygous at the ben 4 locus with the corresponding homozygotes. Diploids homozygous for ben4.D19 or ben4.D23 were able to form small colonies in the presence of $20 \mu \mathrm{g} / \mathrm{ml}$ benomyl after 3 days incubation at $35^{\circ} \mathrm{C}$, and rather larger colonies at $10 \mu \mathrm{g} / \mathrm{ml}$. The heterozygous diploids ben $4 / b^{+} n^{+}$showed a similar growth response, showing that the mutant alleles are dominant for benomyl resistance. In the case of ben 4.C10, the homozygous mutant showed considerable growth in the presence of $20 \mu \mathrm{g} / \mathrm{ml}$ benomyl, while the heterozygote ben $4 . \mathrm{C} 10 /$ ben $^{+}$was inhibited at this concentration, though it grew better than the wild-type diploid at $10 \mu \mathrm{g} / \mathrm{ml}$. The mutant allele is therefore semidominant for benomyl resistance.

Mutants ben4.D19 and ben4.D23, which show a strong cold-sensitive phenotype, were tested for dominance in homozygous and heterozygous diploids. The mutant homozygotes were unable to form colonies from $\mathrm{sin}$ gle cell inocula at $20^{\circ} \mathrm{C}$. The heterozygotes ben $4 /$ ben $^{+}$ did form colonies, though these were smaller than wildtype diploid colonies under the same conditions. In addition, the heterozygotes, when grown at $20^{\circ} \mathrm{C}$, formed cells intermediate in length between the wild-type diploid and the homozygous mutant diploids. These latter formed very elongated cells. The mutant alleles were therefore semidominant for cold-sensitivity.

\section{Linkage Tests}

Tetrad analysis showed that free recombination occurred between ben 4 and the following $c d c$ genes controlling steps before or in mitosis: $c d c 1,2,6,13,25,27$ and 28 (Nurse et al. 1976; Nasmyth and Nurse 1981; Fantes 1979). Free recombination also occurred between ben 4 mutants and the mitotic control mutant wee 1.6 (Thuriaux et al. 1978).

We tested the linkage relationships between our benomyl resistant mutants and the mutants (ben 1, 2 and 3) isolated by Yamamoto (1980) as resistant to thiabendazole (TBZ). Mutants ben4.C10 and ben4.D3 were crossed to representative alleles of ben 1,2 and 3. The 
Table 1. Growth and division of ben 4 mutants at 35 and $20^{\circ} \mathrm{C}$. Cultures growing exponentially at $35^{\circ} \mathrm{C}$ were shifted to $20^{\circ} \mathrm{C}$. Samples were taken at intervals to determine cell number $/ \mathrm{ml}$, culture turbidity and mean cell length. The parameters shown in the Table were estimated from the primary data: see Fig. 1 and text for explanation

\begin{tabular}{|c|c|c|c|c|c|c|}
\hline \multirow[t]{2}{*}{ Strain } & \multirow[t]{2}{*}{$\begin{array}{l}\text { Transition } \\
\text { point }\end{array}$} & \multirow{2}{*}{$\begin{array}{l}\text { Length } \\
\text { of plateau } \\
\text { in cell } \\
\text { number }(h)\end{array}$} & \multicolumn{2}{|c|}{$\begin{array}{l}\text { Mass (turbidity) } \\
\text { doubling time (h) }\end{array}$} & \multicolumn{2}{|c|}{ Mean cell length $(\mu \mathrm{m})$} \\
\hline & & & $35^{\circ} \mathrm{C}$ & $20^{\circ} \mathrm{C}$ & $35^{\circ} \mathrm{C}$ & $20^{\circ} \mathrm{C}(12 \mathrm{~h})$ \\
\hline 972 & - & - & 2.4 & 8 & 8.9 & 6.5 \\
\hline $\mathrm{A} 22$ & 0.8 & 7 & 4.0 & 13.5 & 8.8 & 15.5 \\
\hline $\mathrm{C} 10$ & 0.79 & 2 & 3.2 & 10 & 8.1 & 11.2 \\
\hline $\mathrm{C} 29$ & 0.85 & 7 & 4.2 & 13.5 & 9.3 & 15.7 \\
\hline D2 & 0.86 & 7 & 3.7 & 13.5 & 10.1 & 15.5 \\
\hline D3 & 0.78 & 6 & 3.7 & 14 & 9.8 & 16.4 \\
\hline D19 & 0.82 & 6 & 4.0 & 14 & 10.3 & 16.2 \\
\hline D23 & 0.75 & 6 & 4.0 & 13 & 8.9 & 14.5 \\
\hline
\end{tabular}

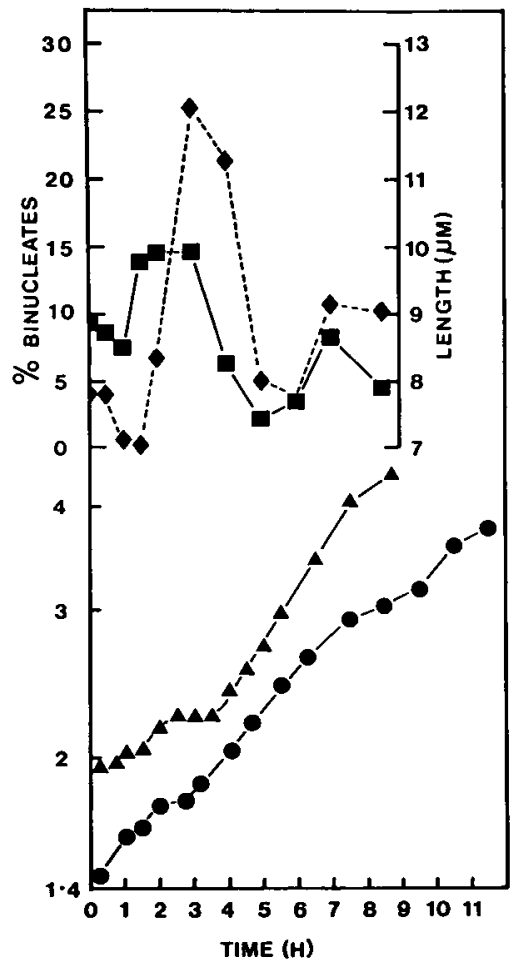

Fig. 1. Effect of temperature shift-down on strain 972. At time zero exponentially growing cells of strain 972 were transferred from 35 to $20^{\circ} \mathrm{C}$. Samples were taken for cell number $/ \mathrm{ml}(\Delta)$; turbidity $(\bullet)$; mean cell length in $\mu \mathrm{m}$ ( $\square$; mean of 50 cells); \% binucleate cells $(\diamond ; 300$ cells scored). Cell number $/ \mathrm{ml}$ and turbidity are shown on a logarithmic scale, 1 unit being equivalent to $10^{6}$ cells $/ \mathrm{ml}$ and 0.1 optical density unit

presence of a mutant ben 4 allele in segregants was ascertained by the elongation of cells at $20^{\circ} \mathrm{C}$, and in some cases by the resistance to benomyl at $35^{\circ} \mathrm{C}$. The presence of the mutant ben 1 allele was easily determined by the high degree of resistance to TBZ, with growth on YPD

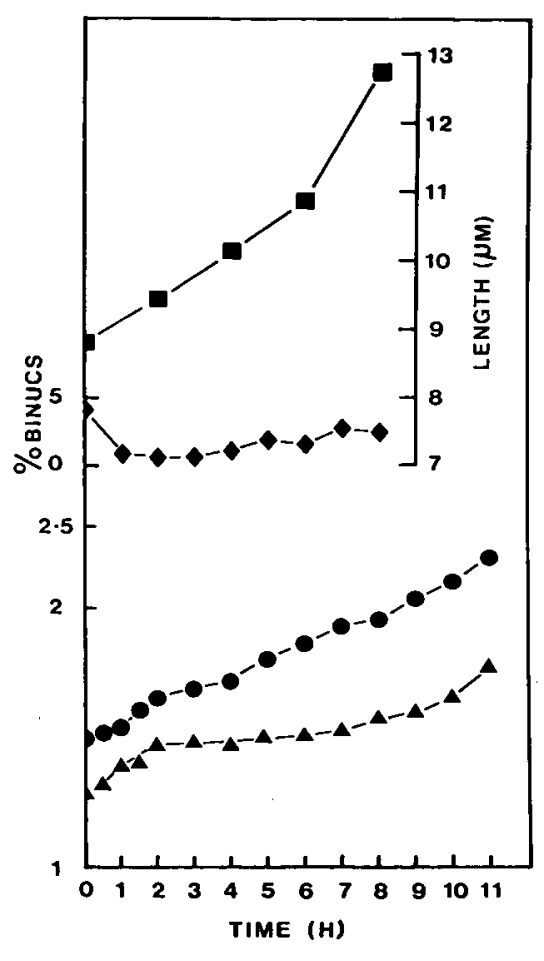

Fig. 2. Effect of temperature shift-down on strain ben4.D3. Conditions, symbols and scale as for Fig. 1

medium continuing at $50 \mu \mathrm{g} / \mathrm{ml}$ of the drug (Yamamoto 1980; our unpublished results). The ben 4 mutants, when grown on YPD, are sensitive to this concentration of TBZ (data not shown). All four possible progeny types were observed: the two parental types; wild-types showing normal sensitivity to benomyl and TBZ; and a double mutant class resistant to benomyl ( $30 \mu \mathrm{g} / \mathrm{ml}$ in EMM) and TBZ $\left(50 \mu \mathrm{g} / \mathrm{ml}\right.$ in YPD) at $35^{\circ} \mathrm{C}$, while exhibiting cold sensitivity at $20^{\circ} \mathrm{C}$. The presence of recombinant 
types among the progeny indicate that ben 1 and ben 4 are not closely linked ( 9 tetratype asci (TT): 1 parental ditype (PD): 1 non-parental ditype (NPD)). In crosses between ben 4 and either ben 2 or ben 3 strains, wild-type progeny segregated, identified by their sensitivity to benomyl (on EMM) and TBZ (on YPD), thus demonstrating a lack of close linkage between the genes (ben $4 \times$ ben 2 gave 7 TT: 0 PD: 0 NPD; ben $4 \times$ ben 3 gave 7 TT: 0 PD: 2 NPD). In these crosses, the low level of resistance to TBZ conferred by ben 2 and ben 3 (Yamamoto 1980; our unpublished results) made it difficult to unambiguously distinguish between ben 4 ben 2 and ben 4 ben $2^{+}$types, and between ben 4 ben 3 and ben 4 ben $3^{+}$ types. The presence of double mutants was sometimes inferred from the other spore colonies from the same tetrad.

These crosses show that the ben 4 locus is not closely linked to ben 1,2 or 3 .

\section{Physiological Characterisation}

In order to characterise further the physiological effect of cold-sensitive ben 4 mutations, cultures of wild-type and ben $4 . \mathrm{D} 3$ cells were monitored during growth at $35^{\circ} \mathrm{C}$ and after shift to $20^{\circ} \mathrm{C}$.

Growth and division of the benomyl resistant mutants at $35^{\circ} \mathrm{C}$ were essentially normal though the generation times were rather longer than that of the wild-type (Table 1). However the behaviour of wild-type and mutant strains was very different after shift to $20^{\circ} \mathrm{C}$ (Figs. 1 and 2 ). In the wild-type (Fig. 1), the rate of mass increase fell to a lower rate characteristic of the lower temperature shortly after the shift. The percentage of binucleate cells fell to zero for a period between 1 and $1 \frac{1}{2} \mathrm{~h}$ after shift. There followed a rapid increase in the fraction of binucleate cells, which remained high for about $3 \mathrm{~h}$. Thereafter the fraction of binucleates fell and showed no great variation. This behaviour was reminiscent of that shown by wild-type cells after other temperature shifts (Nurse et al. 1976). The first effect of the shift was to inhibit mitosis transiently, and this was followed by a short plateau in cell number between $2^{1} / 2$ and $3 \frac{1}{2} \mathrm{~h}$ after shift. The partially synchronous burst of mitosis was followed by a period of relatively rapid cell division. Mean cell length rose for a time after the shift, corresponding to a period when culture bulk growth was increasing faster than cell number. Cell length then fell sharply during the rapid rise in number, reflecting division running ahead of growth. Despite these fluctuations the overall rates of cell number and total mass increase were comparable.

Several major differences were apparent following a shift down of ben4.D3 cells (Fig. 2). The percentage of binucleate cells fell to zero within one hour, and re- mained below $2 \%$ for at least $8 \mathrm{~h}$ after shift. After a small increase in cell number, cell division ceased and a plateau in cell number ensued which lasted several hours. This behaviour was in complete contrast to that of wildtype cells: no synchronous wave of mitosis nor subsequent rise in cell number was observed. Mean cell length increased throughout the experiment, consistent with the observed increase in culture mass while cell division was blocked (Fig. 2).

These results, taken together, indicated that ben4.D3 showed a cold sensitive defect in cell cycle progress, though not in growth. The accumulation of cells at the uninucleate stage was consistent with the cycle defect preventing mitosis. This was supported by the transition point of the mutant at 0.78 in the cycle, calculated from the fraction of cells exhibiting residual division after shift, which is consistent with the time of mitosis itself in the wild-type. Most of the other ben 4 mutants tested showed very similar patterns of growth and division to ben4.D3 (Table 1). The only exception was ben4.C10 which showed a much less pronounced block in mitosis and cell division (Table 1). This mutant was retained largely for genetic analysis, since it crossed more readily than the other mutants.

\section{Drug Resistance}

The benomyl resistant mutants were tested for cross resistance to the microtubule agents TBZ and CIPC. Growth of mutant and wild type strains was tested on solid EMM2 containing various concentrations of TBZ, CIPC or benomyl at $35{ }^{\circ} \mathrm{C}$. Growth was scored on a semiquantitative basis and the results are presented in Table 2 . Growth of wild type cells was inhibited by a concen. tration of benomyl of $30 \mu \mathrm{g} / \mathrm{ml}$ whereas the benomyl resistant mutants were able to grow on the maximum concentration tested of $100 \mu \mathrm{g} / \mathrm{ml}$. A concentration of TBZ of at least $60 \mu \mathrm{g} / \mathrm{ml}$ was necessary to inhibit wild type growth. The mutant $\mathrm{C} 10$ showed a very slightly increased resistance to TBZ. This was in contrast to the remaining six benomyl resistant mutants which were slightly more sensitive to TBZ than the wild type. Wild type and C10 cells grown on CIPC were inhibited completely by $100 \mu \mathrm{g} / \mathrm{ml}$ of the drug, though showing substantial growth at $60 \mu \mathrm{g} / \mathrm{ml}$. Interestingly, the other benomyl resistant mutants were more sensitive to CIPC, growth being completely inhibited by $60 \mu \mathrm{g} / \mathrm{ml}$.

\section{Cytological Observations}

Samples of cultures incubated at 35 and $20^{\circ} \mathrm{C}$ were taken for light microscope examination. The normal interphase nucleus of $S$. pombe is visualised as a crescent 
Table 2. Growth of ben 4 strains in the presence of microtubule agents. Growth of the strains was tested on solid minimal medium containing the inhibitors at the concentrations shown $(\mu \mathrm{g} / \mathrm{ml})$. Cultures were incubated at $35^{\circ} \mathrm{C}$ and growth scored after 3 days, on a scale from 0 (no growth) to +++ (maximal)

\begin{tabular}{|c|c|c|c|c|c|c|c|c|c|c|c|c|c|}
\hline \multirow[t]{2}{*}{ Strain } & \multicolumn{5}{|c|}{ Benomyl } & \multicolumn{4}{|l|}{ TBZ } & \multicolumn{4}{|c|}{ CIPC } \\
\hline & 0 & 10 & 30 & 60 & 100 & 10 & 30 & 60 & 100 & 10 & 30 & 60 & 100 \\
\hline 972 & +++ & +++ & 0 & 0 & 0 & +++ & +++ & 0 & 0 & +++ & +++ & ++ & 0 \\
\hline $\mathrm{C} 10$ & +++ & +++ & +++ & ++ & ++ & +++ & +++ & + & 0 & +++ & $+t+$ & ++ & 0 \\
\hline 6 other ben 4 mutants & +++ & +++ & ++ & ++ & ++ & +++ & ++ & 0 & 0 & $+t$ & ++ & 0 & 0 \\
\hline
\end{tabular}

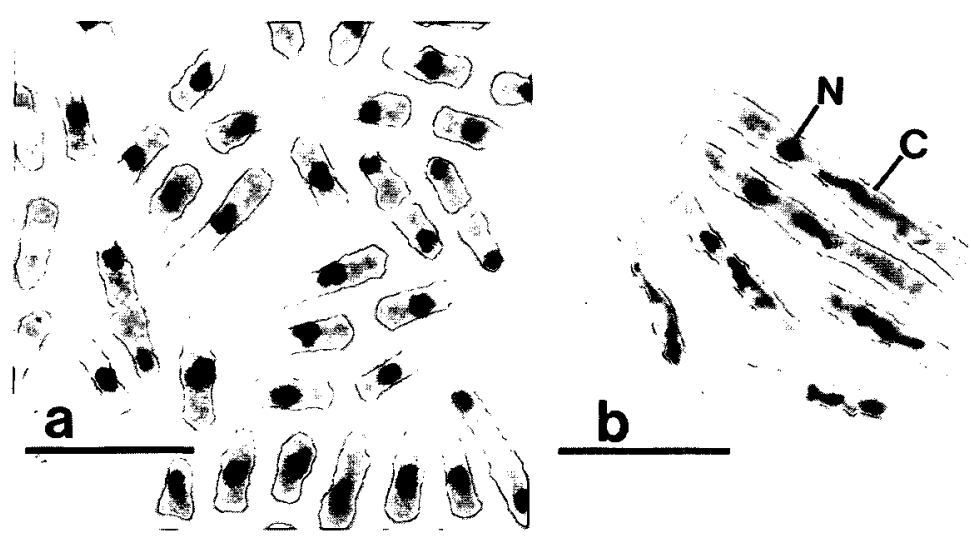

Fig. 3a and b. Nuclear morphology of wildtype and ben $4 . \mathrm{D} 3$ cells following growth at $35^{\circ} \mathrm{C}$ and $12 \mathrm{~h}$ incubation at $20^{\circ} \mathrm{C}$; a Light micrograph of Giemsa stained wild-type cells, showing normal nuclear morphology; b Light micrograph of Giemsa stained ben 4.D3 cells, showing elongated cells and aberrant nuclear morphology. $\mathrm{N}$-nucleolus; C-chromatin; scale bar $=10 \mu \mathrm{m}$ of chromatin adjacent to a spherical nucleolus (McCully and Robinow 1971; Fig. 3a). Giemsa stained preparations reveal the nucleolus as reddish-purple, and the chromatin as bluish-purple under the conditions used, allowing the two components to be distinguished. Cells and nuclei of ben 4 grown at $35^{\circ} \mathrm{C}$ appeared very similar to wild-types grown at 35 or $20^{\circ} \mathrm{C}$. The nuclear morphology of the ben 4 mutants (except ben4.C10, which showed an incomplete cell cycle arrest) after growth at $20^{\circ} \mathrm{C}$ was very different (Fig. 3b). Strain D3 was grown at $35{ }^{\circ} \mathrm{C}$, shifted to $20^{\circ} \mathrm{C}$ for $12 \mathrm{~h}$, and the cells were Giemsa stained. The nucleus was substantially elongated, with the nucleolus near one end and the chromatin strung out along the length of the nucleus (Fig. 3b).

\section{Discussion}

This sudy shows that in $S$. pombe single mutations in the ben 4 locus may simultaneously confer benomyl resistance and a cold sensitive phenotye. The defect prevents the completion of mitosis and may be within the mitotic machinery itself, as shown by the behaviour of cells following shift to the restrictive temperature, in particular the aberrant nuclear morphology. Our selection scheme was designed to obtain mutants with the dual benomyl resistant and cold-sensitive phenotype, so many strains exhibiting only the former were discarded.
One mutant retained, $\mathrm{C} 10$, showed a much weaker cold sensitive phenotype than the other six analysed, although the degree of benomyl resistance was very similar for all seven mutants. It is therefore likely that ben $4 \mathrm{mu}-$ tants not simultaneously cold-sensitive for mitosis could be obtained. However the observation that mutants with both phenotypes can be obtained leads us to suggest that the ben 4 gene may code for $\beta$-tubulin. In support of this proposal we offer the following lines of evidence: (1) Genetical analysis shows that both benomyl resistance and cold sensitivity for mitosis are due to a single mutation in each case. The observed phenotype suggests that the ben 4 function is modified rather than lost in our mutants. This is supported by the dominance or semidominance of ben 4 mutations over ben ${ }^{+}$in diploids heterozygous at the ben 4 locus. The range of possible candidates for the ben 4 gene product is limited to proteins which interact, directly or indirectly, with the antimicrotubule agent benomyl, and which are concerned with the process of mitosis. (2) Six of the seven mutants examined show increased sensitivity to another known microtubule agent, CIPC. This again implicates a tubulin or related component of the mitotic machinery. (3) There is a striking similarity between the behaviour of ben $4 \mathrm{mu}-$ tants and certain mutants of the related ascomycetes Aspergillus nidulans and Saccharomyces cerevisiae. In $A$. nidulans some benomyl resistant mutants mapping at the benA locus are also heat sensitive for mitosis 
(Oakley 1981). The ben A gene has been shown to code for $\beta$-tubulin by direct examination of the protein produced by wild-type and benA mutants (Sheir-Neiss et al. 1978). In Saccharomyces cerevisiae, benomyl resistant, temperature sensitive mutants have been obtained, some of which are complemented by a plasmid carrying a yeast DNA sequence homologous to a cloned chick $\beta$-tubulin gene (Neff et al. 1981).

We believe, on the basis of the above evidence, that the ben 4 gene in $S$. pombe codes for $\beta$-tubulin, and experiments to test this directly are in progress.

Yamamoto (1980) isolated a number of mutants of $S$. pombe resistant to the antimicrotubule agent TBZ, which mapped at three loci, ben 1,2 and 3 . Genetic analysis demonstrates that the mutants we isolated map at a different locus, designated ben 4 . On the basis of their high degree of resistance to several antimitotic drugs and dominance relationships, ben 1 mutants were suggested by Yamamoto (1980) to be defective in a tubulin. We cannot comment on this possibility at present, and it may be that ben 1 and ben 4 both code for different tubulins or other related proteins. It is perhaps surprising that no ben 4 mutants were obtained by Yamamoto among a total of 16 isolated as TBZ resistant. It may be relevant that the ben 4 mutants described here do not show significant cross resistance to $\mathrm{TBZ}$, though the phenotypic range of ben 4 mutants examined is too narrow to draw general conclusions about patterns of cross resistance: other ben 4 mutants might well be resistant to TBZ.

The aberrant nuclear morphology shown by six of the seven ben 4 mutants after incubation at $20^{\circ} \mathrm{C}$ is indicative of a disorganised mitosis. The terminal position of the nucleolus within the elongated nucleus is abnormal, and may reflect the diversion of the developmental process from its normal path. Such arrangements are not seen in the course of mitosis in the wild-type (McCully and Robinow 1971).

Among other mutants of $S$. pombe defective in mitosis, none of the cold-sensitive mutants described by Toda and co-workers (1981) show elongated nuclei. Nor have heat-sensitive mutants of mitosis been described which show both an elongated nucleus and a terminally positioned nucleolus. However the former characteristic has been reported for $c d c 1.7$ (King and Hyams 1982) and the latter for strain ED22 (Nurse et al. 1976) and perhaps for $c d c 25.22$ (derived from ED22; Fantes 1979) and other $c d c 25$ mutants (King and Hyams 1982). Further cytological studies with cold-sensitive ben 4 mutants should prove informative about the molecular basis of mitosis, and identification of the ben 4 gene product will assist in this.

Acknowledgements. We are grateful to Dr. M. Yamamoto for supplying strains for genetical analysis. We also thank Murdoch Mitchison for helpful discussions and reading of the manuscript.
The support of an M.R.C. research studentship to D. R. is gratefully acknowledged.

\section{References}

Egel R (1973) Mol Gen Genet 121:277-284

Fantes PA (1979) Nature 279:428-430

Fantes PA (1982) J Cell Sci 55:383-402

Frankel J, Jenkins LM, DeBault LE (1976) J Cell Biol 71:242260

Gutz H, Heslot H, Leupold U, Loprieno N (1974) Schizosaccharomyces pombe. In: King RC (ed) Handbook of Genetics vol 1. Plenum Press, New York, pp 395-445

Hartwell LH (1978) J Cell Biol 77:627-637

Howell S (1974) An analysis of cell cycle controls in temperature sensitive mutants of Chlamydomonas reinhardii. In: Padilla GM, Cameron IL, Zimmerman A (eds) Cell cycle controls. Academic press, New York, pp 235-249

Inoué S, Sato H (1967) J Gen Physiol 50:259-292

Jarvik J, Botstein D (1973) Proc Natl Acad Sci USA 70:20462050

King SM, Hyams J (1982) Protoplasma 110:54 -62

Leupold U (1950) CR Lab Carlsberg Ser Physiol 24:381 -480

McCully EK, Robinow CF (1971) J. Cell Sci. 9:475-507

Mitchison JM (1970) Physiological and cytological methods for S. pombe. In: Prescott DM (ed) Methods in cell physiology, vol. 4. Academic Press, New York, pp 131-165

Mitchison JM, Creanor J (1971) Expl Cell Res 67:368-374

Moir D, Stewart S, Botstein D (1978) Abstracts, 9th International Conference on Yeast Genetics and Molecular Biology, Rochester, New York, p 69

Morris NR (1980) Chromosome structure and the molecular biology of mitosis in eukaryotic micro-organisms. In Gooday GW, Lloyd D, Trinci APJ (eds) The Eukaryotic Microbial Cell. University Press, Cambridge, pp 41-76

Nasmyth K, Nurse P (1981) Mol Gen Genet 182:119-124

Neff N, Thomas JH, Botstein D (1981) In: Molecular Biology of Yeast. Cold Spring Harbour Symposium, p 246

Nurse P (1975) Nature 256:547-551

Nurs̀e P (1981) Genetic Analysis of the Cell Cycle. In: Glover SW, Hopwood DA (eds) Genetics as a Tool in Microbiology. University Press, Cambridge, pp 291-315

Nurse P, Thuriaux P, Nasmyth K (1976) Mol Gen Genet 146: $167-178$

Oakley BR (1981) Mitotic Mutants. In: Cellular Dynamics: Mitosis/Cytokinesis. Academic Press, New York, pp 181-196

Peterson EL, Berger JD (1976) Can J Zool 54:2089-2097

Quinlan RA, Pogson CI, Gull K (1980) J Cell Sci 46:341-352

Roth LE (1967) J Cell Biol 34:47-59

Sheir-Neiss G, Lai MH, Morris NR (1978) Cell 15:638-647

Simchen G (1978) Ann Rev Genet 12:161-191

Thuriaux P, Nurse P, Carter B (1978) Mol Gen Genet 161:215220

Toda T, Yamamoto M, Yanagida M (1981) J Cell Sci 52:271287

Walker GM (1982) J Gen Microbiol 128:61-71

Weisenberg RC (1972) Science 177:1104-1105

Yamamoto M (1980) Mol Gen Genet 180:231-234

Communicated by B. Cox

Received July 1, 1982 